\begin{abstract}
UNIVERSIDADE DE SÃO PAULO
PROGRAMA DE PÓS-GRADUAÇÃO EM CIÊNCIA AMBIENTAL
\end{abstract}

RENATA DE SOUZA LEÃO MARTINS

EMPRESAS E GESTÃo DA ÁGUA: UMA ABORDAGEM A PARTIR DO USO DO INDICADOR PEGADA HÍDRICA

\author{
SÃO PAULO \\ 2014
}


RENATA DE SOUZA LEÃO MARTINS

\section{EMPRESAS E GESTÃO DA ÁGUA: UMA ABORDAGEM A PARTIR DO USO DO INDICADOR PEGADA HÍDRICA}

Tese apresentada ao Programa de PósGraduação em Ciência Ambiental (PROCAM) da Universidade de São Paulo para obtenção do título de Doutora em Ciência Ambiental.

Orientador: Prof. Dr. Pedro Roberto Jacobi

\section{Versão Corrigida}

(versão original disponível na Biblioteca que aloja o Programa e na Biblioteca Digital de Teses e Dissertações da USP)

SÃO PAULO 
AUTORIZO A REPRODUÇÃO E DIVULGAÇÃO TOTAL OU PARCIAL DESTE TRABALHO, POR QUALQUER MEIO CONVENCIONAL OU ELETRÔNICO, PARA FINS DE ESTUDO E PESQUISA, DESDE QUE CITADA A FONTE.

FICHA CATALOGRÁFICA

Martins, Renata de Souza Leão.

Empresas e gestão da água: uma abordagem a partir do uso do indicador pegada hídrica../ Renata de Souza Leão Martins; orientador : Pedro Roberto Jacobi. - São Paulo, 2014.

178f.: il.; $30 \mathrm{~cm}$.

Tese (Doutorado - Programa de Pós-Graduação em Ciência Ambiental ) - Universidade de São Paulo

1. Recursos hídricos. 2. Planejamento de recursos hídricosaspectos sociopolíticos . 3. Pegada Hídrica. 4. Consumo de água. I. Título. 
FOLHA DE APROVAÇÃO

Renata de Souza Leão Martins

Empresas e gestão da água: uma abordagem a partir do uso do indicador Pegada Hídrica

Data da Aprovação ___ _ _

Banca Examinadora

Nome/Instituição

Assinatura

Nome/Instituição

Assinatura

Nome/Instituição

Assinatura

Nome/Instituição

Assinatura

Nome/Instituição

Assinatura 


\section{AGRADECIMENTOS}

A conclusão deste trabalho é repleta de significados para mim, tanto profissionalmente como também, e talvez mais ainda, pessoalmente.

Enquanto pensava no que escrever e para quem escrever, relembrei desses quatro anos de jornada. E me dei conta de que os percursos são mais importantes do que os destinos.

Durante esses anos tive a sorte de ter muita gente querida compartilhando tudo o que vem junto com um doutorado.

Agradeço ao meu orientador Prof. Pedro Jacobi, pela amizade, pelo apoio e pelas oportunidades de trabalhar em vários projetos e aprender tantas coisas.

Aos meus queridos amigos do PROCAM Carol, Natalia, Paulo, Felipe, Nicolas, Mariana, Marcelo, Luizi, Vinicius e Lidiane, pela amizade, viagens, risadas. Pelo fundamental apoio, torcida e carinho nestes últimos meses. Por não terem fugido de mim!!!

Agradeço também à professora Ana Paula Fracalanza pelas valiosas contribuições feitas na qualificação. Obrigada outra vez à Prof Ana Paula e ao Prof. Gerardo Kuntischik por todo o apoio, conversas e interesse pelas minhas dúvidas e minhas histórias. Aos professores Paulo Sinisgalli, Luiz Carlos Beduschi e Eduardo Caldas, pelas ricas discussões nas disciplinas. Tenho uma lista de pós-doutorados para fazer.

Aos colegas do grupo do Prof. Alberto Garrido, da Universidad Politecnica de Madrid. Em especial a Barbara Willaarts.

Ao José Gomes Ferreira, colega do Instituto de Ciências Sociais da Universidade de Lisboa, pela atenção, paciência e ensinamentos sobre Modernização Ecológica.

Agradeço muito ao Prof. Alexandre Igari, pelo tempo, gentileza, disposição e conversas que tivemos na reta final do doutrado.

À minha família, pelo suporte e afeto. Agradeço especialmente à minha mãe, porque sim, pela sua generosidade e amor. À minha madrinha, pela amizade, carinho e por estar por perto. Ao meu avô pela doçura com a qual me olha e sorri. E pela sua sabedoria e grandiosidade. À Mirella por me fazer rir. Ao Panda pela companhia nos dias/noites intermináveis.

Ao Rafael por me lembrar com frequência de que era preciso ter calma. À Lili pelo carinho. À Débora pela boa energia e nossas conversas. Ao Dê pelo apoio incondicional e pelo carinho ao me ouvir repetidamente, por anos e anos.

Agradeço também à Begoña, Florian, David, Javi, Vir e Olivia pelo carinho com o qual me receberam e pelas frequentes palavras de incentivo.

Ao Dani, por tudo. Tudo mesmo. Pela revisão do texto. Por mais de um ano de conversas sobre a tese, sobre Pegada Hídrica. Inúmeras delas por skype, com diferença de 5 horas na maior parte das vezes. Agradeço sua paciência e cuidado. Por não ter desistido de mim um minuto.

Agradeço também ao Programa de Pós Graduação em Ciência Ambiental do Instituto de Energia e Ambiente da Universidade de São Paulo. Aos secretários Luciano e Julia, pela colaboração e atenção.

À CAPES, pela bolsa concedida. 


\title{
RESUMO
}

\author{
Martins, Renata de Souza Leão. Empresas e gestão da água: uma abordagem a partir do \\ uso do indicador Pegada Hídrica. Tese (Doutorado) - Programa de Pós-Graduação em \\ Ciência Ambiental (PROCAM), Universidade de São Paulo, São Paulo, 2014.
}

Nos últimos anos, as questões relacionadas à problemática ambiental multiplicaram sua presença na agenda do setor empresarial. Mais recentemente, observa-se o aumento do interesse das empresas pela água, recurso natural indispensável para a manutenção do equilíbrio dos ecossistemas e das atividades socioeconômicas humanas. Diante da ampliação da pressão sobre seu uso, resultado do crescimento populacional e incremento dos padrões atuais de produção e consumo, diferentes ferramentas têm sido desenvolvidas para contribuir para que o uso da água se torne mais racional e sustentável. Uma delas é a Pegada Hídrica $(\mathrm{PH})$, um indicador de consumo direto e indireto da água utilizada durante a produção de bens ou serviços. A PH está relacionada com a pressão causada aos recursos hídricos pelas atividades humanas e classifica a água usada nesses processos e atividades de acordo com sua origem e impacto. Sua utilização pelo setor empresarial tem sido cada vez mais frequente. Tendo como base este contexto, este trabalho busca compreender quais são os principais motivos que tem levado as empresas a utilizarem a PH. Esta Tese, de caráter interdisciplinar, utiliza como referenciais teóricos a Teoria da Modernização Ecológica (TME), a Teoria dos Stakeholders (TS) e elementos da Nova Sociologia Econômica (NSE). Para alcançar o objetivo proposto, foram utilizados três procedimentos metodológicos: a) levantamento documental; b) revisão bibliográfica sistemática; c) estudos de caso. Os motivos que justificam a utilização da PH extraídos dos documentos analisados na revisão bibliográfica sistemática foram sistematizados e agrupados em quatro categorias que podem ser relacionadas com os referenciais teóricos utilizados. Os resultados obtidos na pesquisa indicaram que os motivos que têm levado as empresas a utilizarem a Pegada Hídrica são: 1) vantagens do método, já que permite uma visão detalhada do consumo de água em toda a cadeia produtiva (TME); 2) comunicação com stakeholders, pois reconhecem que é necessário avaliar o consumo da água em toda a sua cadeia, para atender as demandas dos diferentes stakeholders internos e externos e melhorar sua comunicação com eles (TS; NSE); 3) porque a PH pode colaborar na identificação de riscos associados à água, o que permite agir com certa antecipação a futuras regulações e contestações dos diferentes stakeholders (NSE); 4) porque os resultados dos estudos de PH podem fornecer informações que colabore na tomada de decisão para reduzir o consumo de água, estabelecer parcerias e cooperação entre os diferentes setores da sociedade (TME). Entre os motivos apontados, os mais frequentes são aqueles relacionados com as "vantagens do método", o que permite uma compreensão mais ampla da pressão e impactos à água causados pelas atividades das empresas. Entretanto, considerando que sua utilização pelo setor empresarial é muito recente, pesquisas futuras necessitam ser realizadas para acompanhar a evolução das ações e do comportamento das empresas sobre a temática da água. Nesse sentido, torna-se cada vez mais urgente uma reflexão sobre a necessidade de que os limites físicos existentes e a capacidade de suporte dos ecossistemas orientem a organização das sociedades.

Palavras-chave: Pegada Hídrica, empresas; consumo de água; atores socioambientais 


\begin{abstract}
Martins, Renata de Souza Leão. Corporation and Water Management: an approach based on the use of Water Footprint. Tese (Doutorado) - Programa de Pós-Graduação em Ciência Ambiental (PROCAM), Universidade de São Paulo, São Paulo, 2014.
\end{abstract}

In recent years, several environmental issues have multiplied their presence in the corporate sector's agenda. More recently, an increased interest is observed among companies on the topic of water, an essential natural resource for the maintenance of ecosystems equilibrium and human socio-economic activities. To face the increasing pressure over the resource, resulting from the combination of population growth and changing consumption patterns, several tools have been developed. Their goal is to make corporate water consumption more rational and sustainable. One of these tools is the Water Footprint (WF), an indicator of direct and indirect water consumption in the production of goods and services. The water footprint quantifies and assesses the pressure from human activities on water resources. It classifies water resources according to their source and potential impact. Its use by the private sector is increasingly frequent. Against this context, this work aims at understanding the main reasons for companies' adoption of the WF Assessment. This thesis, embracing a multidisciplinary approach, makes use of three theoretical frameworks: the Ecological Modernization Theory (EMT), Stakeholder theory (ST) and elements of the New Economic Sociology (NES). To this end, three different methodologies where used: a) document research; b) systematic literature research; c) case studies. The stated reasons for using the WF found in the literature research where classified into four categories that may be related to the theoretical frameworks presented. The results from this research identified as the main reasons under private sector's adoption of the WF. The first reason could be called advantages of this methodology, since it allows for a detailed analysis of water consumption in the supply chain, which can be analyzed using the EMT. A second reason would be related to the communication with the stakeholders. Companies recognize the need for addressing water consumption over their whole supply chain in order to meet the demands of different stakeholders and improve their communications with them. This recognition is explained by the ST and NES. Thirdly, risk assessment was is another important argument. WF assessment may help to address water-related risks, allowing them to anticipate the introduction of new regulations or contestation from different stakeholders. NES allows us to understand this reason. Lastly, companies include informed decisionmaking as another adoption reason. WF may be used for establishing goals and priorities for lower water consumption rates, identifying key partners and working together with key sectors of society. Ecological modernization theory contributes to explain this effect. The most frequent reasons mentioned were those related to the advantages of the methodology, arguing that the WF provides a broader understanding of pressure resulting from corporate activities. Nevertheless, considering the recent adoption by the private sector of this method, it would be important to re-evaluate the relation between water and the private sector, and with the WF in particular. In this sense, it is increasingly necessary that environmental limits and ecosystems carrying capacity guide societal organization.

Key-Words: Water Footprint, corporations; water consumption; stakeholder 


\section{LISTA DE TABELAS E QUADROS}

Tabela1. Resultado da revisão bibliográfica sistemática. 104

Quadro 1. Classificação das iniciativas para gestão da água no setor empresarial..

Quadro 2. Categorias dos motivos que justificam a utilização da Pegada Hídrica. (n)

Quadro 3. Motivos da utilização da Pegada Hídrica extraídos dos documentos analisados (antes da categorização). 


\section{LISTA DE FIGURAS}

Figura 1. Esquema dos componentes de uma Pegada Hídrica.............................................51

Figura 2. Fases que compõe a avaliação da Pegada Hídrica..................................................52

Figura 3. - Esquema que representa os procedimentos metodológicos utilizados em relação à aproximação do objeto de estudo.

Figura 4. Fases da revisão bibliográfica sistematizada adotada nesta pesquisa.

Figura 5. Exemplos de respostas extraídas dos documentos analisados por categoria criada.

Figura 6. - Relação entre os referenciais teóricos e categorias que justificam a utilização da $\mathrm{PH}$ pelo setor empresarial

Figura 7. Linha do tempo dos principais eventos internacionais sobre água e meio ambiente

Figura 8. Distribuição do universo amostral inicial levantado nas duas plataformas (Water Footprint Network - WFN e Web of Science) e do total analisado, por ano de publicação....104

Figura 9. Classificação das informações extraídas dos documentos analisados sobre a utilização da PH por empresas.

Figura 10. Número de artigos por categoria de argumento apresentado "antes da realização do estudo de PH" e "depois da realização do estudo de PH" 


\section{LISTA DE ABREVIATURAS E SIGLAS}

ABTCP - Associação Brasileira Técnica de Celulose e Papel

ACV - Avaliação de ciclo de vida

ANA - Agência Nacional de Águas

AWS - Alliance for Water Stewardship

CDP - Carbon Disclusure Project

DJSI - Dow Jones Sustainability Index

EPA - Environmental Protection Agency

EUA - Estados Unidos de América

EWS - European Water Stewardship

FSC - Forest Stewardship Council

FUSP - Fundação Universidade de São Paulo

GLAAS - Global Analysis and Assessment of Sanitation and Drinking-Water

GRI - Global Reporting Initiative

GWP - Global Water Partnership

IDA - Índice de Desempenho Ambiental

IPPC - Painel Intergovernamental sobre Mudanças Climáticas

ISE - Índice de Sustentabilidade Empresarial

ISO - International Organization for Standardization

IWRA - International Water Resources Association

IWRM - Gestão integrada dos recursos hídricos

JMP - Joint Monitoring Programme for Water Supply and Sanitation

NSE - Nova Sociologia Econômica

ODM - Objetivos de Desenvolvimento do Milênio

OMS - Organização Mundial da Saúde

ONGs - organizações não governamentais

ONU - Organização das Nações Unidas

PH - Pegada Hídrica

PNUD - Programa das Nações Unidas para o Desenvolvimento

PNUMA - Programa das Nações Unidas para o Meio Ambiente

RBS - Revisão bibliográfica sistemática

RSC - Responsabilidade Social Corporativa 
TME - Teoria da Modernização Ecológica

TNC - The Nature Conservancy

TS - Teoria dos Stakeholders

UNESCO - Organização das Nações Unidas para a Educação, a Ciência e a Cultura

UNICEF - Fundo das Nações Unidas para a Infância

WBCSD - World Business Council for Sustainable Development

WWF - World Wildlife Fund

WSSCC - Conselho Colaborativo para o Abastecimento de Água e o Saneamento

WWC - World Water Council

WWDR - World Water Development Report 


\section{SUMÁRIO}

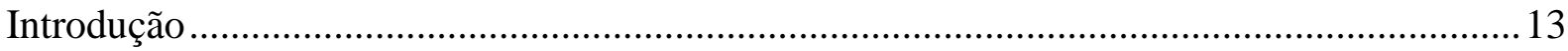

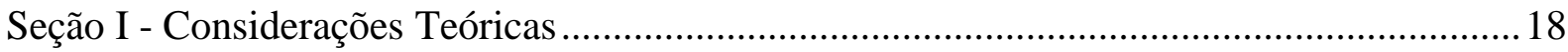

Capítulo 1. Empresas e Meio Ambiente: a emergência do tema......................................... 19

Capítulo 2 - Empresas e Meio Ambiente: a conciliação? ................................................... 24

2.1 A Perspectiva da Teoria da Modernização Ecológica ............................................... 24

2.2. Empresas e sociedade: a influência dos diferentes stakeholders na questão ambiental 28

Capítulo 3. Empresas e água: a construção do problema ................................................... 33

Capítulo 4. Empresas e água: a formulação de respostas ................................................... 40

Capitulo 5. Pegada Hídrica: aspectos conceituais e metodológicos ................................... 49

5.1. Pegada Hídrica - Principais aplicações em âmbito internacional ...............................54

5.2. Pegada Hídrica - A experiência nacional ............................................................... 60

5.3 Principais reflexões críticas acerca da Pegada Hídrica .............................................62

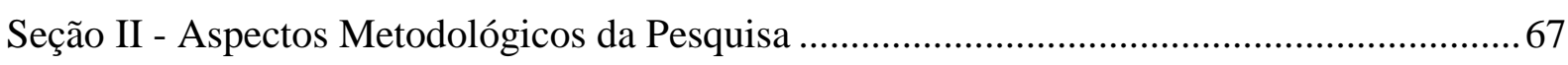

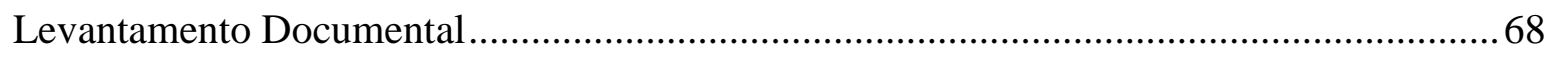

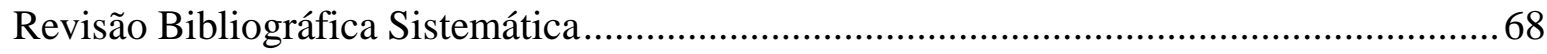

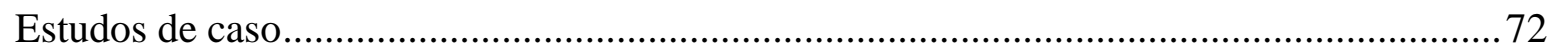

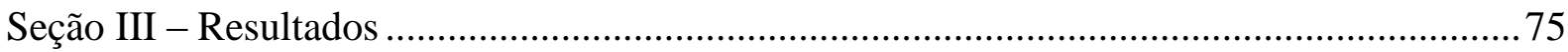

Capítulo 6. A água na agenda global- Uma Linha do Tempo .......................................... 76

6.1. O histórico da agenda global da água sob a perspectiva da modernização ecológica

Capítulo 7 Por que usar a Pegada Hídrica nas Empresas? Uma proposta de sistematização dos motivos encontrados na revisão bibliográfica sistemática ........................................ 103

7.1. Análise e discussão dos resultados da revisão bibliográfica sistemática................. 109

7.2. Análise das categorias definidas na revisão bibliográfica sistemática .....................111

Capitulo 8 - A aplicação da Avaliação da Pegada Hídrica por duas grandes empresas

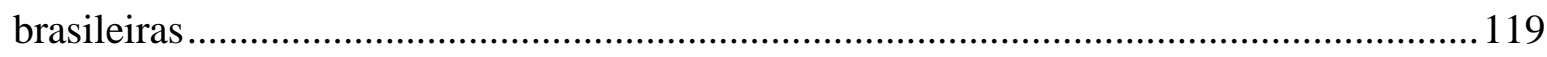

8.1. Natura e Fibria: caracterização das empresas estudadas ....................................... 119

8.2. Estudos de Caso: a Pegada Hídrica na Natura e na Fibria ...................................... 121

8.2. Síntese Analítica dos Casos Estudados ................................................................ 136

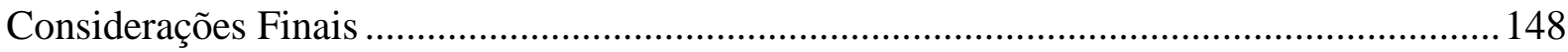

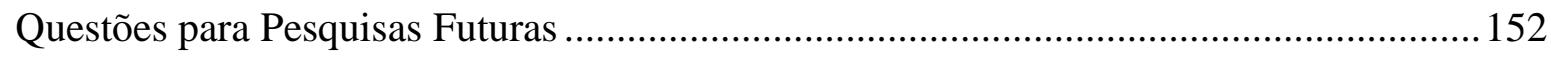




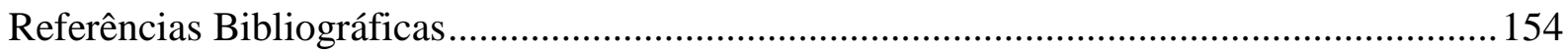

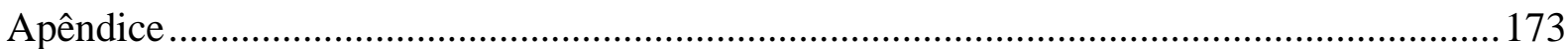




\section{Introdução}

As questões relacionadas à problemática ambiental têm presença crescente na agenda das corporações. Seja por meio da adoção de tecnologias mais eficientes no uso dos recursos naturais e no controle da poluição, pelo monitoramento das etapas do processo produtivo, pelas novas relações com os stakeholders e divulgação do seu desempenho ambiental. Isto se observa na medida em que as empresas estão mudando o modo de lidar com essas questões, institucionalizando de diferentes maneiras e com diferentes nuances a racionalidade ecológica (GONÇALVES-DIAS; TEODÓSIO, 2011; ABRAMOVAY, 2012).

Dentre os diferentes temas ambientais, as questões relacionadas à água têm sido discutidas na agenda internacional desde a década de 1960, principalmente em eventos realizados pela Organização das Nações Unidas (ONU). Na segunda metade dos anos 1990 novos arranjos internacionais emergem, e o setor empresarial passa a ser um ator com participação cada vez mais ativa nas discussões sobre água, apoiando diversas iniciativas.

Gradativamente, observa-se que as questões relacionadas à água são mais abordadas pelas empresas, que reconhecem que a água é um recurso fundamental para a manutenção de suas atividades.

O atual padrão de produção e consumo que marca as sociedades contemporâneas, em virtude das demandas planetárias crescentes por alimentos e bens de consumo, agrava a pressão causada sobre a água. A situação torna-se mais complexa quando consideradas também as mudanças climáticas globais, que podem alterar os regimes de chuva e impactar negativamente a disponibilidade hídrica para atender todos os usos em diversas regiões.

O aumento da produção de bens de consumo e de alimentos pode causar impactos negativos à água principalmente por duas razões. Em primeiro lugar, pelo aumento dos volumes de água captados e, portanto, sua direta interferência na disponibilidade hídrica nas bacias hidrográficas. E em segundo lugar, pela contaminação da água, causada pelo lançamento pontual e difuso de efluentes oriundos de atividades industriais e agrícolas. Dependendo do alcance desses impactos negativos, conflitos pelo acesso e uso da água podem emergir, além de aumentar casos de injustiça ambiental causados a grupos em condições socioeconômicas vulneráveis (ACSELRAD et al., 2009). 
Estudos recentes apontam que algumas regiões do mundo apresentam quadros de vulnerabilidade hídrica onde, pelo menos uma vez ao ano, o consumo de água ultrapassa o volume de água disponível, afetando até dois bilhões de pessoas (HOESKTRA et al., 2012; HOESKTRA; WIEDMANN, 2014).

O cenário de incertezas em relação às questões hídricas indica que nos últimos anos a temática envolvendo a água tem se tornado tão relevante, que tem estado inclusive nas discussões do Fórum Econômico Mundial. Na edição de 2014, a problemática em torno da água foi considerada a terceira mais importante entre os dez riscos globais identificados em pesquisa, disponível no relatório Global Risks 2014 ${ }^{1}$. Daniel e Sojamo (2012) apontam que os impactos econômicos associados às questões de disponibilidade hídrica tendem a crescer e podem alcançar centenas de bilhões de dólares.

Diante de um cenário cada vez mais complexo, a emergência de riscos associados à água é inevitável. As empresas, por estarem inseridas na sociedade (ABRAMOVAY, 2012), também estão expostas a uma diversidade de riscos que são compartilhados entre todos os usuários.

Morrison et al. (2010) aponta que os principais riscos com relação à água que uma empresa pode enfrentar são os riscos físicos, riscos regulatórios, riscos reputacionais e financeiros.

Os riscos físicos estão relacionados à disponibilidade hídrica para a manutenção das atividades da empresa. Os riscos regulatórios estão relacionados com alterações realizadas pelo órgão responsável, como por exemplo, mudança nas condições de outorgas e alteração da legislação do lançamento de efluentes.

Ainda, as empresas podem estar expostas a riscos reputacionais quando os impactos de suas atividades afetam negativamente as comunidades de entorno, a paisagem e também os ecossistemas aquáticos. Já os riscos financeiros estão relacionados com os outros riscos e ocorrem, por exemplo, com o aumento de custos com tratamento da água, aumento dos valores cobrados pelo seu uso e perdas de investidores e consumidores por danos à imagem e reputação da empresa.

\footnotetext{
${ }^{1}$ O relatório está disponível na página na Internet do World Economic Forum http://reports.weforum.org/globalrisks-2014/part-1-global-risks-2014-understanding-systemic-risks-in-a-changing-global-environment/
} 
Alguns autores entendem que, apesar de limitado, as empresas podem exercer um importante papel para atuar em direção ao uso responsável da água. Nesse sentido, argumentam que melhorar a gestão interna de uso da água pode trazer benefícios desde a redução de custos pelo pagamento pela água até a antecipação a futuras regulações (HEPWORTH, 2012; LARSON et al., 2012; LANBOOY, 2011).

A partir da reflexão sobre o papel das empresas como agentes capazes de auxiliar a enfrentar os crescentes desafios associados à água, nos últimos anos diferentes ferramentas e iniciativas têm sido desenvolvidas para auxiliar as empresas abordarem a temática da água. Dentre as diversas ferramentas disponíveis, a Pegada Hídrica $(\mathrm{PH})$ merece destaque, pois tem sido aplicada em estudos diversos publicados em revistas científicas internacionais.

Desenvolvida a partir do conceito de água virtual, a Pegada Hídrica é um indicador de consumo direto e indireto de água, que considera todas as fases da produção de um bem ou serviço. Além disso, seu método contabiliza a água consumida de acordo com sua origem e impacto, classificando-a em PH verde, PH azul e PH cinza. A PH azul é a quantidade de água consumida de origem superficial ou subterrânea. A PH verde é definida como a quantidade de precipitação que é armazenada no solo e que é consumida pelas plantas. E, por fim, a PH cinza, que, por se tratar de um indicador de impactos sobre a qualidade da água, é definida como a quantidade de água necessária para diluir os poluentes presentes no efluente resultante do processo produtivo em questão (HOEKSTRA et al., 2011).

O conceito de Pegada Hídrica foi elaborado a partir da perspectiva da água consumida pelas atividades humanas, permitindo analisar, portanto, a pressão causada aos sistemas hídricos pelos modos de produção e consumo. É possível aplicar o método em estudos com diferentes propósitos e escalas, como em bacias hidrográficas, países, produtos e empresas (CHAPAGAIN; TICKNER, 2012).

Observa-se que desde a criação da rede Water Footprint Network em 2008, organização responsável por aprimorar e divulgar o conceito, o método tem despertando interesse de empresas multinacionais e nacionais de diferentes setores para utilizá-la em seus processos produtivos.

Diante deste contexto, este trabalho tem como objetivo compreender quais são os motivos que têm levado as empresas a optarem pela utilização da Pegada Hídrica em seus processos produtivos. 
A pergunta de pesquisa que norteia a tese se centra nas razões que estimulam empresas a adotar o método da Pegada Hídrica quando existem outras opções. De maneira mais objetiva "Por que as empresas têm utilizado a Pegada Hídrica?" seria a pergunta orientadora desta investigação.

A justificativa para a realização desta pesquisa está baseada na ideia de que a identificação e análise dos fatores que motivam o engajamento das empresas sobre as questões relacionadas à água, neste caso a partir da adoção da $\mathrm{PH}$, pode enriquecer o debate sobre a complexidade da internalização dos desafios sobre a relação entre empresas e água, que emergiu recentemente. Além disso, a identificação das respostas motivadoras contribui para a reflexão sobre os caminhos possíveis que as empresas têm sinalizado para atuarem no sentido do uso sustentável da água. Isso poderá a direcionar os esforços no desenvolvimento de ferramentas que pretendam aproximar as empresas de questões relacionadas à água e estimular a parceria e cooperação entre diferentes setores, como o setor público, ONGs e cidadãos. Por tratar-se de uma temática recente, esta pesquisa tem caráter inédito.

A hipótese desta Tese é que as empresas que têm adotado a Pegada Hídrica o fazem porque consideram que estão expostas, de forma crescente, aos diversos riscos associados à água - riscos físicos, regulatórios, reputacionais e financeiros.

Para alcançar o objetivo proposto e confirmar ou refutar a hipótese inicial desta tese, foram utilizados três procedimentos metodológicos que estão detalhadamente descritos na Seção II desta tese.

Em linhas gerais, o primeiro procedimento foi um levantamento documental com a finalidade de identificar quando ocorre a inserção do setor empresarial nas discussões internacionais sobre água e em qual contexto se deu a inserção. O segundo procedimento metodológico consistiu numa revisão bibliográfica sistemática realizada em duas plataformas de busca, Web of Science e Water Footprint Network, que reúne uma diversidade de artigos científicos e relatórios sobre a utilização da PH. Nos documentos selecionados foram identificados os motivos que justificavam a utilização da Pegada Hídrica para, em seguida, serem categorizados de acordo a semelhança das respostas. Por fim, foram realizados estudos de caso com duas empresas brasileiras que utilizaram a PH, com objetivo de compreender os motivos que as levaram a utilizar a PH. 
A sequência metodológica adotada neste trabalho analisa o objeto de estudo inicialmente por uma perspectiva global (levantamento documental) em direção a uma abordagem mais específica e detalhada (revisão bibliográfica sistemática e estudos de caso). Considerando o caráter interdisciplinar desta tese, a finalidade foi de compreender a relação entre empresas e a temática da água por meio de referenciais teóricos de disciplinas diferentes. Assim, utilizamos a Teoria da Modernização Ecológica, corrente da Sociologia Ambiental, a Teoria dos Stakeholders, literatura da Administração de Empresas e ainda elementos presentes na abordagem da Nova Sociologia Econômica.

Como poderá ser observado nas próximas páginas, ao utilizar diferentes disciplinas para subsidiar as discussões, resultado desta pesquisa, acreditamos que, além de enriquecer a análise e o debate, uma complementa a outra na interpretação e discussão sobre como o setor empresarial pode lidar com as questões ambientais.

Esta tese está organizada em três seções. Na Seção I são apresentadas as considerações teóricas, composta de cinco capítulos. Na Seção II são descritos os três procedimentos metodológicos utilizados neste trabalho. E finalmente, na Seção III se apresenta os resultados, organizados em três capítulos- linha do tempo, revisão bibliográfica sistemática e estudos de caso.

Nas considerações finais apresenta-se uma síntese analítica dos principais resultados e se faz uma indicação quanto à necessidade de trabalhos futuros, a partir de questões que emergiram durante o desenvolvimento desta pesquisa. 


\section{Seção I - Considerações Teóricas}

Esta primeira parte da tese é composta de cinco capítulos nos quais abordam a relação entre as empresas e a questão ambiental. O desenho delineado para desenvolver esta temática foi elaborado partindo do ponto mais geral em direção aos temas mais específicos.

Deste modo, discorreremos no primeiro capítulo sobre os fatores que têm contribuído para que a problemática ambiental passe a ser tratada pelo setor empresarial. No segundo capítulo, apresentaremos os referenciais teóricos que foram utilizados para apoiar a argumentação em torno do nosso objeto de pesquisa, a utilização da $\mathrm{PH}$ pelo setor empresarial.

No terceiro capítulo, abordaremos a questão principal da tese: a relação entre as empresas e a água partindo da construção da problemática sobre as questões relacionadas à água para o setor empresarial. No quarto capítulo serão apresentadas as ferramentas e iniciativas que têm sido desenvolvidas por diferentes instituições para que as empresas estejam melhores preparadas para enfrentar estes novos desafios.

Finalmente, no quinto capítulo, apresentamos os aspectos conceituais e metodológicos sobre a Pegada Hídrica, e em seguida discorremos sobre as principais aplicações do método em diferentes escalas, em âmbito internacional e nacional. Para concluir o capítulo, são apresentadas as principais reflexões críticas sobre a Pegada Hídrica. 


\section{Capítulo 1. Empresas e Meio Ambiente: a emergência do tema}

O problema da degradação ambiental é interpretado de maneira geral como uma intrínseca ou automática consequência das dinâmicas sociais das sociedades industrializadas do século XX (BUTTEL, 2003).

O debate sobre até onde iria a responsabilidade do setor corporativo em relação às esferas que estavam fora das empresas é marcado por discussões acadêmicas nos anos que antecedem a década de 70 (CARROLL, 1979) em uma época em que havia uma forte corrente de pensamento que argumentava que a única responsabilidade e interesse que uma empresa deveria ter era aumentar o lucro de seus acionistas e sócios. Porém, apesar de majoritárias nas escolas de negócio, a noção de responsabilidade social corporativa (RSC) foi sendo construída ao longo do tempo ${ }^{2}$ (FRIEDMAN, 1970).

Durante a década de 60 a discussão se centrava no conceito de RSC, no seu caráter voluntário e nas suas obrigações em relação a assuntos que iam além das funções econômicas das organizações (CARROLL, 1979; CARROL; SHABANA, 2010).

Mesmo assim, algumas empresas tentavam melhorar a vida de seus trabalhadores ou de sua comunidade de entorno tendo como marca um caráter filantrópico (CARROLL, 1999). Nesta época, de maneira geral, a regulação ambiental não era nem uma preocupação e tampouco uma necessidade, dando às empresas certa liberdade e autonomia para resolver qualquer questão em relação ao meio ambiente (HOFFMAN, 1997).

A partir dos anos 70 e até o início da década de 1980, é que o setor corporativo passa a ser mais controlado e até questionado, principalmente nos países industrializados. Isso ocorre, por um lado, por meio de processos de regulação ambiental por parte dos governos, com a elaboração de leis ambientais e criação de agências de fiscalização e controle ambiental. E por outro lado, pela ação dos movimentos sociais ambientalistas e pelo enfrentamento de algumas ONGs internacionais às grandes corporações responsáveis por causar grandes impactos socioambientais negativos (HOFFMAN, 1997).

\footnotetext{
${ }^{2}$ Existem diferentes definições para RSC que variam de acordo com o entendimento que uma empresa tem de suas responsabilidades e pode compreender questões econômicas, sociais, éticas e ambientais, por exemplo. Moon (2007) argumenta que a essência da RSC deve ser contribuir para o bem-estar socioambiental. Ver mais sobre RSC em: Carrol, 1979; 1999; Moon, 2007.
} 
Esse maior controle governamental e social foi impulsionado com a publicação do livro Primavera Silenciosa, de Rachel Carlson em 1962, e também com os vários incidentes de repercussão internacional que ocorreram, como o de Minamata (Japão) em 1956, o caso de Love Canal em 1978 nos Estados Unidos, o caso da indústria em Bhopal na Índia em 1984, a explosão do reator nuclear em Chernobyl, na Ucrânia (1986) e ainda o derramamento de petróleo pelo Exxon Valdez no Ártico (1989). A partir destes incidentes, grandes corporações tentam recuperar ou manter sua reputação e legitimidade por meio de estratégias focadas em RSC (FARIA; SAUERBRONN, 2008).

No entanto, é na metade da década de 1980 que emerge a ideia do ambientalismo como responsabilidade social corporativa. Nota-se que há uma aproximação do movimento ambientalista com o setor industrial, fazendo com que este último estabeleça algumas normas em relação às questões ambientais como sinal de sua responsabilidade social. Assim, inicia-se uma prática que em seguida se tornará fundamental no cotidiano das organizações (HOFFMAN, 2000).

A partir daí nota-se um destaque no papel dos grupos ambientalistas que passam a influenciar mais diretamente as estratégias ambientais das empresas, pois além do crescimento do número de membros das organizações não governamentais (ONGs), percebese também uma especialização dos temas ambientais tratados por elas, além da profissionalização nas atividades desempenhadas por estas ONGs (GONÇALVES-DIAS; TEODÓSIO, 2011).

Nesse sentido, em termos gerais, parte do movimento ambientalista passa a atuar de modo menos radical, em direção a um comportamento cooperativo, inclusive desenvolvendo alianças e parcerias com grandes empresas de modo a influenciar outras empresas menores e com menor poder, principalmente nos países onde mais se avançou na reforma ambiental (MOL, 2000).

É possível observar, portanto, que até este momento, o setor corporativo respondia ao Estado, por meio da legislação ambiental, ou à sociedade civil, por meio da pressão do movimento ambiental. E de acordo com Hoffman (2000), estas duas forças tem sido as que mais influenciam as empresas a adotarem práticas voltadas à questão ambiental.

Moon (2007) acrescenta que além dos governos e dos movimentos sociais, o mercado e a globalização também agem como uma força que impulsiona a institucionalização da 
racionalidade ecológica nas empresas. Vários vetores presentes no mercado têm contribuído para o fortalecimento da responsabilidade social corporativa, como consumidores, empregados, investidores, fornecedores e clientes.

Ainda, a globalização também tem servido para fortalecer o papel da RSC, principalmente em empresas que atuam em mais de um país, o que faz com que muitas adotem o Global Report Initiative (GRI) como modelo para desenvolverem e publicarem seus relatórios anuais de sustentabilidade. Coletivamente, a RSC tem avançado, por exemplo, com o surgimento do United Nation Global Compact (MOON, 2007), iniciativa de estratégia política para as empresas alinharem suas operações com princípios mundiais de direitos humanos, trabalho, meio ambiente e anticorrupção.

A atitude voluntária do setor corporativo em adotar práticas e ferramentas com objetivo de diminuir a degradação ambiental passa a ser institucionalizada no final dos anos 80 e início dos 90. De acordo com Hoffman (1997), é nesse período que as questões ambientais passam a ser estratégicas para as empresas e é neste contexto que os departamentos de meio ambiente, ou aqueles relacionados a ele, são criados.

Essa institucionalização das práticas voltadas às questões ambientais resulta, por exemplo, na implementação de sistemas de gestão ambiental, criação de departamentos e setores ambientais dentro das organizações, ou ainda normas e certificações de RSC, permitindo também a participação das empresas nas arenas políticas. Ou seja, a organização de empresas de um mesmo setor ou em torno de uma questão comum, na forma de associações e redes, se torna estratégica, pois pode facilitar sua participação nos espaços deliberativos e decisórios, além de poderem influenciar ou mesmo patrocinar a elaboração de normas e políticas (FARIA; SAUERBRONN, 2008).

Deste modo, a globalização dos mercados, junto com a os avanços das tecnologias de informação e comunicação, e a organização social na forma de redes têm contribuído para que o setor empresarial desenvolva estratégias para se relacionar e lidar com questões que antes não faziam parte de seus negócios (ABRAMOVAY, 2012).

No Brasil, a responsabilidade social corporativa vai obtendo mais espaço principalmente desde a criação do Instituto Ethos, em 1997. Porém, apesar do avanço das discussões sobre o tema, torna-se necessário maior aprofundamento analítico e crítico das 
práticas de RSC no país, para evitar a transposição acrítica de abordagens de RSC estrangeiras, principalmente americanas (FARIA; SAUERBRONN, 2008).

Esse novo papel que as empresas começam a desempenhar é resultado tanto do reconhecimento da interdependência entre sociedade e natureza como do amadurecimento e da alteração de valores que parte da sociedade desenvolve com o passar dos anos, tornando-se mais consciente dos efeitos negativos que a degradação ambiental causa na vida das pessoas.

Isso se reflete também na mudança dos temas que vão sendo enfrentados pelos diferentes atores interessados pela problemática ambiental.

Por exemplo, há alguns anos em muitos países, os assuntos debatidos eram a adoção de técnicas de controle e tratamento de efluentes industriais (DONAIRE, 1994) e tinham um caráter local. Atualmente, os temas discutidos principalmente são de interesse e efeitos regionais e globais, como desmatamento, obtenção de energia, poluição da água, emissões atmosféricas, efeitos das mudanças climáticas e escassez de recursos naturais para a produção de bens e serviços (BANERJEE, 2002; GAN et al.; 2013; HOEKSTRA, 2014).

Isso reforça a análise feita por Hoffman (1997) sobre o ambientalismo corporativo, de que a emergência da questão ambiental dentro das empresas vai sendo construída entre os atores que disputam seus interesses nas arenas públicas externas às organizações. Nesse sentido, destaca-se o papel dos movimentos sociais, dos consumidores, dos governos e também daquelas empresas que ao alterar suas práticas podem influenciar mudanças na tomada de decisões dentro do quadro organizacional.

O desenrolar da relação entre setor privado e meio ambiente contradiz as ideias de Milton Friedman em texto publicado na New York Times Magazine sobre a questão ambiental e o setor corporativo em 1970. Segundo ele, "qualquer empresa que investisse recursos financeiros em controle da poluição para além do que era exigido pela legislação, praticaria o mais puro socialismo"3 (FRIEDMAN, 1970).

Friedman defende ainda que a função principal das empresas é gerar lucros para seus acionistas e que a contribuição para a sociedade já é feita através do pagamento de impostos e geração de empregos. Considera ainda que uma organização não pode ser responsabilizada, como se fosse um cidadão. A responsabilidade da empresa a respeito de um passivo ambiental

\footnotetext{
${ }^{3}$ Tradução nossa.
} 
é limitada financeiramente ao montante de capital social de cada acionista (FRIEDMAN, 1970).

O curioso é que o que viria ocorrer nas décadas seguintes em termos de responsabilidade ambiental corporativa se tornaria a essência da prática de puro capitalismo, uma vez que as questões ambientais passam a ser estratégicas para as empresas (HOFFMAN, 1997). Nesse sentido, um fator que ganha atenção ao impulsionar as práticas de incorporar as questões ambientais na agenda das empresas é a oportunidade de aumentar os resultados financeiros.

E apesar da lógica economicista, a RSC passa a ser vista também como oportunidade competitiva para empresas, onde a inovação contribui tanto para alimentar a competitividade, como para evitar que as empresas sejam prejudicadas pela legislação ambiental, por meio de regulações (PORTER; LINDE, 1995).

Deste modo, uma das implicações estratégicas do ambientalismo empresarial pode ser a migração de ações do tipo end-of-pipe 4 para medidas preventivas de monitoramento e controle de impactos socioambientais, aumentando a capacidade das empresas de obterem vantagens competitivas (BANERJEE, 2002).

Tomando como ponto de partida as ideias propostas por Friedman, sintetizadas na frase "Business of business is business", podemos sugerir que a incorporação da racionalidade ecológica por parte das empresas é uma resposta dada às demandas e questionamentos feitos pela sociedade, como apresentado a seguir.

\footnotetext{
${ }^{4}$ Ações que não visam atuar na redução da emissão de poluentes.
} 


\section{Capítulo 2 - Empresas e Meio Ambiente: a conciliação?}

No contexto que permeia a relação entre a temática socioambiental e as empresas, emergem questões como, por exemplo, sobre o papel dos agentes econômicos na conservação dos recursos naturais, ou ainda sobre como as questões discutidas externamente ao ambiente empresarial podem permear e comporem a agenda das corporações. Nesse sentido, para discutir e refletir sobre a emergência da questão ambiental na agenda empresarial, a relação entre empresas e a questão ambiental será abordada nesta tese a partir da combinação de ideias presentes em diferentes disciplinas, todas de origem sociológica, que serão frequentemente resgatadas durante todo o trabalho. O trabalho mobilizará, portanto, as ideias centrais da Teoria da Modernização Ecológica, corrente da Sociologia Ambiental, além de elementos presentes na Nova Sociologia Econômica, e também da literatura da Administração, por meio da Teoria dos Stakeholders, como serão apresentadas nos dois subcapítulos a seguir.

\subsection{A Perspectiva da Teoria da Modernização Ecológica}

No final dos anos 80 e especialmente na década de 90 a sociologia ambiental começa a estudar o que Buttel (2003) chama de reforma ambiental, por meio da redefinição das relações entre Estado, sociedade e agentes econômicos. Segundo ele, a problemática da sociologia ambiental migra de uma problemática que explica a causa da degradação ambiental para a aquela que explica a reforma ambiental, ou seja, as melhorias e avanços nas condições ambientais.

Uma das correntes teóricas presentes na sociologia ambiental é a modernização ecológica, que tem sido considerada como uma das mais fortes perspectivas que pretende compreender e interpretar como as sociedades industrializadas enfrentam as questões ambientais (MOL, 2000; TOKE; STRACHAN, 2006).

Em termos históricos, o termo Modernização Ecológica aparece pela primeira vez essencialmente como um programa político, em 1982 em Berlin ${ }^{5}$, a partir da necessidade de trazer as questões ecológicas para discussão, influenciando o debate político alemão no

\footnotetext{
${ }^{5}$ Mol e Sonnenfeld (2000) atribuem ao sociólogo alemão Joseph Huber o desenvolvimento da teoria da Modernização Ecológica.
} 
sentido de aproximar a ecologia e a economia. Nessa época, a tentativa era de que a ciência e a academia contribuíssem com uma reforma ambiental que melhorassem as condições ambientais, usando a noção de modernização ecológica como uma ideia prática e normativa. A proposta tinha como estratégia o uso eficiente dos recursos naturais trazendo benefícios tanto para o ambiente como para a economia (MOL; JÄNICKE, 2000).

Nesta mesma época, pequenos grupos de pesquisa em sociologia ambiental localizados principalmente na Alemanha, Holanda e Reino Unido começaram a contribuir com a Teoria da Modernização Ecológica (TME). Os autores que mais se envolveram no debate sobre a TME são Martin Jänicke, Gert Spaargaren, Martin Hajer, Artul Mol, Albert Weale, na Europa, e Frederick Buttel, nos Estados Unidos (MOL; SONNENFELD, 2000; MOL, 2010).

Neste primeiro momento, a ênfase da TME era nas inovações tecnológicas industriais e na visão otimista do papel das dinâmicas de mercado como os agentes principais no combate à degradação ambiental (MOL; SPAARGAREN, 2009).

Por esta razão, a TME recebe muitas críticas devido ao seu determinismo tecnológico, sua orientação produtivista e a negligência ao abordar temas como consumo e poder, e ainda por enfocar países industrializados (YORK; ROSA, 2003; CAROLAN, 2004). Portanto, seu caráter técnico é a causa de maior parte das críticas, já que propõe que os problemas criados pela expansão industrial podem ser solucionados com novas tecnologias e uso eficiente dos recursos naturais (FISHER; FREUDENBURG, 2001).

Ao mesmo tempo, outros tipos de críticas direcionadas à abordagem da TME têm sido feitas por autores de diferentes paradigmas e correntes teóricas, como os neomarxistas, que não acreditam que a ordem capitalista permita nenhuma reforma "além da fachada" (SCHNAIBERG et al., 2000) e que não é possível um "capitalismo sustentável" (O’CONNOR, 1994). Ou ainda para os adeptos da ecologia profunda, que defendem a necessidade de uma reforma fundamental e radical da ordem moderna. Nesse sentido a característica reformista da TME como forma de obter crescimento econômico e conservação da natureza é constantemente questionada por autores de outras abordagens teóricas.

Entretanto, um dos principais autores da TME, Arthur Mol (2010), argumenta que apesar da insistência de alguns autores sobre estes temas, a abordagem da modernização 
ecológica amadureceu, atenuou seu caráter tecnicista e tem incorporado novos aspectos à teoria.

Assim, a partir da década de 1990, a tecnologia e o papel do mercado, agentes principais da reforma ambiental preconizados pela TME no seu início, perdem um pouco sua força e no lugar amplia-se o debate sobre a relação entre Estado e mercado. Nesse sentido, basicamente foram desenvolvidas duas principais reflexões sobre essa relação.

Primeiramente, de acordo com a TME, os atores econômicos (por exemplo, produtores, consumidores e instituições financeiras) podem agir positivamente conservando os recursos naturais, contrariando a visão dos movimentos ambientais da década de 1970 e 1980, que os interpretavam como os principais destruidores do equilíbrio ambiental (MOL; JÄNICKE, 2000).

Em segundo lugar, a TME considera que o Estado tem um papel fundamental na manutenção e conservação dos recursos naturais. Entretanto, é necessária uma reestruturação na sua forma de atuação em relação às questões ambientais, na direção de se tornar uma instituição mais flexível, descentralizada e preventiva, atuando em redes com outros atores sociais, aplicando diferentes instrumentos, de modo a guiar a sociedade a modos mais sustentáveis de comportamento. Essa mudança é preferida ao modo burocrático, hierárquico, reativo e aos mecanismos de comando-controle comumente usado pelo Estado em tratamento e enfrentamento da problemática ambiental (MOL; JÄNICKE, 2000).

Isso, tendo em vista que as estratégias de comando-controle utilizadas pelo Estado não tem demonstrado eficácia no controle da degradação ambiental, apesar de serem importantes e necessárias. Nesse sentido, os teóricos da modernização ecológica acreditam que a participação de atores que representam outros grupos de interesse na política ambiental em novos arranjos e espaços, podem melhorar os processos de governança, complementando a regulação feita pelos governos (ER et al., 2012).

Assim, com o tempo, outras formas de organizações e temas passam a ser consideradas pela perspectiva da TME, além das inovações tecnológicas. Por exemplo, o deslocamento dos Estados-Nações e os novos arranjos e espaços de governança, descentralizados, flexíveis e participativos para elaboração e discussão das políticas ambientais (MOL; SONNENFELD, 2000). 
Além disso, a internalização da racionalidade ecológica pelas empresas na tentativa de conciliar a questão ambiental e o seu desempenho econômico, seja pela ação do mercado, regulação governamental ou movimentos sociais, é um bom exemplo do que é preconizado pela TME em uma vertente mais ampla (BUTTEL, 2003; MOL, 2010).

Deste modo, a partir da incorporação destes temas à TME, alguns autores passam a distinguir e classificar a modernização ecológica em fraca, baseada em estratégias técnicocorporativistas, e em modernização ecológica forte, onde se torna reflexiva abrindo espaço para aprendizagem e novos arranjos institucionais (CHRITSOFF, 1996; MOL; SPAARGAREN, 2000).

Em outras palavras, uma visão mais restrita da TME responde de maneira mais convencional à problemática ambiental, solicitando somente ajustes incrementais às políticas ambientais. Por outro lado, para permitir uma transformação social no âmbito da modernização ecológica forte é necessário o fortalecimento do debate público e entre diferentes interlocutores, especialistas e não especialistas (MEMON et al., 2011).

Nesse sentido, a modernização ecológica forte se aproxima, por exemplo, do conceito de governança ambiental que, apesar de diferentes significados e aplicações, geralmente se baseia na multiplicidade de atores participantes, como governos, sociedade civil e empresas, em processos descentralizados de tomada decisão em torno de um tema socioambiental comum (JACOBI; SINISGALLI, 2012).

É importante destacar que um dos aspectos pouco discutidos em relação à teoria da modernização ecológica está na sua orientação voltada às mudanças nos sistemas produtivos, por meio da adoção de melhores práticas e ecoeficiência, quando deveria abordar também a problemática do consumo (CAROLAN, 2004).

Deste modo, ainda que a TME contribua para a emancipação da racionalidade ecológica, o debate sobre as implicações da manutenção da lógica de produção infinita, resultado da ideia de crescimento econômico ilimitado não é amplamente realizado pela sociedade (SOUZA LEÃO et al., 2014). Assim, torna-se necessário que seja realizada uma reflexão pela perspectiva dos limites dos sistemas ecológicos para que respostas alternativas ao modo de produção e consumo atuais possam emergir coletivamente, de modo que considere outras questões além de crescimento econômico, como desenvolvimento, equidade no acesso aos recursos e justiça socioambiental, por exemplo. 
Apesar das limitações apresentadas acima, a escolha da Teoria da Modernização Ecológica como um dos referenciais teóricos utilizados nesta Tese justifica-se, em primeiro lugar, por ser uma das correntes teóricas presentes na sociologia ambiental que apresenta uma perspectiva que aborda simultaneamente como se dá a emancipação da racionalidade ecológica pelos diferentes setores e atores sociais. Em segundo lugar, porque considera que as empresas, ao internalizarem a racionalidade ecológica, podem contribuir para a melhoria das condições ambientais. Portanto, considera-se que sua utilização neste trabalho contribuirá, em um primeiro momento, para compreender como se dá a aproximação das empresas nas discussões internacionais em relação à água. Em um segundo momento, contribuirá para responder à pergunta de pesquisa desta Tese e identificar qual pode ser a contribuição da utilização da PH pelo setor empresarial nas questões associadas à água.

\subsection{Empresas e sociedade: a influência dos diferentes stakeholders na questão ambiental}

De acordo com a abordagem proposta pela Teoria dos Stakeholders (TS), existe o reconhecimento de que todas as partes interessadas e envolvidas com as atividades da empresa são capazes de influenciar a tomada de decisão no âmbito organizacional (PHILLIPS et al., 2003; FREEMAN; LIEDTKA, 1991). Nesse sentido, esta abordagem se baseia na relação de interdependência entre as empresas e a sociedade (FARIA; SAUERBRONN, 2008).

A Teoria dos Stakeholders é proposta por Freeman no ano de 1984, ganhando com o passar do tempo uma literatura vasta e diversificada. Seu foco principal é a democratização da relação entre sociedade e empresas contrapondo a ideia de que a única função das organizações é atender os interesses de seus acionistas (FARIA; SAUERBRONN, 2008).

Freeman (1984) define o termo stakeholder como qualquer grupo ou indivíduo que afeta ou é afetado pelo alcance das atividades da empresa. Esta perspectiva tem sido considerada uma das possíveis formas de trazer a problemática ambiental para ser abordada dentro das empresas (FARIA; SAUERBRONN, 2008; BANERJEE, 2002).

Neste trabalho, utilizaremos as ideias da TS, tendo ciência de que a teoria possui muitos outros aspectos voltados à gestão organizacional, porém que não fazem parte do escopo da pesquisa que resulta nesta tese. 
A ideia central da TS é que além dos acionistas e sócios, existem outros atores interessados nas atividades da empresa, como por exemplo, trabalhadores, consumidores, fornecedores, competidores, comunidades locais, governos, entre outros. Por esta razão, as empresas devem atender de modo equilibrado a todos esses interesses e prestar-lhes contas de suas atividades (FREEMAN; LIEDTKA, 1991).

Além disso, é preciso considerar que a avaliação das empresas somente pelo aspecto econômico é insuficiente para analisar os custos repassados à sociedade, surgindo a necessidade de as empresas serem avaliadas também pelo seu desempenho socioambiental, uma vez que suas atividades geram impactos negativos, muitas vezes compartilhados com os cidadãos que residem ou trabalham no local (BANERJEE, 2002).

Portanto, a necessidade de comunicação e prestação de contas do desempenho socioambiental aos diferentes stakeholders são as ideias centrais que serão frequentemente resgatadas na análise dos resultados obtidos nesta pesquisa.

Desta forma, cada vez mais é discutida a necessidade das empresas prestarem contas para seus stakeholders sobre seu desempenho em relação aos impactos socioambientais, o que resulta na emergência do tema "disclosure", ou seja, na divulgação e compartilhamento de informações que ganha cada vez mais espaço no setor corporativo (TINOCO, 2010).

No entanto, a definição do que é considerado um bom desempenho socioambiental empresarial não está clara, além das formas de aferimento desse desempenho ser constantemente desenvolvidas e aprimoradas.

Apesar disso, as formas mais comuns de comunicação do desempenho socioambiental empresarial têm sido os relatórios de sustentabilidade, o uso de indicadores ambientais e as certificações ambientais, providas geralmente por uma agência externa à organização (PERRINI; TENCATI, 2006; BANERJEE, 2002).

Um dos principais aspectos questionáveis das maneiras mais comuns de comunicação do desempenho socioambiental empresarial, ou seja, relatórios de sustentabilidade anuais, é que são informes autodeclaratórios, elaborados pela empresa ou por uma consultoria contratada para essa tarefa. Por esta razão, não é raro que muitas empresas que se autodenominam sustentáveis sejam acusadas por stakeholders externos de fazerem "green washing" ou maquiagem verde, porque suas declarações muitas vezes não são coerentes com outras ações da empresa (VOIVODIC, 2010). 
Nesse sentido pode-se dizer que os efeitos das práticas socioambientais adotadas pelas empresas se tornam reduzidas se não podem ser verificadas ou comprovadas por um agente externo à empresa. Por esta razão, a accountability empresarial tem sido uma demanda mais recente da sociedade e os meios de se obtê-la têm se tornado uma tendência para empresas que desejam manter suas posições de destaque no mercado (CONROY, 2007; PERRINI; TENCATI, 2006).

Deste modo, cada vez mais os critérios que ajustam as atividades produtivas para além da regulamentação governamental são desenvolvidos de maneira que todos os atores interessados participem, inclusive aqueles que são externos à organização (VOIVODIC; BEDUSCHI FILHO, 2011).

Surgem então novas tentativas para comparação do desempenho socioambiental empresarial, como por exemplo, o Índice de Sustentabilidade Empresarial (ISE). O ISE é uma ferramenta para análise comparativa das empresas listadas na BM\&FBovespa que considera a sustentabilidade corporativa, sob os aspectos da eficiência econômica, equilíbrio ambiental, justiça social e governança corporativa (ISE, 2014). A proposta é que o índice colabore com investidores na tomada de decisão e induza, assim, que as empresas adotem melhores práticas voltadas às questões socioambientais.

A necessidade da prestação de contas do desempenho socioambiental das empresas nos remete às ideias sobre a relação sociedade, empresas e meio ambiente, que reforça que diferentes stakeholders são capazes de influenciar o posicionamento das empresas diante da questão ambiental.

Ao assumirem publicamente sua orientação para lidar com a problemática ambiental, as empresas passam a ser observadas e ao mesmo tempo são constantemente contestadas por vários stakeholders que possuem algum tipo de interesse nas atividades destas empresas, sejam eles investidores, consumidores, competidores, governos ou organizações ambientalistas.

Deste modo, as empresas possuem responsabilidades sobre os impactos causados ao ambiente e aos stakeholders que não necessariamente estão dentro das organizações, mas que são afetados por suas atividades. Surge, portanto, a necessidade da elaboração de respostas por meio de estratégias que permitam minimizar os seus impactos socioambientais negativos, indo além do que é exigido pela legislação, e, muitas vezes, se antecipando a elas. 
Uma vez que a dinâmica empresarial pode ser influenciada para além dos custos e que isso pode ser compreendido pelas decisões e posições que vão tomando diante da problemática ambiental, há a desconstrução da ideia de que tanto o mercado como as empresas funcionam como agentes autônomos e independentes da sociedade, como defende a economia neoclássica (ABRAMOVAY, 2012).

Deste modo, pela perspectiva da Nova Sociologia Econômica (NSE) os agentes econômicos podem estar ligados entre si, na forma de grupos, instituições, e sociedade, sendo capazes de influenciar um ao outro (SMELSER; SWELDEBERG, 2005). Assim, sob este ponto de vista, "a ação econômica está incorporada em um concreto e contínuo sistema de relações sociais" (GRANOVETTER, 1985).

Obviamente a antecipação das empresas à exigência regulatória não compõe nenhuma espécie de altruísmo e também não vai contra a obtenção de lucro (ABRAMOVAY, 2007; BANERJEE, 2008). Porém, nessas atitudes proativas se estabelece a capacidade de as empresas se organizarem para a "gestão antecipada da contestação" (HOMMEL, 2004).

De acordo com Hommel e Godard (2001), como a atuação das empresas é legitimada socialmente por diferentes atores externos, a antecipação à contestação social dos impactos negativos de seus processos produtivos evita que empresas sofram ameaças que prejudiquem sua reputação, o que pode a levar a prejuízos financeiros, ampliando as incertezas e comprometendo seu futuro.

As empresas podem elaborar estratégias para se antecipar a contestação social, por exemplo, procurando reduzir as fontes objetivas de riscos potenciais, modificando as técnicas e produtos. Ou também tentando estender seu horizonte de previsão sobre os fenômenos de protesto social que, geralmente, não são facilmente previsíveis (HOMMEL; GODARD, 2001).

Abramovay et al. (2010) e Abramovay (2012) trazem a moratória da soja como exemplo do funcionamento dos mercados contemporâneos e a necessidade de interação com os diferentes stakeholders. Nesse episódio, que teve início em 2006, as empresas compradoras de soja foram responsabilizadas por ONGs internacionais que associavam o desmatamento da Amazônia para o cultivo deste produto agrícola com o sistema agroalimentar mundial. Como resposta, três grandes empresas envolvidas no caso (ADM, Bunge e Cargill) assinaram um

\footnotetext{
${ }^{6} \mathrm{Na}$ corrente anglo saxônica fala-se sobre a ideia de licença social de operação (GODARD; ADANT, 2004).
} 
compromisso com as ONGs ambientalistas se responsabilizando pelo impacto ao bioma amazônico e se comprometendo a não comprarem soja de regiões recentemente desmatadas.

O caso da moratória da $\operatorname{soja}^{7}$, apesar de sozinho não resolver os problemas do desmatamento, para Abramovay (2012) traz três pontos importantes e inéditos. O primeiro deles é que foi um acordo voluntário e privado, que ia além do que a lei preconiza, pois não permitia o desmatamento nem dos $20 \%$ admitidos por legislação. Em segundo lugar, ele destaca o papel relevante desempenhado pelas organizações não governamentais para que fosse realizado o acordo. E finalmente, a ideia de rastreamento do modo como os recursos naturais são utilizados nos sistemas produtivos.

Este exemplo retratado acima sintetiza questões formuladas sobre a relação empresas, sociedade e recursos naturais. Além disso, justifica a escolha destas duas correntes teóricas para abordar a questão desta tese: a relação das empresas e da água, pela utilização da Pegada Hídrica. Por um lado, mostra a importância de se aproximar de stakeholders externos à empresa e trabalhar para atender também seus interesses (Teoria dos Stakeholders), evitando piores efeitos da contestação social (Nova Sociologia Econômica, NSE). E por outro, mostra como a mudança de postura das empresas pode ser influenciada pelas demandas da sociedade, novamente reforçando a ideia da presença da sociedade como parte estruturadora dos mercados (NSE).

As ideias contidas na Teoria dos Stakeholders, na Nova Sociologia Econômica e na Teoria da Modernização Ecológica convergem na percepção de que as empresas podem exercer um papel importante, mas não exclusivo, no enfrentamento dos desafios em relação à água, como será desenvolvido a seguir. Além disso, as três correntes consideram também que as empresas podem sofrer influências de outros atores, o que significa que não são entidades autônomas e independentes, e que diante dessa situação respondem, pelas mais diferentes razões, às demandas que surgem externamente às organizações.

\footnotetext{
${ }^{7}$ A moratória da soja não foi renovada em 2011, o que mostra a instabilidade e tensões neste campo. Entretanto existem outras iniciativas na região de colaboração entre ONGs e empresas privadas (ABRAMOVAY, 2012).
} 


\section{Capítulo 3. Empresas e água: a construção do problema}

A água, além de um direito universal (ONU, 2010), se configura também como um recurso indispensável à manutenção dos ecossistemas e das atividades humanas. Nos últimos anos, a pressão sobre seu uso vem crescendo cada vez mais. Um dos fatores do aumento da pressão pelo uso da água é o aumento da produção e do consumo, resultado do modo como as sociedades atuais se organizam e se relacionam. Somado à crescente tendência no aumento da produção e consumo, está o crescimento da população global.

O incremento na produção de alimentos e bens de consumo causam impactos negativos no meio hídrico, tanto em relação à quantidade de água captada como na sua qualidade, principalmente por meio das atividades agrícolas e industriais, mas também pelo lançamento de efluentes de origem doméstica nos corpos d'água receptores (WWAP, 2012).

Os resultados de um mapeamento feito por Hoekstra et al. (2012) indicam que em muitas regiões do mundo, por pelo menos um período por ano o consumo de água ultrapassa a disponibilidade existente, afetando mais de dois bilhões de pessoas.

Nesse cenário de vulnerabilidade hídrica, a agricultura ganha destaque em relação aos impactos exercidos sobre a água uma vez que o setor é considerado o maior consumidor de água global (HOEKSTRA; MEKONNEN, 2012).

Através do comércio internacional de produtos agrícolas, que ocupa somente $15 \%$ da produção global, há uma relação que raramente é considerada entre a água usada na agricultura e a movimentação destes produtos no mercado internacional (SOJAMO; LARSON, 2012).

Esta relação entre água, alimento e comércio é sintetizada no conceito conhecido por água virtual, elaborado por Tony Allan em 1993, durante um seminário realizado na SOAS (School of Oriental and African Studies) da Universidade de Londres (ALLAN, 2003). O termo foi usado para descrever a ideia de que os produtos agrícolas "contém água incorporada" necessária durante seu processo de crescimento. A água virtual consiste no volume de água "contido" 8 nos produtos comercializados ao redor do mundo.

\footnotetext{
${ }^{8}$ Do inglês embedded
} 
A importância do surgimento deste conceito está na possibilidade de dar visibilidade aos impactos negativos locais sobre a água, causado pelos sistemas produtivos. Além disso, por meio do conceito de água virtual há o reconhecimento da movimentação de água ao redor do mundo, já que nos mostra que certo volume de água foi utilizado durante o processo de produção de alimentos (HOEKSTRA; HUNG, 2002; HOEKSTRA, 2009).

Sendo assim, ressalta-se o papel importante, e ainda pouco discutido, que o sistema agro alimentar exerce sobre a gestão da água em toda a cadeia de valor, ou seja, da produção e comercialização de commodities, até o processamento industrial dos alimentos (SOJAMO et al., 2012; ALLAN, 2011).

É importante ressaltar que além da indústria de alimentos, a produção agrícola é base para muitos outros setores industriais, como papel e celulose, cosmético, têxtil e biocombustível (CNI, 2013).

Estudos recentes apontam que o interesse das empresas em relação à água deve ocorrer tendo em vista as possíveis alterações na disponibilidade, não só quantitativa, mas também em qualidade aceitável, de modo que as atividades econômicas das empresas sejam mantidas sem comprometer os outros usos da água (CHAPAGAIN; TICKNER, 2012; LAMBOOY, 2011; ORR et al., 2009).

No Brasil, nos últimos anos houve um aumento da extração de água para usos consuntivos $^{9}$, sendo a agricultura irrigada responsável por $72 \%$ do consumo de água em 2010 , de acordo com a Agência Nacional de Águas (ANA, 2013). Apesar da maior parte da produção agrícola brasileira não ser irrigada, o país é considerado um dos maiores exportadores de água virtual, por meio da exportação de commodities agrícolas, principalmente soja e milho (WILLAARTS et al., 2014; HOEKSTRA; MEKONNEN, 2012; CARMO et al., 2007).

O abastecimento industrial é o quarto maior consumo de água em termos nacionais, mas corresponde ao principal uso no caso da Bacia Hidrográfica do Alto Tietê, onde está localizada a cidade de São Paulo. Apesar de o setor de alimentos e bebidas ser o setor industrial com mais pontos de captação de água registrados, as maiores vazões outorgadas são destinadas à produção de papel e celulose e metalurgia básica, correspondendo a $24 \%$ e $19 \%$ da vazão outorgada, respectivamente (ANA, 2013).

\footnotetext{
${ }^{9}$ Abastecimento público, irrigação, indústrias e dessedentação animal (ANA, 2013).
} 
Em relação à qualidade das águas, é importante ressaltar que das 27 Unidades Federativas do país, somente 17 possuem algum tipo de monitoramento da qualidade da água superficial. A má qualidade das águas está relacionada principalmente à contaminação por lançamento de esgoto doméstico ${ }^{10}$, mas também por efluentes industriais e contaminação difusa, em razão da atividade agropecuária e mineradora (ANA, 2013). De acordo com o Relatório de Conjuntura dos Recursos Hídricos no Brasil de 2013, da Agência Nacional de Águas, os piores índices de qualidade de água se encontram nas regiões com maior densidade populacional. Por outro lado, os locais onde foram observadas melhoras tiveram investimentos na coleta e tratamento de esgoto de origem doméstica.

Os impactos negativos causados pelo aumento da pressão pelo uso da água, quando associados às alterações climáticas globais podem levar ao aumento da frequência de eventos extremos, que configuram um universo de incertezas e riscos que podem afetar diversas regiões, comprometendo o uso da água para diferentes fins (IPCC, 2013).

Diante destas considerações, os principais riscos oferecidos às empresas em relação à água são identificados como riscos físicos, regulatórios e reputacionais (HEPWORTH, 2012; MORRISON et al., 2010), todos capazes de causar impactos financeiros a qualquer empresa que enfrente alguma destas situações (ORR et al., 2009).

Os riscos físicos dizem respeito à baixa disponibilidade hídrica, em quantidade e qualidade adequada, no local onde as empresas realizam suas operações, além da possibilidade de enchentes e secas. Já os riscos regulatórios estão relacionados a medidas severas tomadas pelo poder público, no caso de situação de baixa disponibilidade hídrica. Por exemplo, o enrijecimento no controle pelo uso da água, outorgas e licenças, além de poder mudar as regras em relação à água, como custos, legislação, padrões de captação e lançamento de efluentes.

E por fim, as empresas estão expostas aos riscos reputacionais quando, por não compreenderem o impacto socioambiental negativo das suas atividades, não atuam (por exemplo, impactos sobre a qualidade e quantidade de água captada e lançada, impactos sobre os serviços ecossistêmicos e comunidades), perdendo potenciais clientes/consumidores e investidores, o que prejudica sua imagem.

\footnotetext{
${ }^{10}$ Segundo os dados do IBGE (2010), em 2008 somente 55,2\% dos municípios era atendido com redes coletoras de esgotamento sanitário. Do total coletado, são tratados $68,8 \%$.
} 
No caso do setor empresarial, o que está em jogo é sua capacidade de enfrentar esse novo e incerto cenário em relação aos riscos associados à água para manter suas atividades de modo que isso não prejudique os demais usos da água, evitando assim contestações sociais.

A característica local da água e suas implicações globais se refletem também na política econômica mundial, como pôde ser observado no último Fórum Econômico Mundial, realizado em janeiro deste ano em Davos. Em uma pesquisa sobre percepção dos riscos globais, entre os dez riscos listados, a água foi apontada como a terceira maior preocupação por aqueles que a responderam (WORLD ECONOMIC FORUM, 2014).

Nesse sentido, considerando as empresas como agentes ativos, capazes de interagir e responder a outros atores atuando no mercado (ABRAMOVAY, 2012; VOIVODIC; BEDUSCHI FILHO, 2011) passa-se a refletir sobre o papel das empresas para diminuir a pressão e os impactos sobre a água (NEWBORNE; MASON, 2012; LAMBOOY, 2011).

A questão que se coloca, nesse sentido, é qual o papel e o alcance das empresas na gestão da água, já que várias ocupam posição de destaque na comercialização global de produtos (NEWBORNE; MASON, 2012; SOJAMO; LARSON, 2012).

É o que mostra o estudo realizado por Sojamo e Larson (2012). De acordo com as autoras, quatro grandes empresas do agronegócio ${ }^{11}$ atuando em diferentes países são responsáveis pela movimentação de grandes volumes de água virtual, por meio da comercialização de produtos agrícolas (SOJAMO; LARSON, 2012; SOJAMO et al., 2012).

Sojamo e Larson (2012) apontam que há uma forte correlação entre o engajamento empresarial na questão da água, visibilidade da marca e influência de stakeholders. Por meio de estudos de caso, as autoras pretendem entender a influência de grandes empresas - Nestlé, Bunge e Cargill - na gestão da água de toda a sua cadeia produtiva. Nesse sentido, elas indicam que as empresas que estão expostas a uma maior diversidade de stakeholders são mais propensas a atuarem no atendimento das demandas exigidas por eles.

Neste caso, entre as três empresas estudadas, a Bunge e principalmente a Néstlé, por serem de capital aberto, sofrem influência tanto dos seus stakeholders primários ou diretos, como sócios, acionistas, investidores, fornecedores e consumidores, mas também dos stakeholders secundários ou indiretos, como ONGs, mídia, academia, grupos ambientalistas e movimentos sociais. A Nestlé, por ser também uma marca, está exposta diretamente a

\footnotetext{
${ }^{11}$ ADM, Bunge, Cargill e Louis Dreyfus.
} 
pressões de consumidores. Por esta razão, ao mesmo tempo em que responde às demandas vindas dos seus consumidores, estimula o engajamento público. Já a Cargill, por ser uma empresa de capital fechado com poucos acionistas, está exposta a menor influência de stakeholders externos. Assim, possui uma atuação mais superficial em relação à água quando comparada com as outras empresas estudadas, além de manter um engajamento de caráter filantrópico (SOJAMO; LARSON, 2012; LARSON, 2011).

De acordo com Pegram et al. (2009), a piora da qualidade e da disponibilidade de água para a satisfação das necessidades humanas e ambientais em razão dos meios de produção, afeta a sociedade como um todo, não somente e diretamente as empresas.

O compartilhamento dos riscos atrelados à água surge, portanto, como uma questão complexa que insere a água como um recurso que depende tanto do interesse comum como de ações em colaboração para identificá-los e enfrentá-los (HEPWORTH, 2012; PEGRAM et al., 2009).

Uma das formas de engajar todos os atores envolvidos na cadeia produtiva do setor agro alimentar, apontada no estudo de Sojamo e Larson (2012), é a utilização de plataformas multi-atores onde seja possível compartilhar boas práticas, como o caso da Roundtable on Sustainable Palm Oil (RSPO) ou a Roundtable on Responsable Soy (RTRS), alternativa exemplificada também por Abramovay et al. (2010) e Abramovay (2012). Deste modo, com a participação dos atores das diferentes fases do processo produtivo, a troca de informações pode gerar aprendizado, o que traz melhores resultados.

Em relação à água, diferentes iniciativas em forma de redes têm sido criadas nos últimos anos para discutir como garantir o uso responsável da água, por meio da reunião vários setores e instituições, como será apresentado no próximo item desta Seção.

Assim, existem diferentes motivos para as empresas implementarem instrumentos de gestão da água e diminuir os volumes usados nas suas operações, além daqueles incluídos nos seus sistemas de gestão ambiental. Por exemplo, a diminuição de seus custos pelo pagamento pelo uso da água ou com tratamento da água poluída, pois algumas fases do processo produtivo são mais exigentes em relação à qualidade da água usada. Ou ainda, para evitar problemas com sua reputação, como mencionado anteriormente, e antecipar-se às futuras regulações ambientais mais restritas (HEPWORTH, 2012; LARSON et al., 2012; 
LANBOOY, 2011). Esses motivos estão relacionados com os riscos atrelados à água, explicados anteriormente (MORRISON et al., 2010).

Apesar de o argumento principal para incentivar o setor empresarial a se envolver nas questões relacionadas à água para além das exigências feitas pela legislação ambiental esteja relacionado com a redução de custos, abre-se uma possibilidade para a empresa evitar futuras contestações sociais, como argumenta Hommel e Godard (2001).

Afinal, casos como o da planta da Coca-Cola na Índia em 2006, no qual foi acusada de explorar a água subterrânea de maneira a comprometer o abastecimento público da região teve grande repercussão internacional e certamente estimula uma reflexão sobre o modo pelo qual as empresas têm atuado em relação à água nas regiões onde estão presentes. Além disso, este caso é um exemplo da necessidade de atenção sobre o conteúdo e o modo da comunicação dos seus compromissos com o uso responsável dos recursos naturais.

Um recente estudo de Karnani (2014), da Universidade de Michigan (EUA), indica que apesar da planta industrial da Coca-Cola em Kaladera, Índia, ter adotado medidas de redução do volume de água subterrânea, a empresa continua a operar para maximizar os lucros. Além disso, aponta que o grande problema da Coca-Cola foi não cumprir com os seus compromissos públicos, além da falta de transparência e accountability do seu desempenho ${ }^{12}$, atitudes apontadas como greenwashing (KARNANI, 2014).

Casos como este elucidam como é delicado determinar os limites sobre a responsabilidade do setor público e do setor privado na gestão da água. Isso porque a regulação e políticas de água são diferentes em cada país, assim como cada setor industrial causa impactos socioambientais diferentes. Assim, percebe-se que em regiões onde as leis ambientais e regulações são mais fracas, as ações de responsabilidade social corporativa também tendem a ser (KARNANI, 2014; JONES, 2010).

Isso exige ir além de simplesmente demonizar as empresas, uma vez que uma forma de legitimar a continuação de suas operações está no consumo dos produtos fabricados por elas.

\footnotetext{
12 Tem circulado nas redes sociais uma campanha intitulada "Coke Justice: Campaign to hold Coca-Cola Accountable".
} 
Deste modo, é necessário que seja feita uma profunda reflexão sobre as expectativas sociais em relação às responsabilidades que as empresas devem ter com os recursos naturais. Nesse sentido, é preciso obter informações sobre os modos de produção e sobre toda a gama de impactos associados às atividades produtivas, além de transparência na comunicação destas informações para todos os tipos de stakeholders, além de ser passível de accountability (KARNANI, 2014).

Por esta razão, alguns autores defendem que parte da resposta aos riscos e desafios atrelados à água deve surgir dentro das próprias empresas (NEWBORNE; MASON, 2012; LAMBOOY, 2011; MORRISON et al., 2010; PEGRAM et al., 2009).

Entretanto, por se tratar de um tema recente, existem poucos estudos capazes de mensurar os avanços esperados pela corresponsabilização das empresas sobre a situação hídrica nas regiões onde mantém suas atividades. De qualquer maneira, de acordo com a grande quantidade de novas possibilidades que tem surgido por meio de diferentes iniciativas que serão apresentadas a seguir, observa-se que é crescente o interesse e que existe certa mobilização por parte do setor empresarial na forma de coalizões e redes para se envolver na temática da água. 


\section{Capítulo 4. Empresas e água: a formulação de respostas}

Diante da problemática sobre as implicações no uso da água pelo setor produtivo em um cenário de crescentes riscos como apresentado anteriormente, percebe-se nos últimos anos um esforço de diferentes setores da sociedade para desenvolver ferramentas que auxiliem as empresas a ampliarem sua visão e compreenderem sua relação com a água (MORRISON et al., 2010).

Geralmente as empresas costumam reportar seu desempenho em relação ao uso da água de maneira quantitativa, de maneira limitada e fora do contexto no qual está inserida socioambientalmente. As métricas disponibilizadas nos relatórios dizem respeito ao volume de água captado e suas respectivas fontes, volume de água reutilizada e reciclada, volume de efluente lançado, sua carga poluente e metas de redução. Apesar de úteis e necessárias, tomar esses números sem informações adicionais regionais e locais é insuficiente quando se pretende promover ações a fim de melhorar o uso e a gestão da água (UNEP, 2011).

Nesse sentido, a produção e a disponibilização das informações relativas ao uso da água pelo setor empresarial beneficiarão aos diferentes stakeholders, desde os investidores como também comunidades, poder público e consumidores.

Por esta razão, há um maior envolvimento de grandes empresas de diferentes setores de uso intensivo em água na adoção de novas ferramentas para compreender a questão da água usada nos processos produtivos, além da aproximação do setor empresarial às universidades e ONGs, resultando em parcerias que pretendem desenvolver novas maneiras de compreender e gerir a água (HEPWORTH, 2012).

Nos últimos anos algumas ferramentas e guias surgem na tentativa de fornecer mais informações sobre os impactos causados à água pela sociedade, de modo que sua gestão se torne mais racional e sustentável, no sentido de não comprometer todos os usos possíveis no presente e no longo prazo.

Dentre essas iniciativas, temos, por exemplo, o CDP - Water Disclosure Initiative (CDP-Water), CEO Water Mandate, GEMI - Local Water Tool, World Business Council for Sustainable Development Global Water Tool, Ceres Aqua Gauge, WWF Water Risk Filter a norma 14046 da International Organization for Standardization (ISO), World Resources Institute Aqueduct, Global Reporting Initiative (GRI) e Avaliação da Pegada Hídrica da 
Water Footprint Network, que será tratada com mais detalhe separadamente. Estas são ferramentas e iniciativas desenvolvidas com diferentes propósitos, mas que em geral tentam contribuir para melhorar a gestão da água pelo setor empresarial.

Por certo, cada uma destas iniciativas surge com propósitos e características diferentes e não faz parte do escopo deste trabalho compará-las entre si, mas sim reuni-las e apresentar brevemente as mais conhecidas (Quadro 1).

Quadro 1. Classificação das iniciativas para gestão da água no setor empresarial. Fonte: Adaptado de Larson et al. (2012).

\begin{tabular}{|c|c|c|c|}
\hline \multicolumn{4}{|c|}{ Categorias das iniciativas para abordar a questão da água } \\
\hline $\begin{array}{c}\text { Ferramentas de } \\
\text { contabilização do uso } \\
\text { da água }\end{array}$ & $\begin{array}{l}\text { Estruturas de análise de } \\
\text { risco corporativo }\end{array}$ & $\begin{array}{c}\text { Protocolos para } \\
\text { relatórios } \\
(\text { disclosure })\end{array}$ & $\begin{array}{l}\text { Estruturas para } \\
\text { certificação e } \\
\text { Standards }\end{array}$ \\
\hline $\begin{array}{l}\text { Water Footprint } \\
\text { (WFN) } \\
\text { Norma ISO } 14046\end{array}$ & $\begin{array}{c}\text { WRI - Aqueduct } \\
\text { GEMI - Local Water } \\
\text { Tool } \\
\text { WBCSD - Global Water } \\
\text { Tool } \\
\text { UN- CEO Water } \\
\text { Mandate } \\
\text { WWF Water Risk Filter }\end{array}$ & $\begin{array}{c}\text { CDP Water } \\
\text { Global Reporting } \\
\text { Initiative (GRI) } \\
\text { CERES Aqua Gauge }\end{array}$ & $\begin{array}{c}\text { European Water } \\
\text { Stewardship - EWS } \\
\text { Alliance for Water } \\
\text { Stewardship - AWS }\end{array}$ \\
\hline
\end{tabular}

O CDP é uma organização sem fins lucrativos que tem trabalhado incentivando a transparência, engajando o setor empresarial a organizar informações sobre mudanças climáticas por meio do preenchimento de um questionário. O CDP-Water Disclosure Initiative é um programa padronizado que tem como objetivo coletar informações sobre como as empresas fazem a gestão da água, seguindo a mesma estratégia do programa de mudanças climáticas. As informações coletadas são reunidas e disponibilizá-las em uma plataforma que facilite a investigação dos riscos aos quais estão expostos, permitindo a exploração das oportunidades, contribuindo com a comunicação dessas informações para os investidores (CDP, 2014).

O questionário é dividido em governança e gestão da água, avaliação de riscos e oportunidades, contabilização e intensidade no uso da água. Os últimos tópicos fortalecem a ideia na qual a exposição financeira é identificada, indicando que o principal objetivo é 
minimar riscos para as empresas, e não para outros usuários. As informações incluídas nos questionários não são verificadas, mas é atribuída uma pontuação de acordo com a qualidade da resposta (CDP, 2014).

O relatório com os resultados CDP-Water referente ao ano de 2013 indica que mais de mil empresas ao redor do mundo responderam o questionário e houve um aumento de $59 \%$ no número de empresas que usam o CDP como guia para comunicar aos investidores seus esforços para melhorar a gestão da água em relação ao ano anterior. Assim, para $70 \%$ das empresas respondentes do questionário de 2013, á água foi identificada como um risco substantivo que causará impactos significativos em curto prazo, ou seja, nos próximos 5 anos (CDP GLOBAL WATER REPORT, 2013).

A proposta da Organização das Nações Unidas (ONU), conhecida por United Nations Global Compact é uma iniciativa política para as empresas alinharem suas operações com princípios mundiais de direitos humanos, trabalho, meio ambiente e corrupção, entre outros. Atualmente, doze mil empresas são signatárias do UN Global Compact (UNITED NATIONS GLOBAL COMPACT, 2014).

Em 2007 o UN Global Compact lançou a publicação CEO Water Mandate, uma iniciativa público-privada elaborada para colaborar com as empresas a desenvolverem, implementarem e revelarem suas políticas sobre água, fazendo da gestão da água uma prioridade. CEO Water Mandate, reconhece o papel das empresas na produção de bens e serviços, mas também os impactos causados à água. Assim, a iniciativa se alinha com os Objetivos do Desenvolvimento do Milênio (ODM), tornando a gestão da água uma prioridade (CEO WATER MANDATE, 2014a).

A iniciativa reforça ainda a importância das companhias trabalharem juntos com governos, agências internacionais, ONGs e diferentes stakeholders. A publicação cobre seis áreas: operações diretas, cadeia produtiva e gestão de bacia, ação coletiva, política pública, engajamento comunitário e transparência (LANBOOY, 2011). A partir de 2010, a participação no CEO Water Mandate se restringe a empresas signatárias do UN Global Compact.

O Global Environmental Management Initiative (GEMI) é uma organização de várias empresas que pretende desenvolver soluções em relação à sustentabilidade ambiental para o setor empresarial. Em 2007, em colaboração com o World Business Council for Sustainable 
Development (WBCSD), foi desenvolvida a ferramenta gratuita, na forma de planilha Excel disponível na Internet, conhecida como GEMI Local Water Tool (LWT), com intuito de se identificar riscos em relação à água, desenvolver planos de gestão e comunicá-los externamente (GEMI, 2012).

A Global Water Tool (GWT) é uma ferramenta gratuita disponível na Internet, também na forma de planilha Excel, desenvolvida em 2007 pelo World Business Council for Sustainable Development (WBCSD), que como o GEMI, é uma associação entre mais de 200 empresas multinacionais. A proposta da GWT é facilitar a avaliação e a comunicação tanto do uso da água nas operações e cadeia produtiva das empresas, como também aos riscos atrelados. Os indicadores usados na ferramenta estão em consonância com aqueles reportados, por exemplo, no questionário do CDP-Water e GRI (WBCSD, 2014). Pode ser usado em complementação com a GEMI-LWT, pois os resultados da análise do GWT são gerais e apenas indicativos (MORRISON et al., 2010).

A ferramenta Aqua Gauge foi desenvolvida em 2010 pelo Ceres em parceria com outras instituições, como o WBCSD, com objetivo de colaborar com empresas e investidores para avaliar, aprimorar e comunicar a gestão dos riscos atrelados à água. Fundado em 1989 por um grupo de investidores em resposta ao incidente com o Exxon Valdes, o Ceres atua acelerando e expandindo a adoção de práticas e soluções empresariais sustentáveis (CERES, 2014).

O Ceres Aqua Gauge é uma ferramenta na forma de um questionário disponível no formato de planilha Excel. Assim, ao preenchê-lo, as empresas fazem uma autoavaliação baseada nos seguintes eixos temáticos: contabilização, inclusão na gestão dos riscos relacionados à água, participação e relação com outros atores, comunicação e transparência. Para cada eixo temático, se abrem novos subtemas nos quais a atuação da empresa vai sendo classificada em "inicial", "progresso" e "liderança". A partir da compilação das informações, uma avaliação multicritério é organizada em função de um índice e um gráfico é automaticamente gerado, permitindo uma visão mais ampla da relação entre os eixos temáticos e a situação da empresa naquele momento, podendo ser possível acompanhar o desempenho ao longo do tempo. Nesse sentido o Ceres Aqua Gauge está mais orientado ao desenvolvimento de respostas às questões relacionadas à água.

Outra ferramenta disponível gratuitamente na Internet é a Water Risk Filter, desenvolvida pela ONG WWF em parceria com o banco alemão Deutsche 
Entwicklungsgesellschaft (DEG), que permite às empresas e investidores quantificar e avaliar os riscos atrelados à água no mundo. Os resultados são obtidos na mesma estrutura do questionário do CDP-Water e não exige profundo conhecimento sobre gestão da água para manuseá-la, além de os resultados serem de fácil compreensão (CEO WATER MANDATE, 2014b).

A norma 14046 da International Organization for Standardization (ISO) traz os princípios para avaliar e reportar os impactos dos produtos ou processos, com base na avaliação de ciclo de vida (ACV). Como na norma ISO de ACV, a norma 14046 prevê definição de escopo e objetivos, inventário de processos e contabilização de consumos de água associados aos processos, avaliação do impacto sobre a água em função de categorias (por exemplo, eutrofização, escassez e ecotoxicidade) e interpretação dos resultados (HERVA et al, 2011).

Na sua forma atual, a norma não define o método de contabilização e categorias de impacto à água, mas exige que as decisões sejam claramente descritas (MARZULLO; MATAI, 2012). De qualquer maneira, a norma ISO 14046 é pensada para a certificação internacional, o que muitas vezes pode dificultar uma análise mais específica, relacionada com a problemática local da região.

Há também disponível a ferramenta do World Resources Institute, conhecida como Aqueduct. O WRI - Aqueduct é um banco de dados global disponível on line que permite mapear os riscos com relação à água, colaborando com o engajamento público e privado em prol da gestão da água, facilitar informações para investidores sobre a exposição de empresas e também as respostas aos riscos enfrentados (WORLD RESOURCES INSTITUTE, 2014).

Os riscos identificados pela ferramenta WRI - Aqueduct são classificados em riscos físicos, regulatórios e reputacionais, de maneira a identificar hotspots a curto, médio e longo prazo, considerando os efeitos das mudanças climáticas a partir dos cenários desenhados pelo IPCC (CEO WATER MANDATE, 2014b).

Finalmente, o Global Reporting Initiative (GRI) tem como objetivo estabelecer um sistema para reportar a sustentabilidade econômica, social e ambiental de uma empresa. A seção sobre meio ambiente traz um conjunto de 30 indicadores de diferentes áreas, como consumo energético, água, biodiversidade, emissões, resíduos, entre outros. Com relação à água, o questionário traz perguntas sobre contabilidade do consumo de água, reuso e 
reciclagem, além de ações para mitigar danos ambientais. Apesar de não ser totalmente voltado a questões água, o GRI é uma iniciativa bastante adotada pelas empresas.

Há também iniciativas em forma de redes e plataformas multi-stakeholders que pretendem discutir temas relacionados à água, de modo a engajar o setor empresarial a usá-la de maneira responsável.

Nesse sentido podemos citar o esforço da Alliance for Water Stewardship (AWS), uma organização que possui a colaboração de outras instituições como UNEP, TNC, WWF e CDP, entre outras. Seu objetivo é incentivar o comprometimento coletivo e o compartilhamento dos riscos com relação à água, por meio de um Standard global que define uma série de princípios, critérios e indicadores de como deve se dar o uso responsável da água, no âmbito local e da bacia hidrográfica de maneira que seja ambientalmente, socialmente e economicamente benéfica (AWS, 2014; UNEP, 2011).

O Standard global foi elaborado e discutido em mesas redondas regionais (Water Roundtable) com a participação de vários grupos representantes de empresas, órgãos governamentais e sociedade civil. De modo a incentivar o engajamento pela responsabilidade no uso da água, a AWS estabelecerá uma certificação para aqueles que cumprirem os requisitos presentes no Standard.

A ideia é que cada região elabore o seu Standard, mas até o momento somente a Europa o tem pronto e já em uso ${ }^{13}$. O European Water Stewardship (EWS) é um dos programas da organização European Water Partnership, que elaborou o Standard europeu EWS antes da AWS. A equipe da AWS preferiu não aproveitar a iniciativa europeia, elaborando um novo protocolo, e por esta razão o Standard Global foi lançado em abril de $2014^{14}$ (informação verbal $^{15}$ ).

$\mathrm{Na}$ Europa, duas plantas da Coca-Cola, uma localizada na Holanda e outra na Romênia, receberam até o momento a certificação nível gold do Standard europeu da EWS em janeiro de 2013. É importante ressaltar que a certificação da EWS se dá por plantas industriais e não por empresa, uma vez que a avaliação sobre a água é baseada nas ações de cada planta e seus impactos locais.

\footnotetext{
${ }^{13}$ Cabe ressaltar que não é obrigatória a elaboração regional e, deste modo, as regiões que não quiserem ou não puderem elaborar seu Standard utilizarão a versão global.

${ }^{14}$ Lançada em abril de 2014 em Lima, Peru.

15 Apresentação da Maria Valle (EWS) no Workshop "Water Stewardship : from concept to application" realizado em 21/03/2014 na Universidad Complutense de Madrid, Madrid, Espanha.
} 
Antes do seu lançamento, o Standard Global da AWS realizou testes na aplicação do Standard em algumas empresas, como é o caso da região da América Latina e Caribe que está aplicando-o no Peru, na cadeia produtiva de aspargos da empresa Damper, e no Brasil, na bacia do rio Taquarussu pela Foz|Saneatins, empresa parte do grupo Odebrecht (AWS, 2014).

Outra iniciativa em forma de rede, mas com uma proposta mais específica que a AWS é a Water Footprint Network (WFN), criada em 2008, a partir do esforço de várias instituições, como Universidade de Twente, WWF, UNESCO-IHE, WBCSD entre outras, com objetivo de promover uma transição justa, sustentável e eficiente em relação ao uso da água, além de avançar no conceito de Pegada Hídrica e de sua aplicação. Por meio de parcerias, a WFN tem conseguido a engajar um vasto número de empresas, institutos de pesquisa e agências de governo a aplicarem a $\mathrm{PH}$ na agricultura, indústria e bacias hidrográficas (WFN, 2014; ZHANG et al., 2013).

A última versão do manual de Avaliação da Pegada Hídrica (2011), publicação que orienta a realização da avaliação da Pegada Hídrica para um produto ou país, por exemplo, está disponível gratuitamente na página na Internet da WFN em inglês, português e chinês. Além disso, como a Pegada Hídrica tem forte ligação com a academia desde o seu surgimento, a página na Internet reúne uma grande quantidade de artigos científicos e relatórios, além de um banco de dados com informações para diferentes países, sendo que muitos deles são resultados de teses de doutorado finalizadas. Nesse sentido a WFN compartilha todo o material relacionado com a aplicação da Pegada Hídrica gratuitamente ao acessar a página na Internet (WFN, 2014; ZHANG et al., 2013).

Existem outras redes que também possuem enfoque sobre a água, como o World Water Council e Global Water Partnership. Entretanto como suas funções não têm relação direta com algum método ou ferramenta voltada exclusivamente em engajar o setor empresarial a ampliar sua visão de uso da água para além de suas necessidades operacionais eles serão abordados nesta tese em outro capítulo.

Para finalizar, cabe ressaltar que todas as iniciativas apresentadas são recentes, e muitas ainda estão em desenvolvimento ou sendo testadas. Por esta razão Morrison et al. (2010) apontam alguns desafios inerentes ao uso de ferramentas de contabilização da água e identificação de riscos. 
Por exemplo, como os riscos em relação à água enfrentados pelas empresas dependem do contexto socioambiental e político de onde estão localizadas, por um lado é necessário estender o foco dos resultados em direção ao ambiente externo à organização para ter uma visão real da situação. Por outro lado, as ferramentas que permitem uma avaliação das características do ambiente externo às empresas, de modo que seja possível harmonizar estes resultados necessitam aprimoramento. Há ainda pouca ênfase no envolvimento de todas as etapas da cadeia produtiva no uso responsável da água, seja por falta de dados ou pela grande quantidade no número de fornecedores, apesar de muitas empresas concordarem que grande parte dos riscos e impactos em relação à água pode ocorrer antes da fase industrial (MORRISON et al., 2010).

Com exceção da Norma ISO 14046, que faz parte de um sistema de certificação, que prevê, deste modo, auditoria, as outras iniciativas listadas são autodeclaratórias, o que significa que as informações não são verificadas por terceiros. Essa situação pode abrir espaço para as empresas praticarem greenwashing.

Por outro lado, a utilização dessas ferramentas pode proporcionar aprendizagem para todos os envolvidos no processo, ao mostrar a relação de dependência entre a empresa e a água, independente da validade científica das ferramentas. Mesmo que algumas ainda necessitem de maior refinamento, o uso de mais de uma delas permite um olhar amplo para questões da água, que precisam ser vistas não só como mais um insumo para manutenção da atividade econômica, mas principalmente como um recurso limitado, comum a diferentes usuários e para diversos fins.

Nos exemplos das ferramentas e iniciativas citadas acima, existe a proposta de que a ciência e a tecnologia assumam um caráter de antecipação e prevenção de problemas relacionados à água, de preferência com o envolvimento de outros atores, indo mais além do que simplesmente de seu papel remediador (MOL; SPAARGAREN, 2009).

Apesar de não ser possível verificar, todavia, se essas ações colaboram com a melhoria da disponibilidade (qualitativa e quantitativa) e acesso à água, dado o pouco tempo em que é possível observar essas práticas, o surgimento das várias ferramentas e iniciativas que têm sido disponibilizadas para setor empresarial se aproximar da problemática associadas à água, pode ser entendido como o resultado da internalização do tema da água (MOL, 2010). Isso também nos remete ao caráter permeável das empresas, ao elaborar estratégias para responder 
às questões de relevância discutidas em campos externos a elas (ABRAMOVAY, 2012; SMELSER; SWELDEBERG, 2005).

Em seguida trataremos com mais detalhe sobre a ferramenta Pegada Hídrica, proposta pela Water Footprint Network, uma vez que a proposta deste trabalho se centra na discussão de sua utilização pelo setor empresarial. 


\section{Capitulo 5. Pegada Hídrica: aspectos conceituais e metodológicos}

Para melhor entender a relação entre as atividades de produção de bens e serviços para as sociedades e a crescente pressão sobre a água, tem se tornado mais comum a utilização de indicadores de consumo de água que proporcionem informações que permitam compreender a ligação entre os dois assuntos.

Uma dessas propostas é a avaliação da Pegada Hídrica (PH), método desenvolvido por Arjen Hoekstra, da Universidade de Twente, Holanda (Hoekstra, 2009) e difundido por meio da rede Water Footprint Network (WFN) que pretende contribuir com o aumento da eficiência, sustentabilidade e equidade no uso da água para a produção de bens e serviços oferecidos para as pessoas (HOEKSTRA et al., 2011).

O conceito de Pegada Hídrica (PH) é oriundo do conceito de água virtual proposto por Allan (2003), como explicado anteriormente, mas também está inserida entre os indicadores da família das "Pegadas" (Footprints), que prevê uma abordagem integrada para monitorar a pressão humana sobre o ambiente, por meio da perspectiva da produção e do consumo (CUCEK et al., 2012; GALLI et al., 2012).

Segundo Fang et al. (2014), a utilização destes indicadores da família das "pegadas" permite cobrir um amplo espectro dos temas ambientais, revelando sua complexidade. Nesse sentido, como parte desta família de indicadores, a PH tem como seus antecedentes a Pegada Ecológica e a Pegada de Carbono.

A Pegada Ecológica pretende estimar a quantidade de recursos naturais e assimilação de rejeitos de uma dada população ou economia, em termos de área de terra produtiva, com o intuito de não somente avaliar a sustentabilidade das atividades humanas, mas também aumentar a consciência das pessoas sobre a dependência e finitude dos recursos naturais e contribuir para a tomada de decisão (WACKERNAGEL; REES, 1996).

Assim, o indicador trabalha com a noção de biocapacidade e monitora a pressão antrópica à biosfera, tentando compreender as consequências causadas aos sistemas ecológicos pela extração de recursos naturais para a produção de bens de consumo. A Pegada Ecológica pode ser aplicada a diferentes escalas, desde um produto até cidades, regiões ou mesmo para o mundo todo (GALLI et al., 2012; EWING et al., 2010). 
A Pegada de Carbono mede a quantidade total de gases de efeito estufa (GEE), em toneladas de dióxido de carbono equivalente, emitidas direta e indiretamente para a produção de bens de consumo (MINX et al., 2009). Apesar do termo "Pegada de Carbono" ser mais recente, seu método já vem sendo utilizado há mais tempo, por exemplo, na avaliação do ciclo de vida dos produtos (FINKBEINER, 2009). Assim como a Pegada Ecológica, a Pegada de Carbono pode ser calculada para indivíduos, populações, países, empresas, setores entre outros (GALLI et al., 2012).

Na mesma linha que as outras duas "pegadas", a Pegada Hídrica (PH) é um conceito baseado na perspectiva do consumo, desenvolvida como um indicador multidimensional de uso direto e indireto de água, que considera a quantidade de água consumida em todas as fases de produção de um produto, seja ele agrícola ou industrial, ou também de um processo produtivo (HOEKSTRA et al., 2011; HOEKSTRA; HUNG, 2002).

Os valores de PH podem ser calculados para um indivíduo, população, regiões, países, atividades e setores industriais, produtos ou empresas desde que os valores sejam definidos temporal e espacialmente (HOEKSTRA et al. 2011).

Além disso, existem algumas diferenças entre a avaliação da $\mathrm{PH}$ e os métodos de contabilização de água convencionalmente empregados. Em primeiro lugar, a PH considera o volume de água consumido, ou seja, a água que não retorna na forma de efluente para o corpo hídrico onde foi captado. Além disso, considera a poluição resultante do processo produtivo. Em segundo lugar, a PH contabiliza também o consumo indireto de água, ampliando a compreensão de que a pressão sobre o uso da água ocorre também, e principalmente, nas fases anteriores à industrial e continuam depois do produto pronto. Em terceiro lugar a avaliação da PH estabelece uma relação entre consumo de água no local do uso e apropriação global dos recursos hídricos, a partir das relações comerciais entre diferentes países e regiões (HOEKSTRA, 2009).

Nesse sentido, a água consumida é classificada em verde, azul e cinza, em função de sua origem e impacto (Figura 1). Assim, a PH azul refere-se à água consumida ${ }^{16}$ que é captada dos corpos de água superficiais ou subterrâneos; a PH verde é definida como a quantidade de precipitação que é armazenada no solo e que é consumida pelas plantas; e a PH

\footnotetext{
${ }^{16}$ Pela perspectiva adotada por Hoekstra et al., 2011 para a PH azul, consumo se refere à perda de água por evaporação, ao não retornar à bacia de origem ou por ter sido incorporada no produto. Deste modo, o volume não-consuntivo de água não é contabilizado na $\mathrm{PH}$.
} 
cinza $^{17}$, que por se tratar de um indicador de impactos sobre a qualidade da água, é definida como a quantidade de água necessária para diluir os poluentes presentes no efluente resultante do processo produtivo que se está avaliando (HOEKSTRA et al., 2011). Portanto, a Pegada Hídrica total de um local, processo ou produto será a soma das PH azul, verde e cinza, dependendo do objetivo e escopo do projeto a ser desenvolvido.

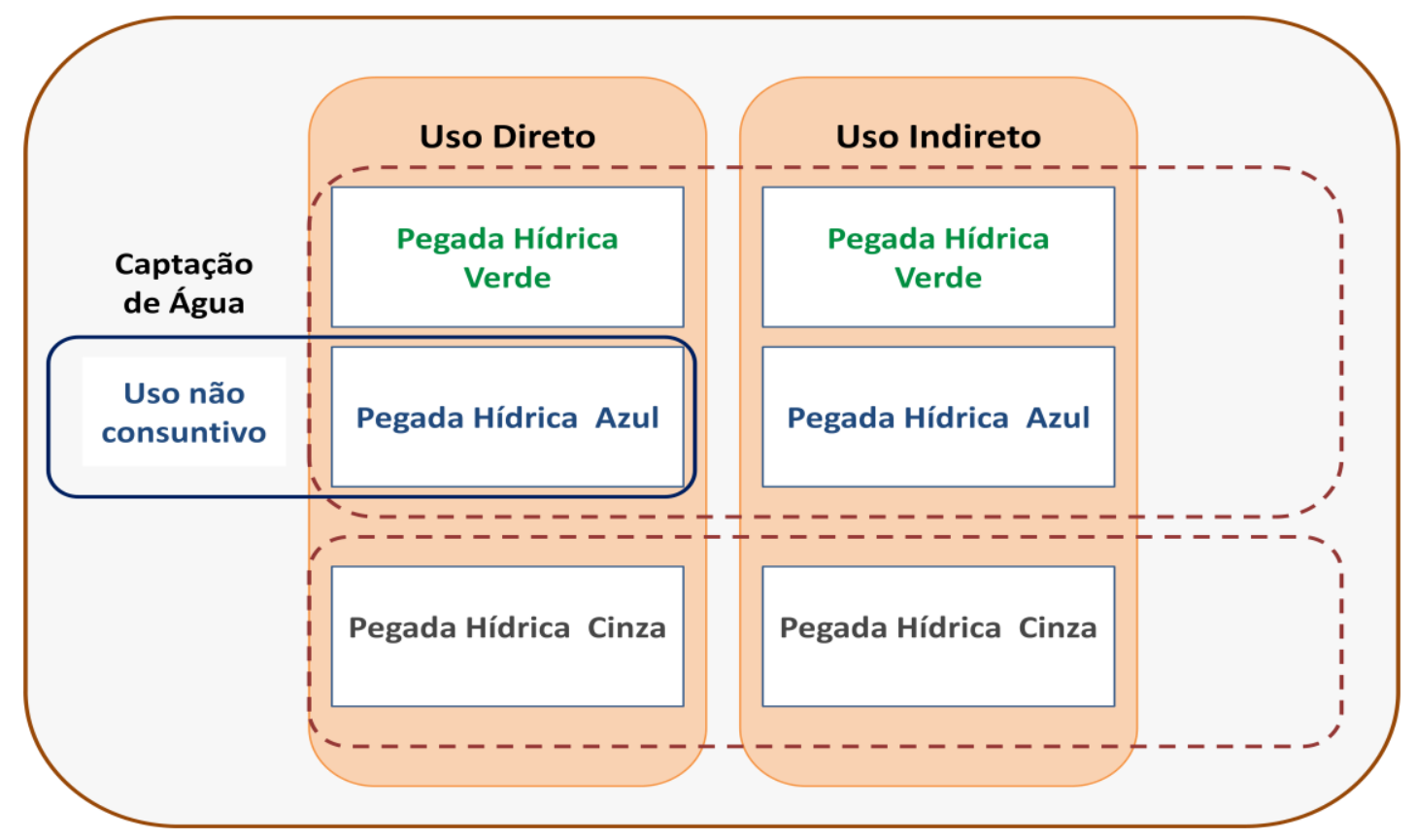

Figura 1. Esquema dos componentes de uma Pegada Hídrica. Fonte: Hoekstra et al., 2011.

Apesar de geralmente o enfoque dos trabalhos envolvendo o método da $\mathrm{PH}$ ser direcionado à contabilização do volume de água consumido durante o processo produtivo de produtos (MEKONNEN; HOEKSTRA, 2012;), a avaliação da Pegada Hídrica possui outros aspectos além do cálculo, compreendendo quatro fases (Figura 2).

Na primeira fase define-se os objetivos e o escopo do trabalho e logo, em na fase dois, realiza-se a contabilização da PH. Em seguida, na fase três, está prevista a realização da avaliação da sustentabilidade da Pegada Hídrica, que tem com objetivo trazer a discussão dos valores contabilizados na fase anterior para a escala local. A ideia, portanto, é comparar os valores de PH calculados com a capacidade hídrica da bacia hidrográfica. De acordo com Hoekstra et al. (2011), a avaliação da sustentabilidade da PH deve ser realizada pela

\footnotetext{
${ }^{17}$ Recentemente se tornou disponível na página da rede da WFN um guia complementar para o cálculo da PH cinza.
} 
perspectiva ambiental, social e econômica, para que então, na última fase, sejam elaboradas respostas e decisões sejam tomadas.

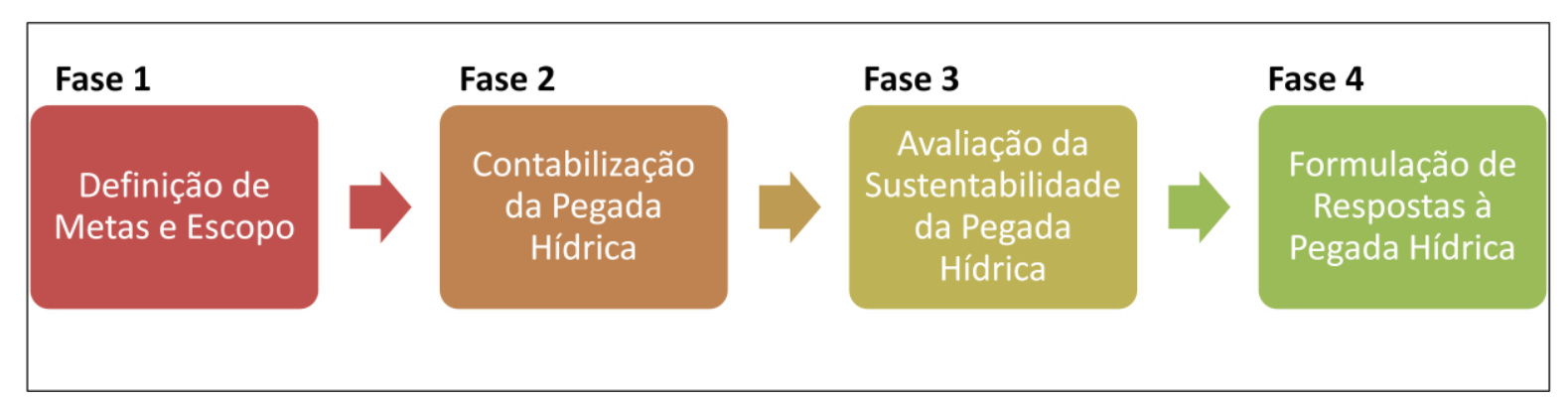

Figura 2. Fases que compõe a avaliação da Pegada Hídrica. Fonte: Adaptado de Hoekstra et al., 2011.

A avaliação da sustentabilidade da $\mathrm{PH}$ pela perspectiva ambiental significa, em termos gerais, que a $\mathrm{PH}$ total não deve comprometer a disponibilidade hídrica, qualitativa e quantitativa, de água subterrânea e água superficial para a manutenção da vida aquática na bacia hidrográfica onde o estudo está sendo realizado (HOEKSTRA et al., 2011). Assim, a PH verde e PH azul são comparadas com a situação local, a fim de verificar se o consumo contabilizado é sustentável ou não em relação à água azul e verde disponível na bacia onde o estudo foi realizado.

Já em relação à sustentabilidade social e econômica da $\mathrm{PH}$, o manual comenta muito superficialmente, sem ser capaz de orientar de forma clara e direta como fazer essa avaliação. Por exemplo, uma PH é considerada sustentável socialmente quando não compromete o acesso a água de modo equitativo para que sejam atendidas as necessidades básicas humanas daqueles que vivem na região de estudo. Como estes critérios são difíceis de serem avaliados, é mencionado no manual que a existência de conflitos pelo uso da água é um indício de que o acesso e disponibilidade hídrica podem estar sendo injustos socialmente (HOEKSTRA et al., 2011).

Por fim, em relação à sustentabilidade econômica de uma PH o manual estabelece que a água deve ser alocada e usada de maneira eficiente economicamente. Ou seja, os benefícios econômicos de uma $\mathrm{PH}$ devem exceder o custo total associado a essa $\mathrm{PH}$, incluindo as externalidades, os custos de oportunidade e custos de escassez de água. Deste modo, um critério sugerido na publicação para verificar se uma PH é insustentável economicamente é o valor cobrado pelo uso da água (HOEKSTRA et al., 2011). 
Uma maneira de trazer a dimensão econômica da água para a discussão é proposta por Garrido et al. (2010) por meio da produtividade aparente da água, indicador de performance econômica do uso da água. A produtividade aparente da água é expressa, por exemplo, em dólares por metro cúbico de água $\left(\$ / \mathrm{m}^{3}\right)$. Esse indicador é útil para dar uma ideia do valor obtido pelo uso da água em determinado processo produtivo.

Segundo Hoekstra et al. (2011), na última fase, que consiste na formulação de respostas à avaliação da $\mathrm{PH}$, é necessário identificar quem serão os responsáveis por colocar em prática as respostas elaboradas a partir dos resultados obtidos no estudo. Além de identificar os responsáveis por cada ação, é importante definir metas e estratégias para cada ação para que as respostas sejam colocadas em práticas, e que sejam realizadas mudanças na maneira de usar e consumir a água. É desejado que as respostas sejam desenvolvidas depois da avaliação da sustentabilidade da PH (fase 3). Porém, dependendo do objetivo do caso, também é possível que medidas sejam tomadas depois da contabilização da PH (fase 2).

As respostas elaboradas depois do estudo de PH deve ter como finalidade sua redução, que deve ocorrer inclusive em locais onde não há baixa disponibilidade hídrica, superficial ou subterrânea. As formas de reduzir uma PH podem ir desde a otimização de um processo, pelo aumento da eficiência no uso da água, até medidas de compensação que devem ocorrer na mesma bacia hidrográfica onde a água é consumida. No entanto, esta questão sobre medidas compensatórias em relação à PH, ao contrário da Pegada de Carbono, não estão bem definidas mesmo no manual (HOEKSTRA et al., 2011). Na prática, quando consideramos um processo produtivo, é possível verificar a redução do valor da $\mathrm{PH}$ quando se aumenta a produtividade da água, o que implica produzir mais com menores volumes de água. Poderíamos dizer então que temos uma PH relativa. Porém, a perspectiva relativa da $\mathrm{PH}$ não é o suficiente, quando pensamos no cenário crescente de consumo de água para os sistemas produtivos para atender às sociedades contemporâneas, marcadas pelo consumismo. Deste modo, é preciso considerar de alguma maneira também o que podemos chamar de $\mathrm{PH}$ absoluta, que compreenda o volume de água consumido em dado período de tempo, por exemplo. É esse valor absoluto que pode orientar ações para que não haja depleção da água de modo que comprometa a capacidade de o sistema estar em constante equilíbrio.

De acordo com Aldaya (2014), até o momento, a maioria dos estudos de PH publicados, na forma de artigos científicos ou relatórios, alcançaram a segunda fase, ou seja, o cálculo da PH. Isso pode ocorrer por motivos relacionados à recente consolidação do método 
para um público mais amplo, já que até poucos anos a discussão sobre Pegada Hídrica era fundamentalmente tratada em âmbito acadêmico. Isso se deu até 2010, quando houve um treinamento na Holanda, coordenado pela Water Footprint Network (WFN), sobre a aplicação da contabilização da água a partir do enfoque dado pela Pegada Hídrica. O treinamento teve a participação de pessoas de diferentes setores, como universidades, ONGs, empresas e consultorias. Deste modo, segundo Aldaya (2014) os trabalhos têm chegado até a segunda fase porque seu método foi estabelecido e ficou conhecido mais recentemente pelo setor público e empresarial (informação verbal ${ }^{18}$ ).

A dificuldade em ir além da fase de contabilização e avaliar a sustentabilidade da Pegada Hídrica pela perspectiva ambiental (HOEKSTRA et al., 2011) pode estar relacionada ainda com o momento de contextualizar o significado do resultado da $\mathrm{PH}$ na bacia ou região hidrográfica em questão. Para isso são necessárias informações e dados que, muitas vezes, não estão disponíveis ou não existem, dependendo da região, o que inviabiliza a avaliação da sustentabilidade da PH.

É importante ressaltar que a relativização do resultado final é importante e necessária, pois somente o valor da $\mathrm{PH}$ não dá a real dimensão da pressão exercida sobre a água pela apropriação humana que está sendo analisada. Uma PH do mesmo "tamanho" pode significar problemas em uma bacia que possui conflitos pelo uso da água ou enfrenta baixa disponibilidade em dada época do ano, ao mesmo tempo em que em uma região com alta disponibilidade hídrica e pouca demanda, sua pressão será menor.

A contribuição da aplicação da Pegada Hídrica pode justamente ser no caminho de tornar visível algo que até então era pouco considerado: a pressão e os riscos associados à água (e a outros recursos naturais, obviamente) pela perspectiva do comércio e consumo, como poderá ser visto a seguir.

\subsection{Pegada Hídrica - Principais aplicações em âmbito internacional}

É possível observar nos últimos anos uma variedade de estudos, com enfoques distintos que empregam o método da Pegada Hídrica para avaliação do consumo da água.

\footnotetext{
${ }^{18}$ Aldaya, M. 2014. Seminario sobre la aplicación de la Huella Hídrica en la política pública y empresarial: Pros y contras. 25/02/2014. Fundación Botín, Madri, Espanha.
} 
Neste subcapítulo, longe de esgotar a discussão sobre a aplicação da PH, serão apresentados estudos que aplicaram o método com diferentes enfoques e argumentações, como sua utilização em políticas públicas e governança da água ou com relação ao comércio de água virtual, principalmente de produtos agropecuários, em escala regional, nacional e global. Primeiramente serão apresentadas as experiências internacionais e em seguida, a utilização da $\mathrm{PH}$ em estudos realizados no Brasil.

Cabe ressaltar que a discussão relacionada à $\mathrm{PH}$ e empresas será tratada em um capítulo separado, apresentado na Seção III.

Como mencionado anteriormente, é possível aplicar a avaliação da Pegada Hídrica desde indivíduos, passando por empresas e produtos, até regiões hidrográficas, países e também para o mundo todo (HOEKSTRA et al., 2011).

Para Hoekstra (2011), idealizador do conceito de PH, a água é considerada um recurso global necessário à manutenção das atividades humanas (econômicas, sociais, culturais) e à medida que a pressão sobre este recurso natural aumenta, surge a necessidade de responder a essa demanda.

De acordo com Hoekstra et al., (2011), a PH pode ser aplicada com a finalidade de identificação de hotspots de uma bacia hidrográfica ou represa, permitindo a identificação do período ou local nos quais a captação e consumo de água se torna insustentável, por ser considerada abusiva ou economicamente ineficiente.

Alguns autores sugerem que o problema em relação à escassez hídrica está muito relacionado à gestão da água realizada nestes locais (ALDAYA et al., 2010; ALDAYA; LLAMAS, 2008).

Nesse sentido, concluem que a utilização da contabilização da PH e fluxos de água virtual permite produzir informações que contribuem para a melhoria da tomada de decisão que combinem uso eficiente da água e melhoria da disponibilidade hídrica local (ALDAYA; LLAMAS, 2008; ZHANG; ANADON, 2014).

Como um exemplo de uso da PH no auxílio da gestão da água temos o caso do Ministério do Meio Ambiente da Espanha, que regulamentou recentemente que a PH deve ser usada como ferramenta para a implementação dos Planos de Gestão de Bacia Hidrográfica, previstos na Diretiva da Água da União Europeia. Deste modo, Aldaya et al., (2010) indicam 
que realizar uma análise da $\mathrm{PH}$ de bacias hidrográficas pode promover de maneira transparente a identificação de alternativas para melhorar e eficiência do uso da água no nível de bacia hidrográfica. Entretanto, os autores reconhecem que apesar de se avaliar a dimensão da alocação dos recursos hídricos e econômicos da região, outras dimensões devem ser consideradas com ferramentas complementares, como riscos, desenvolvimento rural e impactos sociais relacionados ao uso da água (ALDAYA et al., 2010).

Em um estudo recente, Dumont et al. (2013), analisam a PH da Bacia Hidrográfica do Guadalquivir (localizada na Espanha). O artigo apresenta os resultados da contabilização da PH azul para água superficial e subterrânea separando os valores pelo tipo de fonte de água, o que não é muito comum nos trabalhos de Pegada Hídrica, e de acordo com os autores, a análise dos número de modo desagregados faz diferença para a gestão da água.

Segundo os autores, o aumento do uso de água subterrânea para irrigação na região, principalmente no cultivo de oliveiras, representa quase a totalidade da $\mathrm{PH}$ azul da bacia. Nesse sentido, o artigo aponta que os processos de governança e cooperação melhorariam a situação de disponibilidade hídrica na bacia desde que garantissem a realocação da água para todos os usos (DUMONT et al., 2013).

Além da aplicação como uma ferramenta de auxílio à gestão da água, a utilização da PH tem permitido elucidar a relação de interdependência hídrica entre alguns países, reforçando a interconexão existente entre o sistema natural e o social (CHAPAGAIN; TICKNER, 2012).

Nesse sentido, os estudos de contabilização de PH nacionais, de maneira geral, têm como objetivo compreender qual é a relação de dependência de um país a outros, pela perspectiva do uso e pressão sobre a água, por meio das relações comerciais internacionais, como importação de bens (MEKKONEN; HOEKSTRA, 2012; HOEKSTRA; HUNG, 2002).

Ou ainda, entender qual é a vulnerabilidade de algumas nações aos riscos de escassez hídrica global, já que, por exemplo, 62\% da $\mathrm{PH}$ da agricultura do Reino Unido está relacionada à água virtual contida nos produtos importados de outras regiões do mundo (CHAPAGAIN; ORR, 2008).

Dessa forma, ao analisar a relação importação/exportação de produtos agrícolas, por meio do comércio de água virtual, é possível identificar os principais países exportadores e importadores de água (HOEKSTRA; HUNG, 2005). 
Além disso, permite também discutir a relação pressão versus preservação de recursos hídricos entre países exportadores e importadores de produtos agrícolas (CHAPAGAIN et al., 2006a; MEKONNEN; HOEKSTRA, 2010).

Podemos citar, por exemplo, o estudo de Chapagain et al. (2006b), que avaliaram a PH dos principais países consumidores de algodão, observando os impactos transfronteiriços sobre o consumo de água (água azul) e poluição (água cinza) nos locais onde o algodão é produzido. Assim, por meio da aplicação da contabilização de água da cadeia produtiva dos produtos é possível identificar em qual fase e qual local está sofrendo maior pressão por demanda de água e pode-se, assim, elaborar maneiras de melhorar sua gestão.

Nesta mesma linha, há estudos que pretendem compreender os fluxos de água virtual entre diferentes regiões dentro de um mesmo país, como o estudo realizado por Zeng et al. (2012). Os autores contabilizaram a PH de uma bacia hidrográfica localizada no noroeste da China, região árida e semiárida, e observaram que PH azul é maior do que a disponibilidade hídrica da bacia em oito meses num ano, demonstrando que PH não é sustentável.

Em outro trabalho, é verificado que a região norte da China é responsável pela produção de alimentos de origem agrícolas que são exportados para a região sul, abundante em água. A exportação de alimentos para o sul da China representa 10\% do consumo de água do norte, região que enfrenta escassez hídrica severa. Para compensar a pressão pelo uso do recurso, há um projeto de transposição de água do sul em direção ao norte. Entretanto, os resultados obtidos no estudo de Ma et al., (2006) indicam que os volumes de água virtual exportados para o sul são maiores do que os volumes de água presentes no projeto de transposição.

Mekonnen et al. (2012) realizaram um estudo de PH das flores cultivadas no lago Naivasha, Quênia, cuja produção está sendo acusada por piorar a qualidade da água da bacia, interferindo em outros usos. O cultivo de flores, exportadas principalmente para Holanda, Reino Unido e Alemanha, tem causado impactos pela abstração de água azul do lago e também pela contaminação causada pelo uso de fertilizantes nitrogenados.

Considerando a importância socioeconômica da atividade para a região e os custos da produção, os autores propõem que um fundo seja criado para que os produtores, principalmente aqueles não têm meios para atender a legislação ambiental, possam investir em tecnologias que permitam melhorar a eficiência do uso da água e diminuir sua PH (azul e 
cinza majoritariamente). Aproveitando o interesse dos consumidores por práticas produtivas menos degradantes, é proposto no artigo que seja acrescido o valor de 0,01 euros no valor final, pago pelos consumidores, para fomentar este fundo, gerando aproximadamente 16,9 milhões de euros por ano, muito mais do que é arrecadado pelo valor da água pago pelos usuários (MEKONNEN et al., 2012).

Apesar de ser uma solução possível para contribuir com a melhora da eficiência no uso e gestão local da água, mas pouco explorada até o momento em outros estudos de PH e fluxo de água virtual, os autores apontam que o maior desafio está associado à criação de mecanismos institucionais que permitam que o fundo de recursos financeiros pagos pelos consumidores possa realmente funcionar (MEKONNEN et al., 2012).

É possível observar que, de maneira geral, o que está por trás da discussão sobre estudos de contabilização de PH e fluxos de água virtual circulando entre os países está o argumento de que o comércio de alimentos é um mecanismo que pode contribuir para economizar água em regiões que enfrentam problemas de escassez hídrica, contribuindo para a segurança hídrica e alimentar mundial (FADER et al., 2011; BULSINK et al., 2010; ALLAN, 1998).

Essa questão ganha mais relevância quando se trata de países que usam a água verde (água de chuva) para a produção agrícola, uma vez que esta fonte de água possui custo de oportunidade menor do que o de água azul (água superficial e/ou subterrânea usada para irrigação) (ALDAYA et al., 2010).

Entretanto, como a produção de alimentos está relacionada com outras questões de âmbito social, político e econômico, como por exemplo, mercados, tecnologias, acordos comerciais e incentivos econômicos, quando se olha essa questão mais de perto, percebe-se que muitas vezes as regiões exportadoras de água virtual possuem severos déficits hídricos (VERMA et al., 2009; MA et al., 2006), o que demonstra que a situação da disponibilidade hídrica nas regiões produtoras não é considerada na hora de negociar no comércio internacional (VELÁSQUEZ, 2007).

Considerando que alguns países são considerados grandes exportadores de água virtual, principalmente de água verde, como por exemplo, Brasil, Índia, EUA, Argentina, Austrália e Canadá (WILLAARTS et al., 2014; HOEKSTRA; MEKONNEN, 2012; CARMO et al., 2007), estudos que analisem mais detalhadamente a PH regional do setor agropecuário, 
bem como seus fluxos de água virtual, podem contribuir para avaliar de maneira sistêmica os impactos e custos socioambientais causados pelo consumo de água para a produção e exportação de alimentos, permitindo melhor planejamento e tomada de decisão.

Mas por outro lado, a pergunta que surge é se os benefícios para o país ou região dentro do país são maiores do que o passivo socioambiental que é coletivizado por todos ou se apenas poucos se beneficiam à custa do compartilhamento dos efeitos negativos. É interessante notar que também por meio da água a questão do poder (econômico) se torna presente e a assimetria entre as nações continua sendo reproduzida.

Nesse sentido, estes trabalhos permitem discutir como o padrão e hábitos de consumo mantidos por alguns países podem impactar negativamente a disponibilidade hídrica em outras regiões, comprometendo o acesso à água em muitos locais que, além de tudo, possuem fragilidades do ponto de vista de recursos hídricos e econômico (SEBASTIAN; WARNER, 2013; HOEKSTRA; CHAPAGAIN, 2007).

Assim, uma recente discussão tem emergido sobre o processo, no qual poderosos atores são capazes de controlar ou realocar para benefício próprio, a água usada por comunidades locais, causando conflitos e injustiça ambiental (PERREAULT et al., 2012).

Esse processo, também conhecido como "water grabbing” (BEEKMAN; VELDWISCH, 2012), está associado diretamente ao land grabbing, que é a apropriação de terra principalmente para a produção agrícola, com ocorrência em países da África, América Latina, sul e sudeste da Ásia e também no Oriente Médio (WARNER et al., 2013; BEEKMAN; VELDWISCH, 2012; HERTZOG et al., 2012).

Segundo Mehta et al., (2012), esse processo de alto impacto local tem ocorrido em razão das características complexas em relação à água, como suas variações ao longo do tempo e do espaço, adicionada à natureza silenciosa deste tipo de apropriação, como relações de poder assimétricas entre os usuários de água, confusão entre a legalidade e formalidade do direito, falta de clareza dos limites e jurisdições administrativas e processos de negociação fragmentados.

Apesar da grande contribuição do surgimento dos conceitos e estudos sobre água virtual e Pegada Hídrica para o entendimento da pressão causada pela sociedade à disponibilidade hídrica, é preciso considerar que outros aspectos em relação à segurança alimentar e hídrica influenciam as decisões, como aspectos geopolíticos, acirrando conflitos 
pelo uso da água e causando injustiça ambiental nas comunidades afetadas em função destes complexos processos como land e water grabbing (SEBASTIAN; WARNER, 2013; PERREAULT et al., 2012; LOPÉZ-GUNN; LLAMAS, 2008).

\subsection{Pegada Hídrica - A experiência nacional}

No Brasil, as primeiras iniciativas da utilização da PH como indicador de uso da água surgiram em 2010 e 2011. Os primeiros setores produtivos a aplicarem a PH foi o setor pecuário (suinocultura e bovinocultura) e o setor industrial (cosmético, celulose, bebidas), que será tratado em um capítulo à parte.

Em março de 2011 ocorreu em São Paulo o primeiro Curso Regional sobre Pegada Hídrica no Brasil, organizado pela The Nature Conservancy (TNC) em parceria com o WWF, USP de São Carlos e Water Footprint Network (WFN). O curso contou com a presença do Prof $^{\circ}$ Arjen Hoekstra, idealizador do conceito Pegada Hídrica e teve cerca de 50 participantes, de diferentes setores e instituições (TNC, 2011).

Em junho desse mesmo ano, houve, também em São Paulo, o Seminário Internacional "Pegada Hídrica e sua aplicabilidade no setor público e privado: experiências nacionais e internacionais" $" 19$. O evento teve a presença do co-fundador da Water Footprint Network, Ashok Chapagain, reunindo pesquisadores de diversas instituições de referência na temática, além de técnicos da indústria brasileira, para fomentar a discussão sobre a Pegada Hídrica e sua aplicação como ferramenta na gestão dos recursos hídricos.

A partir deste período começa então a surgir trabalhos no Brasil que utilizam a PH. Porém, até o momento, ao contrário do que vimos em relação a outros países, quase não há estudos de $\mathrm{PH}$ com foco em análise nacional. Primeiramente pelo método da $\mathrm{PH}$ ser relativamente recente, mas também, e principalmente, dadas as dimensões continentais do Brasil, presença de diferentes biomas e condições climáticas, socioambientais, culturais e econômicas do país, que podem gerar resultados pouco significativos, além da dificuldade de obtenção de dados.

\footnotetext{
${ }^{19}$ O seminário foi organizado pelo grupo de pesquisa sobre Governança Socioambiental da Universidade de São Paulo (GovAmb/USP).
} 
Considerando a realidade brasileira, é preciso refletir se o esforço empregado com o levantamento de dados para o cálculo de PH nacionais é válido e mais que isso, qual o significado dos resultados e como podem contribuir para melhorar a gestão e governança da água.

Como exemplo, há o estudo realizado por Palhares (2011), no qual calculou a PH da suinocultura da região centro-sul do Brasil. Os resultados obtidos indicam que se faz necessária uma visão amplificada da gestão da água pelo setor, de modo que alcance toda a cadeia produtiva. Além disso, o autor argumenta que com uma visão mais ampla das relações existentes entre suinocultura, água e ambiente é possível propor políticas integradoras, que além de melhorar a eficiência do uso da água, também subsidiem discussões entre tomadores de decisão e população para melhoria da governança da água.

Mendonça et al. (2013) realizou um estudo da PH da bovinocultura de corte do Brasil, concluindo que é possível diminuir a PH da cadeia produtiva da carne quando o manejo das áreas de pastagem é realizado.

Já é possível observar a aplicação da $\mathrm{PH}$ com outras finalidades, demonstrando o caráter flexível que pode ser dado à ferramenta, dependendo do objetivo de estudo que se quer alcançar. Por exemplo, Tadeu e Sinisgalli (2013) e Tadeu (2014) utilizaram a PH para quantificar o impacto da silvicultura de eucalipto sobre a disponibilidade de água na bacia hidrográfica do rio Paraíba do Sul, em comparação com a vegetação nativa.

Os resultados apontam que pode haver competição pelo uso da água pelas coberturas vegetais estudadas nos meses mais secos, em relação aos outros usos da bacia. Além disso, os autores indicam que a plantação de eucalipto altera a provisão de serviços ecossistêmicos que podem afetar negativamente a qualidade da água na bacia hidrográfica (TADEU; SINISGALLI, 2013).

O conceito desenvolvido por Hoekstra et al. (2011) tem caráter antropocêntrico, já que considera na contabilização da PH somente a água apropriada pela humanidade, por diferentes atividades. Nesse sentido, os estudos realizados por Tadeu e Sinisgalli (2013) e Tadeu (2014) são um exemplo dos desdobramentos e adaptações que surgem naturalmente com o tempo, ampliando as discussões sobre $\mathrm{PH}$, como foi feito ao introduzirem a questão dos serviços ecossistêmicos. 
Tendo em vista a existência de poucos trabalhos que discutem a poluição industrial pela perspectiva da $\mathrm{PH}$, em um trabalho recente sobre a produção de celulose, Empinotti et al. (2013) discutem como o valor de PH cinza pode ser influenciado e alterado, dependendo da escolha do poluente presente no efluente e também pela variação da legislação de qualidade da água do local do estudo. De acordo com os resultados, as autoras consideram que a comparação entre PH cinza do mesmo setor industrial sujeitas à diferentes limites legais de qualidade da água pode não colaborar com a diminuição da contaminação das águas. Por esta razão, os resultados de um estudo de $\mathrm{PH}$ devem sempre ser considerados a partir do seu contexto sociopolítico, econômico e ambiental.

Além dos estudos de contabilização de água, que resultam em um valor de PH, Jacobi (2012) propõe uma reflexão sobre o potencial que o método tem para facilitar a comunicação e a aprendizagem nos processos de discussão e tomada de decisão referente à água, em âmbito público e privado. Nesse sentido, espera-se maior compreensão dos stakeholders envolvidos nos processos de negociação e decisão, em prol a uma melhor gestão da água.

Cabe ressaltar que existem outros estudos de mestrado e doutorado que utilizam o método Pegada Hídrica em andamento, mas que no cenário nacional os estudos sobre Pegada Hídrica são ainda incipientes.

\subsection{Principais reflexões críticas acerca da Pegada Hídrica}

A avaliação da Pegada Hídrica tem recebido grande visibilidade nos últimos anos, o que tem resultado em diferentes aplicações do seu método. Apesar disso, como todos os outros métodos disponíveis, ela apresenta algumas limitações.

Iniciaremos pelas considerações sobre as questões conceituais apontadas por alguns autores.

O conceito do componente cinza da Pegada Hídrica tem sofrido algumas críticas por não se tratar de um volume real. Como forma de atender a uma demanda daqueles que já manejam os cálculos da $\mathrm{PH}$, recentemente o componente cinza, que foi adicionado mais recentemente à avaliação da $\mathrm{PH}$, ganhou um guia que complementa sua aplicação (FRANCKE et al., 2013). 
Para Cucek et al. (2012) a PH cinza trata-se de uma estimativa subjetiva, já que é um volume teórico, ou seja, o volume de água necessário para diluir determinado contaminante até o limite aceitável pela legislação ambiental do corpo hídrico onde o efluente é lançado.

Dada a sensibilidade do resultado de $\mathrm{PH}$ cinza como efeito da escolha do poluente e variação do limite legal (EMPINOTTI et al., 2013), Deurer et al. (2011) recomendam que a informação do poluente e também dos valores de concentração do poluente usados no cálculo da PH cinza (concentração natural e concentração máxima permitida legalmente) venham sempre junto do seu resultado, facilitando a compreensão do estudo.

Ao mesmo tempo, se por um lado a flexibilidade do método permite maior possibilidade de aplicação como vimos há pouco por meio de alguns trabalhos realizados, por outro isso não permite comparações, a não ser que todas as variáveis usadas no cálculo sejam as mesmas.

Nesse sentido, é possível observar também que algumas discussões estão associadas com a aplicação da avaliação da Pegada Hídrica, suas respostas e interpretação dos seus resultados, como por exemplo, a comparação dos resultados de PH.

Assim, uma questão importante que deve ser evitada depois de se realizar a contabilização da PH é comparação entre os valores obtidos para o mesmo setor econômico ou produto, pois muitas variáveis usadas no cálculo podem não ser as mesmas e sua inclusão é capaz de influenciar o valor final da PH (EMPINOTTI et al., 2013). No final, pode-se acabar comparando coisas diferentes, que não trarão benefício algum.

Esta é uma das razões pelas quais a introdução do valor da $\mathrm{PH}$ em rótulos e etiquetas se torna uma questão delicada. Isso porque a menor PH não revela quais são as condições hídricas no local da produção e tampouco a pressão exercida à bacia hidrográfica, já que a informação vem sem seu contexto social, ambiental e econômico.

Nesse sentido, a presença do valor final da PH, expresso por exemplo, em litros por unidade produto, em etiquetas ou embalagens é insuficiente para a tomada de decisão por um consumidor, porque não é capaz de demonstrar quais são as implicações sociais, ambientais e econômicas originárias de tal processo produtivo (WICHELNS, 2011). Isso se torna muito mais complexo quando consideramos que, muitas vezes, a cadeia produtiva completa de alguns setores envolve diferentes locais, desde regiões até países, como é o caso da indústria de alimentos ou têxtil (GERBENS-LEENES et al., 2013; CHAPAGAIN et al., 2006b). 
Portanto, com a simples comparação entre os valores de PH dos mesmos setores ou produtos assume-se que as condições ambientais, tecnológicas, climáticas, sociais, culturais e hídricas são as mesmas (POSTLE et al., 2011).

A partir dos estudos de $\mathrm{PH}$ internacionais, relacionados principalmente à produção e comercialização de alimentos, é possível observar a ênfase dada no caráter global da água, que ganha visibilidade a partir do conceito de água virtual (HOEKSTRA, 2011).

Dada atenção destes estudos à relação entre segurança alimentar e hídrica no mundo, muitas vezes se deixa de lado que a água, apesar de "circular" no mundo na sua forma virtual, é um recurso que deve ser gerido no seu âmbito local. Entretanto, apesar de existir possibilidades de se desenvolver e implementar mecanismos que considerem a dimensão global da água, como protocolos internacionais sobre o custo real da água, plataformas globais de discussão e troca de experiências ou arranjos em diferentes níveis para melhorar a governança da água (HOEKSTRA, 2011), é importante ressaltar que a gestão da água deve ser realizada a partir da bacia hidrográfica.

Há outro grupo de observações feitas em relação às respostas fornecidas pela PH. Isso é mais comum de se observar quando os trabalhos reúnem vários indicadores ou métodos para compará-los mediante algum critério estabelecido pelo autor da pesquisa.

Zonderland-Thomassen e Ledgard (2012) consideram que apresentar o resultado de um estudo na forma de uma PH total faz com que se perca a relevância do tema, pois as cores das pegadas hídricas (azul, verde e cinza) estão associadas a diferentes questões ambientais que podem ser exploradas e melhor discutidas se apresentadas de forma fracionada.

Nestes casos, é possível identificar apontamentos direcionados a significância e insuficiência da contabilização da PH na identificação e avaliação de impactos à água causados pelas atividades avaliadas (CUCEK et al., 2012; WICHELNS, 2011) ou ainda que a avaliação da PH não considera o triple botton line da sustentabilidade - ambiental, social e econômica (MORI; CHRISTODOULOU, 2012).

Isto não deixa de ser verdade, porém Hoekstra et al. (2011) deixam claro que a PH é um indicador que mede a apropriação da água utilizada pela espécie humana, capaz de identificar a pressão causada à água pelas atividades de produção e consumo. Existem outras ferramentas que são capazes de medir o impacto de tais processos produtivos, como a Análise do Ciclo de Vida (ACV). 
Entretanto, é possível uma aproximação da verificação dos impactos de uma PH por meio da avaliação da sua sustentabilidade, compreendida na fase 3 do método proposto por Hoekstra et al. (2011). Para alcançar este nível mais profundo de análise, é necessário ter dados das bacias hidrográficas disponíveis, além de ser preciso maior objetividade e clareza por parte da WFN nas orientações sobre como avaliar a sustentabilidade de uma PH pelo ponto de vista social e econômico.

Até o momento, a grande maioria dos estudos de PH se baseia na contabilização do consumo de água. No entanto, como o aprofundamento é processual, assim como é constante o desenvolvimento do método, é provável que com o passar do tempo e a partir de experiências que vão sendo realizadas, seja cada vez mais comum a avaliação completa da PH (informação verbal ${ }^{20}$ ).

Apesar de todas as possibilidades de refinamento do método de avaliação da $\mathrm{PH}$, Wichelns (2011) acredita que nem a água virtual nem a PH são critérios suficientes para determinar estratégias comerciais e respostas políticas. Segundo ele, em relações comerciais é equivocado aplicar a lógica da vantagem comparativa para justificar que países com baixa disponibilidade hídrica importem produtos intensivos no uso da água de locais com abundância hídrica como tem sido feito porque os custos de oportunidade, que ademais são variáveis, não são incluídos nestes estudos.

A utilização dos resultados da avaliação da $\mathrm{PH}$ em políticas públicas, também é questionada, pois muitas vezes pela falta de dados ou qualidade dos dados, os resultados da contabilização podem se tornar frágeis o que pode prejudicar o planejamento e a tomada de decisão. Além disso, os formuladores de políticas devem considerar aspectos sociais, econômicos e políticas em relação à água, e outras questões como, por exemplo, o uso e ocupação do solo e a PH não atende estas necessidades (PERRY, 2014; WICHELNS, 2011).

Ao mesmo tempo, a PH é capaz de conscientizar as pessoas que a água é necessária para a produção de qualquer bem ou serviço utilizado pela sociedade (JACOBI, 2012). Por ser de fácil comunicação, nesse sentido, ela pode ser utilizada como apoio às políticas de educação, na formação de educadores em projetos realizados em escolas e parques, por exemplo.

\footnotetext{
${ }^{20}$ Aldaya, M. 2014. Seminario sobre la aplicación de la Huella Hídrica en la política pública y empresarial: Pros y contras. 25/02/2014. Fundación Botín, Madri, Espanha.
} 
Por outro lado, nenhuma ferramenta ou indicador tem a capacidade de sozinho, responder a todas as questões e necessidades e, portanto, a PH não difere de outros métodos. Assim, ela não deve ser utilizada na esperança de resolver todos os problemas relacionados à água. Ao contrário, é importante ter claro quais são as limitações que sua utilização apresenta para extrair as respostas adequadas ao objetivo do trabalho.

Por esta razão, Fang et al. (2014) recomendam a combinação no uso de diferentes indicadores e ferramentas para assim melhor retratar a complexidade inerentes às questões ambientais. 


\section{Seção II - Aspectos Metodológicos da Pesquisa}

Em função da recente emergência do tema estudado neste trabalho, esta pesquisa se caracteriza como exploratória. Por esta razão, e com intenção de atender ao objetivo proposto nesta tese, optou-se por utilizar três estratégias metodológicas diferentes: levantamento documental, revisão sistemática de literatura e estudos de caso, cujos resultados são apresentados e discutidos em três capítulos separadamente.

A escolha por desenvolver esta pesquisa utilizando três diferentes instrumentos deu-se porque entendemos que uma abordagem é complementar a outra, e que sendo assim, seria possível obter respostas mais consistentes, que permitiriam uma compreensão mais profunda do fenômeno estudado nesta tese. Nesse sentido, pretendeu-se compreender os motivos que explicam a utilização da PH pelas empresas, inicialmente por uma perspectiva geral, representada pelo levantamento documental, no sentido de uma abordagem intermediária, obtida por meio da revisão bibliográfica sistemática, para aprofundar a análise nos estudos de caso, que oferece uma perspectiva mais detalhada do objeto de estudo (Figura 3).

A descrição de cada procedimento metodológico será apresentada a seguir.

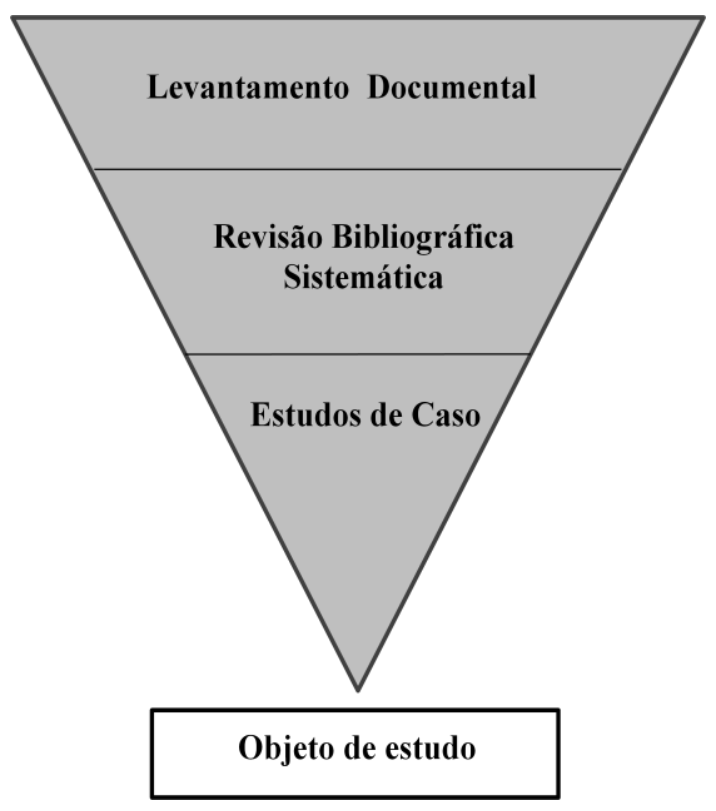

Figura 3. - Esquema que representa os procedimentos metodológicos utilizados em relação à aproximação do objeto de estudo. Elaborado pela autora. 


\section{Levantamento Documental}

Como primeira aproximação para compreender como o setor empresarial insere-se nas discussões relacionadas à água, o procedimento metodológico utilizado foi um levantamento documental. Esta etapa consistiu na busca de dados e informações sobre os principais eventos que abordaram questões sobre a água em diferentes fontes como periódicos científicos, livros, mas principalmente na Internet.

A partir de textos sobre água que mencionavam eventos relevantes sobre o tema, em um primeiro momento foi realizada uma busca dos principais eventos e organizações que tratavam da temática da água. Estas primeiras fontes forneceram informações sobre outras fontes e como na montagem de um quebra-cabeça (PIMENTEL, 2001), as "peças" foram reunidas e organizadas.

A partir da sistematização das informações levantadas, foi elaborada uma linha do tempo, que compreende um resgate histórico que permite identificar quando ocorre a inserção do setor empresarial nas discussões sobre as questões relacionadas à água e em qual contexto deu-se esta inserção.

\section{Revisão Bibliográfica Sistemática}

Uma revisão bibliográfica sistemática (RBS) pode ser realizada por diferentes razões, como por exemplo, servir de base para pesquisas posteriores, aprender sobre a amplitude da pesquisa sobre determinado tópico ou ainda, responder às questões práticas através do entendimento do que as pesquisas existentes dizem sobre algum assunto (OKOLI; SHABRAM, 2010).

No caso deste trabalho, devido à recente utilização da Pegada Hídrica pelo setor empresarial, a revisão bibliográfica sistemática se mostrou útil e adequada para reunir informações sobre as pesquisas realizadas até então e responder à pergunta de pesquisa da tese. Para tanto, a revisão bibliográfica sistemática foi conduzida em três fases (Figura 4) e teve como base a estrutura proposta por Conforto et al. (2011), conforme descrito a seguir. 


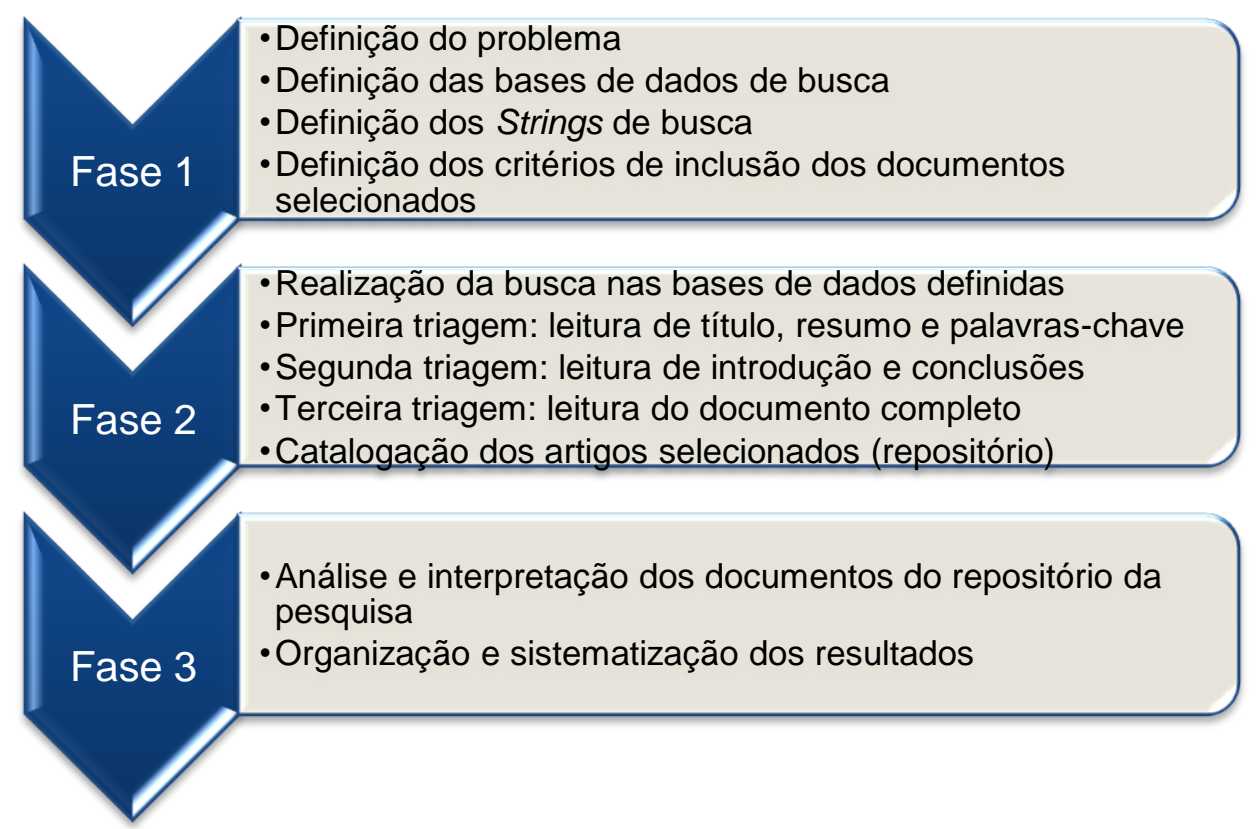

Figura 4. Fases da revisão bibliográfica sistematizada adotada nesta pesquisa. Elaborada pela autora.

A Fase 1 consistiu em quatro etapas: a) definição do problema a ser respondido; b) definição das bases de dados de busca; c) definição dos strings de busca; e d) definição dos critérios de inclusão dos artigos para análise.

Assim, foi definido que os documentos analisados na RBS (etapa a) responderiam quais são os motivos que têm levado as empresas a utilizarem a Pegada Hídrica para abordar a temática da água.

Para a realização da RBS, foram definidas que as buscas ocorreriam em duas bases de dados (etapa b): Web of Science e página na Internet da Water Footprint Network. A base de dados Web of Science foi escolhida por ser considerada uma referência (CONFORTO et al., 2011) e a página da Water Footprint Network porque disponibiliza relatórios de empresas que utilizaram a Pegada Hídrica, além de artigos científicos.

Os strings de busca (etapa c) utilizados na base de dados Web of Science foi o termo “water footprint”. Já na página da Footprint Network não foi necessário utilizar o termo de busca, pois todos os documentos disponíveis na página tratam-se do tema Pegada Hídrica. Deste modo, todos os documentos disponíveis no site foram considerados. 
Finalmente, os critérios de inclusão dos documentos catalogados e analisados nesta pesquisa (fase d) foram definidos em: i) documentos [artigos científicos e relatórios] que utilizaram o método da Water Footprint Network ii) documentos que aplicaram a Pegada Hídrica no âmbito empresarial, independente do escopo do estudo (cadeia produtiva completa ou parcial); iii) estudos que tenham relação com uma empresa real.

Durante a Fase 2 da RBS, a busca nas bases de dados foi realizada e os documentos obtidos foram triados, passando por três filtros, de acordo com os critérios de inclusão acima mencionados.

A triagem na página da Water Footprint Network foi realizada nos dias 5 e 6 de maio de 2014. Já o levantamento na base de dados Web of Science ocorreu nos dias 19 e 20 de maio de 2014.

$\mathrm{Na}$ primeira triagem foram lidos os títulos, resumo e palavras-chaves de cada documento. Aqueles documentos selecionados passaram pela segunda triagem, na qual foram lidas a introdução e conclusões. Finalmente, aqueles que foram selecionados passaram pela terceira triagem e lidos integralmente.

É importante ressaltar que foram catalogados e considerados na análise desta pesquisa exclusivamente os documentos que se atendiam os três critérios anteriormente apresentados.

Em seguida, na Fase 3, os documentos selecionados foram analisados e interpretados e incluídos no repositório de artigos da pesquisa. Nestes documentos foram identificados os motivos que têm levado as empresas a utilizarem a Pegada Hídrica para abordar a temática da água. Durante a análise dos documentos foi observado que os motivos que justificavam a utilização da PH estavam presentes no início do texto, geralmente na introdução, e voltavam a ser mencionados depois da apresentação dos resultados, nas considerações finais ou conclusões. Por esta razão, os motivos pelos quais as empresas utilizaram a PH foram extraídos dos documentos e sistematizados em "antes da realização do estudo de PH" e “depois da realização dos estudos de $\mathbf{P H}$ ".

Os motivos que justificaram a escolha da utilização da $\mathrm{PH}$ identificados nos documentos foram reunidos e, por semelhança no teor das respostas, foram classificados em quatro categorias, nomeadas como: vantagens do método, riscos, comunicação com stakeholders e tomada de decisão. Na Figura 5 podem ser observados alguns exemplos dos motivos que justificam a utilização da $\mathrm{PH}$ identificados nos documentos analisados. No 
Apêndice 1 estão organizadas as diferentes informações sobre os documentos analisados, inclusive as respostas antes de passarem pela categorização.
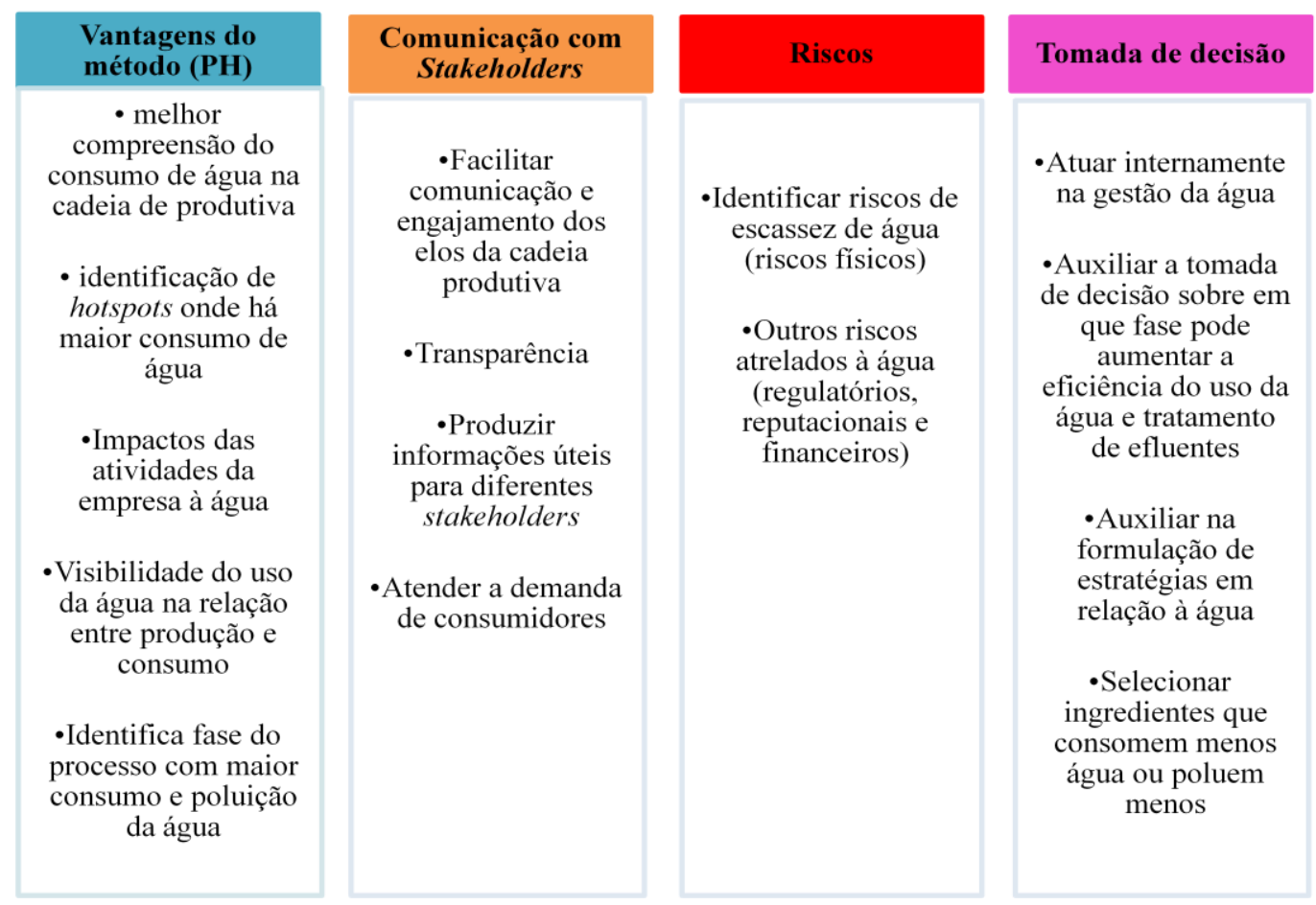

Figura 5. Exemplos de respostas extraídas dos documentos analisados por categoria criada. Elaborado pela autora.

É interessante observar que as categorias de motivos que têm levado as empresas a utilizarem a $\mathrm{PH}$ estão relacionadas com os referenciais teóricos desta tese. Porém uma categorização é uma forma de organização dos motivos e não há correspondência plena entre as categorias e os referenciais teóricos. Um referencial teórico explica parte de várias categorias e as categorias são explicadas por mais de um referencial teórico. Isso reforça a necessidade de empregar vários referenciais teóricos que se complementam para compreender a complexidade dos motivos que têm levado as empresas a se aproximarem da questão da água através da PH (Figura 6).

Nesse sentido, podemos sugerir que a Teoria da Modernização Ecológica, na sua vertente "fraca" ${ }^{21}$ está presente nas categorias "vantagens do método" e "tomada de decisão" quando relacionadas com questões internas à empresa. Por outro lado, quando o diagnóstico

\footnotetext{
${ }^{21}$ De acordo com Christoff (1996).
} 
realizado pela "vantagem do método" permite "comunicação com stakeholders" e cooperação para além da unidade industrial, elas estão associadas abordagem forte da TME.

O conteúdo mobilizado na Teoria dos Stakeholders neste trabalho está associado à categoria "comunicação com stakeholders", ao reconhecer que existem outros atores além dos acionistas interessados na temática da água. Por fim, as ideias da Nova Sociologia Econômica se aproximam tanto da categoria "comunicação com stakeholders" como de "riscos", tendo em vista que reconhece a antecipação por parte das empresas às demandas originárias vindas da sociedade e governos, por exemplo.

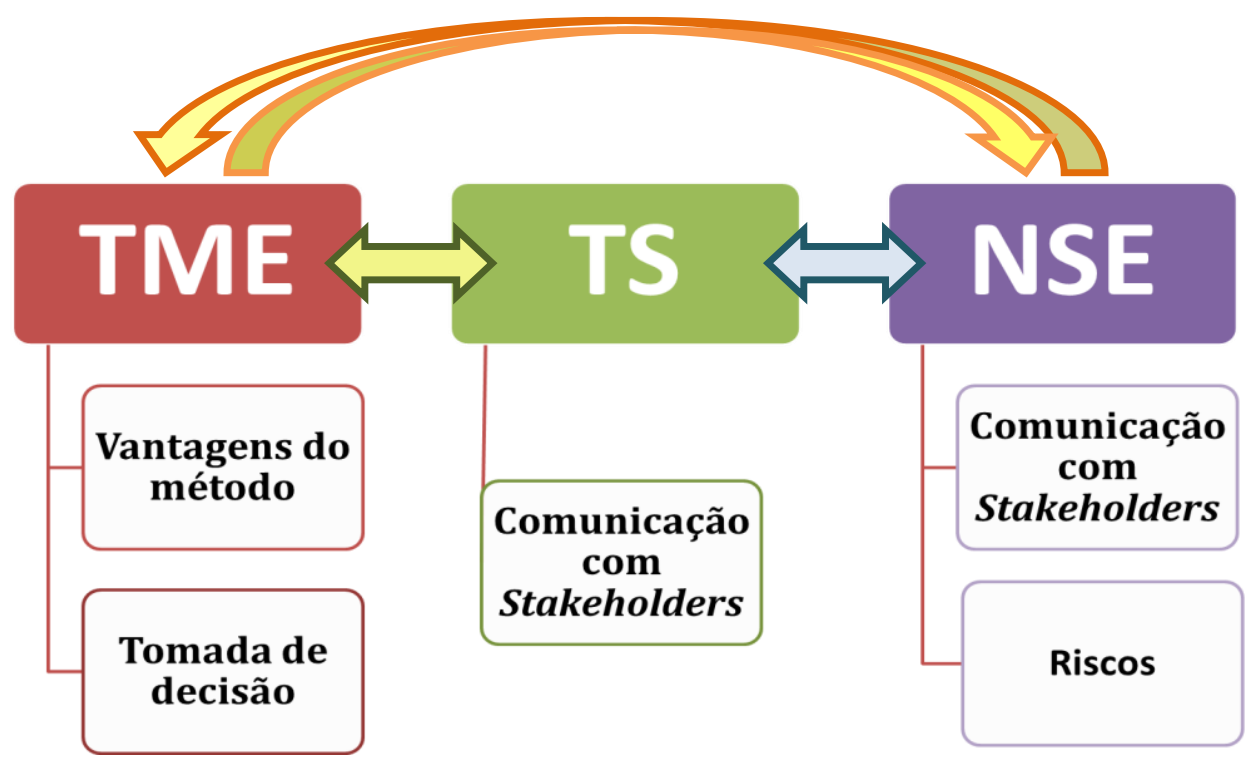

Figura 6. - Relação entre os referenciais teóricos e categorias que justificam a utilização da PH pelo setor empresarial. Elaborado pela autora.

\section{Estudos de caso}

O terceiro procedimento metodológico adotado nesta pesquisa foi o estudo de caso (MINAYO, 2010; YIN, 2005). A escolha desta abordagem ocorreu tendo em vista a necessidade de aprofundar o entendimento sobre os motivos que têm lavado as empresas a utilizarem a PH e também confirmar as informações adquiridas na revisão bibliográfica sistemática. 
Os estudos de caso foram realizados com duas grandes empresas brasileiras que utilizaram a Pegada Hídrica em seus processos produtivos: Natura, do setor de cosmético e higiene pessoal, e Fibria, empresa do setor de papel e celulose.

A escolha da Fibria e Natura como casos a serem estudados nesta pesquisa justifica-se porque ambas são pioneiras no Brasil em utilizar a avaliação da $\mathrm{PH}$ de seus produtos e/ou unidades operacionais e também porque trata-se de duas grandes empresas brasileiras que são consideradas referência nos seus respectivos setores. Ainda, cabe ressaltar que no Brasil são poucas as empresas que possuem resultados de experiências com este indicador, uma vez que sua utilização pelo setor empresarial é recente.

É importante elucidar que uma terceira empresa brasileira, representante do setor de bebidas, foi contatada para compor o conjunto de estudos de caso desta pesquisa. Entretanto, por razões de políticas internas que não permitem divulgar externamente seus projetos corporativos, não aceitou participar desta pesquisa.

Assim, para a coleta de dados foi realizada uma entrevista semiestruturada com o responsável por conduzir ou coordenar os estudos de $\mathrm{PH}$ em cada uma das empresas.

O objetivo das entrevistas foi compreender as motivações que levaram Natura e Fibria a aplicar a avaliação da PH e também entender quais foram os desdobramentos dos estudos realizados.

A entrevista com a Gerente Científica de Tecnologias Sustentáveis da Natura ocorreu no dia 26 de novembro de 2013 e teve aproximadamente uma hora e meia de duração. Já a entrevista com o Gerente Geral de Meio Ambiente Industrial da Fibria ocorreu no dia 05 de dezembro de 2013 e durou aproximadamente uma hora. Ainda, ambas as entrevistas foram gravadas e transcritas. Cabe ressaltar que os dois entrevistados assinaram o Termo de Consentimento Livre e Esclarecido, que os informava do que se tratava a pesquisa que eles estavam participando.

É importante esclarecer que o objetivo de apresentar os dois estudos de caso não é comparar as duas empresas, até porque elas fazem parte de setores distintos. A intenção é justamente observar as diferenças e semelhanças no que envolve as questões sobre água e, no caso desta pesquisa, sob a perspectiva dos estudos de $\mathrm{PH}$ por elas desenvolvidos. O objetivo, portanto, foi buscar indícios que permitissem responder à pergunta de pesquisa e confirmar ou refutar as hipóteses iniciais. 
Nesse sentido, as questões realizadas durante as entrevistas foram divididas em quatro tópicos, elaboradas a partir das reflexões nascidas das leituras que compõem as considerações teóricas desta tese. Sendo assim, os tópicos compreendidos nas entrevistas foram: a) Gênese da Pegada Hídrica na empresa - a emergência da água na agenda corporativa; b) O estudo de Pegada Hídrica na Natura e na Fibria; c) As relações entre os diferentes stakeholders e Pegada Hídrica; d) O futuro da Pegada Hídrica.

A partir da transcrição das duas entrevistas, os resultados foram organizados em um texto dividido nos mesmos quatro temas acima apontados. A discussão foi elaborada em um subcapítulo posterior à apresentação das informações obtidas nas entrevistas. Assim, a parte que compreende os estudos de caso (Capítulo 8) foi escrita baseada nas informações concedidas pelos entrevistados.

De maneira a complementar a visão sobre a aplicação da avaliação da Pegada Hídrica por parte das empresas, foi realizada uma entrevista com o coordenador de Água Doce do Programa de Conservação da Mata Atlântica e das Savanas Centrais da organização não governamental The Nature Conservancy $(\mathrm{TNC})^{22}$, organização que tem atuado junto ao setor empresarial para abordar questões relacionadas à água.

Cabe ressaltar que a TNC está envolvida com a temática da Pegada Hídrica desde antes do início da formação da rede Water Footprint Network, atuando como parceira e na coordenação da tradução do manual de avaliação da Pegada Hídrica para o português (Hoekstra et al., 2011). Atualmente, a TNC tem trabalhado em parceria com a empresa multinacional Kimberly-Clark tanto na contabilização como também na compensação da PH, por meio do plantio de mata ciliar na bacia do Alto Tietê, localização da planta onde foi realizado o estudo (KIMBERLY-CLARK, 2014).

\footnotetext{
${ }^{22}$ Como nos outros dois casos, o entrevistado da TNC também assinou o Termo de Consentimento Livre e Esclarecido.
} 


\section{Seção III - Resultados}

Esta terceira parte da tese é composta por três capítulos nos quais são apresentados os resultados obtidos por meio de três procedimentos metodológicos diferentes. O primeiro capítulo apresenta a linha do tempo, resultado da realização de um levantamento documental a fim de contribuir para a compreensão sobre quando e em qual contexto as empresas começam a participar das discussões internacionais sobre água.

No capítulo seguinte são apresentados os resultados originados da revisão bibliográfica sistemática. O segundo capítulo pretende identificar quais são os motivos que levaram as empresas dos documentos analisados a utilizarem a Pegada Hídrica.

O terceiro capítulo é resultado dos estudos de caso realizados com duas grandes empresas que realizaram estudos de PH. Neste capítulo é possível compreender como a água é percebida pelas empresas, além de verificar as razões que as levaram a utilizar a PH e qual é sua opinião sobre o indicador.

É importante esclarecer que em cada capítulo optou-se por primeiro apresentar os resultados encontrados a partir da aplicação de cada procedimento metodológico para em seguida, em um subcapítulo subsequente aos resultados, realizar a discussão dos dados e informações com o referencial teórico apresentado na Seção I desta tese. 


\section{Capítulo 6. A água na agenda global- Uma Linha do Tempo}

Inicialmente, a expansão de uma ética ecológica, em direção aos valores e preocupação com a questão ambiental acontece de forma não linear e tem início nos países desenvolvidos e posteriormente nos outros países (LEIS; D’AMATO, 2005).

Nesse sentido, as questões relacionadas à água não surgem como tema prioritário na história do ambientalismo mundial. Para ter uma melhor compreensão da entrada do tema água na agenda mundial e entender o contexto no qual a Pegada Hídrica surge, foi realizado um resgate histórico organizado e apresentado em ordem cronológica (Figura 7). Tem-se como finalidade, identificar os principais acontecimentos que configurem e expliquem o momento no qual a Pegada Hídrica surge.

A primeira aparição da preocupação com a conservação ambiental ocorreu durante a década de 1950, no campo científico, a partir da noção de ecossistema e da Teoria Geral dos Sistemas (LEIS; D’AMATO, 2005). Dois anos antes, em 1948, a União Internacional para a Conservação da Natureza (IUCN, sigla em inglês) é fundada e em 1949 acontece a Conferência Científica das Nações Unidas para a Conservação e Utilização dos Recursos Naturais (JOHNSON, 2012).

A década de 1960 é marcada principalmente pelo envolvimento dos atores sociais, a partir do surgimento de diversas organizações não governamentais (ONGs), como é o caso do World Wide Fund for Nature (WWF), primeira ONG de atuação mundial, fundada em 1961 (LEIS; D’AMATO, 2005).

O ambientalismo não governamental consolida-se e institucionaliza-se na década de 1970, tanto nos Estados Unidos como na Europa. Ao mesmo tempo, é durante este período que se registra o começo da preocupação ambiental de governos e partidos políticos, a partir do surgimento das agências ambientais, como a Environmental Protection Agency (EPA) nos EUA (HOFFMAN, 1997) e no Estado de São Paulo, a atual Companhia de Saneamento Ambiental (CETESB).

Neste período foram publicados “A Lei da Entropia e o Processo Econômico" em 1971, na qual Georgescu Roegen, precursor da Economia Ecológica, faz uma crítica radical à economia neoclássica a partir da perspectiva da termodinâmica, e ainda o relatório solicitado pelo Clube de Roma, "Limites do Crescimento" em 1972. 


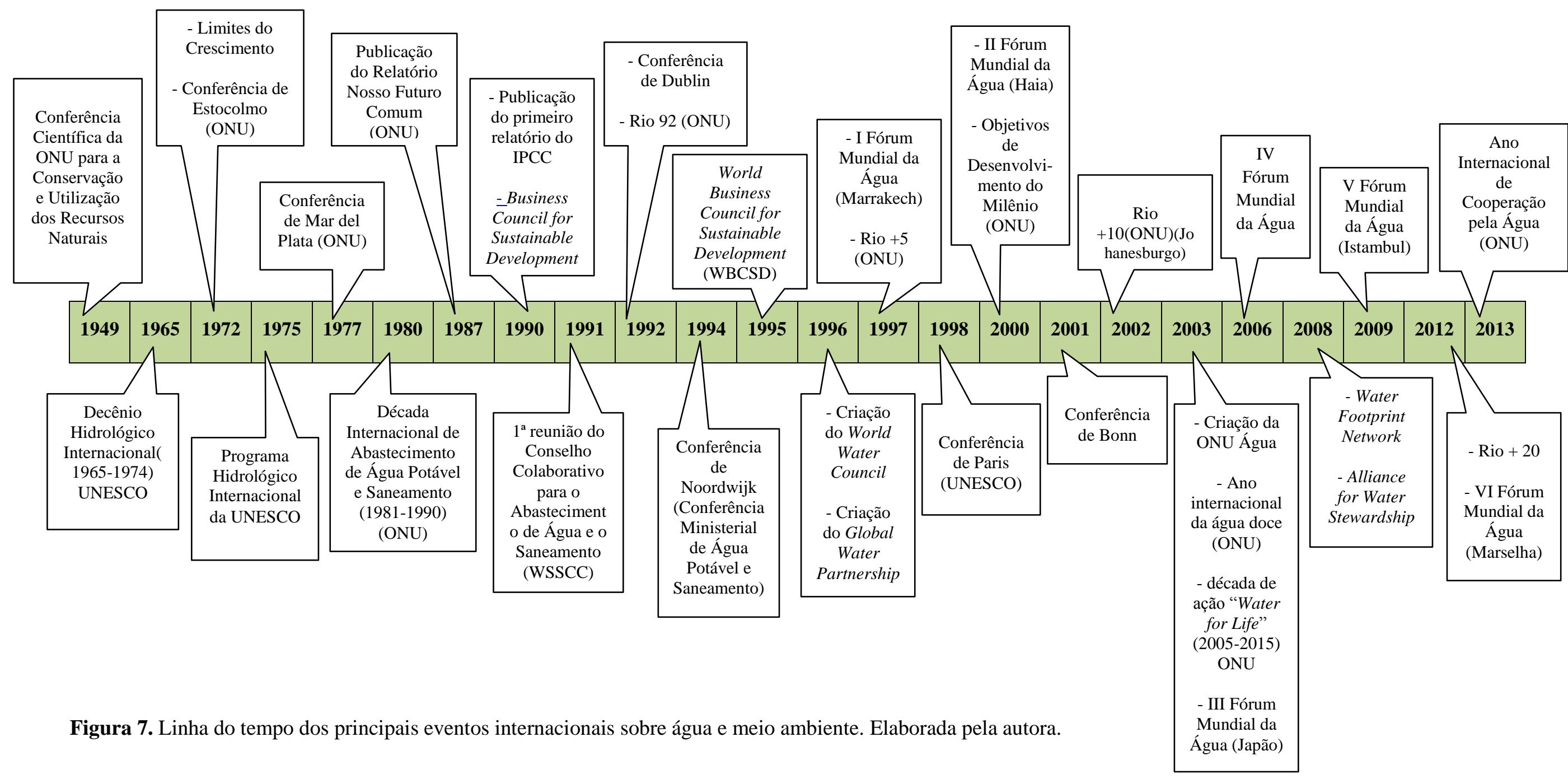


Neste mesmo ano, em 1972, ocorre a Conferência das Nações Unidas para o Meio Ambiente Humano, conhecida como Conferência de Estocolmo, por ter sido ali realizada, e tem como resultado um Manifesto com 19 princípios, representando um manifesto ambiental (ONU, 2013). A Conferência de Estocolmo foi fundamental para institucionalizar o debate ambiental na agenda global e aproveitando os esforços reunidos, a Assembleia Geral da ONU estabelece em dezembro de 1972 o Programa das Nações Unidas para o Meio Ambiente, o PNUMA (JOHNSON, 2012;).

Em 1965, a UNESCO determina o Decênio Hidrológico Internacional (1965-1974), com objetivo de inventariar a situação hídrica no mundo por meio da implantação de redes meteorológicas e hidrológicas de informações básicas, sistematizá-las e divulgá-las. Isso porque em 1965, durante a primeira reunião internacional sobre água, realizada em Washington, EUA, com objetivo de discutir cooperação técnica para enfrentar os problemas de abastecimento de água, percebeu-se que faltavam informações para a elaboração das estratégias para enfrentar o desafio de acesso a água (ASSOCIAÇÃO BRASILEIRA DE ÁGUAS SUBTERRÂNEAS, 2014).

O Programa Hidrológico Internacional da UNESCO, criado em 1975, permanece até os dias de hoje como um programa intergovernamental de cooperação científica sobre pesquisa, gestão, educação relativas à água. Sua atuação ocorre no âmbito de ampliação do conhecimento por meio de elaboração de novos métodos e abordagens que permitam melhorar a gestão da água no nível local e global, servindo como plataforma que catalisa processos de cooperação em torno dos temas mundiais sobre questões da água (UNESCO, 2014).

Como resultado do decênio hidrológico internacional (1965-1974) proposto pela UNESCO, em 1977 a água ganha destaque com a Conferência de Mar del Plata, realizada na Argentina, primeira conferência das Nações Unidas sobre água (VARGAS, 2000), inaugurando um subsistema da ordem ambiental internacional específico para a água. Apesar de um número reduzido de participantes, este encontro é considerado um marco referencial, pois foi a primeira reunião internacional para tratar de temas relacionados à água e teve como principal foco o estabelecimento de meios que evitassem uma possível crise. Esperava-se assim, reforçar acordos de cooperação internacional para a solução de problemas vinculados ao tema (RIBEIRO, 2008). 
A Conferência de Mar del Plata teve dois produtos como resultados: o "Plano de Ação" e a "Década Internacional de Abastecimento de Água Potável e Saneamento", compreendida de 1981 a 1990. O "Plano de Ação" é considerado o primeiro documento oficial inteiramente voltado para a questão da água e continha resoluções e recomendações (SILVA, 2008). Foi acordado que cada país membro deveria elaborar políticas públicas de acesso a água e saneamento básico e já se considerava situação de escassez hídrica em algumas regiões específicas. Os principais pontos abordados foram sobre a eficiência e planejamento do uso da água e o controle da poluição, educação e pesquisa, além do estímulo à cooperação internacional e regional para enfrentar as questões relacionadas a problemas de quantidade e qualidade de água (RIBEIRO, 2008).

A Década Internacional de Abastecimento de Água Potável e Saneamento (19811990) foi implementada pela Assembléia Geral da ONU em 1980, por meio da resolução 35/18. A proposta do decênio era ampliar o acesso à água potável e os serviços de saneamento básico àqueles que não tinham acesso, através principalmente de infraestrutura.

Além do marco representado pela "Década Internacional de Abastecimento de Água Potável e Saneamento", que defendia acesso equitativo à água de boa qualidade e serviços de saneamento, há também durante a década de 1980 a publicação do relatório "Nosso Futuro Comum", em 1987, resultado da formação da Comissão Mundial sobre Meio Ambiente e Desenvolvimento (World Comission on Environment and Development) pela ONU em 1983 (ONU, 1997a).

É a partir da publicação do relatório "Nosso Futuro Comum" coordenado por Gro Harlem Brundtland, que se percebe a incorporação dos atores vinculados aos diferentes setores econômicos às questões ambientais. Com a idéia de desenvolvimento sustentável e um mercado verde, se observa na década de 1990, o setor corporativo interessado em desenvolver práticas que melhorem seu desempenho ambiental (LEIS; D’AMATO, 2005).

Dez anos depois, em 1990 em Nova Delhi, Índia, os resultados da Década Internacional de Água e Saneamento foram analisados e considerados abaixo da expectativa. Porém, Ribeiro (2008) aponta que mesmo com resultados pouco expressivos, a Conferência de Mar del Plata proporcionou o aumento de pesquisas sobre a situação dos recursos hídricos em diversos países com a criação do Programa Hidrológico Internacional pela UNESCO, criado em 1975. 
No mesmo ano de 1990 é publicado o primeiro relatório do Painel Intergovernamental sobre Mudanças Climáticas (IPCC, sigla em inglês). Os seguintes relatórios foram divulgados em 1995, 2001, 2007, quando se afirma com 90\% de certeza que a causa do aquecimento global é antrópica, e o último em 2013 (IPCC, 2014). Os pesquisadores apontam nos estudos que as mudanças climáticas afetarão a disponibilidade hídrica por conta do aumento da frequência de eventos extremos, como fortes chuvas e secas prolongadas, agravando a situação em relação à água em muitas regiões (NOBRE et al., 2010).

Em 1991 acontece a primeira reunião do Conselho Colaborativo para o Abastecimento de Água e o Saneamento (WSSCC) em Oslo, Noruega, congregando representantes de diversas organizações multilaterais, centros de pesquisa e ONGs, cuja sede foi estabelecida em Genebra, junto à Organização Mundial da Saúde, OMS. Atualmente o WSSCC é vinculado ao escritório de serviços para projetos da ONU e serve como um corpo internacional que busca alcançar cooperação entre os setores de fornecimento de água, saneamento e higiene, especialmente para a região da África e Ásia (WSSCC, 2014).

No ano de 1992, houve dois eventos importantes na escala mundial. O primeiro foi a Conferência Internacional sobre Água e Meio Ambiente, conhecida como Conferência de Dublin, realizada em janeiro daquele ano. E o segundo, realizado em junho, foi a Conferência das Nações Unidas sobre o Meio Ambiente e Desenvolvimento, a Rio 92.

A Conferência de Dublin reuniu mais de 500 participantes, estando presentes representantes de mais de 100 países e de 80 organizações e teve como resultado um relatório da conferência e quatro princípios norteadores da gestão da água, expressos na Declaração de Dublin (RIBEIRO, 2008).

Os quatro princípios contidos na Declaração de Dublin, dizem respeito a: 1) a finitude da água doce e a necessidade de abordar sua gestão de modo a considerar as questões sociais, econômicas e ambientais; 2) a necessidade de realizar uma gestão transparente e que envolva a participação dos usuários, técnicos e tomadores de decisão; 3) a identificação da mulher como agente com capacidade para manejar e salvaguardar a água; 4) a atribuição de valor econômico à água (DUBLIN STATEMENT, 1992).

Ribeiro (2008) traz algumas reflexões sobre os princípios acordados na Declaração de Dublin e de seus desdobramentos. Os pontos principais de discussão da conferência dizem respeito às deliberações sobre a proposta de gestão da água na escala de bacias hidrográficas e 
também a condição da água como um bem dotado de valor econômico, levantando inclusive aspectos importantes de justiça ambiental, como desigualdade ao acesso causado pelo pagamento pelo uso da água e pobreza. Outra ideia importante, ainda segundo Ribeiro (2008), foi a proposta de criação de um organismo internacional coordenador da gestão da água em escala mundial (o World Water Council, criado em 1996).

Além disso, um dos pontos importantes dos princípios de Dublin está o reconhecimento da necessidade de participação de diferentes stakeholders para que a gestão da água seja equitativa.

O segundo evento realizado em 1992 foi a Conferência das Nações Unidas sobre Meio Ambiente e Desenvolvimento, também conhecida por Rio 92, Cúpula da Terra ou simplesmente Rio 92, ocorrida no Rio de Janeiro. A reunião teve a participação inédita de mais de 3 mil pessoas, sendo representantes de 172 países e mais de 2 mil representantes de diversas ONGs, ou seja, uma enorme participação da sociedade civil, o que é considerado algo inédito em reuniões promovidas pela ONU até então (ONU, 1997a).

O objetivo desta conferência era ajudar os governos a repensarem o desenvolvimento econômico por meio de caminhos que não poluíssem e destruíssem os recursos naturais do planeta.

Nesse sentido, a conferência lança as bases para uma nova concepção de desenvolvimento, com um clima de cooperação internacional que culmina com os cinco documentos como resultados oficiais: a Declaração do Rio sobre Meio Ambiente e Desenvolvimento (que não menciona o termo água e apresenta uma lista de princípios gerais de comprometimento dos Estados participantes do evento ${ }^{23}$ ); a Declaração sobre Florestas; a Convenção sobre Mudanças Climáticas e a Convenção sobre Diversidade Biológica; e a Agenda 21 (GUIMARÃES; FONTOURA, 2012; ONU, 1997b).

A reunião contou ainda com o Tratado da Água Doce, preparado em um evento paralelo ao oficial organizado pela sociedade civil, que juntou mais de 2 mil ONGs e representantes de movimentos sociais, que entendem que a necessidade da água é condição para a manutenção de todas as formas de vida, ultrapassando a visão antropocêntrica sobre a água. Nesse sentido, para esses grupos sociais, o desafio mais importante está na mudança do

\footnotetext{
${ }^{23}$ Inclui o "princípio das responsabilidades comuns, porém diferenciadas" (princípio 6) e o "princípio da precaução" (princípio 15).
} 
modelo de organização atual, de modo que envolva a participação da sociedade nos diferentes níveis de gestão do recurso (RIBEIRO, 2008).

Alguns dos aspectos presentes neste documento preparado pela sociedade civil também estão presentes na Agenda 21, que ao tratar de variados temas, como cooperação internacional, fortalecimento de grupos sociais e conservação e gestão dos recursos naturais, aborda a questão da água no capitulo 18.

Nesse sentido, o documento demonstra preocupação com as mudanças climáticas e os consequentes eventos extremos de seca e enchentes, além da percepção da necessidade de realização de um modelo de gestão que integre água superficial e subterrânea, o entendimento das diversas finalidades dos usos da água, econômicos ou não, reforçando o uso eficiente e redução do desperdício, uma vez que se considera a água um recurso natural vulnerável e limitado (ONU, 2013a).

As diretrizes da Agenda 21 para a água integram um dos principais orientadores internacionais de planejamento e gestão da água, além de trazer aspectos relacionados ao processo de governança, como a participação da sociedade. É a neste momento que a gestão integrada dos recursos hídricos ganha maior destaque, apesar de já estar presente desde a Conferência de Mar del Plata, em 1977.

Entretanto, ao analisar os resultados da Agenda 21, Ribeiro (2008) ressalta que caso o plano de ação que constava no documento tivesse sido aplicado em grande escala, a situação da água atualmente não seria tão grave como se encontra atualmente em muitas regiões.

O setor empresarial também foi convidado a participar da Rio 92. Assim, surge em 1990 o Business Council for Sustainable Development (BCSD), com participação de 48 líderes, que foram representar o setor empresarial na Conferência da ONU, no Rio de Janeiro em 1992.

O primeiro encontro do BCSD se deu em Haia, em 1991 antecedendo a Rio 92. No ano seguinte, em 1992, é formado o primeiro BCSD nacional, na Argentina. É nesta época que o conceito de eco eficiência começa a ser formulado, se referindo a "criação de valor com menos impacto" (WBCSD, 2013). A ideia de eco eficiência não se restringe à água, mas a todo recurso natural usado na produção de bens e serviços. 
A participação do BCSD na Rio 92 resultou em uma publicação chamada Changing Course: A global business perspective on development and the environment que trata das questões ambientais, empresas e crescimento econômico, aproveitando o momento favorável em relação à discussões ambientais no qual o setor corporativo se encontrava, identificando oportunidades de ganho com a apropriação das questões ambientais.

Até então, os princípios de proteção ambiental eram tidos como restrição ao crescimento econômico, prevalecendo os instrumentos de regulação de caráter reativo (GUIMARÃES; FONTOURA, 2012).

Em 1995 a organização se junta ao World Industry Council for the Environment e se transforma no World Business Council for Sustainable Development (WBCSD), como é atualmente conhecida.

Em março de 1994 acontece, nos Países Baixos, a Conferência de Noordwijk (Conferência Ministerial de Água Potável e Saneamento) que teve como principal objetivo viabilizar a implementação da Agenda 21. O evento contou com representantes de mais de oitenta países, organizações multilaterais e representantes da sociedade civil (CUNHA et al., 2010).

Como resultado da Conferência, obteve-se o Plano de Ação, que contemplava cinco aspectos: 1) água e população, que prevê a participação popular e transparência na gestão da água; 2) água, saúde e ambiente, onde foi sugerida a adoção do princípio poluidor-pagador, além da elaboração de relatórios nacionais com dados sobre saneamento, qualidade de água e doenças de veiculação hídrica; 3) água e instituições, incentivando as instituições locais a participarem da gestão da água, reforçando o papel do Estado como provedor de serviços de saneamento básico e regulador da ação privada nestes setores; 4) água e recursos financeiros, reforçando a necessidade de acesso à água para todos, com recursos financeiros provenientes do pagamento pelos serviços de saneamento, com tarifas mais baixas aos mais pobres; 5) água no mundo, onde expressa o necessário envolvimento dos países e dos organismos multilaterais no desenvolvimento da Agenda 21 e o intercâmbio de experiências de gestão da água entre os países ricos e pobres (RIBEIRO, 2008).

No mesmo ano de 1994, a International Water Resources Association (IWRA) organiza uma sessão especial durante o oitavo Congresso Mundial da Água, no Cairo, que resulta na criação do World Water Council (WWC), implementado oficialmente no ano de 
1996. Seu surgimento emerge do consenso da necessidade de existir uma organização "guarda-chuva" de modo que fosse possível unir os esforços díspares, ineficientes e fragmentados em relação à gestão da água em escala global (WWC, 2013a).

Assim, o WWC é uma plataforma multistakeholder representada por entidades estatais, ONGs, setor privado e agências multilaterais de cooperação (VARGAS, 2005) que pretende funcionar como facilitadora de troca de informações sobre conservação, planejamento e gestão da água em diferentes níveis, a partir do seu principal produto, que são os Fóruns Mundiais da Água (World Water Forum) (WWC, 2013b).

De modo ilustrativo, em março de 2013 o WWC possuía 290 membros, sendo a grande maioria classificados como empresas privadas ${ }^{24}$ (totalizando 105). Do total de membros, 30 deles são brasileiros, sendo seis organizações da sociedade civil e usuários de água, seis instituições acadêmicas e associações profissionais, sete autoridades governamentais e onze empresas (WWC, 2013c).

No mesmo ano da fundação do WWC, 1996, é fundado também o Global Water Partnership (GWP), liderado conjuntamente pelo Banco Mundial e pelo Programa das Nações Unidas para o Desenvolvimento (PNUD) (VARGAS 2005). A base da criação do GWP foram os princípios da Conferência de Dublin e a necessidade de implementação de uma gestão integrada dos recursos hídricos (do inglês Integrated Water Resources Management - IWRM), prevendo a participação da sociedade civil no processo de gestão da água que surgiu durante a Conferência das Nações Unidas para o Meio Ambiente e Desenvolvimento, a Rio 92.

A principal característica do GWP é seu caráter informativo (RIBEIRO, 2008). Seu objetivo é desenvolver um quadro para a aplicação do IWRM, por meio de um comitê de assessoria técnica regional que tem como atividade a sensibilização e o compartilhamento de experiências e práticas na gestão da água, promovendo a gestão sustentável dos recursos hídricos. Diferentes atores fazem parte do GWP, como associações profissionais, instituições de pesquisa, empresas privadas, agências da ONU e governos (GWP, 2013).

No ano de 1997, na cidade de Marrakech, Marrocos, é realizado o I Fórum Mundial da Água (World Water Forum) sob a organização do World Water Council. Este primeiro fórum

\footnotetext{
${ }^{24}$ a classificação dos membros pelo WWC são: Civil Society and water users organizations, Professional associations and academic institutions, Governments and government authorities ou Enterprises and facilities (WWC, 2013).
} 
teve como principal objetivo ampliar a discussão sobre as questões relacionadas à água e definir estratégias para utilizá-la melhor no século XXI, baseadas nos princípios de Dublin e no capítulo 18 da Agenda 21, que aborda a temática da água (MARRAKECH DECLARATION, 1997). Com a participação de representantes de vários países, organismos internacionais e ONGs se iniciou a preparação do documento Vision for Water, Life and Environment, que pretendia juntar informações sobre a situação da água ao redor do mundo e descrevendo quatro cenários possíveis, que dependeriam das decisões políticas, econômicas e sociais (COSGROVE, 2013).

No mesmo ano de 1997 foi organizada a Rio +5, na cidade de Nova Iorque com o intuito de avaliar os efeitos da Rio 92 na implementação dos itens que constavam Agenda 21.

Especificamente em relação ao tema água foram levantadas questões que expressavam preocupação com possíveis conflitos políticos e armados pelo uso da água, problemas com acesso à água, além da compreensão dos efeitos negativos da disponibilidade de água causados pelo desmatamento e uso intenso na irrigação. Ainda, apontou-se para o surgimento de uma crise próxima (o documento cita o ano de 2025), caso os padrões de uso e gestão da água não fossem alterados. Foi reforçada também a necessidade de cooperação e financiamento internacional de transferência tecnológica de programas que ampliem os serviços de saneamento básico (abastecimento de água e coleta e tratamento de esgoto), principalmente em áreas urbanas e peri-urbanas de regiões pobres.

Mesmo com estes desafios apontados, houve quem defendeu que em relação às florestas, ecoeficiência e água, poderiam ser notados alguns avanços (ONU, 1997b).

Em março do ano seguinte, em 1998, foi promovida pela UNESCO a Conferência Internacional de Água e Desenvolvimento Sustentável, conhecida como Conferência de Paris, já que ali ocorreu. Os apontamentos presentes em sua declaração final são baseados nos princípios das Conferências de Mar del Plata (1977), de Nova Delhi (1990), Dublin (1992) e Noordwijk (1994), guiadas pelas conclusões da Rio 92, especialmente do capítulo 18 que trata do tema água (INTERNATIONAL CONFERENCE ON WATER AND SUSTAINABLE DEVELOPMENT, 1998).

Conceitos como poluidor-pagador e usuário-pagador, bem como a compreensão de que a água possui valor econômico, social e ambiental são novamente ressaltados. Ainda, se reforça a necessidade da realização de uma gestão da água de modo participativo e integrado, 
tendo como unidade de gestão a bacia hidrográfica. Ainda, reconhecem que problemas relacionados à água como seca, enchentes, poluição, falta de infraestrutura e escassez, por exemplo, podem comprometer o desenvolvimento social e econômico, a saúde humana, a segurança alimentar e a qualidade ambiental (INTERNATIONAL CONFERENCE ON WATER AND SUSTAINABLE DEVELOPMENT, 1998).

Apesar de ter reunido representantes de mais de 80 países, a Conferência de Paris não contribuiu muito para o avanço do debate internacional sobre água (RIBEIRO, 2008).

No ano 2000, durante o II Fórum Mundial da Água, realizado em Haia, Holanda, foi apresentado o documento World Water Vision, proposto durante o I Fórum Mundial da Água. O documento apresenta a situação dos recursos hídricos naquele momento e tenta prevê a situação no ano de 2025.

De acordo com o relatório, os usuários não valorizam a água e a desperdiçam porque pagam muito pouco (ou não pagam) por ela. Ainda, afirma que se as tecnologias capazes de melhorar a eficiência dos processos fossem mais difundidas, haveria uma diminuição do consumo e dos efeitos sobre sua qualidade. Deste modo, defende que deve haver um limite para a expansão da agricultura irrigada e que a produtividade da água deve ser maximizada. Também considera que as instituições que administram os recursos hídricos devem ser reformadas e a inovação tecnológica deve ser incentivada (COSGROVE; RIJSBERMAN, 2000).

Essa é uma maneira de analisar a situação. Porém, considerando que a população mundial aumenta, cresce também a demanda por água e energia para a produção de bens e serviços. Nesse sentido, o aumento da produtividade da água, por exemplo, só teria impacto positivo na pressão sobre a disponibilidade de água caso houvesse um controle na quantidade de bens produzidos ou se a redução do consumo de água pelo aumento da sua produtividade fosse maior que o aumento do consumo resultante do aumento da população.

Assim, é possível perceber nos temas discutidos no II Fórum Mundial da Água, que questões sobre a globalização, comércio e privatização de serviços de água emergem neste evento.

O II Fórum Mundial da água contou com a participação de 5.700 pessoas e teve como resultado a Declaração de Haia, fruto da Conferência Ministerial na qual estavam representados 130 países (WWC, 2013d). Além disso, também foi apresentado o documento 
Towards Water Security: A framework for action, preparado pelo Global Water Partnership (GWP), que estabelece uma estrutura base de ação para alcançar os pontos indicados no informe World Water Vision. A elaboração de ambos os documentos teve a participação de milhares de atores, incluindo representantes de agências governamentais, técnicos, organizações da ONU, setor privado e outros (GWP, 2000).

Ainda no ano 2000, no mês de setembro, reuniram-se em Nova Iorque, na sede da Organização das Nações Unidas, mais de 180 chefes de Estado que se comprometeram em adotar medidas presentes na Declaração do Milênio, cujo objetivo é reduzir a extrema pobreza e alcançar uma série de metas até 2015. Essas metas ficaram conhecidas como os "Objetivos de Desenvolvimento do Milênio" (ODM) e dos oito objetivos, seis deles tem relação com as crianças (UNICEF, 2013). O tema água é um subitem abordado no objetivo 7, que trata da sustentabilidade ambiental. Entretanto, o foco dado à questão da água está relacionado diretamente com o acesso à água potável e serviços de saneamento básico, mas também indiretamente quando se propõe a redução de favelas (ONU, 2013b).

Em 2002 a campanha para apoiar e inspirar as pessoas ao redor do mundo começou e em 2005 o economista Jeffrey Sachs apresentou para o secretário geral da ONU a publicação "Investing in Development: A Practical Plan to Achieve the Millennium Development Goals.", na qual apresenta uma série de recomendações para que fossem alcançados os ODM.

A Conferência de Bonn, realizada na Alemanha em dezembro de 2001, teve como tema “Água: chave para o desenvolvimento sustentável” e teve presença de mais de 118 países, 47 organizações multilaterais e 73 organizações da sociedade civil e foi o maior evento preparatório para a Conferência das Nações Unidas de Johanesburgo (conhecida como Rio+10), realizada no ano seguinte. Apesar disso, a Conferência não trouxe muitos avanços e os pontos já anteriormente discutidos em outras reuniões e conferências voltaram a surgir, como descentralização, cooperação e governança (RAHAMAN et al., 2004).

Nesta conferência, assim como em outros encontros, o setor privado é mencionado como alternativa para melhorar a gestão da água ao fornecer recursos financeiros, por meio de parcerias público-privadas. Dada a condição de escassez da água, há uma tendência em introduzir uma visão de mercado para seu acesso e uso (RIBEIRO, 2008).

Os pontos-chave da Conferência de Bonn foram governança; gestão e parcerias; mobilização de recursos financeiros; compartilhamento de conhecimento. Segundo o relatório 
da conferência, uma boa gestão integrada dos recursos hídricos é importante e há necessidade de avanços em todos os níveis. Entretanto, concluem que somente gerir o recurso corretamente não será suficiente para atingir o objetivo do milênio de garantir acesso à água a todas as pessoas. É necessário que haja tomada de consciência política e pública para alcançar a meta de acesso universal à água (INTERNATIONAL CONFERENCE ON FRESHWATER, 2001).

No ano seguinte, em 2002, aconteceu em Johanesburgo, África do Sul, a Conferência das Nações Unidas sobre Desenvolvimento Sustentável, conhecida como Rio+10 que reuniu mais de dez mil pessoas, incluindo representantes de países, ONGs, setor privado e movimentos sociais. $\mathrm{O}$ intuito deste encontro era avaliar as conquistas e também identificar desafios e novas questões desde a Rio 92 (ONU, 2013c).

Algumas das principais conclusões acordadas na Conferência de Johanesburgo vão ao encontro das metas propostas nos Objetivos de Desenvolvimento do Milênio, como acesso à água potável e energia, e erradicação da pobreza, mas também consideram que é necessário mudar os padrões de consumo e produção, ressaltando a necessidade de atuação nos diferentes níveis. Sobre água foi proposto que fosse desenvolvida uma gestão integrada dos recursos hídricos e planos de eficiência no uso da água até 2005 (JOHANNESBURG SUMMIT, 2002).

No documento final da Conferência de Johanesburgo, é mencionada a responsabilidade das empresas em promover a evolução das comunidades e uma sociedade equitativa e sustentável (JOHANNESBURG SUMMIT, 2002).

Ainda, reforçam a necessidade de ferramentas de avaliação e monitoramento do uso dos recursos naturais, de modo que os impactos socioambientais sejam diminuídos, como avaliação de ciclo de vida dos produtos. Além disso, preconiza-se a internalização dos custos ambientais das atividades econômicas, a transparência e o envolvimento e diálogo entre os diferentes stakeholders na tomada de decisão (ONU, 2002).

Entretanto, Guimarães e Fontoura (2012) ressaltam que a Rio + 10 não acrescentou nada ao regime internacional de meio ambiente e que muito pouco se avançou em relação à Rio 92, a ponto de questionarem sua realização. Os autores atribuem o fracasso da conferência ao otimismo de se considerar que o mundo poderia definir um plano de ação comum, quando os graus de governança do sistema ONU é ainda frágil. E ao mesmo tempo, 
relacionam o insucesso do encontro ao pessimismo de não se elaborar previamente uma agenda com decisões específicas e perder-se muito tempo discutindo pontos fundamentais acordados na Rio 92, como o "princípio das responsabilidades comuns, porém diferenciadas" e o "princípio da precaução", questionados por países desenvolvidos.

No ano seguinte, em 2003, é criada a ONU Água (UN Water, em inglês), uma interagência da Organização das Nações Unidas que funciona como um mecanismo de coordenação para todas as questões relacionadas à água e saneamento do sistema ONU (UN WATER, 2013a).

Nos dez anos de sua atuação, vários relatórios foram publicados trazendo informações sobre questões relacionadas à água. Destacam-se o World Water Development Report (WWDR), o Global Analysis and Assessment of Sanitation and Drinking-Water (GLAAS) e o Joint Monitoring Programme for Water Supply and Sanitation (JMP Updates), em parceria com a OMS e o Fundo das Nações Unidas para a Infância (UNICEF em inglês).

O WWDR é um relatório trienal que busca compilar informações sobre o estado, o uso e a gestão da água ao redor do mundo. Até hoje, foram publicadas quatro edições deste relatório - 2003, 2006, 2009, 2012 - com diferentes enfoques. A partir de 2014 passará a ser anual.

O GLAAS é um relatório bienal que desde 2008 provê informações globais sobre políticas, arranjos institucionais e recursos humanos sobre financiamento em serviços de saneamento básico. Já o JMP Updates apresenta os resultados do monitoramento do Objetivo para o Desenvolvimento do Milênio, que é reduzir pela metade até 2015 o número de pessoas sem acesso à água potável e saneamento básico.

Além dos relatórios e reunião de informações, a ONU Água também realiza campanhas de conscientização sobre água e saneamento, com apoio de membros, programas e parceiros interessados. Como exemplo, pode-se citar o famoso Dia Mundial da Água, celebrado desde 1993 no dia 22 de março, que a cada ano traz um tema com forte relação com a água, como segurança alimentar em 2012 ou energia, tema de 2014.

Ainda, neste mesmo ano a Assembleia Geral da ONU estabelece 2003 como o "ano internacional da água doce", com intuito de ampliar a consciência sobre a importância do uso sustentável da água, contando com o envolvimento do setor público, privado, ONGs e outras 
organizações para contribuírem de maneira voluntária com medidas que apoiem o ano internacional da água doce.

O III Fórum Mundial da Água ocorreu no Japão, em 2003, onde reuniu 24 mil participantes, com representantes de 170 países. Temas como o direito universal da água, financiamento e investimento em serviços de água e saneamento, estiveram presentes nesta edição do evento. Entretanto, ganhou destaque a discussão sobre a participação do setor privado, principalmente por meio de parcerias público-privadas para provisão de abastecimento de água e também aspectos relativos à governança da água, enfatizando a necessidade de um quadro institucional e legal forte e transparente (WWC, 2004).

A Assembleia Geral da ONU aprovou em 2003 a década de ação "Water for Life", de 2005 a 2015, com intenção de promover esforços que permitam comprometimento internacional com questões relacionadas à água, de modo que a cooperação em todos os níveis se amplie, principalmente no continente africano. A ideia de criar a década "Water for Life" começa em 2000, com os Objetivos de Desenvolvimento do Milênio, contribuindo assim para a ampliação do acesso à água potável, tema discutido em 2002 durante a Conferência de Johanesburgo e presente na Agenda 21 (ONU, 2013d).

A década "Water for Life" relaciona questões entre a água e assuntos que vão além do direito ao acesso a saneamento, financiamento e gênero, geralmente temas mais discutidos nas reuniões da ONU. Deste modo, propõe discutir a água pela perspectiva de sua qualidade, quantidade e escassez, pelo viés da segurança alimentar e da economia.

Além destas abordagens, considera a água nas cidades, já que grande parte da população mundial vive em áreas urbanas, tema de grande complexidade quando se pensa sobre gestão integrada, cooperação e processos de governança.

No ano de 2006 há a IV edição do Fórum Mundial da Água, organizado pelo World Water Council no México, sob o tema "Local Actions for a Global Challenge". Este encontro teve aproximadamente 20 mil pessoas e tendo a participação de representantes de 140 países (WWC, 2013e). Na Declaração Ministerial desta reunião, é reafirmada a importância da água como aspecto fundamental para o desenvolvimento sustentável, o comprometimento com os objetivos de uma gestão integrada dos recursos hídricos, Agenda 21 e Objetivos de Desenvolvimento do Milênio. Ainda, reconhece o importante papel de autoridades locais para apoiar a gestão integrada da água e também políticas nacionais e internacionais que cooperem 
e construam capacidades mitigatórias para desastres relacionados à água, atuando na prevenção, avaliação de risco, consciência comunitária, resiliência e respostas (FOURTH WORLD WATER FORUM, 2006).

Em 2008, é criada a Alliance for Water Stewardship (AWS), organização multistakeholder sem fins lucrativos que tem como objetivo promover o uso responsável da água trazendo benefícios sociais e econômicos, além de ser ambientalmente sustentável. Fazem parte do corpo da AWS várias organizações como The Nature Conservancy (TNC), WWF, European Water Partnership, UN Global Compact CEO Water Mandate, Carbon Disclusure Project (CDP), PNUMA, da ONU, entre outros. Há também um comitê técnico. Os membros que compõem a AWS fazem parte do setor privado, setor público e também da sociedade civil (AWS, 2014a).

Inspirada no Forest Stewardship Council (FSC), uma certificação de produtos de origem florestal, a AWS lançou em abril deste ano seu Standard que pretende certificar empresas a partir de um conjunto de critérios e princípios como governança, melhoria do balanço hídrico e qualidade da água, e por fim, proteção de áreas importantes em relação à água (AWS, 2014b).

Assim como o FSC, a proposta da certificação da AWS é inserida em outra forma de governança, conhecida por governança não estatal dirigida pelos mercados (VOIVODIC; BEDUSCHI, 2011; CASHORE, 2002), de maneira que os problemas coletivos em relação à água sejam solucionados ou minimizados e que a empresa receba um selo pelo seu esforço. Esta certificação acaba sendo legitimada pelos stakeholders de diferentes segmentos que compõem o corpo da AWS.

Essa iniciativa surge, uma vez que, de acordo com a AWS, somente políticas de água são insuficientes para enfrentar problemas como qualidade e quantidade disponível de água ou perda de biodiversidade, e seus riscos associados. Deste modo, sugerem que ações intersetoriais devem ser tomadas de modo a incentivar que os grandes usuários de água se posicionem e atuem em prol da melhora e manutenção das condições hídricas.

Também em 2008, foi formada a Water Footprint Network, plataforma que visa conectar várias comunidades interessadas na sustentabilidade, equidade e eficiência no uso da água, que surgiu a partir do grande interesse pelo conceito de Pegada Hídrica, desenvolvido 
pelo Prof. Arjen Hoekstra, da Universidade de Twente, Holanda (HOEKSTRA; HUNG, 2002; WFN, 2014a).

O conceito de Pegada Hídrica está relacionado com os impactos causados aos sistemas aquáticos pelo modo de vida e consumo humano. Isso significa considerar a poluição e o consumo de água a partir do sistema produtivo como um todo, ou seja, pela perspectiva da estrutura econômica vigente (WFN, 2014a). Esta perspectiva de análise traz a água como um recurso global e que melhorar a sua gestão pode ter a participação de empresas, governos, ONGs e consumidores, por exemplo, por meio da avaliação da Pegada Hídrica de produtos, empresas, cidades a até países.

É interessante observar que a Water Footprint Network disponibiliza gratuitamente na sua página na Internet dados, artigos científicos e relatórios referentes à aplicação da Pegada Hídrica em diferentes escalas, além do manual de avaliação da Pegada Hídrica que traz as fundamentações e orientações para realizar a avaliação da Pegada Hídrica.

A WFN tem atua oferecendo treinamento para aplicar a avaliação da Pegada Hídrica, ampliar a conscientização dos diferentes setores sobre o uso eficiente da água, reduzindo os impactos a ele associados, além de atuar no desenvolvimento do indicador (WFN, 2014a).

Organizações de diferentes setores são parceiras da rede WFN. Destacam-se, por exemplo, Natura, Fibria, Coca-Cola, Nestlé, SABMiller e Pepsico, do setor corporativo; universidades e centros de pesquisa, como a Universidade de Twente (Holanda), USP (Brasil), Universidade de Zaragoza (Espanha) e Universidade de Tóquio (Japão); organizações não governamentais, como WWF e TNC; organismos internacionais, por exemplo, International Finance Corporation (grupo do Banco Mundial), WBCSD e UNESCO-IHE (Institution for Water Education); e também algumas empresas de consultorias (WFN, 2014b).

Em 2009, acontece em Istambul, Turquia, a quinta edição do Fórum Mundial da Água, que teve mais de 17.400 pessoas inscritas de 182 países. O tema da reunião era a “conciliação" entre os diferentes modos de entender e atuar em relação à água, que necessitam ser revistos e repensados (WWC, 2014).

De acordo com o presidente do World Water Council, Läic Fauchon, soluções técnicas não são suficientes para resolver as questões relacionadas à água, havendo a necessidade de reconhecer que no nível local muitos atores tem capacidade de atuar frente aos desastres, o 
que significa que devem ser integrados às instâncias de gestão ambiental. Ainda, foi discutido o nexo água-alimento-energia, de modo que as políticas passem a ser integradas e multifuncionais para alcançar o melhor uso dos recursos naturais disponíveis, indicando a necessidade de mudar a maneira setorial de compreender as questões relacionadas à água (WWC, 2009a).

O assunto financiamento teve muito mais atenção nesta edição do fórum do que havia tido anteriormente, obviamente pelo contexto econômico mundial daquele período, logo após a crise de 2008. Mas, apesar da crise financeira, defendeu-se também que era possível se aproveitar dela por meio do aumento da eficiência e inovação da gestão dos recursos hídricos (WWC, 2009b).

Como resultado do encontro, um guia foi elaborado para alcançar os desafios globais em relação à água que inclui a implementação da gestão integrada dos recursos hídricos (IWRM) e a produção e compartilhamento de informações para prevenir os desastres naturais (WWC, 2009a).

Outro produto resultante do encontro foi o Istambul Water Consensus, que teve 58 signatários comprometidos com a adaptação da infraestrutura dos serviços de água para enfrentar desafios advindos com as mudanças do clima, crescimento urbano e piora da qualidade da água (ISTAMBUL WATER CONSENSUS, 2009).

No ano de 2012 ocorreram dois grandes eventos mundiais. Em março, houve a sexta edição do Fórum Mundial da Água, na cidade de Marselha, França. Já em junho aconteceu a Rio + 20, Conferência das Nações Unidas sobre o Desenvolvimento Sustentável, no Rio de Janeiro.

O $6^{\circ}$ Forum Mundial da Água teve 145 países representados por chefes de Estado, Ministros, vice-Ministros ou secretários de Estado, 3.500 ONGs e outras organizações da sociedade civil, registrando no total 35 mil participantes (WWC, 2014a).

Sob o tema "Tempo de Soluções", o $6^{\circ}$ Fórum Mundial da Água teve 12 mesasredondas, algumas antecipando temas que seriam discutidos posteriormente, durante a Rio + 20. As mesas redondas falavam de adaptação às mudanças climáticas, crescimento e economia verde, financiamento de infraestruturas, águas transfronteiriças, temas técnicos, como dessalinização e tratamentos de efluentes e sua relação com segurança hídrica, nexo água-alimento-energia e desastres com relação à água (WORLD WATER FORUM, 2012). 
Cabe ressaltar que a eficiência no uso da água é apontada como resposta frequente para enfrentar os problemas relacionados à água.

Como as soluções faziam parte da proposta do evento de 2012, diferentes propostas, acordos, colaborações foram firmadas por diferentes atores, como universidades, agências multilaterais, governos, ONGs, instituições financeiras e diferentes associações. As ações foram divididas em quatro eixos estratégicos principais, contendo diferentes prioridades em cada um deles.

As quatro direções estratégicas foram: 1) garantia de bem estar para todos, com prioridades em relação a acesso e direito a água e saneamento, melhora da saúde por meio de serviços de água e saneamento, prevenção e resposta aos riscos atrelados à água e crises, e finalmente, contribuição com cooperação e paz através da água; 2) contribuição com o desenvolvimento econômico, com prioridades definidas em balancear os múltiplos usos da água, contribuir com a segurança alimentar por meio do uso ótimo da água, harmonizar água e energia, promover crescimento verde e valorar os serviços ecossistêmicos; 3) manter o planeta "azul”, com as seguintes prioridades: melhorar a qualidade da água e dos ecossistemas, ajustar a pressão e a pegada hídrica das atividades humanas ${ }^{25}$, responder às variações climáticas globais em um mundo globalizado; 4) criação de condições para avançar, com prioridades como boa governança, financiamento de água para todos e práticas educativas (WORLD WATER FORUM, 2012).

Cada umas das prioridades definidas possui diferentes ações coordenadas por uma instituição, com prazos e metas. Além disso, observa-se que não há propostas de tentem algum tipo de mudança estrutural, que questione o atual modelo socioeconômico e suas consequências para os ambientes aquáticos. Ao contrário, são observadas ações que mantêm o mesmo modo de pensar e enfatizar o componente econômico como convencionalmente é feito, sem propor nenhuma mudança estrutural.

Apesar destas considerações, é notável o esforço da iniciativa de reunir atores e propor soluções com prazos e metas estabelecidos, fora do sistema ONU. O fato de haver coordenadores de cada ação amplia o comprometimento e a responsabilização para com os

\footnotetext{
${ }^{25}$ Uma das ações dentro desta prioridade é a elaboração de banco de dados com Pegadas Hídricas globais e mapas e está sendo coordenada pela Water Footprint Network. Outra ação, coordenada pela Alliance for Water Stewardship, é até 2015 vinte das maiores empresas mundiais desenvolverem estratégias de mitigação de suas $\mathrm{PH}$ e obterem certificações de uso sustentável da água.
} 
resultados. Espera-se que no próximo Fórum Mundial da Água, que será realizado em 2015, seja possível encontrar avanços nas questões identificadas como estratégicas.

O outro grande evento de 2012 foi a Rio + 20, realizada no Rio de Janeiro, que teve a atenção do mundo todo como promessa de uma possível mudança no sentido de colocar em prática as soluções para os problemas em relação às cidades, água, energia, alimentação, pobreza e ecossistemas por meio de dois temas principais: a transição para uma economia verde e governança internacional, ambos como caminho para alcançar o desenvolvimento sustentável, conceito consensuado anteriormente, na Rio 92 (ONU, 2012).

A proposta era fazer uma avaliação dos avanços em relação à Rio 92, além de renovar e atualizar o acordo feito vinte anos atrás já que o contexto político mundial sofreu mudanças desde aquela época. Assim, mesmo com a forte influência norte-americana na política internacional, os efeitos da crise iniciada no sistema financeiro em 2008 e a emergência de alguns países como importantes atores globais, como China, Brasil, Rússia, África do Sul e Índia caracterizam um cenário internacional diferente daquele que havia em 1992, marcado pela dissolução da União Soviética (MEDEIROS, 2012).

Como resultado concreto, Viola e Franchini (2012) apontam que o Fórum das Grandes Cidades foi o único acordo internacional substantivo entre atores relevantes ${ }^{26}$ com propósito de diminuir as emissões de carbono.

Ainda, conferência contou com diferentes eventos paralelos organizados pela sociedade civil, a chamada Cúpula dos Povos, e também pelo setor corporativo.

Este último se organizou em um evento ${ }^{27}$ liderado pela ONU Global Compact $^{28}$, que culminou em um documento que reconhece a importância da sustentabilidade corporativa para avançar na agenda do desenvolvimento sustentável. Como sustentabilidade corporativa o documento considera a criação de valor em longo prazo, em termos financeiros, sociais, ambientais e éticos (CORPORATE SUSTAINABILITY FORUM, 2012).

Dentre diferentes temas socioambientais, o documento aponta caminhos para que todas as empresas possam implementar uma agenda na qual incluam práticas sustentáveis que transformem o mercado em um verdadeiro contribuinte melhora das condições ambientais.

\footnotetext{
${ }^{26} 56$ das principais cidades do mundo representando países importantes (VIOLA; FRANCHINI, 2012).

27 Corporate Sustainability Forum, realizado entre 15 e 18 de junho.

${ }^{28}$ Iniciativa da ONU para engajar o setor corporativo para diferentes temas, incluindo a questão da água.
} 
Menciona-se também a influência que outros stakeholders podem exercer nesta trajetória, como investidores, bolsa de valores e universidades, e pressionam ainda apoio e clareza de direcionamento por parte dos governos.

Com relação à água e ecossistemas, além da questão do desenvolvimento de tecnologias para melhorar a eficiência no uso da água, principalmente nas atividades agrícolas, se incentiva que as empresas contabilizem a Pegada Hídrica de toda a sua cadeia produtiva.

Além disso, como sugestões de inovação, o documento final do Corporate Sustainability Forum recomenda que sejam desenvolvidos produtos e serviços sensíveis a água: com o aprimoramento do método de avaliação da Pegada Hídrica, as empresas, ao avaliarem a pressão ao sistema hídrico causada pelo consumo de água de seus processos produtivos completos, podem investir, por exemplo, em roupas que consumam menos água para serem produzidas, ou ainda produtos de limpeza, como detergentes, ou higiene pessoal, como xampus, condicionadores e sabonetes, que tenham menor necessidade de água para serem usados ou cultivos agrícolas que utilizam menos água.

Outros pontos levantados são sobre a realização de investigações e desenvolvimento de informações e análises locais e globais a respeito da água. E também sobre a valoração de ecossistemas e de capital natural com objetivo de internalizar os custos e impactos negativos repassados aos ecossistemas e sociedade. As ações se baseiam no argumento principal de que é preciso atuar estrategicamente para enfrentar os riscos atrelados à água.

Apesar de a declaração do Secretário-Geral da ONU, Ban Ki-moon, assegurar que a Rio+20 foi um sucesso, com a participação de 100 chefes de Estado e ampla participação da sociedade civil e setor empresarial, a avaliação de especialistas na área socioambiental não foi muito positiva (FRIENDS OF THE EARTH INTERNATIONAL, 2012; GREENPEACE, 2012).

Um fator fundamental diz respeito à falta de compromissos e de iniciativas por parte dos governos. Parte das frustrações refere-se à perda da possibilidade de colocar em prática as alternativas encontradas há muito tempo sobre as profundas mudanças necessárias em relação ao combate à pobreza e nas relações com a natureza (GUIMARÃES; FONTOURA, 2012; VIOLA; FRANCHINI, 2012). 
Para Guimarães e Fontoura (2012), o fato de não haver tido, durante os preparativos do encontro, previsões de decisões de Estado na forma de tratados ou acordos multilaterais de caráter legalmente vinculante fez com que a Rio + 20 tivesse uma agenda modesta, apenas com discussões "quase acadêmicas" sobre economia verde e governança internacional, reforçado por ausências relevantes, como a do presidente dos Estados Unidos.

Além disso, não houve avanços significativos na criação de um mecanismo de governança ambiental global e tampouco acordo consistente sobre a definição do conceito de economia verde. Para agravar a situação, foi negligenciado o debate sobre a situação física do planeta, ou seja, dos limites dos recursos naturais, cada vez mais respaldado cientificamente (VIOLA; FRANCHINI, 2012).

Retomando a questão da água, 2013 foi declarado como o Ano Internacional de Cooperação pela Água pela ONU, com objetivo de chamar a atenção para os benefícios trazidos pela cooperação na gestão da água, considerando que 148 países compartilham pelo menos uma bacia hidrográfica e que este fato é causa de conflitos pelo seu uso. Deste modo, com eventos mundiais, como a Conferência sobre Cooperação pela Água no Tajiquistão ou Cúpula da Água em Budapeste, pretendeu-se divulgar exemplos bem sucedidos de cooperação pela água, explorando questões centrais, como diplomacia, gestão de bacias transfronteiriças e cooperação financeira (UNESCO, 2013). Além disso, foram discutidos os objetivos para o desenvolvimento sustentável em relação à água, agenda para depois de 2015 , em substituição aos objetivos do milênio para o desenvolvimento (UNITED NATIONS WATER, 2013a).

As principais conclusões sobre o Ano Internacional de Cooperação pela Água serão reunidas para fornecer contribuições para o próximo Fórum Mundial da Água, que será realizado em 2015 na Coreia do Sul (BUDAPEST WATER SUMMIT, 2014).

Para finalizar o resgate histórico sobre a agenda internacional da água, cabe ressaltar a semana mundial da água, World Water Week, realizada anualmente em Estocolmo, Suécia, desde 1991 pelo Stockholm International Water Institute (SIWI). A cada ano o evento trata de um tema particular e reúne atores de diferentes setores para discutir as questões relacionadas à água. A última edição até o momento, realizada em setembro de 2013, tinha como tema a cooperação e parcerias para a água. Já o encontro de 2014 terá como foco a relação água e energia (WORLD WATER WEEK, 2014). 


\subsection{O histórico da agenda global da água sob a perspectiva da modernização ecológica}

A partir do resgate histórico da discussão internacional sobre a água apresentado anteriormente, é possível observar que até início dos anos 2000, as iniciativas da ONU lideraram a sua discussão em âmbito internacional.

Até meados da década de 1990, o resultado, conforme descrito, foi a ocorrência de inúmeras conferências sob sua responsabilidade, defendendo principalmente o acesso à água $\mathrm{e}$ serviços de saneamento.

A partir da Conferência de Dublin (1992) e Rio 92, com a Agenda 21 (capítulo 18) percebe-se a inclusão das questões sobre a descentralização dos processos de tomada de decisão em relação à água, governança e participação de todos os usuários.

Nesse sentido, a Rio 92 deixa uma profunda marca, principalmente na sociedade brasileira, aumentando a conscientização da sociedade sobre as questões ecológicas, ao questionar o modelo adotado de produção e consumo e suas implicações socioambientais (VIOLA; FRANCHINI, 2012).

Ao mesmo tempo em que a Rio 92 fortalece a participação da sociedade civil, nota-se que é a partir desta conferência que o setor corporativo entra nas discussões sobre meio ambiente, e consequentemente sobre água.

Isso se dá por meio da organização do setor corporativo para participar da Rio 92, ao mesmo tempo que identifica na questão ambiental uma oportunidade de ganho financeiro e vantagem competitiva, indicando a sobreposição da racionalidade econômica sobre a racionalidade ecológica (PORTER; LINDE, 1995).

É interessante relembrar que esse movimento no qual as empresas passam a participar nos espaços de discussão sobre as questões ambientais acontece na década de 90, ao mesmo tempo em que a responsabilidade social corporativa (RSC) é adotada como estratégica para as empresas (HOFFMAN, 1997), que começam a ser contestadas sobre os impactos ambientais negativos causados por suas atividades e, mais recentemente, sobre o papel e responsabilidade das empresas e mercados como agentes sociais (ABRAMOVAY, 2012). 
Do mesmo modo, observa-se que os assuntos tratados nas reuniões e conferências sobre água descritas anteriormente, apesar de terem se tornado repetitivos ${ }^{29}$, poucos resultados foram alcançados (RIBEIRO, 2008), principalmente naquelas organizada pela ONU, o que demonstra a incapacidade da arquitetura institucional desse sistema para promover avanços consistentes no plano intergovernamental (VIOLA; FRANCHINI, 2012).

Portanto, a partir das previsões dos impactos negativos das alterações climáticas sobre o ciclo hidrológico, o setor corporativo, como um usuário de água, mais recentemente identifica que a água pode se tornar um risco para a continuação de suas atividades (HEPWORTH, 2012; MORRISON et al., 2010) e passam a se organizar e elaborar iniciativas que evitem que sua atuação seja contestada e tenha prejuízos.

O contexto de fragilidade da governança internacional global, a dominância da racionalidade econômica e o estímulo para que todos os atores e setores econômicos atuem em prol da melhoria das condições ambientais, configura um ambiente propício para o surgimento de ferramentas e iniciativas que abordem a questão da água, como a PH, e que possam ser utilizadas principalmente por empresas, a partir do final dos anos 2000.

Assim, o que se observa é que além do World Business Council for Sustainable Development (WBCSD), outros arranjos que possuem grande influência do setor corporativo foram formados a partir da metade dos anos 90. Um deles é o World Water Council (WWC), que organiza a cada três anos o Fórum Mundial da Água, e outro exemplo é o Global Water Partnership (GWP).

Isso significa que o setor corporativo ouviu o chamado para participar das discussões em relação à água e, atualmente, são as principais organizações que lideram as discussões sobre as questões relacionadas à água além da ONU, que tem encontrado dificuldade em comprometer seus membros com ações efetivas.

Barlow $^{30}$ (2009) considera que o interesse do setor empresarial pela água vem em primeiro lugar por serem usuários de água, necessária para as suas atividades econômicas, mas também, em alguns casos, pela privatização dos serviços de água e saneamento, comum nos países do norte e imposta nos países do sul, que passam a ser vistos como oportunidade de

\footnotetext{
29 Por exemplo: participação, descentralização, financiamento, cooperação internacional, eficiência e infraestrutura.

${ }^{30}$ Maude Barlow é chefe do Council of Canadians, organização de militância pública, e tem vários livros e artigos sobre justiça hídrica.
} 
negócios, apoiado pelo Banco Mundial. Ou seja, é um outro nicho de atuação onde o setor corporativo pode enriquecer, segundo ela.

Deste modo, a possibilidade de lucro por parte das empresas que se comprometem com as questões ambientais significa que o crescimento econômico não precisa ser um entrave para a proteção dos recursos naturais, como aponta as ideias da TME (MOL; SPAARGAREN, 2000a).

Por esta razão, é possível observar que os tópicos sobre eficiência no uso, valor econômico da água e infraestrutura são cada vez mais frequentes em muitas das reuniões ocorridas a partir de meados da década de 1990. Geralmente, são apontados como estratégicos para enfrentar os desafios de manter água em quantidade e qualidade mínimas para todos os usos.

De acordo com Barlow (2009), tanto o WWC como o GWP, apoiados pelo Banco Mundial e ONU, defendem o papel do setor privado na gestão e provisão de água e serviços de saneamento. Nesse sentido, ela acredita que são organizações que ao invés de discutir, pretendem ditar a política mundial da água.

Rosa Mancini, que representou a Secretaria de Meio Ambiente do Estado de São Paulo no WWC, reforça que, apesar de ser um espaço de discussão, a construção das agendas do WWC e do GWP não são abertas. Ao contrário, ela vem pronta e tem o discurso e assuntos técnicos como dominantes, em detrimento aos aspectos socioambientais em relação à água, que geralmente são esquecidos. Ela ressalta também que a força e frequência dos assuntos técnicos podem ter relação com as empresas que subsidiam as ações de ambas as instituições, geralmente empresas de saneamento que tem interesses na privatização destes serviços (informação verbal ${ }^{31}$ ).

Estas afirmações corroboram com a análise feita por Barlow (2009), que traz uma série de informações sobre a relação de empresários e estas organizações.

Analisando as prioridades levantadas até a década de 90, é possível perceber ênfase no discurso técnico e científico, marcado por temas como infraestrutura, eficiência e controle da poluição, por exemplo. Ou seja, fortemente marcado pelos agentes principais da reforma ambiental presentes no início do desenvolvimento da teoria da modernização ecológica

\footnotetext{
${ }^{31}$ Informações obtidas em conversa realizada em 18/12/2013 e por e-mail em 14/05/2014.
} 
(TME), no início dos anos 80: otimismo tecnológico, forças de mercado atuando e manutenção das instituições modernas (MOL; SPAARGAREN, 2000b).

É o que Hajer (1995) denomina como a variante tecnocorporativista da modernização ecológica ou ainda modernização ecológica fraca (ou seja, econômico-tecnológica), na concepção de Christoff (1996).

Com o passar do tempo, a TME amadurece e emerge a discussão sobre o papel do Estado e sua relação com o mercado na busca da melhoria da qualidade ambiental. Assim, a discussão passa a ser a inclusão de todos os agentes econômicos como corresponsáveis para atuar na reforma ambiental e também reflexões sobre a mudança na forma de atuação do Estado, de forma mais descentralizada, participativa, preventiva e flexível (MOL; JÄNICKE, 2000; MOL, 2010).

Desta forma, a ampliação da participação de diferentes stakeholders nos processos de tomada de decisão, a criação de novos arranjos e arenas de participação visando a cooperação na elaboração de políticas ambientais são incorporados como necessários para a reforma ambiental (BUTTEL, 2003).

Estas características formam parte da variante reflexiva da modernização ecológica, retomando Hajer (1995) ou modernização ecológica forte (ou institucional-democrática), para Christoff (1996).

Sob o argumento de impulsionar uma economia verde, o setor privado novamente se organiza na Rio +20 , em 2012, reconhecendo a importância da sustentabilidade corporativa para se avançar na reforma ambiental.

É claro que é importante e necessário o setor empresarial assumir publicamente seu papel como agente capaz de contribuir com a melhoria das condições socioambientais em relação à água, minimizando os impactos negativos causados nos locais de suas atividades. Porém, é preciso uma análise crítica sobre os caminhos que serão escolhidos para isso.

No documento final resultante da conferência do setor corporativo na Rio +20 , é mencionado que deve haver constante inovação tecnológica que melhorem a eficiência no uso da água ${ }^{32}$. Além disso, sugerem que diferentes stakeholders podem influenciar essas

\footnotetext{
${ }^{32}$ É sugerido no documento final que as empresas contabilizem a Pegada Hídrica de toda a sua cadeia produtiva.
} 
mudanças, como os consumidores, investidores e universidades, originando um mercado que considere a questão da água.

No entanto, é preciso considerar também que neste caso, quem dita as regras são aqueles que são capazes de cumpri-las, geralmente as grandes empresas que tem acesso a financiamentos, tecnologias e recursos humanos. Isso pode gerar um efeito negativo para as pequenas empresas e pequenos produtores, quando se fala na indústria alimentícia, por exemplo. Deste modo, é preciso estar atento para que o mercado não reproduza um modelo que favoreça os já favorecidos.

Novamente, a principal solução apontada até o momento está relacionada com medidas situadas em uma modernização ecológica fraca, baseada na ecoeficiência e em mecanismos de mercado (OELS, 2005; TOKE; STRACHAN, 2006). Nesse sentido, é preciso considerar o papel do Estado como regulador e os movimentos ambientais para cooperarem, promovendo uma reflexão crítica sobre o modo de produção e consumo da sociedade, que considerem tanto o aspecto fundamental da água para manutenção de todas as formas de vida e atividades socioeconômicas, mas também sua finitude. 


\section{Capítulo 7 Por que usar a Pegada Hídrica nas Empresas? Uma proposta de sistematização dos motivos encontrados na revisão bibliográfica sistemática}

Conforme apresentado anteriormente, a avaliação da Pegada Hídrica tem sido utilizada em diversas escalas e contextos de estudos, como bacias hidrográficas, países e setores econômicos (CHAPAGAIN; TICKNER, 2012).

Neste capítulo serão apresentados os resultados obtidos por meio de uma revisão bibliográfica sistemática (RBS), realizada para compreender os motivos têm levado as empresas de diferentes setores a utilizarem a da Pegada Hídrica em seus processos produtivos.

Relembramos que a seleção dos documentos analisados ocorreu com base nos seguintes critérios de inclusão: a) documentos que utilizaram o método da Water Footprint Network b) documentos que aplicaram a Pegada Hídrica no âmbito empresarial, independente do escopo do estudo (cadeia produtiva completa ou parcial); c) estudos que tenham relação com uma empresa real.

Na busca realizada na base de dados Web of Science, foram levantados 382 artigos que continham o termo "waterfootprint" no título, resumo ou palavras-chave. Após a realização de três triagens, o número de artigos considerados para análise foi reduzido a 10 , representando $2,6 \%$ da amostragem inicial.

O resultado da revisão bibliográfica sistemática realizada na página da organização Water Footprint Network contabilizou 190 documentos, entre artigos científicos e relatórios. Do mesmo modo, o total de documentos considerados para a análise foi 13 , sendo onze relatórios e dois artigos científicos, representando 6,8\% da amostragem inicial.

Portanto, considerando as duas plataformas de busca, 23 documentos atenderam aos critérios de inclusão e foram analisados, sendo 12 artigos científicos e 11 relatórios (Tabela $1)$. 
Tabela1. Resultado da revisão bibliográfica sistemática.

\begin{tabular}{ccccc}
\hline Base de dados & $\begin{array}{c}\mathrm{N}^{\circ} \text { documentos } \\
\text { (triagem 1) }\end{array}$ & $\begin{array}{c}\mathrm{N}^{\circ} \text { documentos } \\
\text { (triagem 2) }\end{array}$ & $\begin{array}{c}\mathrm{N}^{\circ} \text { documentos } \\
\text { (triagem 3) }\end{array}$ & $\begin{array}{c}\mathbf{N}^{\circ} \text { documentos } \\
\text { analisados }\end{array}$ \\
\hline $\begin{array}{c}\text { Web of Science } \\
\begin{array}{c}\text { WaterFootprint } \\
\text { Network }\end{array}\end{array}$ & 382 & 59 & 30 & $\mathbf{1 0}$ \\
TOTAL & 190 & 27 & 18 & $\mathbf{1 3}$ \\
\hline
\end{tabular}

Os documentos resultantes dos levantamentos realizados nas duas plataformas foram publicados entre 2002 e 2014, e sua distribuição ao longo dos anos pode ser observada na Figura 8, assim como a distribuição temporal da publicação dos 23 documentos analisados nesta pesquisa.

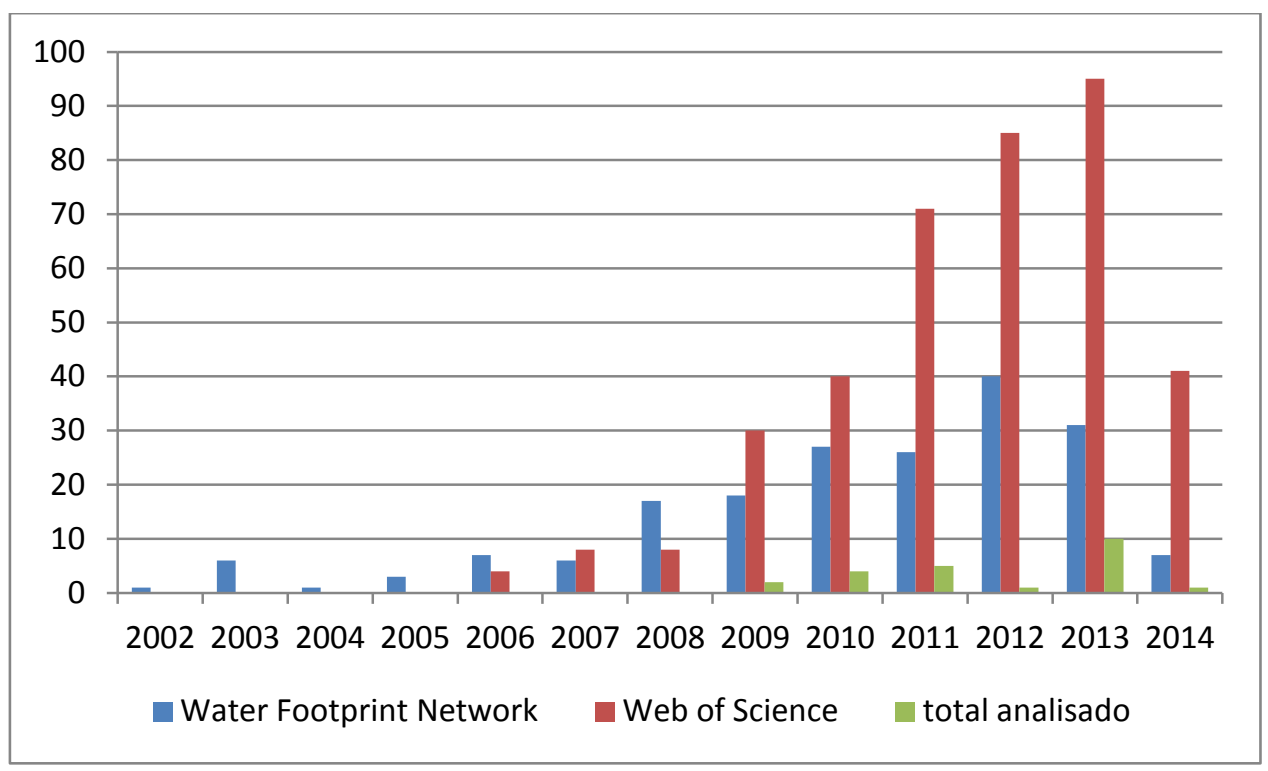

Figura 8. Distribuição do universo amostral inicial levantado nas duas plataformas (Water Footprint Network - WFN e Web of Science) e do total analisado, por ano de publicação. Elaborada pela autora.

Além de buscar nos 23 documentos os motivos que levaram à realização dos estudos de $\mathrm{PH}$, foram extraídas outras informações que permitem compreender qual pode ser o alcance da utilização da $\mathrm{PH}$ para contribuir com as empresas para abordar as questões relacionadas à água. 
Nesse sentido, em cada documento buscou-se verificar até qual fase da avaliação da PH os estudos analisados chegaram, de acordo com o manual de orientação para utilização método. O manual identifica quatro fases da avaliação da $\mathrm{PH}$, classificadas em fase 1, 2, 3 ou $4^{33}$ (HOEKSTRA et al.,2011).

Ainda, foi observado se o escopo do estudo de $\mathrm{PH}$ dos documentos analisados compreendia toda a cadeia produtiva ou somente parte dela, como por exemplo, a fase operacional (industrial) ou agrícola. Todos estes resultados estão compilados e sintetizados no Quadro 2.

Os argumentos que justificam a utilização da PH pelo setor empresarial extraídos dos documentos analisados na RBS, foram agrupados pela semelhança de seu conteúdo e classificados em quatro categorias, conforme apresentado na Figura 9. São elas: vantagens do método; riscos; tomada de decisão; e comunicação com stakeholders.

Estas categorias foram elaboradas a partir das respostas encontradas no material pesquisado $^{34}$ e se concretizam como resultado do diálogo com os referenciais teóricos anteriormente desenvolvidos.

Vantagens do Método

\section{Riscos}

\section{Tomada de decisão}

Comunicação

com

Stakeholders

Figura 9. Classificação das informações extraídas dos documentos analisados sobre a utilização da PH por empresas. Elaborado pela autora.

A frequência com que cada categoria dos argumentos motivadores aparece nos 23 documentos analisados pode ser observada na Figura 10. No Quadro 3 (Apêndice) além dos argumentos que explicam a utilização da PH, estão organizadas outras informações, como por

\footnotetext{
${ }^{33}$ Fase 1 = definição de escopo e objetivos; fase 2 = contabilização da PH; fase 3 = avaliação da sustentabilidade da PH; e fase 4 = formulação de respostas.

${ }^{34}$ Ver Figura 5, na Seção II.
} 
exemplo, o setor econômico dos estudos que compõem a revisão bibliográfica sistemática realizada e o tipo de cada documento.

Na leitura completa dos 23 documentos, foi observado que depois da realização do estudo de Pegada Hídrica, no final de cada documento, os autores voltam a mencionar os motivos pelo quais a PH pode ser utilizada e como sua utilização pode contribuir com as empresas para lidar com as questões relacionadas à água. Por esta razão, com o objetivo de comparar se as categorias dos argumentos motivadores identificados nos documentos se mantinham depois da realização do estudo de $\mathrm{PH}$, também foram organizadas no Quadro 2 as categorias mencionadas no final dos documentos.

Deste modo, os motivos que justificam a utilização da PH nos estudos analisados neste trabalho estão organizados em duas colunas no Quadro 2. Em uma delas estão organizadas as categorias de motivos para usar a PH "antes da realização do estudo de PH", presentes geralmente na introdução dos documentos. E na outra coluna, estão as categorias de motivos que foram identificadas “depois da realização do estudo de PH”, ou seja, nas conclusões dos documentos.

Como indicado na Figura 10, as categorias de motivos mais recorrentes, identificadas “antes da realização do estudo de PH” foram: vantagens do método (21 documentos); comunicação com stakeholders (8 documentos); riscos (5 documentos); e tomada de decisão (3 documentos).

Já as categorias mais frequentes encontradas "depois da realização do estudo de PH" foram: vantagens do método (23 documentos); tomada de decisão (10 documentos); comunicação com stakeholders (9 documentos); riscos (8 documentos). 
Quadro 2. Categorias dos motivos que justificam a utilização da Pegada Hídrica. Elaborado pela autora.

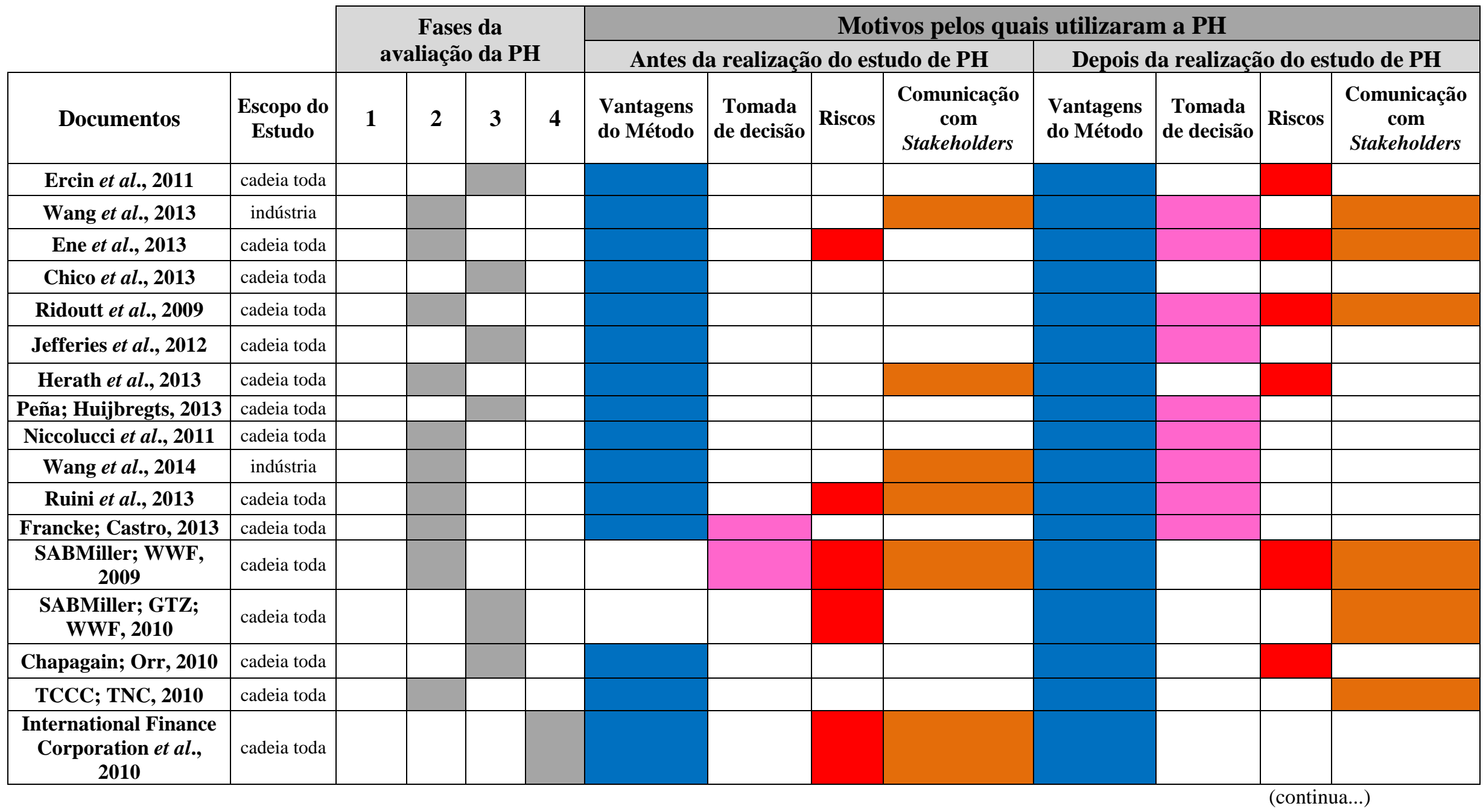


Quadro 2. Categorias dos motivos que justificam a utilização da Pegada Hídrica. Elaborado pela autora. (continuação)

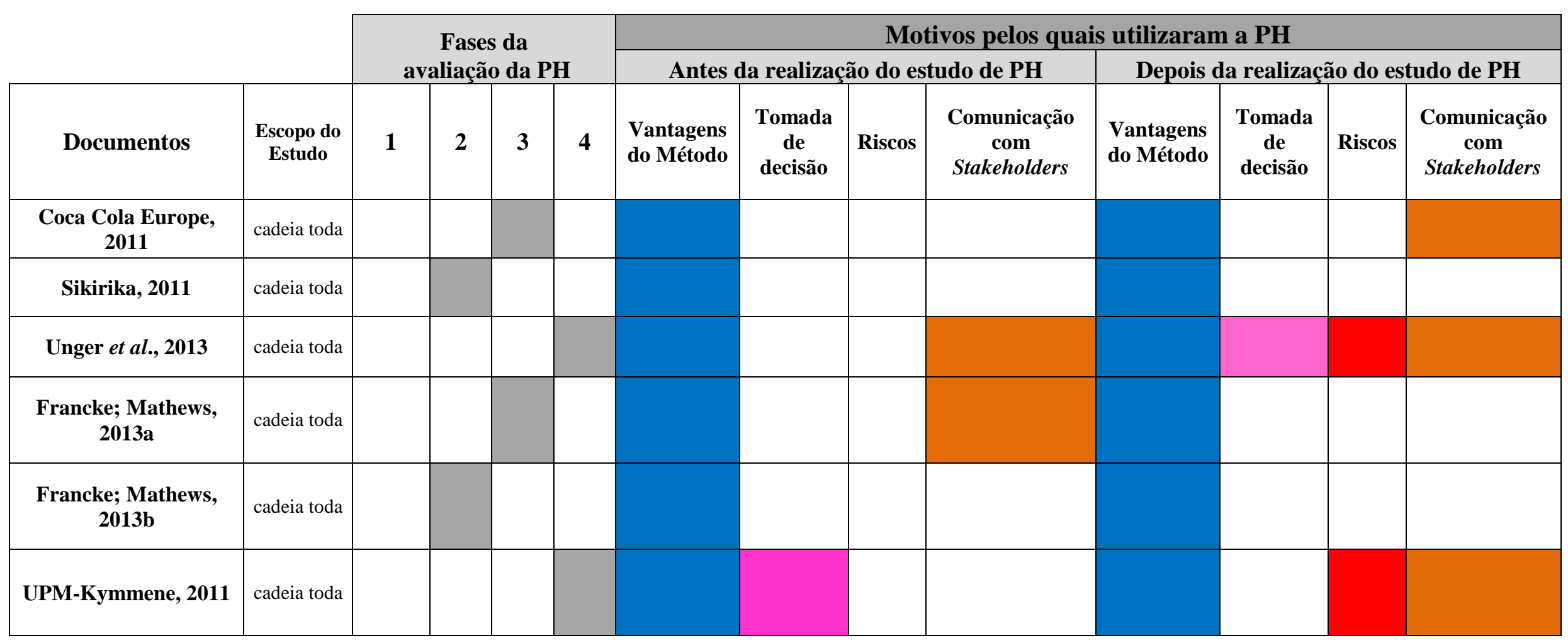




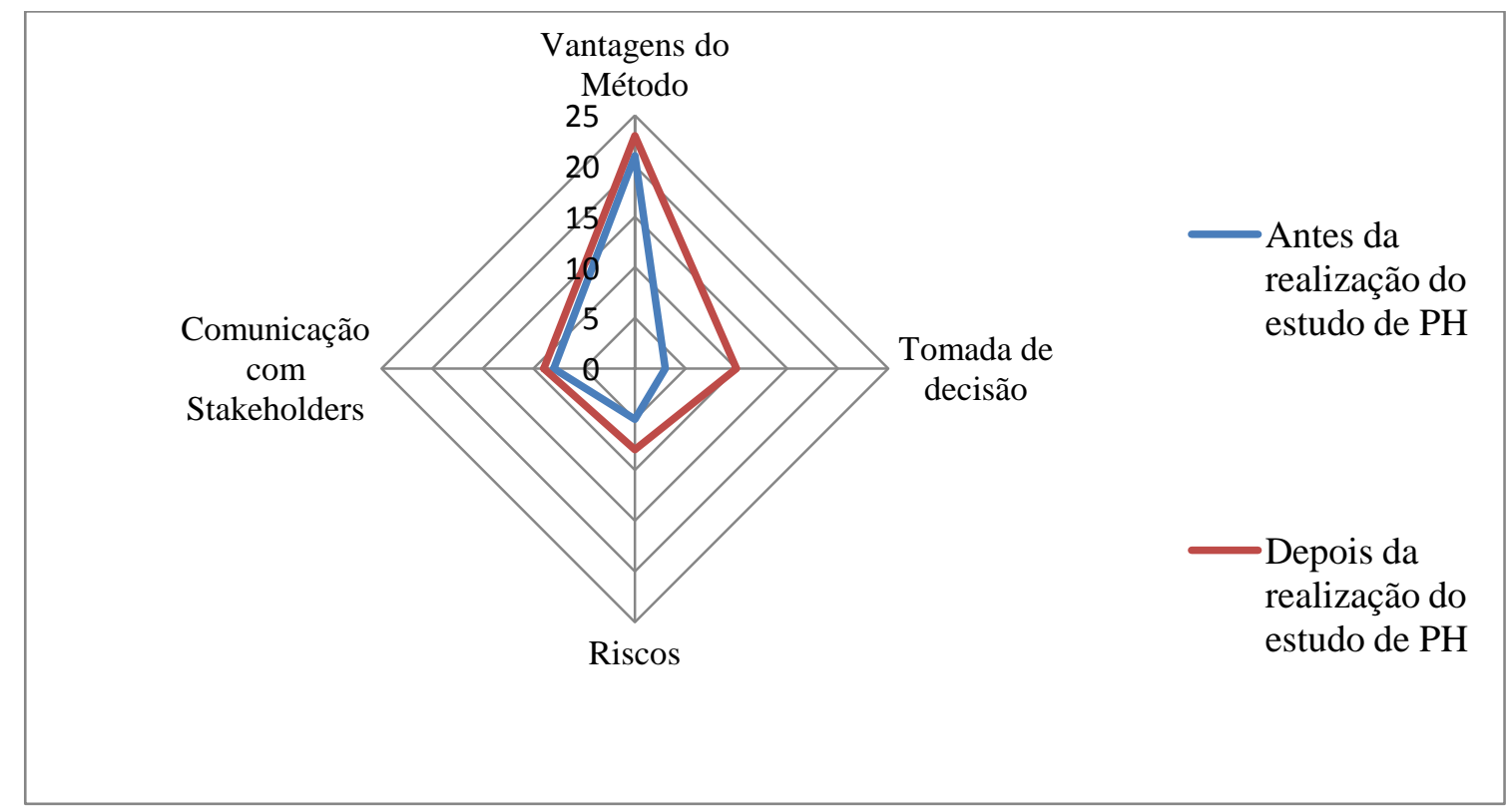

Figura 10. Número de artigos por categoria de argumento apresentado "antes da realização do estudo de PH" e "depois da realização do estudo de PH". Elaborado pela autora.

\subsection{Análise e discussão dos resultados da revisão bibliográfica sistemática}

O resultado do levantamento bibliográfico realizado inicialmente, que totalizou 572 documentos, indica o crescimento no número de publicações que abordam o tema Pegada Hídrica, principalmente a partir de 2009, conforme pode ser observado na Figura 8. Do mesmo modo, a distribuição das publicações ao longo dos anos mostra que se trata de um tema recente e que tem ganhado visibilidade, concentrando-se na sua maioria nos últimos cinco anos.

Ao mesmo tempo, quando verificamos o conjunto de documentos que atenderam aos critérios de inclusão delineados para esta pesquisa, 23 no total, é possível notar que o número de publicações é bastante reduzido, porém acompanha a tendência geral de crescimento observada para as duas bases de busca utilizadas, Web of Science e Water Footprint Network.

O número reduzido dos estudos publicados sobre a utilização da $\mathrm{PH}$ no setor empresarial considerado nesta pesquisa pode ser explicado porque os volumes que expressam a PH de um produto, por exemplo, costumam ser maiores do que aqueles contabilizados no balanço hídrico convencional que considera somente a água azul. Isto está relacionado com a característica do método de contabilização da $\mathrm{PH}$, que por ser mais abrangente, considera também a água verde e a água cinza, aumentando o valor total da PH. 
Deste modo, o fato de serem obtidos nos cálculos maiores volumes de água pode levar as empresas que utilizaram o indicador a não divulgar os seus resultados porque possuem receio de como será a recepção dos valores de $\mathrm{PH}$ pelos stakeholders externos às organizações. Nesse sentido, as empresas podem ser cobradas por consumidores, investidores, clientes e governos, por exemplo, pelos impactos negativos de suas atividades sobre a água, o que pode causar danos à imagem e reputação e até prejuízos financeiros.

É interessante observar que os estudos de $\mathrm{PH}$ relacionados às empresas que foram analisados são publicados depois de 2008, ano da criação da rede Water Footprint Network (WFN), como consta na linha do tempo apresentada no capítulo anterior. Assim, o fato de o método ter sido recentemente disponível para as empresas pode ajudar a explicar a escassez de estudos de $\mathrm{PH}$ de empresas.

O fato de a WFN publicar os trabalhos na sua página na Internet mostra o papel da rede como difusora do conceito $\mathrm{PH}$ e de certa forma como facilitadora da comunicação entre empresas e academia (WFN, 2014).

Nesse sentido, os resultados mostram que apesar de os estudos de PH ainda serem escassos no ambiente corporativo, a utilização do método pode ser um canal de aproximação das universidades e centros de pesquisa para promover a colaboração com as empresas no diagnóstico sobre o uso da água de forma mais racional e eficiente nos processos produtivos. Nesse sentido, é possível observar que alguns estudos de $\mathrm{PH}$ foram realizados por meio de parcerias entre diferentes instituições, como por exemplo, universidade e empresas (RUINI $e t$ al., 2013; WANG et al., 2013), empresas e ONGs (SABMILLER; WWF, 2009; SABMILLER; GTZ; WWF, 2010; CHAPAGAIN; ORR, 2010; THE COCA-COLA COMPANY; TNC, 2010) e outros arranjos (INTERNATIONAL FINANCE CORPORATION et al., 2010; SIKIRICA, 2011; FRANCKE; CASTRO, 2013).

Estes novos arranjos representam um exemplo do que é discutido na modernização ecológica, isto é, a colaboração entre atores de diferentes esferas para que sejam realizados avanços para lidar com as questões relacionadas à água e sejam alcançados melhores resultados, como diminuição do consumo e da contaminação da água (MOL, 2000). Além disso, destaca-se o papel das ONGs, como TNC e WWF, trabalhando em parceria com as empresas, influenciando as estratégias corporativas para abordar a temática da água. Esta aproximação se diferencia do comportamento de confrontação adotado por parte do 
movimento ambientalista, e tem sido substituído por estratégias de colaboração e cooperação (GONÇALVES-DIAS; TEODÓSIO, 2011).

\subsection{Análise das categorias definidas na revisão bibliográfica sistemática}

Conforme descrito na seção anterior (Considerações Metodológicas) os argumentos que explicam o motivo da utilização da PH extraídos dos documentos analisados foram classificados em quatro categorias, de acordo com suas características.

Destas quatro categorias elaboradas, os motivos mais frequentes apontados nos documentos "antes da realização do estudo de $\mathrm{PH}$ " pertencem à categoria "vantagens do método", presente em 21 dos 23 documentos analisados (Figura 10). Quando consideramos esta mesma categoria, porém "depois da realização do estudo de $\mathrm{PH}$ " podemos observar que todos os documentos mencionam que as "vantagens do método" justificam sua utilização.

As respostas relacionadas à categoria "vantagens do método", de maneira geral, estão associadas à capacidade da PH colaborar no diagnóstico sobre o uso e consumo da água em toda a cadeia produtiva, oferecendo uma perspectiva mais ampla e detalhada sobre a pressão exercida a este recurso natural. Como pode ser observado no Quadro 2, 21 documentos analisados compreenderam toda a cadeia produtiva nos estudos de $\mathrm{PH}$.

Nesse sentido, alguns autores argumentam que um estudo de PH contribui na identificação tanto das fases dos processos produtivos que são mais intensivos em água e que possuem maior potencial contaminante, como também a técnica produtiva que exerce mais pressão no uso da água, e também na identificação dos ingredientes que mais contribuem para aumentar a PH (JEFFERIES et al., 2012; ENE et al., 2013; NICCOLUCCI et al., 2013; PEÑA; HUIJBREGTS, 2013).

Como exemplo, podemos citar o estudo de Ruini et al. (2013) que ao contabilizar a PH de um quilo de massa produzida pela Barilla identificaram que a fase agrícola, de cultivo do trigo, é a maior responsável pela PH. Para diminuir o consumo de água na produção de trigo, concluiu-se que a utilização de variedades de trigo que são mais resistentes ao estresse hídrico pode ser um caminho para reduzirem sua $\mathrm{PH}$.

Outros estudos além deste identificaram que a fase agrícola costuma corresponder à maior parte da Pegada Hídrica total dos produtos que possuem ingredientes de origem vegetal 
(CHICO et al., 2013; FRANCKE; CASTRO, 2013; SOJAMO; LARSON, 2012; CHAPAGAIN; ORR, 2010; THE COCA-COLA COMPANY; TNC, 2010; SABMILLER; WWF, 2009).

No caso de agricultura irrigada isso ganha mais relevância considerando a tendência de aumento da vazão de retirada de água para este fim. Segundo a Agência Nacional de Águas, no Brasil a irrigação é responsável pela maior parcela retirada de água quando comparado aos outros usos consuntivos, correspondendo a 54\% do total retirado e $72 \%$ do total consumido (ANA, 2013). Considerando o cenário global, Hoekstra e Mekonnen (2012) apontam que o setor agrícola é o maior consumidor de água.

Dentro do setor agrícola, o sistema agro alimentar é reconhecido como um dos principais setores intensivos em água. Esse quadro torna-se ainda mais complexo quando se considera toda a cadeia de produção de alimentos, desde a fase produtiva até a fase de processamento industrial (SOJAMO et al., 2012). No caso desta pesquisa, dos 23 documentos analisados, 14 fazem parte do setor de alimentos e bebidas. Deste modo observa-se por este número que as empresas do setor de bebidas e alimentos começam a internalizar a questão de serem consideradas um usuário intensivo de água.

É comum que as diferentes fases da cadeia produtiva do setor alimentício e de bebidas, mas também de outros setores, estejam localizadas em diferentes países ou regiões que possuem condições hídricas diversas. Isso aumenta a necessidade de compreender a pressão e o impacto causado sobre a água pelos setores produtivos, ao longo de toda a sua cadeia. Ao mesmo tempo aumenta a complexidade tanto para obtenção de dados e informações, como também em relação aos aspectos associados com a comunicação e o engajamento dos diferentes stakeholders responsáveis por cada fase da cadeia produtiva para abordarem as questões relacionadas à água.

Esta questão sobre a comunicação e engajamento dos diferentes stakeholders sobre a responsabilidade compartilhada no uso da água nos remete à segunda categoria mais frequentemente mencionada como motivador para a utilização da $\mathrm{PH}$ pelo setor empresarial: “comunicação com stakeholders" (Figura 10).

Do total dos documentos analisados nesta pesquisa, oito mencionam que utilizaram a PH em seus processos produtivos pela necessidade de comunicação com todos os interessados nas atividades da empresa. 
A comunicação da empresa com os seus os diferentes stakeholders pode ocorrer por diferentes razões, como por exemplo, pela demanda de seus consumidores por transparência nas informações sobre o uso e contaminação da água, conforme apontam Herath et al. (2013) e Palhares (2011). Além dos consumidores, tem sido muito ampliado o interesse de investidores, governos e ONGs por dados e informações sobre o desempenho ambiental, e neste caso, sobre o consumo de água (BIER, 2011).

Considerando ainda a questão da comunicação, um estudo de PH pode servir como um instrumento que gera cooperação entre todas as partes da cadeia produtiva para reunir os dados e informações necessários para a contabilização da PH. Nesse sentido, a PH se torna também uma ferramenta de sensibilização e engajamento dos diferentes stakeholders, promovendo assim a ideia do compartilhamento da responsabilidade sobre a diminuição do consumo da água, capaz ainda de impulsionar melhores práticas na sua cadeia produtiva (UPM-KYMMENE, 2011; THE COCA-COLA COMPANY; TNC, 2010; SABMILLER; WWF, 2009; RIDOUTT et al., 2009).

Retomando as ideias desenvolvidas na primeira seção desta tese (Capítulo 2), considera-se a interdependência entre as empresas e a sociedade, de modo que diferentes stakeholders são capazes de influenciar a tomada de decisão dentro das organizações (FREEMAN; LIEDTKA， 1991; BANERJEE，2002; FARIA; SAUERBRONN，2008; ABRAMOVAY, 2012).

Nesse sentido, a necessidade de "comunicação com stakeholders" apontada como uma das razões que levaram à utilização da $\mathrm{PH}$ pelas empresas, indica que cada vez mais as empresas são pressionadas a prestarem contas do seu desempenho socioambiental ao público externo à organização. Isso quer dizer que as empresas reconhecem que necessitam compreender a percepção que seus diferentes stakeholders possuem sobre suas atividades, contrapondo a ideia de que sua principal função é atender exclusivamente aos interesses dos acionistas (FARIA; SAUERBRONN, 2008).

Como resultado, observa-se que as empresas tentam responder a esta demanda com iniciativas proativas que ajudam a esclarecer às diferentes partes interessadas como se dá o uso da água nos processos produtivos, por exemplo, pela adoção da PH e na sua utilização para apresentar informações sobre água. Assim, esse exercício de transmitir informações pode melhorar a reputação das empresas no mercado, campo onde ocorrem, ao mesmo tempo, 
contestações e legitimação do posicionamento de cada empresa pela sociedade (HOMMEL; GODARD, 2001; ABRAMOVAY, 2012).

Se por um lado, a demanda por transparência nas informações sobre consumo de água e impactos socioambientais de uma empresa tem aumentado, por outro lado existem as questões dos riscos atrelados à água, capazes de ameaçar de diferentes formas uma empresa e ainda causar prejuízos financeiros e danos à imagem.

Assim, além da incerteza de disponibilidade hídrica quali e quantitativa para o funcionamento das operações das empresas, o aumento da pressão pelo uso da água em um cenário de alteração climática pode aumentar os riscos regulatórios, reputacionais e financeiros (HEPWORTH, 2012; MORRISON et al., 2010; ORR et al., 2009).

A problemática sobre os riscos associados à água foi apontada como a terceira categoria de motivos que justificam a utilização da $\mathrm{PH}$ pelas empresas em cinco dos 23 documentos analisados (Figura 10). Porém, ao verificar qual tipo de riscos as empresas buscam identificar quando utilizam a PH, observa-se que o risco físico, ou seja, aquele associado à disponibilidade hídrica em quantidade e qualidade para a continuação de suas atividades é o que mais ameaça as empresas.

Nesse sentido, Unger et al. (2013) argumentam que uma empresa pode se beneficiar do uso da PH ao identificar a vulnerabilidade de cada fase da cadeia produtiva em relação a situação hídrica no local das operações. A partir do diagnóstico das condições hídricas locais, realizado pela avaliação da sustentabilidade da $\mathrm{PH}^{35}$, é possível que a empresa se antecipe a possíveis situações de escassez.

Do mesmo modo, o estudo realizado pela UPM-Kymmene (2011) reconhece que a avaliação da $\mathrm{PH}$ de toda a sua cadeia permitiu avaliar riscos futuros potenciais, além de oportunidades de melhorias no processo produtivo do papel em relação à água, como aumento do reuso de água, que reduz tanto o consumo de água como o volume de efluente lançado.

A identificação de oportunidades de melhorias no uso da água nos processos produtivos está relacionada com a quarta categoria de motivos mencionada por empresas que utilizaram a PH, que diz respeito a "tomada de decisão". Significa que a PH facilita a identificação de novas possibilidades de atuação para gerir os riscos associados à água. Por

\footnotetext{
${ }^{35}$ Fase 3 do manual de Avaliação da Pegada Hídrica (HOEKSTRA et al., 2011).
} 
ser um método mais abrangente, abre o leque de possíveis respostas tanto por ações dentro das unidades operacionais como também em toda a cadeia produtiva.

O estudo realizado por SABMiller e WWF (2009) conclui que a PH é útil para uma empresa quando ajuda a melhorar a tomada de decisão, tanto em relação à gestão da água nas suas plantas, mas também na relação com fornecedores e subsidiando o seu engajamento com o setor público. Jefferies et al. (2012) consideram ainda que a utilidade da avaliação da PH está na possibilidade de formulação de respostas robustas, permitindo à empresa incorporar mecanismos de gestão da água, minimizando os impactos sobre a água de maneira ampla e integrada, como por exemplo com práticas que aumentem a eficiência no seu uso em toda a cadeia produtiva.

É importante destacar que as categorias "tomada de decisão" e "riscos" foram apontadas com mais frequência "depois da realização dos estudos de PH", nas conclusões dos documentos analisados, como pode ser observado na Figura K. Isso reforça a utilização da PH como uma ferramenta que permite interferir nas práticas de gestão da água na cadeia produtiva.

Entretanto, é possível notar que as principais respostas elaboradas pelas empresas a partir da utilização da PH ainda estão limitadas a ações técnicas e de ecoeficiência no uso da água (NICOLUCCI et al., 2011; van OEL; HOEKSTRA, 2012; FRANCKE; MATHEWS, 2013a; PEÑA; HUIJBREGTS, 2013). Isso pode ser observado mesmo naqueles estudos que foram além da contabilização da PH, chegando até a avaliação da sustentabilidade da PH (fase 3) ou na fase de elaboração de respostas (fase 4), como indicado no Quadro 2.

O estudo conduzido por International Finance Corporation et al. (2010), por exemplo, tenta entender se a empresa que comercializa alimentos está exposta a algum risco de escassez hídrica. Ao identificar que em alguns locais há o risco de escassez de água, a empresa aponta como resposta a alteração do sistema de irrigação para uma técnica mais eficiente, como gotejamento, e ao mesmo tempo mencionam buscar novas maneiras para aumentar o fornecimento de água.

Outro estudo, conduzido pela empresa de papel UPM- Kymmene (2011) não identifica riscos de escassez hídrica nas regiões onde capta água, porém aponta que uma forma potencial 
para reduzir a PH azul da fase industrial seria com aumento de reutilização e perdas por evaporação onde existe "uma clara necessidade regulatória, ambiental ou econômica"36.

Por outro lado, neste mesmo estudo da UPM é mencionado que a empresa envia questionários para seus fornecedores de celulose e de produtos químicos para obtenção de informações sobre o uso da água. Aponta que um passo futuro no sentido de engajar toda a cadeia produtiva poderia ser a criação de diálogos com os seus fornecedores pela criação de medidas de redução da PH através da elaboração de metas e compartilhamento de melhores práticas (UPM-KYMMENE, 2011).

É possível observar, portanto, que mesmo que a avaliação da sustentabilidade da $\mathrm{PH}$ seja realizada com mais frequência (fase 3), o que permite que as empresas compreendam melhor qual é o impacto de suas atividades na bacia hidrográfica onde estão localizadas, ainda é pouco comum que as empresas se mobilizem para propor soluções coletivas para enfrentar as questões relacionadas à água.

Como apontado por Hoekstra (2014), o setor empresarial precisa atuar não apenas na gestão dos riscos, mas principalmente na gestão responsável da água ${ }^{37}$, que incluí a avaliação da sustentabilidade do uso da água em todas as fases de um processo produtivo, diminuição do seu consumo e poluição, comunicação de maneira transparente todas as informações e ainda atuar coletivamente, em parceria com diferentes stakeholders nas bacias onde cada fase do processo está instalada.

Os resultados da revisão bibliográfica sistemática indicam que a principal contribuição da utilização da PH no ambiente corporativo está no potencial para aprimorar o diagnóstico do consumo de água nos diferentes processos produtivos .

E é a partir de um diagnóstico que é possível perceber, avaliar e comunicar os riscos para os diferentes stakeholders e assim tomar decisões que visem minimizar os impactos socioambientais negativos e adotar medidas de mitigação, antes de serem cobradas por consumidores, clientes ou órgãos reguladores, por exemplo. Nesse sentido, os motivos apontados para a utilização da PH nos documentos analisados sinalizam que o método tem potencial para contribuir em todo este processo, do diagnóstico à tomada de decisão.

\footnotetext{
${ }^{36}$ Tradução nossa (UPM- Kymmene, 2011, p.19)

${ }^{37}$ Do inglês water stewardship
} 
A partir das categorias motivadoras encontradas nos documentos analisados, o diálogo entre as ideias mobilizadas nos marcos teóricos utilizados nesta tese se concretizam ao mesmo tempo em que se complementam.

Nesse sentido, a PH pode ser um elemento articulador para engajar diferentes setores e também subsidiar mudanças das práticas em relação ao uso da água, como sugere as ideias da teoria da modernização ecológica (MOL, 2010). Ainda, pode fortalecer a comunicação entre os diferentes stakeholders e colaborar com a transparência de informações e prestação de contas sobre o desempenho das empresas em relação à água, como indica a teoria dos stakeholders (FREEMAN; LIEDTKA, 1991). E por fim, por também contribuir para a identificação dos riscos associados à água, a PH permite que as empresas se antecipem às contestações feitas pelo público externo à organização, adotando medidas proativas que podem evitar danos à sua imagem e reputação, como apontam Hommel e Godard (2001). Isso tudo dentro da perspectiva de que as empresas são agentes pertencentes à sociedade e que por esta razão influenciam e são influenciados, em um constante sistema de relações sociais (GRANOVETTER, 1985; SMELSER; SWELDEBERG, 2005).

Contudo, o principal desafio que se coloca está mais relacionado com a aplicação da PH pelas empresas para lidar com a complexidade que envolve a temática da água do que propriamente com o método.

$\mathrm{O}$ conceito de $\mathrm{PH}$ foi formulado considerando que a água é um recurso natural finito e que, portanto, precisa ser alocado de modo eficiente. No entanto os sistemas produtivos e a economia global continuam funcionando como se os recursos naturais fossem infinitos ou perfeitamente substituíveis. Nesse sentido, é preciso considerar que a aplicação da PH pelas empresas ainda é realizada dentro da lógica do modus operandi econômico pautada pelo aumento dos padrões de produção e consumo (SOUZA LEAO et al., 2014).

Como argumenta Carolan (2004), ações de ecoeficiência no uso dos recursos naturais não devem ser confundidas com sustentabilidade, pois apesar de ser um passo na direção certa, não necessariamente representam em si uma redução no volume de consumo de água, por exemplo.

Para Hoekstra e Wiedmann (2014) apenas a melhoria de tecnologias e o aumento da ecoeficiência no uso da água não será suficiente para alcançar a sustentabilidade socioambiental e econômica do recurso, porque a demanda pelo recurso é crescente. Nesse 
sentido, os autores apontam que mesmo com a ampliação de medidas de ecoeficiência no uso da água pelo setor produtivo, é preciso enfrentar a questão central considerada por eles, ou seja, o atual padrão de consumo.

Assim, de acordo com Hoekstra (2014), somente o setor corporativo não será capaz de se autorregular suficientemente para conter a problemática em torno da água, como a disponibilidade hídrica para todos os usos, aumento dos custos de tratamento de água e conflitos, por exemplo. Diante disso ele argumenta que é extremamente necessário que haja regulação por parte dos governos e também acordos de cooperação internacional, para desenvolver valores máximos de $\mathrm{PH}$ para cada bacia hidrográfica.

Estas últimas duas necessidades, agregadas à ecoeficiência no uso da água, transparência e participação dos diferentes stakeholders atuando colaborativamente em uma bacia hidrográfica, seria uma aproximação à modernização ecológica forte, o que implica na ampliação do debate público e na reflexão da sociedade sobre o compartilhamento da responsabilidade pelo uso da água (CHRITSOFF, 2004).

No entanto, ainda se observa que os limites físicos e a capacidade de suporte dos ecossistemas continuam a ser negligenciados, apesar dos avanços significativos do recente e importante envolvimento do setor empresarial na temática da água. Obviamente que como todo processo, esse movimento é lento e tardará alguns anos para que seja traduzido, ou não, em resultados positivos em direção a sociedades mais equilibradas socioambientalmente.

É interessante observar que a presença da água na agenda das empresas é reflexo dos novos arranjos institucionais que têm sido organizados principalmente na última década. Nestes espaços a discussão tem sido fomentada e ampliada, e nota-se cada vez mais frequente a participação do setor empresarial. Como considera Abramovay (2006; 2012), isso significa que as empresas privadas não são "caixas-pretas", totalmente imunes ao que pensa e exige a sociedade. 


\section{Capitulo 8 - A aplicação da Avaliação da Pegada Hídrica por duas grandes empresas brasileiras}

Este capítulo tem como objetivo explorar mais profundamente a aplicação da avaliação da Pegada Hídrica por meio de estudos de caso com duas empresas brasileiras, a Natura, empresa de cosméticos, e a Fibria, empresa do setor de celulose.

Assim, ao apresentar os estudos de caso, pretende-se compreender tanto as motivações que levaram as duas empresas selecionadas a utilizarem a Pegada Hídrica para abordar suas questões em relação à água, como também esclarecer qual pode ser a contribuição da ferramenta para o setor empresarial. A intenção é verificar ainda se as razões pelas quais as empresas estudadas iniciaram seus estudos de PH corroboram com os resultados encontrados na revisão bibliográfica sistemática, apresentada no capítulo anterior.

O capítulo está organizado da seguinte maneira. Inicialmente é feita uma breve apresentação de cada empresa, com base em informações contidas nos relatórios disponíveis nas suas respectivas páginas na Internet. Em seguida as informações obtidas em cada entrevista são apresentadas, divididas em quatro grandes tópicos, a saber:
A) Gênese da Pegada Hídrica na empresa - a emergência da água na agenda corporativa
B) O estudo de Pegada Hídrica na Natura e na Fibria
C) As relações entre os diferentes stakeholders e Pegada Hídrica
D) O futuro da Pegada Hídrica

\subsection{Natura e Fibria: caracterização das empresas estudadas}

A Natura, fundada em 1969, é uma empresa brasileira de capital aberto na BM\&FBovespa desde 2004. Atualmente possui 59, 83\% das ações com o grupo controlador, 30,10\% de ações em circulação e 10,7\% com administradores e tesouraria (NATURA, 2013). 
Com sede em Cajamar, localizada na Bacia Hidrográfica do Alto Tietê ${ }^{38}$, São Paulo, a empresa tem forte presença na América Latina, com operações na Argentina, Chile, Peru, Colômbia e México.

A Natura é uma marca líder no setor de higiene, perfumaria e cosmética, considerada atualmente a maior empresa do Brasil no setor de higiene pessoal, perfumaria e cosméticos, com cerca sete mil colaboradores, cinco mil fornecedores, 32 comunidades extrativistas, 1,6 milhão de consultoras (vendedoras) e com alcance de aproximadamente de 100 milhões de consumidores (NATURA, 2013).

Seu modelo de negócio está baseado em uma rede de consultoras que realizam venda direta, o que permite compartilhar os valores da empresa, ao mesmo tempo em que as impressões das consumidoras são levadas para dentro da empresa (NATURA, 2014).

A Natura tem um histórico de inovação e engajamento nas questões socioambientais. Por exemplo, foi a primeira empresa de cosméticos a oferecer refil dos cosméticos que comercializam, iniciativa que começou em 1983. Seu funcionamento está pautado pela sustentabilidade, pelo apoio a projetos de comunidades e instituições que promovam as melhores práticas e no fortalecimento das relações humanas, entre os diversos atores interessados nas suas atividades (NATURA, 2014).

A Fibria, líder mundial na produção de celulose de eucalipto, é criada em 2009, resultado da incorporação da Aracruz pela Votorantim Celulose e Papel S.A. (VCP) e possui cerca de dezessete mil trabalhadores. Com capacidade produtiva de 5,3 milhões de toneladas anuais de celulose, a Fibria possui uma base florestal de 846.282 mil hectares ${ }^{39}$, localizada em SP, MG, RJ, ES, MS e BA, e três plantas industriais, localizadas em Jacareí (Bacia Hidrográfica do Paraíba do Sul), Aracruz (Bacia Hidrográfica do Rio Doce) e Três Lagoas (Bacia Hidrográfica do Rio Paraná), que produziram juntas, em 2013, 4,7 milhões de toneladas de celulose. Em 2012 a Fibria firmou uma parceria com a empresa canadense Ensyn para investir no segmento de combustíveis renováveis a partir de madeira e biomassa (FIBRIA, 2013).

Como a Natura, a Fibria é uma empresa de capital aberto cuja estrutura acionária é composta de 29,42\% Votorantim Industrial S.A, 30,38\% BNDES e 40,20\% em circulação

\footnotetext{
${ }^{38}$ Região que enfrenta problemas em relação à baixa disponibilidade hídrica em dois sistemas de abastecimento de água, o sistema Cantareira e o sistema Alto Tietê.

${ }^{39}$ Dos quais 288.786 mil hectares são destinados à conservação ambiental (FIBRIA, 2014).
} 
livre. Das ações de circulação livre, $29 \%$ estão na bolsa de Nova Iorque e $71 \%$ BM\&FBovespa (FIBRIA, 2014).

Mais de $90 \%$ da celulose produzida pela empresa é exportada para Europa (39\%), América do Norte (28\%), Ásia (24\%) e America Latina (9\%), principalmente para fabricação de papeis sanitários (FIBRIA, 2013).

\subsection{Estudos de Caso: a Pegada Hídrica na Natura e na Fibria}

Neste subcapítulo serão apresentadas as informações obtidas nas entrevistas com o Gerente Geral de Meio Ambiente da Fibria e com a Gerente de Científica de Tecnologias Sustentáveis da Natura. As informações foram organizadas nos mesmos tópicos nos quais foram elaboradas as questões norteadoras das entrevistas e correspondem às opiniões e informações fornecidas pelos entrevistados. No item 8.3 será realizada uma discussão na qual se resgata os resultados da revisão bibliográfica sistemática (Capítulo 7) e também os referenciais teóricos.

\section{A) A gênese da Pegada Hídrica na Natura e na Fibria}

A Natura é uma empresa que desde seu início está voltada para a questão do equilíbrio entre economia, sociedade e meio ambiente. A sustentabilidade, para a empresa, está baseada nestes três pilares, o conhecido triple bottom line.

As questões relativas à água têm sido consideradas pela Natura desde quando o complexo da Natura de Cajamar foi construído, pela presença de uma estação de tratamento de esgoto para lançar seu efluente industrial tratado e minimizar os impactos à qualidade da água do rio receptor. Além disso, sempre existiu um indicador de consumo de água dentro da planta industrial, com objetivo de reduzir o consumo por unidade produzida.

Atualmente, a Natura não identifica nenhum hotspot que ofereça algum risco físico em relação à disponibilidade de água, mas reconhece que a questão da deterioração de sua qualidade pode causar algum problema no futuro, como apontado a seguir:

\footnotetext{
“A gente não identificou ainda nenhum hotspot como outras empresas do setor de bebida ou alimentos... No Brasil não existe um problema [em relação à água] tão relevante como na Índia e outros países. Obviamente a
} 
gente entende que existe um risco muito grande, principalmente relacionado à qualidade das águas, mas isso é o que a gente vai descobrindo pelo estudo (de PH), mas não alguma coisa que atinge a gente."

Apesar disso, para a Natura, a água é uma questão estratégica, assim como os gases de efeito estufa e mudanças climáticas, sociobiodiversidade e resíduos sólidos. Estes são os grandes temas que norteiam as práticas da empresa em relação à sustentabilidade.

A demanda para que os estudos de $\mathrm{PH}$ se iniciassem surge dentro da própria empresa, pelo comitê de sustentabilidade, comitê de alta gestão da Natura. Isso ocorreu em 2007, depois que se tornaram carbono neutro, através da compensação das emissões que não podem ser evitadas no processo produtivo, por meio da compra de créditos de carbono. O Programa Carbono Neutro inclui o inventário das emissões de carbono considerando todo o ciclo de vida do produto. É a partir deste programa que a Natura passa a compreender que os impactos de suas atividades estendem-se para além de suas unidades operacionais (fábricas), e se dão tanto no início da cadeia, com a produção agrícola, como no final, pelos consumidores.

Nesse sentido, com base na Pegada de Carbono, a Natura decide iniciar um processo semelhante com a água. Assim, em 2008 iniciam-se os esforços para trabalhar com o método proposto por Hoekstra ${ }^{40}$ e no ano seguinte a Natura se associa à rede Water Footprint Network (WFN).

No início deste processo, praticamente não existiam referências para a realização do estudo de PH em âmbito corporativo, já que a primeira edição do manual seria publicada em 2009, depois da criação da rede WFN, confirmando o caráter pioneiro e antecipatório da Natura.

Para a Fibria, a sustentabilidade é entendida como uma questão estratégica. Por ser uma empresa global, que comercializa commodities para diferentes países, ao se posicionar pela vertente social e ambiental da sustentabilidade, a empresa entende que apresenta um diferencial competitivo. De acordo com o informante, o posicionamento da Fibria em relação à sustentabilidade é valorizado e estimulado pelos seus clientes, sobretudo aqueles localizados

\footnotetext{
${ }^{40}$ Manual de Avaliação da Pegada Hídrica - Hoekstra et al., 2011.
} 
na Europa, que pressionam por mais informações socioambientais da cadeia produtiva da celulose que compram.

Foi mencionado ainda que a Fibria foi incluída em 2013 no Índice Dow Jones de Sustentabilidade (Dow Jones Sustainability Index - DJSI) e no Índice de Sustentabilidade Empresarial (ISE) da BM\&FBOVESPA, fazendo com que suas ações sejam mais valorizadas no mercado, conforme explica o entrevistado:

\begin{abstract}
“A sustentabilidade é hoje um posicionamento estratégico, ambiental e social da Fibria. Fazer parte do Índice de Sustentabilidade da bolsa de Nova Iorque (Dow Jones), que é um indicador de mercado que mostra a empresas mais sustentáveis, valoriza mais as ações e remunera melhor os acionistas. Então ela é estratégica. Ela impacta o valor reconhecido da empresa pelo indicador econômico, que é o fundamental."
\end{abstract}

Dois aspectos tornam a temática da água uma dimensão importante na agenda da Fibria. De acordo com a informação obtida na entrevista, o primeiro aspecto se configura na identificação da relevância da água para a empresa por meio da elaboração da matriz de materialidade $^{41}$, com a participação de diferentes stakeholders (comunidade, academia, ONGs, poder público, fornecedores, concorrentes) durante um workshop realizado a cada dois anos. O resultado do estudo de materialidade apontou a água como um dos cinco temas relevantes para as atividades da empresa.

O segundo aspecto considerado, que tem consolidado a água como tema prioritário na produção de celulose, está relacionado com o fato de que em 2005 a Fibria (na época VCP) passa a ser signatária do pacto de produção mais limpa do PNUMA/ONU. O pacto de produção mais limpa sugere que as empresas trabalhem com o conceito de eco eficiência, que prevê que se produza mais com menos recurso.

Nesse sentido, conforme comentado pelo entrevistado, a empresa está desenvolvendo um programa de benchmarking que inclui, dentre outros indicadores, o consumo e reciclagem da água dentro do circuito industrial que fazem parte do Índice de Desempenho Ambiental (IDA) da Fibria. O IDA compõe o cálculo da remuneração variável dos funcionários em

\footnotetext{
41 A matriz de materialidade identifica as questões mais relevantes para a empresa e para a sociedade, levando em conta sua estratégia e a visão dos públicos com os quais se relaciona (FIBRIA, 2013).
} 
função do desempenho ambiental da empresa ${ }^{42}$. Deste modo, quanto mais eficientes os processos industriais, melhor será o IDA e também a remuneração dos funcionários.

De acordo com o entrevistado, a Fibria tem seu primeiro contato com o método da Pegada Hídrica através Associação Brasileira Técnica de Celulose e Papel (ABTCP). Depois disso, acompanha as discussões sobre a PH e suas aplicações e com o passar do tempo entende que seria interessante conhecer a sua PH. A ideia inicial era de entender a importância do impacto das atividades da empresa em relação à água e no entorno das plantas industriais. Sua filiação à rede WFN ocorre a partir de 2010.

Assim, como a água é um insumo fundamental para as operações da empresa, ela é abordada em estudo especial: a PH da celulose. Até então a problemática da água era abordada através do manual de melhores práticas da empresa, junto com outros temas, como por exemplo, biodiversidade e resíduos sólidos.

Apesar de reconhecer a água como um recurso fundamental para a manutenção das atividades da Fibria, a empresa não identifica que a situação hídrica dos locais onde suas plantas estão instaladas ofereça qualquer tipo de risco físico à continuação do funcionamento das fábricas, seja em relação à qualidade como à quantidade. No caso da planta de Aracruz, estrategicamente a empresa se antecipou e resolveu a questão da insuficiência hídrica com obras de infraestrutura, ao transpor água do Rio Doce, para três reservatórios usados pela empresa para fornecer água para a produção de celulose. Sobre isso, o entrevistado diz:

\footnotetext{
"Não identificamos nenhum problema em relação à água porque nossa captação, a captação do setor é muito pequena."
}

Entretanto, uma preocupação apontada pela Fibria em relação à água é o aumento do valor da cobrança pelo seu uso, principalmente na bacia hidrográfica do rio Paraíba do Sul, onde está uma de suas plantas industriais. De acordo com o entrevistado, a Agência Nacional de Águas (ANA) tem dado indícios de que haverá aumento dos valores pelas discussões que têm sido realizadas no comitê de bacia hidrográfica do rio Paraíba do Sul.

Quando questionado sobre a existência de conflitos em relação à água pelas atividades da empresa, a resposta do informante foi a mesma. Ou seja, o representante da Fibria não

\footnotetext{
${ }^{42}$ Os indicadores do IDA estão divididos em: controle da poluição, prevenção à poluição e gestão ambiental (FIBRIA, 2013).
} 
identifica que haja conflito pelo uso da água em nenhuma das bacias onde suas plantas industriais ou florestas de eucalipto estão localizadas.

\section{B) Sobre o estudo de Pegada Hídrica na Natura e na Fibria}

Segundo contou a entrevistada, a Natura iniciou a abordagem sobre água dentro da empresa utilizando a avaliação da Pegada Hídrica porque necessitava de um método que permitisse obter uma visão mais ampla e mais completa do uso da água em toda a sua cadeia produtiva. A ideia se origina, portanto, a partir da Pegada de Carbono e também se inspira na ferramenta de avaliação de ciclo de vida (ACV).

Naquele momento, os dois métodos disponíveis para abordar as questões hídricas eram a $\mathrm{PH}$ e a $\mathrm{ACV}$. Porém a abordagem de $\mathrm{ACV}$ em relação à água era insuficiente para atender os objetivos da Natura. Além disso, na abordagem ACV é muito comum obter os valores usados no método a partir de bancos de dados internacionais, que costumam ser pouco precisos. Desta forma, os responsáveis pelo projeto na Natura entenderam que o método disponível com maior repercussão no momento e mais adequado para contabilizar o consumo de água de um produto ou de uma empresa era aquele proposto pela WFN, a Pegada Hídrica. Isso porque o método considera também a água de chuva e a poluição resultante tanto da cadeia produtiva e do uso dos produtos, permitindo uma análise completa e com embasamento científico.

Conforme explicado pela entrevistada, inicialmente o objetivo da Natura era de realizar um estudo com enfoque no produto, uma vez que grande parte dos seus produtos é utilizada durante o banho ${ }^{43}$. Por esta razão, os consumidores costumam questionar com a empresa o impacto do uso dos óleos de banho na qualidade da água, com base nas informações que são divulgadas em relação ao descarte de óleo de cozinha na rede coletora de esgoto doméstica, que causa entupimento das tubulações e também efeitos negativos para a biota aquática, se o lançamento ocorrer direto no corpo d’água, sem tratamento.

\footnotetext{
${ }^{43}$ São chamados produtos rinsáveis.
} 
Diante disso, para o estudo piloto, realizado em 2009 em parceria com uma consultora contratada, foram selecionados dois produtos icônicos da Natura: o perfume Kaiak e o óleo trifásico de maracujá, este último rinsável. O estudo teve como escopo a contabilização da PH azul, verde e cinza da cadeia produtiva completa dos dois produtos, considerando seus ingredientes até o uso pelo consumidor.

A entrevistada considera este estudo piloto importante, pois permitiu indicar em quais fases do processo produtivo e uso dos produtos há o maior consumo de água. Por exemplo, foi possível observar que a fase agrícola resulta em uma $\mathrm{PH}$ verde grande e que a fase do consumo do óleo trifásico tem uma PH cinza bastante relevante, que é agravada nas regiões onde não há coleta e tratamento de efluente domésticos. Além disso, a partir dos resultados do estudo, surgiram novas perguntas que os envolvidos no projeto se interessaram por responder, como por exemplo, se havia diferença do resultado de PH cinza entre usar um sabonete em São Paulo e Manaus.

Deste modo, de acordo com a entrevistada, ao apresentar estes primeiros resultados para o comitê de sustentabilidade, na época, a devolutiva foi tão positiva que foi recomendado que o estudo se estendesse para contabilizar a PH da Natura como um todo, não somente de um produto.

Assim, o segundo estudo, muito mais completo e complexo, teve como escopo o cálculo da PH da Natura. Ou seja, de todas as suas atividades e produtos e de todas as operações, inclusive as internacionais. Para este estudo, o objetivo era obter um maior refinamento dos dados para permitir uma compreensão mais próxima da realidade. Com auxílio de uma consultoria, foi mapeado o percentual de coleta e tratamento de esgoto em cada estado do país, para que fosse possível compreender, por meio da PH cinza, o impacto do uso do mesmo produto rinsável em locais diferentes.

Os resultados das PHs deste segundo estudo foram contextualizados e descobriu-se que, apesar da relevância numérica da PH verde dos vegetais utilizados na cadeia produtiva, seu cultivo não representa um impacto negativo à água, pois não há irrigação e estão localizados em regiões que não enfrentam estresse hídrico. Nesse sentido, a Natura entende que, a partir destes resultados, a sua PH verde deve ser monitorada, mas não a identifica como um hotspot que mereça alguma intervenção estratégica por parte da empresa. Consideram ainda que neste aspecto, a PH verde não é um indicador relevante para a gestão, pois permite 
pouca possibilidade de atuação, como a mudança dos locais de cultivo, o que descartam absolutamente.

Além disso, os resultados deste segundo estudo foram muito importantes para reforçar como o uso dos produtos impactam a qualidade da água e como isso se dá nos estados brasileiros por meio da PH cinza, que indica a quantidade de água necessária para diluir contaminação por determinado poluente até os limites permitidos pela legislação local.

Entretanto, apesar oferecer uma noção sobre a amplitude do impacto à qualidade da água, para a Natura, a PH cinza não é um indicador adequado para a tomada de decisão, pois se trata de um volume teórico. A Natura busca um indicador que mostre o impacto de maneira mais precisa. Isso implica que o indicador considere outros aspectos, como a ecotoxicidade e biodegradabilidade de cada ingrediente da fórmula, para que seja possível, além de comparar um produto com outro, fazer a gestão do processo produtivo pela perspectiva do impacto na qualidade da água. Além disso, informações mais precisas servem muito mais aos consumidores do que o volume teórico resultado do cálculo da PH cinza.

A necessidade de aprimorar e ajustar o indicador de água cinza fez com que fosse desenvolvido o terceiro estudo de PH realizado na Natura, decisão endossada pelo comitê estratégico.

Deste modo, o terceiro estudo, realizado com o apoio de duas consultorias, teve como objetivo definir um método que seja capaz de indicar o impacto do processo produtivo e uso dos produtos Natura em relação à qualidade de água e que possa ser utilizado dentro da empresa, na elaboração de estratégias.

Para isso, diferentes métodos foram pesquisados e cinco foram testados em dois outros produtos: um creme facial e outro óleo de banho; e os resultados encontrados divergiam totalmente, porque cada método possui endpoints diferentes. Apesar disso, segundo a Natura, o interessante do trabalho é que cada método mostra uma vertente de impacto, indicando uma relação entre o produto e o meio ambiente.

Até 26 de novembro de 2013 (data da entrevista), a Natura ainda não havia definido o método usado para aferir o impacto de seus produtos à qualidade da água para então publicamente oficializar seus compromissos. A ideia é que o indicador fosse parecido à $\mathrm{PH}$ cinza, mas que compreendesse os aspectos relacionados com a ecotoxicidade e 
biodegradabilidade dos produtos, podendo assim ser usado para a tomada de decisão pelo departamento que desenvolve os produtos.

Na Fibria, os estudos sobre Pegada Hídrica surgiram por iniciativa do gerente geral de meio ambiente da empresa ${ }^{44}$, que apresentou para a diretoria o método e a proposta de realizar o estudo da PH da celulose.

Segundo o informante, apesar de a Fibria exportar mais de $90 \%$ da celulose produzida, não houve exigência direta de nenhum de seus clientes para que estudos fossem iniciados. Entretanto, como apresentado anteriormente, alguns de seus clientes, principalmente aqueles localizados na Europa, se preocupam com os impactos socioambientais causados pela cadeia produtiva da celulose.

A escolha de utilizar o indicador PH para abordar a questão da água na empresa se deu porque considerou-se que naquele momento não havia nenhum outro método tão estruturado, que permitisse um enfoque mais amplo sobre o consumo de água na cadeia produtiva. $\mathrm{O}$ fato do método da WFN classificar a água em verde, azul e cinza traz um componente inovador que não é considerado nos métodos de contabilização convencionais, que consideram somente a água azul.

O primeiro estudo desenvolvido na Fibria teve como objetivo compreender melhor o método de cálculo, a partir da contabilização da Pegada Hídrica verde, azul e cinza da cadeia produtiva da celulose nas suas três plantas, tendo 2010 como ano-base. O estudo foi executado pela equipe de pesquisadores do Centro de Estudos de Governança Socioambiental do Instituto de Energia e Ambiente da Universidade de São Paulo (GovAmb/IEE/USP), coordenado pelo Prof. Dr. Pedro R. Jacobi, através da Fundação Universidade de São Paulo (FUSP).

A opção da Fibria por ter a academia como parceira neste projeto deu-se porque desejava atribuir um caráter científico ao trabalho, além de considerar que a reputação da universidade garantiria mais respaldo e reconhecimento ao estudo, como foi explicado:

\footnotetext{
“A escolha de trabalhar em parceria com a universidade ao invés de uma consultoria ambiental deu-se primeiro porque a academia tem a reputação de ser academia, principalmente a USP. Depois, por dar uma conotação científica pro trabalho, para validar isso. E depois para propiciar, por
}

\footnotetext{
${ }^{44}$ Mesma pessoa que concedeu a entrevista para esta pesquisa.
} 
exemplo, bolsas de estudos, cooperação entre pessoas. Então sempre a academia é interessante neste aspecto. E por último é a organização, a instituição por trás.”

Como explicado pelo entrevistado, os resultados obtidos no estudo permitiram identificar em quais etapas da cadeia produtiva da celulose há maior consumo de água, além de identificar qual o componente da PH total é o mais relevante, destacando-se o componente verde da silvicultura de eucalipto e a poluição gerada no processo produtivo, representado pela PH cinza.

Diante destes primeiros resultados, houve interesse em continuar os estudos por meio de uma análise de sensibilidade dos valores de PH por unidade industrial, de modo que fosse possível apontar intervenções mais eficientes no processo produtivo da celulose de modo que a PH seja reduzida.

Uma vez que a silvicultura de eucalipto é responsável pela PH verde da produção de celulose da Fibria, na continuação dos estudos o método foi adaptado para que a demanda de água da vegetação natural onde estão localizadas as florestas de eucalipto fosse calculada e comparada com a demanda do eucalipto ${ }^{45}$. Assim, esse desdobramento teve como objetivo contextualizar o papel do cultivo do eucalipto na dinâmica hidrológica das bacias hidrográficas onde estão inseridas.

Segundo o entrevistado, este estudo sobre a demanda de água verde para os biomas e floresta de eucalipto permitiu que a empresa começasse a refletir sobre a possibilidade de realizar um próximo estudo que abordasse a provisão de serviços ecossistêmicos associados ao maciço de eucalipto mantido pela empresa.

Quando perguntado se existe intenção de realizar a avaliação da sustentabilidade da PH da celulose, o entrevistado argumentou que a avaliação da sustentabilidade da PH é muito relevante, mas esbarra na falta de dados disponíveis sobre a bacia hidrográfica o que implica na necessidade de medições in situ, elevando o custo do trabalho. Nesse sentido, ele questionou também a relação entre o custo para a Fibria desenvolver o trabalho de avaliação da sustentabilidade da PH e o benefício coletivo resultado de um estudo como este.

\footnotetext{
${ }^{45}$ Foi calculada a demanda de água para a Mata Atlântica (onde estão localizadas as unidades de Aracruz e Jacareí) e Cerrado (onde está localizada a unidade de Três Lagoas), para comparar com as florestas de eucalipto.
} 
Apesar de nenhuma decisão ter sido tomada a partir dos estudos de PH realizados, em termos de gestão interna da água na Fibria, o entrevistado considera que as expectativas em relação aos estudos de $\mathrm{PH}$ da celulose foram atendidas, pois o objetivo era compreender a aplicação do método para poderem futuramente desenhar uma estratégia na empresa em relação à água, já que o tema faz parte da matriz de materialidade da empresa.

\section{C) A relação entre os diferentes stakeholders e Pegada Hídrica}

Os estudos de aplicação do método Pegada Hídrica, realizados pela Natura, permitiram a compreensão da complexidade do método e ainda uma nova maneira de perceber a água, para além da dimensão industrial.

Apesar da comunicação com os diversos stakeholders ocorrer por canais diferentes, a empresa se preocupou em divulgar os seus esforços ao abordar a questão da água a partir da experiência com a PH, segundo a entrevistada. Assim, os seus fornecedores, por exemplo, ficaram sabendo dos projetos por estarem em contato frequente com a sede, pois são avaliados rotineiramente pela Natura. Por esta razão, já têm proximidade com os indicadores ambientais e as iniciativas da Natura que enfatizam práticas sustentáveis. Internamente, os funcionários tomaram conhecimento dos projetos sobre PH pelo setor de comunicação, além de terem sido oferecidos treinamentos.

No entanto, o principal meio de divulgação das ações da Natura em relação à PH e outros temas é o relatório anual de sustentabilidade, disponível na sua página na Internet. Entretanto, como a Natura possui um departamento de pesquisa e desenvolvimento, é muito comum que os estudos sejam publicados em congressos e periódicos científicos ${ }^{46}$. Assim, a empresa tem divulgado seus resultados dos estudos sobre PH para um público técnico e científico.

De acordo com a entrevistada, a Natura entende que a PH pode ser importante para evitar a contestação por parte dos consumidores e ampliar a conscientização. Inclusive,

\footnotetext{
${ }^{46}$ A Natura expôs seus resultados em 2011 no workshop "A Pegada Hídrica e sua aplicabilidade no setor público e privado: experiências nacionais e internacionais" e no congresso LCA XIII, em 2013. Além disso, Ines Francke, com outros autores, publicou em 2013 um artigo na revista internacional Water Resources and Industry e apresentou um estudo de caso no relatório da UNESCO-IHE "Solving the water crisis: common action toward a sustainable Water Footprint” publicado em 2012.
} 
considera que a PH trouxe uma grande contribuição para o setor corporativo que antes não havia, melhorando a compreensão da relação entre as atividades da empresa e a disponibilidade e poluição hídrica, para além da unidade industrial. A PH conseguiu trazer as preocupações e as dimensões dos impactos causados à água, tema recorrente no âmbito científico, para dentro das empresas, como apontado por ela:

“A PH é muito interessante, pois trouxe à tona a discussão da água como
um impacto, como um grande tema, que ainda estava perdido, disperso.
Para os cientistas era claro, mas para o mundo corporativo foi a PH que
trouxe isso à tona."

Entretanto, ainda considera prematura a comunicação dos impactos de suas atividades na produção e durante o uso dos produtos aos seus consumidores, apesar de ser favorável à transparência de informações ambientais relacionadas aos seus produtos. Primeiramente, porque entende que a divulgação do valor de $\mathrm{PH}$ pode confundir mais do que informar, caso a pessoa não entenda o significado daquele valor, ou como se chegou naquele valor. Em segundo lugar, porque a Natura tem trabalhado para desenvolver um indicador que seja capaz, ao mesmo tempo, de ser usado internamente, para a tomada de decisão no desenvolvimento de produtos ecologicamente menos impactantes à água, e também como informação para seu consumidor.

Deste modo, a intenção da Natura é desenvolver um indicador para a água que tenha sinergia com os outros indicadores que já utiliza, como por exemplo, o carbono, e que permita, portanto, monitorar os seus números ao refazer os cálculos periodicamente e estabelecer metas de redução de impacto.

Ao contrário da Natura, que já divulgou seus resultados de PH em eventos científicos, o posicionamento estratégico da Fibria atualmente é por não divulgar o valor total da $\mathrm{PH}$ da celulose $^{47}$. Nesse sentido, a questão da comunicação sobre PH sempre foi tomada com muita cautela e preocupação pela empresa e por esta razão os resultados tem sido apresentados em termos percentuais de cada componente da PH total da celulose (verde, azul e cinza).

Deste modo, o principal veículo que menciona a utilização da $\mathrm{PH}$ pela Fibria é o relatório anual de sustentabilidade, disponível na sua página na Internet, que alcança

\footnotetext{
${ }^{47} \mathrm{~m}^{3}$ de água/tonelada de celulose.
} 
diferentes públicos ${ }^{48}$. Além deste canal de comunicação, a empresa organiza fóruns anuais para seus clientes do mundo. Internamente, os estudos sobre PH foram apresentados nas reuniões mensais que ocorrem em cada uma das três fábricas. Em ambos os casos a reação dos participantes foi positiva em relação à iniciativa da empresa.

Sobre a aplicação do método, o entrevistado entende que estes primeiros estudos foram importantes para que a empresa pudesse obter mais conhecimento de si mesma e de suas atividades. Porém, assim como a representante da Natura, ele acredita que os valores totais de sua PH poderiam ser mal interpretados por pessoas que não conhecem o método de contabilização.

Deste modo, a PH deverá ser utilizada pela Fibria como uma ferramenta interna de gestão da água, evitando assim, desgastes que poderiam prejudicar sua imagem perante a sociedade como aconteceu com a UPM Paper, empresa finlandesa de papel, que foi bastante questionada ao divulgar seus valores totais de $\mathrm{PH}$, segundo explicado pelo entrevistado:

"Como nenhuma empresa do setor de celulose realizou um estudo de PH,
divulgar o resultado pode dar confusão porque os valores encontrados são
mais altos, já que se fala em consumo de água e não captação. A UPM
divulgou e voltou atrás rapidinho porque foi bastante questionada pela
mídia, pela sociedade e ONG. Nesse caso, a estratégia de comunicação
dos resultados de PH não foi pensada estrategicamente."

Sob este aspecto, sua estratégia é de ir aos poucos introduzindo o tema nos fóruns de discussão que já participa, como por exemplo, na ABTCP e WBCSD, pois entende que a abordagem da PH ainda é recente no mundo corporativo e é necessário tempo e maturidade para que mudanças sejam possíveis de se perceber.

Em relação ao uso da ferramenta para comunicar o comprometimento da empresa com a minimização ou mitigação de impactos à água e evitar assim algum tipo de contestação social, o representante da Fibria acredita que a PH tem pouco a contribuir no seu caso, já que a empresa é uma vendedora de commodities. Sob este aspecto, segundo ele, a PH pode contribuir muito mais para empresas que possuem ou ao mesmo tempo são marcas, que estão

\footnotetext{
${ }^{48}$ Nos relatórios de sustentabilidade a empresa menciona que utiliza a PH para abordar a questão da água internamente. Não há resultados dos estudos de PH nos relatórios.
} 
mais expostas a um mercado mais diverso e com públicos diferentes, capazes de pressionar por certos posicionamentos das empresas.

\section{D) O futuro da Pegada Hídrica na Natura e Fibria}

Para a Natura, a Pegada Hídrica é um método muito útil, pois permite uma boa aproximação com a temática da água e sua relação com uma atividade industrial. Além disso, é fácil de comunicá-la e funciona muito bem como uma ferramenta para conscientização ambiental.

Assim, a entrevistada considera que o mérito da $\mathrm{PH}$, além do pioneirismo, é que possibilidade de dar visibilidade e maior compreensão aos impactos em relação à água. Explica ainda que o setor corporativo precisa de indicadores que consigam ao mesmo tempo retratar a complexidade das informações de uma maneira inteligível e que essa informação tenha significado para quem a recebe.

Entretanto, ela acredita que para um melhor aproveitamento do método dentro da Natura, a PH deveria ser mais discutida entre as empresas, através de estudos de casos, que permitam uma avaliação com mais profundidade. Menciona que no início, durante as reuniões da WFN isso era mais frequente e que havia mais proximidade entre as empresas membro da rede. Porém, ultimamente os espaços de discussão e colaboração foram reduzidos afastando os participantes da rede e dificultando a cooperação, que pode contribuir para melhor enfrentar os desafios em relação à água pelo setor empresarial.

Conforme apontado na entrevista, os estudos de $\mathrm{PH}$ conduzidos pela Natura permitiram que os envolvidos tivessem uma visão crítica sobre o método, principalmente sobre a PH cinza, que não foi capaz de se revelar como um indicador que pudesse ser adotado na Natura para a tomada de decisão a respeito do desenvolvimento de produtos. Isso acontece porque a PH cinza considera um fator de diluição teórico, que não inclui aspectos considerados importantes para a Natura como a persistência, a ecotoxicidade ou biodegradabilidade de seus ingredientes quando são utilizados pelos seus consumidores. 
Portanto, se por um lado, a PH cinza fornece informações que raramente são consideradas, como é o caso da contaminação da água pelo consumidor ao usar os produtos, por outro, não permite que a empresa faça as devidas alterações nas fórmulas, de modo que os impactos negativos sejam realmente minimizados, conclui a entrevistada. Por esta razão, a PH cinza como consta no manual de avaliação da $\mathrm{PH}$, não é adequado para as atividades e interesses da Natura.

Apesar disso, dentro da Natura tem sido realizado um esforço para compreender todos os resultados obtidos nos estudos realizados e desenvolver um indicador que possua rigor metodológico e ao mesmo tempo se ajuste aos interesses da empresa e sintetize os impactos que desejam aferir, para que então a estratégia corporativa da empresa em relação à água seja definida.

Para a representante da Natura, o setor corporativo tem muito a contribuir para enfrentar os desafios em relação à água, por exemplo, através da publicização de suas experiências inovadoras e colaborando com a conscientização dos stakeholders, com destaque aos consumidores. Acredita ainda que pode atuar conjuntamente com o setor público e com outros diferentes stakeholders, introduzindo temas na agenda ambiental e enfrentando os problemas identificados.

Reconhece assim que a responsabilidade pelo uso da água deve ser compartilhada entre as empresas, governos e consumidores, e que atuar em parceria pode gerar melhores resultados do que o contrário.

Nesse sentido, aponta que a falta de coleta e tratamento de esgoto em diversos municípios brasileiros aumenta os impactos negativos causados à qualidade da água pelo uso dos seus produtos rinsáveis. O mesmo passa com a falta de coleta seletiva de resíduos sólidos e reciclagem do material usado como embalagens de seus produtos.

Com base nisso a entrevistada da Natura conclui que a atuação da empresa é limitada para solucionar os diferentes desafios ambientais atuais, como explica:

\footnotetext{
"Mesmo que os produtos da Natura sejam desenvolvidos para causar o menor impacto à qualidade da água ou que suas embalagens sejam $100 \%$ recicláveis, se não houver coleta e tratamento de efluentes domésticos ou coleta seletiva, como é o caso em grande parte do Brasil, as medidas tomadas pela empresa têm pouco efeito. Nesse caso, tanto o poder público
} 
como os consumidores também precisam assumir suas responsabilidades diante de tais questões."

O representante da Fibria acredita que a PH é um bom instrumento de conhecimento interno para uma empresa, pois permite uma visão detalhada do consumo de água em todo o processo produtivo. Os estudos realizados na Fibria permitiram perceber que não há total controle e monitoramento dos dados sobre água em algumas fases do processo produtivo nas suas unidades industriais. Nesse sentido considera que o estudo sobre a $\mathrm{PH}$ da celulose gerou aprendizado principalmente para a equipe envolvida no projeto.

Considera também que os resultados possibilitam que estratégias de atuação podem ser formuladas em relação à água, como por exemplo, reduzir a $\mathrm{PH}$ cinza melhorando a eficiência do tratamento de efluentes da empresa. Diferente da opinião da informante da Natura, o entrevistado entende que na Fibria o indicador de PH cinza pode ser utilizado, apesar de ser um valor teórico. Além disso, considera que como a PH é um método recente, é natural que haja necessidade de aprimorar e aprofundar alguns pontos.

Por outro lado, o entrevistado da Fibria sempre demonstrou preocupação com a comunicação dos resultados de PH, bem como sua interpretação, e defende que os valores obtidos devem ser usados internamente, contribuindo com a gestão da água na empresa. Deste modo, se posiciona contra a comparação dos valores de PH entre diferentes produtos, pois entende que se trata de processos produtivos diferentes e não tem significado comparar distintas coisas.

Assim, usada como uma ferramenta de apoio à gestão da água em todo o processo produtivo da celulose, o informante da Fibria acredita que a contabilização da PH se tornará mais valiosa quando certificações em relação à água forem demandadas por seus stakeholders $^{49}$, principalmente clientes, como é o caso do FSC. Nesse sentido, explica que a decisão de adotar práticas ambientais voluntárias na Fibria, além do que é exigido pela legislação ambiental, é movida pelo fato de haver algum tipo de ganho pela empresa. Como ele explica, esse ganho pode ser em termos econômicos diretos, por exemplo, na redução do valor pago pelo uso da água, ou também indiretos, como efeitos positivos em relação à

\footnotetext{
${ }^{49}$ Por exemplo, a certificação da Alliance for Water Stewardship (AWS) recentemente lançada.
} 
reputação e imagem, que podem ser medidos, por exemplo, no ISE BM\&FBOVESPA e DWSI.

Para o representante da Fibria, a maior contribuição do setor corporativo para enfrentar os desafios relacionados à água é em primeiro lugar, contabilizando seu consumo. Considera, portanto, que há espaço para um refinamento na produção de dados e informações sobre uso da água na cadeia produtiva da celulose e também para todos os outros setores industriais. Em segundo lugar, identificando onde é possível atuar e por fim, definindo metas a médio e longo prazo. Considera também que fazer parte de redes sobre água mantém a empresa atualizada e facilita seu posicionamento diante dos novos temas que surgem.

De acordo com a entrevista, no caso da Fibria, há a pretensão de incluir a PH azul e PH cinza no Índice de Desempenho Ambiental (IDA), de modo a remunerar os funcionários à medida que as PH vão sendo reduzidas. Porém ainda não está claro como e quando isso terá início.

O posicionamento estratégico da Fibria em relação à sustentabilidade é identificado pela empresa como uma vantagem competitiva. Isso é demonstrado pela valorização de suas ações por fazer parte do Dow Jones Sustainability Index e do Índice de Sustentabilidade Empresarial da BM\&FBOVESPA.

Porém, cada vez mais os valores intangíveis têm sido considerados na empresa, ao reconhecer, por exemplo, a importância de se obter uma licença social para operar suas atividades. Nesse sentido, o entrevistado entende que para a Fibria a contribuição da utilização da PH até o momento se encaixa perfeitamente nesse segundo aspecto, já que não acredita que a PH irá ajudá-la a vender celulose.

\subsection{Síntese Analítica dos Casos Estudados}

A racionalidade ecológica tem sido internalizada pelas empresas no Brasil a partir de meados da década de 1990, principalmente depois da conferência Rio 92. É nessa época que o conceito de ecoeficiência é desenvolvido e o desempenho ambiental passa a ser considerado dentro das empresas (HOFFMAN, 1997; WBCSD, 2013). Desta forma, o posicionamento das empresas sobre as questões socioambientais passa a ser estratégico uma vez que pode oferecer vantagens competitivas em um mercado cada vez mais globalizado (BANERJEE, 2002). 
Nesse sentido, de acordo com o entrevistado, o posicionamento da Fibria em relação à temática da sustentabilidade é descrita como uma estratégia que agrega um diferencial que permite competir no mercado internacional, geralmente mais exigente às questões socioambientais. Essa questão da sustentabilidade como estratégia da empresa é apontada pelo entrevistado pelo fato da empresa compor os índices de sustentabilidade da Dow Jones e BM\&FBOVESPA.

Tal posicionamento se alinha com as principais ideias que explicam a emergência de uma agenda empresarial pautada por temas socioambientais, seja para atender a legislação ambiental vigente, seja para ir além do previsto em lei (ABRAMOVAY, 2012; BANERJEE, 2002; PORTER; LINDE, 1995).

No caso da Natura, o compromisso com as questões socioambientais emerge logo no início de sua atuação no mercado, ao optar, por exemplo, pela venda direta a partir de 1974 e ao oferecer aos consumidores refil de alguns de seus produtos (NATURA, 2014). Ao considerar o histórico da Natura em adotar práticas e iniciativas que minimizem parte de seus impactos socioambientais negativos, nota-se que a empresa busca sempre manter-se na vanguarda deste tema.

Ao mesmo tempo, é relevante considerar que a Natura, além de uma empresa de capital aberto como a Fibria, também é uma marca. Assim, como sugerem Sojamo e Larson (2012), empresas com estas características se relacionam com uma maior diversidade de stakeholders e por esta razão estão sujeitas a mais cobranças e contestações do que empresas de capital fechado, por exemplo.

Para as duas empresas estudadas a água é considerada um tema estratégico, presente na sua matriz de materialidade, realizada com a participação de diferentes stakeholders, internos e externos.

Os temas definidos na matriz de materialidade colaboram para direcionar a gestão, orientando projetos e iniciativas das operações das empresas e são reportados nos relatórios anuais. Por exemplo, a água passa a ser um tema prioritário para a Natura entre 2010 e 2011, quando houve a revisão da sua matriz de materialidade e a água foi incluída. A PH surge nos relatórios de sustentabilidade da Natura a partir de 2010 como sendo a ferramenta para realizar o diagnóstico do impacto das atividades da empresa sobre a água (NATURA, 2011). 
O último relatório de sustentabilidade da Natura disponível para consulta, referente ao ano de 2013, menciona que a PH servirá como base para a implementação de estratégias de redução e neutralização do impacto à água das atividades da Natura, de toda a cadeia produtiva (NATURA, 2013).

Com relação à Fibria, a água faz parte da sua matriz de materialidade desde $2009^{50}$, desenvolvida com a participação de stakeholders externos, nacionais e internacionais, incluindo clientes, fornecedores, parceiros e ONGs (FIBRIA, 2009). A estratégia da Fibria em utilizar a PH é mencionada pela primeira vez nos seus relatórios de sustentabilidade em 2010 e, como consta em seus relatórios de sustentabilidade, sua utilização pela Fibria tem como objetivo aumentar a ecoeficiência no uso da água no processo produtivo da celulose (FIBRIA, 2012).

Diante disso, a utilização da Pegada Hídrica entra na agenda das duas empresas estudadas por uma decisão interna por integrantes da gerência das empresas, sem que tenha havido exigência direta de clientes ou consumidores. De acordo com estudo realizado por Singh et al. (2014), os agentes internos, principalmente aqueles que ocupam altos cargos de gestão nas empresas, são responsáveis por pressionar a adoção de práticas proativas de gestão ambiental. Ao mesmo tempo, outros autores identificam que a regulação governamental e os mercados são muito importantes para a implantação de medidas proativas pelas empresas (HOFFMAN, 2000; MOON, 2007).

Por outro lado, quando observamos mais atentamente as informações coletadas nas entrevistas, percebemos que o representante da Fibria menciona que seus clientes europeus demonstram interesse pelos impactos socioambientais causados pela cadeia produtiva da celulose, mesmo não exigindo que a empresa comprove como maneja seus impactos sobre a água. Já a entrevistada da Natura comenta que já foi questionada por alguns de seus consumidores sobre o impacto que o uso do seu óleo de banho pode causar à qualidade da água.

Estas observações se alinham às ideias presentes na Teoria dos Stakeholders (FREEDMAN, 1984) e também na Nova Sociologia Econômica (ABRAMOVAY, 2012; SMELSER; SWELDEBERG, 2005) que defendem que tanto as empresas podem ser influenciadas por stakeholders externos à elas, como em muitos casos elas elaboram respostas para atender a estes interesses e permanecerem no mercado.

\footnotetext{
${ }^{50}$ Ano no qual a Fibria foi formada a partir da junção da empresa VCP com Aracruz Celulose.
} 
É possível perceber então que ao elaborarem sua matriz de materialidade com a colaboração dos diversos stakeholders, internos e externos, as empresas acabam sendo influenciadas pelas preocupações e interesses que não necessariamente estão relacionados com o lucro para seus acionistas e sócios (FREEMAN; LIEDTKA, 1991). Com isto, espera-se que as empresas adotem metas para lidar com os desafios identificados coletivamente e que tornem públicas suas atividades e desempenho em relação aos temas prioritários (TINOCO, 2010; VOIVODIC; BEDUSCHI FILHO, 2011).

Sendo assim, ainda que sutilmente e indiretamente, a cobrança dos diferentes stakeholders por transparência e informações em relação ao desempenho socioambiental, adicionado à oportunidade de ganhos financeiros para as empresas alinhadas com os ideais de conservação ambiental, explica as razões pelas quais a problemática ambiental, e mais especificamente às questões sobre água, passam a fazer parte da agenda corporativa (PORTER; LINDE, 1995).

Outro aspecto referente à elaboração da matriz de materialidade das empresas é sua característica antecipatória. Deste modo, o processo de construção da matriz, identificando os temas prioritários a serem gerenciados, se bem conduzido e realizado a partir de um diálogo com os diferentes stakeholders, pode ajudar a antecipar a riscos e contornar conflitos, inclusive sobre a água.

Deste modo, como apontam Hommel e Godard (2001), o delineamento de estratégias de antecipação a futuras contestações sociais, elaborado pelas empresas e seus stakeholders, evita que as empresas tenham sua imagem desgastada, prejudicando sua reputação e causando prejuízos financeiros. Nesse sentido, a utilização da $\mathrm{PH}$ pode contribuir para diagnosticar onde é possível atuar na redução do consumo de água, permitindo também a gestão antecipada de riscos atrelados à água.

Assim, a escolha da Natura e da Fibria pela adoção da PH para abordar a questão da água deu-se pelas mesmas razões em ambos os casos. Ou seja, porque a PH considera o consumo da água em toda a cadeia produtiva, permitindo uma visão mais ampla do que os métodos convencionais de contabilização de água, que costumam enfatizar a fase industrial.

Este resultado corrobora com aqueles encontrados no capítulo anterior, nos quais 21 dos 23 dos documentos analisados justificam a escolha do uso da PH tendo em vista as 
"vantagens do método" "51. Ou seja, por tratar-se de um método que possui características que possibilitam maior compreensão da relação entre a água e um determinado processo produtivo, sendo possível identificar também quais são as fases, processos e ingredientes que são mais intensivos no consumo e na contaminação da água.

Do mesmo modo, ambas as empresas afirmaram que os resultados dos estudos de $\mathrm{PH}$ conduzidos em cada organização serviram, principalmente, para compreender a pressão que cada fase de sua cadeia produtiva exerce sobre a água. Novamente, os resultados obtidos nos estudos de caso estão alinhados àqueles encontrados na revisão sistemática da literatura.

Assim, os resultados obtidos, tanto da revisão sistemática de literatura como nos estudos de caso, indicam que a utilização da $\mathrm{PH}$ responde à principal pergunta das empresas quando iniciam um estudo de PH, que é entender como se dá o consumo de água em todas as fases do sistema produtivo. Nesse sentido, nos dois estudos de caso apresentados, o método foi prioritariamente utilizado com a intenção de promover um olhar interno em relação à água, já que não mencionaram a possibilidade de engajar todos os elos de suas cadeias produtivas.

Os entrevistados das duas empresas estudadas consideram que a divulgação dos resultados de $\mathrm{PH}$ pode gerar problemas na interpretação por aqueles que não compreendem a abordagem proposta no método de cálculo, porém mesmo assim a entrevistada da Natura publicou trabalhos científicos com os valores de $\mathrm{PH}$ calculados para seus produtos e negócios.

Entretanto, a escolha pela não divulgação dos resultados também é feita por outras várias empresas que já realizaram estudos de $\mathrm{PH}$ em seus processos ou negócios, porque não sabem qual será o impacto destas informações ao público geral e órgãos governamentais (informação verbal ${ }^{52}$ ).

Nesse sentido, preocupação que as empresas têm demonstrado com a divulgação dos resultados dos estudos de PH indica que a licença social de operação tem sido cada vez mais considerada pelas empresas. A licença social de operação de uma empresa está relacionada com a percepção que a sociedade tem dos impactos, positivos ou negativos, das atividades da empresa na comunidade onde ela está inserida. É uma construção informal e dinâmica que requer constante diálogo entre a empresa e seus stakeholders. Deste modo, as empresas reconhecem que o alcance da pressão realizada por algumas ONGs, reforçada pelas

\footnotetext{
${ }^{51}$ Uma das categorias a partir da revisão bibliográfica sistemática (Capítulo 7).

52 Informação dada pelo Coordenador de Água Doce do Programa de Conservação da Mata Atlântica e das Savanas Centrais da TNC, em 23/05/2014 por Skype.
} 
ferramentas de comunicação que ampliam a visibilidade de eventos negativos associados às atividades das empresas, podem comprometer sua imagem e causar danos financeiros (THOMSON; BOUTILIER, 2011; LYNCH-WOOD; WILLIAMSON, 2007).

A problemática da interpretação dos resultados de $\mathrm{PH}$ mencionados pelas duas empresas pode ser explicada ainda pela ainda incipiente consciência ecológica e sistêmica que observamos na nossa sociedade. Essa situação é reproduzida no sistema educacional que pouco aborda as questões socioambientais e quando o faz, ainda é de maneira bastante compartimentada e pontual (JACOBI et al., 2011).

Para que esse quadro mude torna-se necessário inserir políticas públicas de formação para a sustentabilidade, transversais e constantes, em todos os níveis e espaços educacionais, formais e não formais. Deste modo, a médio e longo prazo os cidadãos poderão desenvolver um olhar crítico sobre a relação entre a sociedade e o ambiente natural e suas consequências.

Assim, apesar de a PH ter como principal vantagem a contabilização do volume de água de toda a cadeia produtiva, não foram tomadas decisões pelas empresas a partir dos resultados obtidos nos estudos de $\mathrm{PH}$ conduzidos, até a data das entrevistas ${ }^{53}$. Durante a entrevista, o entrevistado da Fibria menciona uma possível intervenção para diminuir o consumo de água nos viveiros de mudas de eucalipto, enquanto seu relatório de sustentabilidade de 2012 aponta que com o estudo de PH concluído, pretende-se identificar onde é possível atuar para que haja diminuição do consumo de água ${ }^{54}$ (FIBRIA, 2012).

A Natura, por sua vez, está envolvida com o desenvolvimento do indicador que capte os efeitos deletérios dos seus produtos sobre a qualidade da água (NATURA, 2013), que possa ser usado de maneira complementar na tomada de decisão para elaboração de produtos e escolha de ingredientes (algo equivalente à PH cinza), conforme sugerem Fang et al. (2014).

De acordo com Hoekstra et al. (2011), a fase de avaliação da sustentabilidade da PH, mesmo ainda em desenvolvimento em alguns aspectos, é o momento em que os dados obtidos podem ser utilizados para além dos limites das empresas, considerando a situação da bacia

\footnotetext{
${ }^{53}$ A entrevista com a informante da Natura foi realizada no dia 26/11/13 e com o informante da Fibria no dia $05 / 12 / 13$.

${ }^{54}$ No relatório de 2013, edição disponível mais recente, o termo "pegada hídrica" aparece uma vez, associado com avanços importantes obtidos pela empresa como a redução da PH (FIBRIA, 2013, p. 8). No entanto não foi encontrado em nenhum relatório de sustentabilidade disponível na sua página na Internet valores de PH, metas ou ações para redução da $\mathrm{PH}$ da celulose.
} 
hidrográfica em questão. É a partir desta avaliação que, segundo os autores, a PH pode ser capaz de contribuir com a melhora da gestão da água naquela região hidrográfica.

Nesse sentido, apesar de a avaliação de sustentabilidade da PH ser capaz de prover informações interessantes para a Fibria, além da questão da falta de disponibilidade de dados, como indica o entrevistado o custo de um estudo detalhado para uma empresa é maior do que o benefício coletivo resultante de uma avaliação como esta.

A questão dos custos poderia ser solucionada, por exemplo, por meio de uma parceria com outras empresas localizadas na mesma bacia hidrográfica e o setor público, ONGs e universidades, minimizando os custos individuais e maximizando os benefícios coletivos para todos os usuários da área em questão.

Outra possível solução para a obtenção de dados poderia ser a utilização dos planos de bacia hidrográfica como fonte de dados secundários para a elaboração da avaliação da sustentabilidade da $\mathrm{PH}$, como indica o entrevistado da TNC (informação verbal ${ }^{55}$ ).

Conforme apontam alguns autores, a aproximação entre diversos atores para enfrentar problemas comuns, incluindo as empresas, pode ser mais eficiente na elaboração de respostas e acelerar o processo em direção a um ambiente mais equilibrado (ER et al., 2012; MOL, 2010; BUTTEL, 2003).

Entretanto, esta questão nos remete à dificuldade de delimitar as responsabilidades atribuídas às empresas e ao setor público em relação à água, quando, por exemplo, a representante da Natura observa, a partir de seus resultados, que o uso de seus produtos rinsáveis impacta a qualidade da água dos corpos d'água, mas que a situação é agravada pela falta de coleta e tratamento de esgoto doméstico em algumas regiões do Brasil.

Deste modo, há uma linha tênue entre os limites de atuação do setor púbico e do setor empresarial na manutenção da disponibilidade hídrica para os diferentes fins, que sofrem influência direta da qualidade das instituições governamentais e sua capacidade de regulação e fiscalização (LAMBOOY, 2011).

\footnotetext{
${ }^{55}$ Informação dada pelo Coordenador de Água Doce do Programa de Conservação da Mata Attântica e das Savanas Centrais da TNC, em 23/05/2014 por Skype.
} 
Diante desta complexa atribuição das responsabilidades, Ruggie (2008) afirma que os governos têm o dever de proteger os seus cidadãos contra violações dos direitos humanos e que as empresas têm a responsabilidade de respeitá-los.

Aplicando esta diferenciação para o caso da água, que é considerada um direito humano (ONU, 2010), os governos devem, antes de tudo, garantir o acesso a todos os usuários e realizar uma gestão transparente, evitando a captação de água de maneira abusiva e sua contaminação. As empresas, por sua vez, devem consumir água para as suas atividades de maneira que não inviabilizem os outros usos previstos em lei, assumindo sua responsabilidade socioambiental corporativa (LAMBOOY, 2011; ONU, 2011). Nesse sentido, a autora argumenta ainda que as responsabilidades pelo uso da água por parte das empresas deveria ser maior nas regiões com maior fragilidade legal por parte dos governos e onde já se observa risco de escassez hídrica. Além disso, reconhece também que as empresas podem utilizar a discussão em torno da sustentabilidade do uso da água como uma oportunidade para prevenir problemas que afetem sua permanência no mercado, antecipando-se a regulações mais rígidas ou à contestação social, que prejudica a imagem da empresa (LAMBOOY, 2011).

É possível observar então a necessidade do Estado atuar como regulador para a manutenção e proteção dos recursos naturais, presente na teoria da modernização ecológica (MOL; JÄNICKE, 2000) e apontado também por Hoekstra (2014) quando argumenta que as empresas tem uma capacidade limitada de atuação, apesar de sua relevância e importância em direção ao uso responsável da água. A principal questão levantada por Hoekstra (2014) está relacionada com o atual padrão de consumo que reforça o aumento do consumo de água para atender as demandas por alimentos e outros bens.

Entretanto, ainda que seja limitada a atuação do setor empresarial, sua responsabilidade em atuar para reduzir o consumo de água deve ser assumida. Nesse sentido, de acordo com alguns autores, a emergência das alterações climáticas e dos riscos atrelados à água (físicos, regulatórios, reputacionais e/ou financeiros) tem feito com que as empresas utilizem ferramentas, entre elas a PH, para produzir informações, antecipando-se e minimizando os riscos que podem estar expostas (HEPWORTH, 2012; MORRISON et al., 2010).

Porém, conforme os entrevistados, ambas as empresas estudadas nesta pesquisa não consideram que enfrentam riscos em relação à disponibilidade hídrica nos locais onde suas 
plantas industriais estão instaladas e tampouco onde suas matérias primas são cultivadas. Ressalta-se também que nenhum outro tipo de risco foi mencionado.

Sobre a incapacidade de perceber os riscos, é interessante ressaltar que a planta industrial da Natura está localizada na bacia do Alto Tietê, bacia hidrográfica que apresenta um quadro socioambiental complexo, devido à densidade populacional e falta de planejamento urbano (JACOBI et al., 2013) que tem sido agravado com a possível falta de água divulgada nos últimos meses.

Ainda, a maior parte da PH total obtida nos estudos realizados tanto na Natura como na Fibria é composta da $\mathrm{PH}$ verde, uma vez que praticamente todas as culturas não são irrigadas, utilizando a água da chuva para seu crescimento ${ }^{56}$.

Assim, apesar de o cultivo agrícola não irrigado ser defendido por seu baixo custo de oportunidade (ALDAYA et al., 2010), alguns autores indicam que é preciso discutir os tradeoffs entre uso do solo e consumo de água verde, além de recomendarem que os serviços ecossistêmicos provisionados sejam avaliados nestes locais (WILLAARTS et al., 2012; JEWITT, 2006).

Além disso, não foi mencionada pelos entrevistados preocupação com as alterações climáticas, que podem provocar, por exemplo, alterações nos regimes de precipitação (NOBRE et al., 2010; IPCC, 2013) afetando inclusive as áreas de culturas não irrigadas produzidas para serem usadas pela Natura e Fibria, podendo causar impactos futuros na produtividade das empresas.

Deste modo, apesar de os entrevistados não terem demonstrado que a questão dos riscos tenha prioridade, os relatórios de sustentabilidade de 2013 tanto da Natura como da Fibria apresentam um capítulo sobre gestão de riscos que incluem diferentes temas socioambientais como pontos que merecem atenção das empresas. Nesse sentido, as duas empresas possuem iniciativas para identificar riscos, não diretamente associados à água, mas sobre temas econômicos, socioambientais, imagem e reputação das empresas, por exemplo (FIBRIA, 2013; NATURA, 2013).

Sobre as limitações que o método apresenta, a entrevistada da Natura concluiu principalmente, que o indicador de impacto sobre a qualidade da água, a PH cinza, não serve

\footnotetext{
${ }^{56}$ A Fibria tem irrigação somente na fase inicial dos viveiros, antes de as mudas de eucalipto serem plantadas nas áreas silvícolas.
} 
para a empresa tomar decisões, concordando com os argumentos de Cucek et al. (2012), de que trata-se de um volume teórico que não atende a situação real.

Ao mesmo tempo, é importante lembrar que o conceito de PH cinza tem servido como base para que a empresa desenvolva um indicador capaz de mostrar os impactos causados à qualidade da água pela perspectiva da ecotoxicidade e biodegradabilidade dos produtos, conforme sugerido por Empinotti et al. (2013). As autoras argumentam que o reconhecimento de fatores como, por exemplo, o impacto dos poluentes à saúde humana ou vida aquática tornaria o indicador PH cinza uma ferramenta que possa contribuir com a melhoria da qualidade da água e dos ecossistemas aquáticos com um todo (EMPINOTTI et al., 2013).

O representante da Fibria, ao contrário, argumenta que mesmo sendo um valor teórico, a redução da PH cinza pode ser usada como medida de eficiência do tratamento de efluentes decorrentes das atividades da empresa.

É importante ressaltar que o valor de PH cinza indica a quantidade de água necessária para diluir determinado composto químico até chegar aos limites máximos permitidos por lei. Assim, apesar de ser um volume teórico, ele traz consigo a noção de que deve existir um limite para o lançamento de efluentes para que o ambiente aquático mantenha seu equilíbrio.

Retomando as opiniões do entrevistado sobre os pontos críticos referentes à $\mathrm{PH}$, a Fibria indica ressalvas em relação à comparação dos resultados de $\mathrm{PH}$ entre produtos, assim como Empinotti et al. (2013) e Postle et al., (2011), que argumentam que o ato de comparar os valores totais de PH não considera as condições socioambientais, tecnológicas e climáticas nas quais determinados bens são produzidos.

Se por um lado os estudos conduzidos pela Natura permitiram perceber que a PH não se enquadra perfeitamente aos objetivos da empresa, porque não permite que decisões sejam tomadas no seu processo produtivo, por outro lado a Natura reconhece aspectos positivos sobre a PH. Por exemplo, de acordo com a entrevistada da Natura, a PH pode ser uma boa ferramenta de sensibilização para diferentes stakeholders que fazem parte da cadeia produtiva da empresa, pois é capaz de indicar que a água é um recurso fundamental para qualquer processo produtivo. E mesmo não sendo uma ferramenta de comunicação ambiental, a PH possui potencial para ser usada com este propósito, como também foi observado na revisão bibliográfica sistemática. 
O entrevistado da Fibria, por sua vez, reconheceu que as empresas não detêm o controle do consumo de água de todas as fases do processo produtivo como se poderia pensar e, nesse sentido, o estudo de PH permitiu que houvesse aprendizado entre os participantes. Jacobi (2012), a partir da noção de aprendizagem social, aponta que por meio de processos integrados, de cooperação e negociação entre diferentes stakeholders em torno de um tema comum, é possível estimular mudanças de comportamento que tragam benefícios e cooperação.

Para concluir, é possível identificar nos relatos que as duas empresas estudadas reconhecem de que o setor empresarial é capaz de contribuir para ampliar o uso responsável da água, cada uma a partir de sua cultura organizacional. A Natura, pelo caminho da comunicação, transparência, parceria e pelo reconhecimento da ideia de compartilhamento das responsabilidades entre os diversos stakeholders. A Fibria através de medições e metas de redução do consumo de água, ou seja, medidas de ecoeficiência.

Para Hepworth (2012), as maneiras pelas quais as empresas tentam compreender a questão da água e seus riscos associados influenciam a estratégia das respostas resultantes, que poderão ser mais ou menos abrangentes, internas ou externas, pontuais ou processuais, ou ainda poderão ser iniciativas individuais das empresas ou configurar parcerias ou cooperação.

A abordagem proposta pela $\mathrm{PH}$, por ser mais abrangente e apresentar novas maneiras de entender o consumo de água na cadeia produtiva e de perceber as possíveis formas de relação entre os diferentes stakeholders, como toda construção, precisa de tempo para ser de fato incorporada nas estratégias das empresas e resultar em mudanças positivas na relação entre a água e os padrões de produção e consumo.

Os resultados apresentados e discutidos neste capítulo a partir dos estudos de caso com duas grandes empresas brasileiras indicam que os desafios em relação à água abordados por uma perspectiva mais ampla sobre seu consumo, são um tema recentemente incorporado na agenda empresarial. Sendo assim, é esperado que as estratégias das empresas estudadas para lidar com o tema sejam abordadas de uma maneira convencional, focada em ações internas e voltadas às melhores práticas (DANIEL; SOJAMO, 2012).

Ao mesmo tempo, nota-se que existe, por parte das empresas estudadas, o reconhecimento de que seu funcionamento depende cada vez mais da licença social de operação. Ainda que os desdobramentos resultantes da utilização da PH pelas empresas 
estudadas sejam pouco concretas para promover o consumo responsável e sustentável da água dentro do setor empresarial, olhar para além dos seus processos industriais é um caminho que, ao que tudo indica, será cada vez mais necessário para desenvolver habilidades para enfrentar os desafios em relação à água em um mundo globalizado. 


\section{Considerações Finais}

A análise dos fatores que motivam o engajamento das empresas na problemática associada à água a partir de uma perspectiva mais ampla, como a proposta pela Pegada Hídrica, é particularmente interessante para a concepção de respostas que sejam progressivas e ao mesmo tempo construtivas, visando uma gestão mais equitativa e sustentável da água pelo setor empresarial.

A apropriação de ideias de diferentes referenciais teóricos utilizados neste trabalho permitiram uma discussão mais ampla sobre os motivos que têm levado as empresas a utilizar a avaliação da PH como método para abordar a temática da água em seus processos produtivos. Nesse sentido, é importante ressaltar o caráter inter e multidisciplinar desta pesquisa, que mobilizou inicialmente as possibilidades de conciliar os desafios ambientais com a questão econômica, ao apresentar as ideias centrais da teoria da modernização ecológica. Além desta abordagem, foram trazidos para compor a estrutura base deste trabalho aspectos interessantes presentes na teoria dos stakeholders e nova sociologia econômica, que colaboram na compreensão sobre as influências que as empresas sofrem por diferentes stakeholders externos a elas, pela perspectiva de que os mercados são uma construção social e estão inseridos na sociedade.

Deste modo, a partir da descrição da linha do tempo (Capítulo 6), é possível observar como as discussões internacionais em torno da água migram da liderança em âmbito da ONU, que até meados dos anos 90 orientava este processo, para eventos e conferências organizados por instituições internacionais compostas por diferentes representantes, como o setor empresarial, governos e ONGs.

Isso demonstra, por um lado, a progressiva apropriação do discurso de gestão descentralizada e participativa da água por parte de outros atores, além do Estado. Por outro lado, a ideia de que a responsabilidade pelo uso sustentável da água deve ser compartilhada, inclusive pelo setor empresarial, vai sendo difundida.

Ao mesmo tempo, os mecanismos de governança internacional para enfrentar a problemática da água têm se demonstrado insuficientes, por exemplo, devido à dificuldade de se estabelecerem acordos multilaterais ou ainda por implicações que afetem a soberania 
nacional dos países envolvidos. Nesse sentido, observa-se um campo propício para o surgimento de iniciativas que envolvem diferentes setores, como o setor empresarial e ONGs.

Neste processo, a água tem ganhado destaque e é identificada pelo setor empresarial como um recurso fundamental para a manutenção de suas atividades. Ao mesmo tempo, percebe-se que o setor tem capacidade de atuar para que assuma sua responsabilidade pelo uso da água.

Assim, diferentes iniciativas e ferramentas têm sido desenvolvidas para auxiliar as empresas neste desafio de abordar as questões associadas à água, seja para identificar a pressão causada pela relação entre produção e consumo, como pretende a $\mathrm{PH}$, ou identificar e mapear riscos. Ou ainda, para aprimorar e fortalecer a transparência e a comunicação entre as empresas e seus stakeholders, externos e internos.

Devido à repercussão e visibilidade dada à PH na comunidade internacional e sua recente apropriação pelo setor empresarial, este trabalho teve como foco compreender as razões que têm levado as empresas a utilizarem-na para abordar as questões sobre água nos seus processos produtivos.

A partir do referencial teórico utilizado, e considerando o aumento da necessidade de água para atender as demandas de produção e consumo, a hipótese inicial da pesquisa foi elaborada considerando que os riscos atrelados à água (riscos físicos, regulatórios, reputacionais e financeiros) seriam os vetores principais que justificariam a utilização do indicador Pegada Hídrica pelo setor empresarial.

Porém, os resultados obtidos indicam que, ao contrário da hipótese inicial desta pesquisa, os riscos associados à água não foram considerados os principais vetores que têm levado as empresas a utilizarem a PH para abordar a temática da água. Mesmo presentes nos documentos analisados na revisão sistemática de literatura (Capítulo 7), nos estudos de caso (Capítulo 8) a questão dos riscos não foi mencionada pelas duas empresas brasileiras estudadas. Cabe relembrar que apesar de estarem em bacias hidrográficas complexas, no momento das entrevistas com a Fibria e Natura não havia nenhuma menção à crise hídrica que tem afetado o Estado de São Paulo neste ano de 2014.

Os documentos analisados no Capítulo 7, na revisão bibliográfica sistemática, apontaram que o principal motivo que levaram às empresas a utilizar a PH está associado com as vantagens que o método oferece para compreender melhor sua relação (e dependência) com 
a água. Por exemplo, a avaliação da $\mathrm{PH}$ considera volumes de água indiretos e também classifica o tipo de água de acordo com sua fonte e impacto. Por esta razão é possível identificar qual fase da cadeia produtiva causa mais pressão à água, seja pelo consumo ou pela contaminação da água por meio do lançamento de efluentes. Ou ainda, identificar quais são os ingredientes que mais consomem água.

Essas informações se tornam mais importantes quando se considera ainda que a cadeia produtiva de diferentes produtos muitas vezes é composta por processos que estão localizados em diferentes países, aumentando a complexidade da compreensão da pressão e impactos negativos causados à água.

A segunda questão identificada a partir da revisão bibliográfica sistemática sobre a utilização da $\mathrm{PH}$, diz respeito ao seu potencial comunicador e articulador, que pode ser utilizado para fortalecer o engajamento entre os diferentes stakeholders que uma empresa se relaciona. Isso inclui os fornecedores de matéria prima ou subprodutos, trabalhadores, acionistas e sócios, clientes, consumidores, governos e comunidades locais onde as empresas mantém qualquer uma de suas atividades. No entanto, este aspecto potencial do método não foi muito enfatizado nos estudos de caso.

Desta forma, a partir da utilização da $\mathrm{PH}$ em um processo produtivo, a responsabilidade poderia ser compartilhada entre todos os envolvidos no ciclo de vida dos produtos. Isso estimula e fortalece o diálogo entre todos os elos da cadeia produtiva, aumentando a capacidade de produção e publicização de informações, e ainda amplia a capacidade de oferecer respostas coletivas que minimizem o impacto negativo das atividades socioeconômicas à água, beneficiando a sociedade e os ecossistemas aquáticos.

Uma abordagem mais completa do uso e consumo da água se torna relevante e contribui para as empresas entenderem que também são responsáveis pelos impactos negativos causados à água em todas as etapas de suas cadeias produtivas. Essa responsabilidade compartilhada deveria alcançar inclusive os cidadãos, que muitas vezes, por falta de informações, no ato de consumir legitimam práticas que são ambientalmente e socialmente insustentáveis e injustas.

Deste modo, a redução do consumo de água usada nos processos produtivos das empresas, além da minimização das perdas, é extremamente necessária considerando ainda o cenário de incertezas referente às alterações climáticas e seus efeitos sobre o ciclo 
hidrológico. Nesse sentido, a PH poderá ser útil para identificar os volumes de consumo de água apropriados pela humanidade para a produção de bens e serviços, mas também para monitorar a sustentabilidade destes processos.

Porém, como argumentado em capítulos anteriores, ações de otimização do uso da água por parte das empresas são insuficientes quando se considera os limites dos recursos hídricos para atender ao atual padrão de produção e consumo.

O que torna interessante, e o que se conclui a partir de todos os resultados apresentados neste trabalho, é que, mesmo incipiente, a mudança de comportamento das empresas em relação à água também é pautada pelos temas discutidos na agenda internacional global. Assim o tema água é internalizado tornando-se estratégico para as empresas, de acordo com as informações obtidas nos estudos de caso.

Como já discutido anteriormente, a $\mathrm{PH}$ como indicador de consumo de água é perfeitamente aplicável às empresas, aos seus processos produtivos e cadeia de valor, contribuindo no diagnóstico do consumo da água de uma maneira mais ampla e integrada, devido às vantagens que o método traz consigo. Mas, por se tratar de uma prática recente, não é possível medir ainda a contribuição da aplicação da PH na mudança do posicionamento das empresas em relação à água. Para isso, pesquisas futuras que acompanhem a evolução desse processo serão necessárias para orientar ações.

No entanto, é necessário lembrar que os desafios associados à água são bastante complexos, pois compreendem disputas, poderes assimétricos, conflitos e interesses que muitas vezes são antagônicos. Além disso, a questão da água está associada a outras questões, como por exemplo, o uso e a ocupação do solo, o que aumenta os desafios relacionados à sua gestão, resultando frequentemente em injustiças ambientais a grupos sociais mais vulneráveis.

Portanto, para enfrentar todos os desafios inerentes à temática da água é necessário ir além da aplicação do indicador PH e da elaboração de respostas por parte do setor empresarial. Claro que esse é o primeiro passo e é muito importante, como foi explicado em diversos momentos nesta tese. Porém, é preciso considerar os limites naturais das bacias hidrográficas em relação à disponibilidade hídrica e capacidade de autodepuração dos rios receptores de efluentes. Nesse sentido, o Estado tem papel fundamental como orientador de práticas que pretendam alcançar a sustentabilidade no uso da água e garantir os diferentes usos. 
Desse modo, mesmo que as empresas continuem agindo para maximizar seus lucros, está cada vez mais claro que a sociedade ao exigir transparência dos impactos negativos e positivos causados pelo setor corporativo, pode por um lado, se tornar uma ameaça ao questionar e contestar o desempenho socioambiental das empresas e, por outro, se tornar seu maior aliado para enfrentar o grande desafio inerente à temática da água e outros recursos naturais.

Entretanto, ainda existe um longo e complexo caminho a ser construído para que os limites ecossistêmicos sejam internalizados pelas empresas de modo que a água deixe de ser mais um insumo necessário para a manutenção de suas atividades. Parte deste caminho passa pela percepção da água como um recurso natural que, além de fundamental para a garantia de todas as formas de vida, faz parte de um complexo e integrado sistema maior, e que, portanto, merece um debate público condizente com sua importância.

\section{Questões para Pesquisas Futuras}

No decorrer do desenvolvimento deste trabalho surgiram diversas questões que estimulam a realização de pesquisas futuras em torno da relação entre empresas e água. Considerou-se apropriado, portanto, incluir este capítulo final com sugestões de trabalhos futuros, dadas as questões que emergiram a partir das categorias elaboradas nesta Tese. Uma das sugestões para a realização de estudos é relacionada com a percepção de riscos associados à água pelas empresas, tendo em vista a diferença entre o reconhecimento dos riscos apontados na literatura e os estudos de caso realizados.

Outro aspecto que pode ser mais aprofundado é a utilização da Pegada Hídrica como uma ferramenta facilitadora de comunicação e engajamento dos stakeholders da cadeia produtiva das empresas. Os resultados obtidos na revisão bibliográfica sistemática indicam que a $\mathrm{PH}$ pode ser utilizada para este fim, por isso seria interessante um estudo que confirme ou não essa possibilidade. Outro tema de pesquisa pode ser associado à capacidade da $\mathrm{PH}$ servir também como um instrumento que facilite a aprendizagem social, seja dentro das organizações ou ainda em um comitê de bacia hidrográfica.

Uma terceira possibilidade seria aprofundar também a pesquisa sobre a relação entre a utilização da PH e a tomada de decisão sobre temas relacionados à água pelas empresas, 
questão apontada principalmente nos artigos científicos analisados neste trabalho. Essa questão é importante, pois permite avaliar qual é de fato a contribuição da PH para as empresas, já que o motivo para a sua utilização, obtido neste trabalho, está relacionado com a ampliação da compreensão sobre o uso da água na cadeia produtiva. $\mathrm{O}$ passo seguinte, depois do diagnóstico realizado, deveria ser, portanto, a tomada de decisão e alteração de comportamento organizacional sobre questões relacionadas à água. Por esta razão um estudo mais detalhado com as empresas que já usaram a PH poderia trazer informações interessantes sobre o alcance do método. Nesse sentido questões sobre a problemática do greenwashing pelas empresas também poderiam ser abordadas.

Além disso, dada a necessidade de repensar os atuais padrões de consumo em razão de seu impacto socioambiental, uma possibilidade de investigação poderia ser a exploração do potencial da PH como uma ferramenta pedagógica. A utilização do conceito de PH em práticas educacionais pode ser um caminho inovador de sensibilização sobre os impactos do consumo à água para públicos diversos.

Longe de esgotar as oportunidades de futuras investigações que surgiram a partir do desenvolvimento desta pesquisa, a intenção é de levantar questões que possam contribuir para uma melhor compreensão da complexa relação entre sociedade, empresas e água. 


\section{Referências Bibliográficas}

ABRAMOVAY, R. 2007. Bem-vindo ao mundo da controvérsia. In: Veiga, J.E. (Org.), Transgênicos - Sementes da Discórdia. São Paulo: SENAC.

ABRAMOVAY, R., VOIVODIC, M.A., CARDOSO, F.C., CONROY, M.E. 2010. Social Movements and NGO in the construction of new market mechanisms. Economic Sociology European Eletronic Newsletter, v. 11, n. 2, p. 24-30.

ABRAMOVAY, R. 2012. Muito além da economia verde. São Paulo: Editora Abril, 248 p.

ACSELRAD, H., MELLO, C.C.A., BEZERRA, G.N. 2009. O que é justiça ambiental? Rio de Janeiro, Ed. Garamond, 160 p.,

ALDAYA, M.M., LLAMAS, M.R. 2008. Water footprint analysis for the Guadiana river basin, Value of Water Research Report Series n.35, UNESCO-IHE.

ALDAYA, M.M., MARTINEZ-SANTOS, P., LLAMAS, M.R. 2010. Incorporating the water footprint and virtual water into policy: Reflections from the Mancha Occidental Region, Spain, Water Resources Management, n. 24, v. 5, p. 941-958.

ALLAN, J. A. 1998. Virtual Water: a strategic resource, global solutions to regional deficits. Groundwater, v. 36, n. 4, p. 545-546.

ALLAN, J. A. 2003. Virtual Water - the water, food and trade nexus. Useful concept or misleading metaphor? Water International, v. 28, n.1, p. 4-10.

ALLAN, T. 2011. Virtual Water-Tackling the threat to our planet's most precious resource. London: I.B Tauris e Co, 368p.

ANA. Agência Nacional de Águas. 2013. Conjuntura dos recursos hídricos no Brasil. Brasília: ANA.

ASSOCIAÇÃO BRASILEIRA DE ÁGUAS SUBTERRÂNEAS. 2014. Ano Mundial da Água. Disponível em: http://www.abas.org/abasinforma/141/paginas/03.htm Acesso em: 24/04/2014.

AWS. ALLIANCE FOR WATER STEWARDSHIP. 2014a. Alliance for Water Stewardship. Disponível em: http://www.allianceforwaterstewardship.org/ Acesso em: 24/04/2014.

AWS. ALLIANCE FOR WATER STEWARDSHIP. 2014b. The AWS International Water Stewardship Standard. Disponível em: http://www.allianceforwaterstewardship.org/what-wedo.html\#water-stewardship-standard Acesso em: 11/03/2014.

BANERJEE, S.B. 2002. Corporate Environmentalism - The construct and its measurement. Journal of Business Research, v. 55, p. 177-191.

BANERJEE, S.B. 2008. Corporate social responsibility: The good, the bad and the ugly. Critical Sociology, v. 34, n. 1, p. 51-79.

BARLOW, M. 2009. Água Pacto Azul - a crise global da água e a batalha pelo controle da água potável no mundo. M. Books do Brasil Editora, São Paulo, 200 p. 
BEEKMAN, W., VELDWISCH, G.J. 2012. The evolution of the land struggle for smallholder irrigated rice production in Nante, Mozambique. Physics and Chemistry of the Earth, v. 50-52, p. 179-184.

BIER. BEVERAGE INDUSTRY ENVIRONMENTAL ROUNDTABLE. 2011. A practical perspective on water accounting in the beverage sector. Beverage Industry Environmental Roundtable. Disponível em: http://www.waterfootprint.org/Reports/BIER-2011WaterAccountingSectorPerspective.pdf Acesso em: 10/05/2013.

BUDAPEST WATER SUMMIT. 2014. Overview. Disponível em: http://www.budapestwatersummit.hu/budapest-water-summit/overview/ Acesso em: 09/05/14.

BULSINK, F., HOEKSTRA, A.Y., BOOIJ, M.J. 2010. The water footprint of Indonesian provinces related to the consumption of crop products, Hydrology and Earth System Sciences, v. 14,n. 1p. 119-128.

BUTTEL, F.H. 2003. Environmental Sociology and the explanation of environmental reform. Organization Environment, v.16, p. 306-344.

CARMO, R.L., OJIMA, A.L.R.O., OJIMA, R., NASCIMENTO, T.T. 2007. Água virtual, escassez e gestão: O Brasil como grande exportador de água. Ambiente e Sociedade, v. 10, n. 1, p. 83-96.

CAROLAN, M.S. 2004. Ecological Modernization Theory: what about consumption? Society \& Natural Resources, v. 17, n. 3, p. 247-260.

CARROLL, A.B. 1979. A Three-Dimensional Conceptual Model of Corporate Performance. The Academy of Management Review, v. 4, n. 4, p. 497-505.

CARROLL, A.B. 1999. Corporate Social Responsibility - Evolution of a Defitional Construct. Business \& Society, v. 38, n. 3, p. 268-295.

CARROLL, A.B., SHABANA, K.M. 2010. The Business Case for Corporate SocialResponsibility: A Review of Concepts, Research and Practice. International Journal of Management Reviews, v. 12, n. 1, p. 85-105.

CASHORE, B. 2002. Legitimacy and the Privatization of Environmental Governance: How Non-State Market-Driven (NSMD) Governance Sysytems Gain Rule-Making Authority. Disponível em: http://yale.edu/forestcertification/pdfs/2002/02_new_gove_nmsd.pdf Acesso em: 24/04/2014.

CDP. CARBON DISCLOSURE PROJECT.. 2013. Global Water Report- Moving beyond business as usual - Reporting 2013. Disponível em: https://www.cdp.net/CDPResults/CDPGlobal-Water-Report-2013.pdf Acesso em: 05/03/2014.

CDP. CARBON DISCLOSURE PROJECT .2014. CDP Water Disclosure - Reporting to CDP's Water Program. Disponível em: https://www.cdp.net/en-US/Respond/Pages/CDPWater-Disclosure.aspx Acesso em: 05/03/2014.

CEO WATER MANDATE. 2014a. Sobre o CEO Water Mandate. Disponível em: http://ceowatermandate.org/about/ Acesso em: 14/03/2014. 
CEO WATER MANDATE. 2014b. What's tools are available? Disponível em: http://ceowatermandate.org/water-assessment-tools-methods/what-tools-are-available/ Acesso em: 10/03/2014.

CERES. 2014. Drinving Improvement in Water Stewardship - Agua Gauge. Disponível em: https://www.ceres.org/issues/water/aqua-gauge Acesso em: 10/03/2014.

CHAPAGAIN, A.K., HOEKSTRA, A.Y., SAVENIJE, H.H.G. 2006a. Water saving through international trade of agricultural products, Hydrology and Earth System Sciences, v. 10, n. 3, p.455-468.

CHAPAGAIN, A.K., HOEKSTRA, A.Y., SAVENIJE, H.H.G. GAUTAM, R. 2006b. The water footprint of cotton consumption: An assessment of the impact of worldwide consumption of cotton products on the water resources in the cotton producing countries. Ecological Economics, v.60, n.1, p 186-203.

CHAPAGAIN, A.K., ORR, S. 2008. UK water footprint: The impact of the UK's food and fibre consumption on global water resources. Surrey: WWF-UK.

CHAPAGAIN, A., TICKNER, D. 2012. Water Footprint: Help or Hindrance? Water Alternatives, v.5, n.3, p. 563-581.

CHICO, D., ALDAYA, M.M., GARRIDO, A. 2013. A water footprint assessment of a pair of jeans: the influence of agricultural policies on the sustainability of consumer products. Journal of Cleaner Production, v. 57, p. 238-248.

CHRISTOFF, P. 1996. Ecological Modernization, Ecological Modernities. Environmental Politics, v. 5., n. 3, p. 476-500.

CNI. Confederação Nacional da Indústria. 2013. Água, indústria e sustentabilidade. CNI: Brasilia, 224 p.

COCA-COLA EUROPE. 2011. Water footprint sustainability assessment: Towards sustainable sugar sourcing in Europe, Brussels, Belgium. Disponível em: http://www.waterfootprint.org/Reports/CocaCola-2011-

WaterFootprintSustainabilityAssessment.pdf Acesso em: 14/06/2013.

CONFORTO, E.C., AMARAL, D.C., DA SILVA, S.L. 2011. Roteiro para revisão bibliográfica sistemática: aplicação no desenvolvimento de produtos e gerenciamento de projetos. Anais do $8^{\circ}$ Congresso Brasileiro de Gestão de Desenvolvimento de Produto, Porto Alegre, RS.

CONROY, M. 2007. Branded! How the certification revolution is transforming global corporations. Gabriola Island, Canadá. New Society Publishers.

CORPORATE SUSTAINABILITY FORUM, 2012. Overview and outcomes: innovation and collaboration, public policy recommendations and commitments to action. Disponível em: http://www.unglobalcompact.org/docs/news_events/upcoming/RioCSF/RioCorpSustForum_ Outcome_21June12.pdf Acesso em: 07/05/2014.

COSGROVE, W. 2013. Water Futures: the evolution of water scenarios. Current Opinion in Environmental Sustainability, v. 5, p. 559-565. 
COSGROVE, W. J., RIJSBERMAN, F.R. 2000. World Water Vision - Disponível em: http://www.worldwatercouncil.org/fileadmin/world_water_council/documents_old/Library/W WVision/spWW00.pdf Acesso em: 14/09/2013.

CUCEK, L., KLEMES, J.J., KRAVANJA, Z. 2012. A review of a Footprint analysis tools for monitoring impacts on sustainability. Journal of Cleaner Production, v. 34, p. 9-20.

CUNHA, T.B., OLIVEIRA, D.B.S., LINHARES, F.M., SANTOS, J.Y.G., VIANNA, P.C.G. 2010. Uma sinopse da política mundial da água. Anais do XVI Encontro Nacional de Geógrafos. Porto Alegre. 25 a 30 de julho.

DANIEL, M.A., SOJAMO, S. 2012. From risks to shared value? Corporate strategies in building a global water accounting and disclosure regime. Water Alternatives, v. 5, n.3, 636657.

DEURER, M., GREEN, S.R., CLOTHIER, B.E., MOWAT, A. 2011. Can product water footprints indicate the hydrological impact of primary production? - A case study of New Zealand kiwifruit. Journal of Hidology, v. 408, p. 246-256.

DONAIRE, D. 1994. Considerações sobre a influência da variável ambiental na empresa. Revista de Administração de Empresas, v. 34, n. 2, p. 68-77.

DUBLIN STATEMENT. 1992. The Dublin Statement on water and sustainable development. Disponível em: http://www.un-documents.net/h2o-dub.htm Acesso em: 05/09/2013.

DUMONT, A., SALMORAL, G., LLAMAS, M.R. 2013. The water footprint of a river basin with a special focus on groundwater: The case of Guadalquivir basin (Spain). Water Resources and Industry, v. 1-2, p. 60-76.

EMPINOTTI, V.L., TADEU, N.D., MARTINS, R.S.L. 2013. Análise crítica da Pegada Hídrica cinza na produção de celulose. Ambiente e Água, v. 8, n. 3, p. 166-177.

ENE, S.A., TEODOSIU, C., ROBU, B., VOLF, I. 2013. Water footprint assessment in the winemaking industry: a case study for a Romanian medium size production plant. Journal of Cleaner Production, v. 43, p. 122-135.

ER, A.C., MOL, A.P.J., (KRIS) van KOPPEN, C.S.A. 2012. Ecological Modernization in selected Malaysian industrial sectors: political modernization and sector variations. Journal of Cleaner Production, v. 24, p. 66-75.

ERCIN, A.E., ALDAYA, M.M., HOEKSTRA, A.Y. 2011. CorporateWater Footprint Accounting and Impact Assessment: The Case of the Water Footprint of a Sugar-Containing Carbonated Beverage. Water Resources Management, v. 25, n. 2, p. 721-741.

EWING B., MOORE, D., GOLDfiNGER, S., OURSLER, A., REED, A., WACKERNAGEL, M., 2010. Ecological Footprint Atlas 2010. Global Footprint Network, Oakland. Disponível em: http://www.footprintnetwork.org/images/uploads/Ecological_Footprint_Atlas_2010.pdf Acesso em: 12/03/2014.

FADER, M., GERTEN, D., THAMMER, M., HEINKE, J., LOTZE-CAMPEN, H., LUCHT, W., CRAMER, W. 2011. Internal and external green-blue agricultural water footprints of 
nations, and related water and land savings through trade, Hydrology and Earth System Sciences, v. 15, n. 5, p. 1641-1660.

FANG, K., HEIJUNGS, R., SNOO, G.R. 2014. Theoretical exploration for the combination of the ecological, energy, carbon, and water footprints: Overview of a footprint family. Ecological Indicators, v. 36, p. 508-518.

FARIA, A., SAUERBRONN, F.F. 2008. A responsabilidade social é uma questão de estratégia? Uma abordagem crítica. Revista de Administração Pública, v. 42, n. 1, p. 07-33.

FIBRIA. 2009. Relatório de Sustentabilidade 2009. Disponível em: http://www.fibria.com.br/rs2009/shared/rs2009_pt.pdf Acesso em: 12/07/2014.

FIBRIA. 2012. Relatório de Sustentabilidade 2012. Disponível em: http://www.fibria.com.br/rs2012/pt/ Acesso em: 04/05/2014.

FIBRIA. 2013. Relatório de 2013 - Firmes no rumo. Disponível em: http://www.fibria.com.br/relatorio2013/shared/relatorio-de-2013-firmes-no-rumo20maio2014.pdf Acesso em: 10/06/2014.

FIBRIA. 2014. Fibria - Apresentação Corporativa (Junho 2014). Disponível em: http://fibria.infoinvest.com.br/ptb/5780/Corporativa_Junho_Port2.pdf Acesso em: 10/06/2014.

FISHER, D.R., Freudenburg, W.R. 2001. Ecological Modernization and Its Critics: Assessing the Past and Looking Toward the Future. Society \& Natural Resources: An International Journal, v. 14, n. 8, p. 701-709.

FINKBEINER, M. 2009. Carbon footprinting-opportunities and threats. International Journal of Life Cycle Assessment, v. 14, p. 91-94.

FOURTH WATER FORUM. 2014. Ministerial Declaration. Disponível em: http://www.worldwaterforum4.org.mx/home/..\%5Cfiles\%5CDeclaraciones\%5CMinisterialDe claration.pdf Acesso em: 17/10/2013.

FRANCKE, I.C.M., CASTRO, J.F.W. 2013. Carbon and water footprint analysis of a soap bar produced in Brazil by Natura Cosmetics. Water Resources and Industry, v. 1-2, p. 37-48.

FRANCKE, N., BOYACIOGLO, H., HOEKSTRA, A.Y. 2013. Grey Water Footprint accounting - Tier 1 Supporting Guidelines. Value of Water Research Report Series $\mathrm{n}^{\mathrm{o}}$. 65 UNESCO-IHE, Delft, The Netherlands.

FRANCKE; MATHEWS, 2013a C\&A's Water Footprint Strategy: Cotton Clothing Supply Chain. Disponível em: http://www.waterfootprint.org/Reports/CA_Strategy_Final_Report_Formatted\%2006.08.2013 .pdf Acesso em: 25/05/2014.

FRANKE, N., MATHEWS, R. 2013b. Grey Water Footprint Indicator of Water Pollution in the Production of Organic vs. Conventional Cotton in India. Disponível em: http://www.waterfootprint.org/Reports/Grey\%20WF\%20Phase\%20II\%20Final\%20Report_Fo rmatted\%2006.08.2013.pdf Acesso em: 25/05/2014. 
FREEMAN, R.E. 1984 Strategic Management: A Stakeholder Approach (Boston: Pitman Publishing Inc.).

FREEMAN, R.E., LIEDTKA, J. 1991. Corporate Social Responsibility: a critical approach. Business Horizons, v. 34, n. 4, p. 92.

FRIEDMAN, M. 1970. The Social Responsibility of Business is to Increase its Profits, New York Times Magazine, 13 de setembro de 1970. Disponível em: http://www.colorado.edu/studentgroups/libertarians/issues/friedman-soc-resp-business.html Acesso em: 05/02/2014.

FRIENDS OF THE EARTH INTERNATIONAL (FOEI). 2014. Send a letter to reclaim the UN from corporate capture. Disponível em: http://www.foei.org/en/get-involved/takeaction/reclaim-the-un-from-corporate-capture Acesso em: 16/05/2014.

GALli, A., WIEDMANN, T., ERCIN, E., KNOBLAUCH, D., EWING, B., GILJUM, S., 2012. Integrating ecological, carbon and water footprint into a "footprint family" of indicators: definition and role in tracking human pressure on the planet. Ecological Indicators, v. 16, p. 100-112.

GAN, Y., ZHANG. T., LIANG, S., ZHAO, Z., LI, NAN. 2013. How to Deal with Resource Productivity: Relationships Between Socioeconomic Factors and Resource Productivity. Journal of Industrial Ecology, v. 17, n. 3, p. 440-451.

GARRIDO, A., LLAMAS, R.M., VARELA-ORTEGA, C., NOVO, P., RODRÓGUEXCASADO, R.; ALDAYA, M.M. 2010. Water Footprint and Virtual Water Trade in Spain: Policy Implications. Fundación Botin e Springer. 150 p.

GEMI, 2012. GEMI Local Water Tool. Disponível em: http://www.gemi.org/localwatertool/ Acesso em: 06/03/14.

GERBENS-LEENES, P.W., MEKONNEN, M.M., HOEKSTRA, A.Y. 2013. The water footprint of poultry, pork and beef: A comparative study in different countries and production systems, Water Resources and Industry, v. 1-2, p. 25-36.

GONÇALVES-DIAS, S.L.F., TEODÓSIO, A.S.S. 2011. Perspectivas de análise do ambientalismo empresarial para além de demonizações e santificações. Revista de Gestão Social e Ambiental, v. 5, n. 2, p. 03-17.

GRANOVETTER, M. 1985. Economic action and social structure: the problem of embeddedness. American Journal of Sociology, v. 91, n. 3, p. 481-510.

GREENPEACE. 2012. Greenwash+20: How some powerful corporations are standing in the way of sustainable development. Disponível em: <http://www.greenpeace.org/international/en/publications/Campaign-reports/ClimateReports/GreenwashPlus20/ Acesso em: 16/05/2014.

GUIMARÃES, R., FONTOURA, Y. 2012. Rio + 20 ou Rio - 20? Crônica de um fracasso anunciado. Ambiente e Sociedade, v. 15, n. 3, p. 19-39.

GWP. GLOBAL WATER PARTNERSHIP. 2000. Towards Water Security: A framework for action. 
http://www.gwp.org/Global/GWPSAm_Files/Publicaciones/Marco\%20para\%201a\%20Accion /framework-for-action-part-1.pdf Acesso em: 16/09/2013.

GWP. GLOBAL WATER PARTNERSHIP. 2013. History. Disponível em: http://www.gwp.org/en/About-GWP/History/ Acesso em: 09/09/2013.

HAJER, M. 1995. The Politics of Environmental Discourse. Ecological modernization and the policy process. Oxford: Clarendon Press

HEPWORTH, N. 2012. Open for business or Opening Pandora's box? A constructive critique of corporate engagement in Water Policy: An introduction. Water Alternatives, v. 5, n. 3, p. 543-562.

HERATH, I., GREEN, S., HORNE, H., SINGH, R., MCLAREN, S., CLOTHIER, B. 2013. Water footprinting of agricultural products: evaluation of different protocols using a case study of New Zealand wine. Journal of Cleaner Production, v. 44, p. 159-167.

HERTZOG , T.; ADAMCZEWSKI, A.; MOLLE, F.; POUSSIN J.-C., JAMIN, J.-Y. 2012. Ostrich-like strategies in sahelian sands? Land and water grabbing in the Office du Niger, Mali. Water Alternatives, v. 5, n. 2, p. 304-321.

HERVA, M., FRANCO, A., CARRASCO, E.F., ROCA, E. 2011. Review of corporate environmental indicators. Journal of Cleaner Production, v. 19, p. 1687-1699.

HOEKSTRA, A.Y.,HUNG, P.Q. 2002. Virtual water trade: A quantification of virtual water flows between nations in relation to international crop trade, Value of Water Research Report Series No.11, UNESCO-IHE.

HOEKSTRA, A.Y., HUNG, P.Q. 2005. Globalisation of water resources: international virtual water flows in relation to crop trade, Global Environmental Change, v. 15, n. 1, p.45-56.

HOEKSTRA, A.Y., CHAPAGAIN, A.K.2007. Water footprints of nations: water use by people as a function of their consumption pattern, Water Resources Management. v. 21, n.1, p35-48.

HOEKSTRA, A. Y. 2009. Human appropriation of natural capital: A comparison of ecological footprint and water footprint analysis. Ecological Economics v. 68, p. 1963-1974.

HOEKSTRA, A.Y. 2011. The global dimension of water governance: Why the river basin approach is no longer sufficient and why cooperative action at global level is needed, Water, v. 3, n.1, p. 21-46.

HOEKSTRA, A.Y., CHAPAGAIN, A.K., ALDAYA, M.M., MEKONNEN, M.M. 2011. The water footprint assessment manual: Setting the global standard, Earthscan, London, UK.

HOEKSTRA, A.Y., MEKONNEN, M.M., CHAPAGAIN, A.K., MATHEWS, R.E., RICHTER, B.D. 2012. Global monthly water scarcity: Blue water footprints versus blue water availability, PLoS ONE, v. 7, n. 2 e32688.

HOEKSTRA, A.Y.,MEKONNEN, M.M. 2012. The water footprint of humanity, Proceedings of the National Academy of Sciences, v. 109, n. 9, p. 3232-3237. 
HOEKSTRA, A.Y. 2014. Water scarcity challenges to business, Nature Climate Change, v. 4, n. 5 , p. $318-320$.

HOEKSTRA, A.Y., WIEDMANN, T.O. 2014. Humanity's unsustainable environmental footprint, Science, v. 344, n. 6188, p. 1114-1117.

HOFFMAN, A.J. 1997. From heresy to dogma - An institutional history of corporate environmentalism. São Francisco, California, The New Lexington Press, 253 p.

HOFFMAN, A.J. 2000. Integrating environmental and social issues into corporate practice. Environment, v. 42, n. 5, p. 22-33.

HOMMEL, T.,GODARD, O. 2001. Contestation sociale et stratégies de développement industriel. Application du modèle de la Gestion Contestable à la production industrielle d'OGM, Cahier École Polytechnique, Laboratoire d'Économétrie n 2001-015.

HOMMEL, T. 2004. Stratégies des firmes industrielles et contestation sociale. Paris: Cemagref/Cirad/Ifremer/Inra.

IBGE. INSTITUTO BRASILEIRO DE GEOGRAFIA E ESTATÍSTICA. 2010. Pesquisa Nacional de Saneamento Básico 2008. Rio de Janeiro. Disponível em:

http://www.ibge.gov.br/home/estatistica/populacao/condicaodevida/pnsb2008/PNSB_2008.pd f Acesso em: 05/03/2014.

INTERNATIONAL FINANCE CORPORATION, LIMNOTECH, JAIN IRRIGATION SYSTEMS, THE NATURE CONSERVANCY. 2010. Water footprint assessments Dehydrated onion products, Micro-irrigation systems - Jain Irrigation Systems Ltd., International Finance Corporation, Washington, D.C., USA.

INTERNATIONAL CONFERENCE ON FRESWATER. 2001. Conference Report: Watera key to sustainable development. Disponível em: http://www.un.org/esa/sustdev/sdissues/water/BonnConferenceReport.pdf Acesso em: 18/09/2013.

INTERNATIONAL CONFERENCE ON WATER AND SUSTAINABLE DEVELOPMENT. $1998 . \quad$ Final Declaration. Disponível em: http://www.ramsar.org/cda/en/ramsar-news-archives-1998-international-conference21038/main/ramsar/1-26-45-91\%5E21038_4000_0__Acesso em: 12/09/2013.

IPCC. INTERGOVERNMENTAL PANEL ON CLIMATE CHANGE. Summary for Policymakers. In: Climate Change 2013: The Physical Science Basis. Contribution of Working Group I to the Fifth Assessment Report of the Intergovernmental Panel on Climate Change.Stocker, T.F., D. Qin, G.-K. Plattner, M. Tignor, S.K. Allen, J. Boschung, A. Nauels, Y. Xia, V. Bex and P.M. Midgley (eds.). Cambridge University Press, Cambridge, United Kingdom and New York, NY, USA. Disponível em: http://www.climatechange2013.org/images/report/WG1AR5_SPM_FINAL.pdf Acesso em: 04/03/2014.

IPCC. INTERGOVERNAMENTAL PANEL ON CLIMATE CHANGE. 2014. Assessments Reports. Disponível em: http://www.ipcc.ch/ Acesso em: 15/05/2014. 
ISE. ÍNDICE DE SUSTENTABILIDADE EMPRESARIAL. 2014. Apresentação do ISE. Disponível em: https://www.isebvmf.com.br/index.php?r=site/conteudo\&id=1\# Acesso em: 18/02/2014.

ISTAMBUL WATER CONSENSUS. 2009. Istambul Water Consensus. Disponível em: http://www.worldwatercouncil.org/fileadmin/world_water_council/documents_old/World_W ater_Forum/WWF5/Istanbul_Water_Consensus_Eng_Final.pdf Acesso em: 28/04/2014.

JACOBI, P.R., MONTEIRO, F., FERNANDES, M.L.B. 2011. Educação e Sustentabilidade Caminhos e práticas para uma educação transformadora. Ed. Evoluir Cultural, São Paulo, $108 \mathrm{p}$.

JACOBI, P.R. 2012. Pegada Hídrica e aprendizagem social - o desafio de ampliar interações sociais. In: Pegada Hídrica: inovação, corresponsabilização e os desafios de sua aplicação. Empinotti e Jacobi (Org.). São Paulo, Annablume. 176 p.

JACOBI, P.R., SINISGALLI, P.A.A. 2012. Governança ambiental e economia verde. Ciência \& Saúde Coletiva, v. 17, n. 6, p. 1469-1478.

JACOBI, P.R., PAZ, M.G.A., SOUZA LEÃO, R., ESTANCIONE, L.M.B. 2013. Water governance and natural disasters in the Metropolitan Region of São Paulo, Brazil, International Journal of Urban Sustainable Development, v. 5, n. 1, p. 77-88.

JEFFERIES, D., MUÑOZ, I., HODGES, J., KING, V.J., ALDAYA, M., ERCIN, A.E, MILÀ I CANALS, L., HOEKSTRA, A.Y. 2012. Water Footprint and Life Cycle Assessment as approaches to assess potential impacts of products on water consumption. Key learning points from pilot studies on tea and margarine. Journal of Cleaner Production, v. 33, p. 155-166.

JEWITT, G., 2006. Integrating blue and green water flows for water resources management and planning. Physics and Chemistry of the Earth, v. 31, n. 15-16, p. 753-762.

JOHANNESBURG SUMMIT. 2002. Key outcomes of the Summit. Disponível em: http://www.un.org/jsummit/html/documents/summit_docs.html Acesso em: 18/09/2013.

JOHNSON, S. 2012. UNEP. The first 40 years: A narrative. Disponível em: http://www.unep.org/pdf/40thbook.pdf Acesso em: 30/08/2013

JONES, C. 2010. Exploring new ways of assessing the effect of regulation on environmental management. Journal of Cleaner Production, v. 18, p. 1229-1250.

KARNANI, A. 2014. Corporate Social Responsibility Does Not Avert the Tragedy of the Commons - Case Study: Coca-Cola India. Ross School of Business Working Paper Series, February 2014. Disponível em:

http://www.indiaresource.org/documents/KalaDera/TragedyCommonsCocaColaIndiaKarnani Feb2014.pdf Acesso em: 05/03/2014.

KIMBERLY-CLARK, 2014. Kimberly-Clark realiza estudo de Pegada Hídrica. Sala de Imprensa. Disponível em: https://www.kimberly-clark.com.br/novo/Sala-de-Impresa.aspx Acesso em: 09/06/2014.

LAMBOOY, T. 2011. Corporate Social Responsability: Sustainable water use. Journal of Cleaner Production, v. 19, p. 852-866. 
LARSON, E.A. 2011. Corporate social responsibility and transboundary flows of virtual water: Bringing multinational food companies into a political economic discussion of water security. Master Dissertation, King’s College London, Universidade de Londres.

LARSON, W.M., FREEDMAN, P.L., PASSINSKY, V., GRUBB, E., ADRIAENS, P. 2012. Mitigating corporate water risk: Financial market tools and supply management strategies. Water Alternatives, v. 5, n. 3, p. 582-602.

LEIS, H. R., D'AMATO, J. L. 2005. Para una teoría de las prácticas del ambientalismo mundial Theomai. Disponível em: http://www.redalyc.org/articulo.oa?id=12420823003 Acesso em: 29/08/13

LÓPEZ-GUNN, E., LLAMAS, M.R. 2008. Re-thinking water scarcity: Can science and technology solve the global water crisis? Natural Resources Forum, v. 32, p. 228-238.

LYNCH-WOOD, G., WILLIAMSON, D. 2007. The social licence as a form of regulation for a small and medium enterprises. Journal of Law and Society, v. 34, n. 3, p. 321-341.

MA, J., HOEKSTRA, A.Y., WANG, H., CHAPAGAIN, A.K., WANG, D. 2006. Virtual versus real water transfers within China, Phil. Trans. R. Soc. Lond. B. 361 v. 1469, p. 835842.

MARRAKECH DECLARATION. 1997. Declaração de Marrakech. Disponível em: http://contrattoacqua.it/public/upload/1/2/tab_elms_docs/1329754104marrakech_declaration. pdf Acesso em: 10/09/2013.

MARZULLO, R.C.M.,MATAI, P.H.L.S. 2012. A Pegada Hídrica com abordagem de avaliação de ciclo de vida (ACV). In: Empinotti e Jacobi (Org.), Pegada Hídrica: inovação, corresponsabilização e os desafios da sua aplicação. São Paulo: Annablume, 176 p.

MEHTA, L.; VELDWISCH, G.J.,FRANCO, J. 2012. Introduction to the Special Issue: Water grabbing? Focus on the (re)appropriation of finite water resources. Water Alternatives, v. 5, n. 2, p. 193-207.

MEKONNEN, M.M., HOEKSTRA, A.Y. 2010 A global and high-resolution assessment of the green, blue and grey water footprint of wheat, Hydrology and Earth System Sciences, v. 14, n. 7 , p. 1259-1276.

MEKONNEN, M.M., HOEKSTRA, A.Y. 2012. A global assessment of the water footprint of farm animal products, Ecosystems, v. 15, n. 3, p. 401-415.

MEKONNEN, M.M., HOEKSTRA, A.Y., BECHT, R. 2012. Mitigating the water footprint of export cut flowers from the Lake Naivasha Basin, Kenya, Water Resources Management, v. 26, p. $3725-3742$.

MEMON, P.A., KIRK, N.A., SELSKY, J.W. 2011. Limits to Ecological Modernisation as a framework for sustainable fresh water governance. Land Use Policy, v. 28, p. 534-541.

MENDONÇA, C.B., TADEU, N.D., SINISGALLI, P.A.A. 2013. Pegada Hídrica da bovinocultura de corte no Brasil: uma comparação entre a produção em pastagem manejada e não manejada. Anais do XX Simpósio Brasileiro de Recursos Hídricos da ABRH. 17 a $22 / 11 / 2013$.

Bento

Gonçalves,

$\mathrm{RS}$.

Disponível

em: 
http://www.abrh.org.br/SGCv3/UserFiles/Sumarios/8e1c5b6839cee533e1277929e6e2011e_6 ce62f2573afa3a30c00199db6dc86c8.pdf Acesso em: 17/03/2014.

MINAYO, M.C.S. (Org.). 2010. Pesquisa Social: teoria, método e criatividade. 29 ed.

Petrópolis, RJ: Vozes.

MINX, J.C., WIEDMANN, T., WOOD, R., PETERS, G.P., LENZEN, M., OWEN, A., SCOTT, K., BARRETT, J., HUBACEK, K., BAIOCCHI, G., PAUL, A., DAWKINS, E., BRIGGS, J., GUAN, D., SUH, S., ACKERMAN, F. 2009. Input-output analysis and carbon footprinting: an overview of applications, Economic Systems Research, v. 21, n. 3, p. 187216.

MOL, A.P.J. 2000. The environmental movement in an era of ecological modernisation. Geoforum, v. 31, p. 45-56.

MOL, A.P.J., JÄNICKE, M. 2000. The origins and theoretical foundations of ecological modernisation theory. In: Ecological Modernisation Around the World - Perspectives and Critical Debates. Mol, A.P.J. e Sonnenfeld (Ed). Frank Cass, London, Portland.

MOL, A.P.J., SPAARGAREN, G. 2000a. Ecological Modernisation Theory in Debate: A review. In: Ecological Modernisation Around the World - Perspectives and Critical Debates. Mol, A.P.J. e Sonnenfeld (Ed). Frank Cass, London, Portland.

MOL, A. P. J., SPAARGAREN, G. 2000b. Ecological Modernization Theory in Debate: a review. Environmental Politics, v. 9, n.1., p. 17-49.

MOL, A.P.J., SONNENFELD, D.A. 2000. Ecological Modernisation around the world: an introduction. Environmental Politics, v. 9, n. 1, p. 3-16.

MOL, A.P.J., SPAARGAREN, G. 2009. Ecological Modernisation and Industrial Transformation. In: Castree, N., Demeritt, D., Liverman, D., Rhoads, B. A Companion to Environmental Geography, Blackwell Publishing.

MOL, A.P.J. 2010. Social Theories of Environmental Reform: Towards a third generation. In: Gross, M. e Heirinchs, H. (Org.), Environmental Sociology: European Perspectives and Interdisciplinary Challenges, Dordrecht, Heidelberg, Londres, Nova Iorque. Springer. p. 1938.

MOON, J. 2007. The contribution of Corporate Social Responsibility to Sustainable Development. Sustainable Development, v. 15, p. 296-306.

MORI, K., CHRISTODOULOU, A. 2012. Review of sustainability indices and indicators: Towards a new City Sustainability Index (CSI). Environmental Impact Assessment Review, v. 32 , p. $94-106$.

MORRISON, J.; SCHULTE, P; SCHENCK, R. 2010. Corporate Water Accounting: An Analysis of Methods and Tools for Measuring Water Use and its Impacts. Oakland, UNEP, United Nations Global Compact and Pacific Institute.

NATURA. 2011. Relatório Natura 2011. Disponível em: http://natura.infoinvest.com.br/ptb/3996/RelatorioAnual_2011_completo_gri_port.pdf Acesso em: 10/06/2014. 
NATURA. 2013. Relatório Natura 2013. Disponível em: http://natura.infoinvest.com.br/ptb/4723/Rel_Nat_013_PRINT.pdf Acesso em: 10/06/2014.

NATURA. 2014. História da Natura. Disponível em: http://www.natura.com.br/www/anatura/sobre-a-natura/historia/ Acesso em: 20/06/2014.

NEWBORNE, P., MASON, N. 2012. The private sector's contribution to water management: re-examining corporate purposes and company roles. Water Alternatives, v.5, n. 3, p. 603618.

NICCOLUCCI, V., BOTTO, S., RUGANI, B., NICOLARDI, V., BASTIANONI, S., GAGGI, C. 2011.The real water consumption behind drinking water: The case of Italy. Journal of Environmental Management, v. 92, p. 2611-2618.

NOBRE, C.A., YOUNG A.F., SALDIVA P., MARENGO, J.A., NOBRE, A.D., JUNIOR, S.A., SILVA, G.C.M. DA, LOMBARDO, M. 2010. Vulnerabilidade das Megacidades Brasileiras às Mudanças Climáticas: Região Metropolitana de São Paulo, Sumário Executivo. São Paulo: INPE/UNICAMP/USP/IPT/UNESP Rio Claro.

O'CONNOR, J. 1994. Is sustainable capitalism possible? In: Is capitalism sustainable? Political Economy and the Politics of Ecology. Nova Iorque, The Guilfort Press, p. 152-175.

OELS, A. 2005. Rendering climate change governable: From biopower to advanced liberal government? Journal of Environmental Policy \& Planning, v. 7, n. 3, p. 185-207.

OKOLI, C., SCHABRAM, K. 2010. A Guide to Conducting a Systematic Literature Review of Information Systems Research. Sprouts: Working Papers on Information Systems, v. 10, n. $26 . \quad$ Disponível em: http://sprouts.aisnet.org/867/1/OkoliSchabram2010SproutsLitReviewGuide.pdf Acesso em: 05/06/2014.

ONU. ORGANIZAÇÃO DAS NAÇÕES UNIDAS. 1997a. UN Conference on Environment and Development 1992. Disponível em: http://www.un.org/geninfo/bp/enviro.html Acesso em: 05/09/2013.

ONU. ORGANIZAÇÃO DAS NAÇÕES UNIDAS. 1997b. Special session of general assembly on implementation of agenda 21 concludes at headquarters, 23 - 27 June. Disponível em: http://www.un.org/News/Press/docs/1997/19970627.GA9276.html Acesso em: $10 / 09 / 2013$.

ONU. ORGANIZAÇÃO DAS NAÇÕES UNIDAS. 2002. Report of the World Summit on Sustainable Development. Johannesburg. Disponível em: http://daccess-ddsny.un.org/doc/UNDOC/GEN/N02/636/93/PDF/N0263693.pdf?OpenElement Acesso em: 18/09/2013.

ONU. ORGANIZAÇÃO DAS NAÇÕES UNIDAS. 2010. The human right to water and sanitation. Resolution 64/292. Disponível em: http://www.un.org/es/comun/docs/?symbol=A/RES/64/292\&lang=E Acesso em: 04/03/2014.

ONU. ORGANIZAÇÃO DAS NAÇÕES UNIDAS. 2011. Guiding principles on Business ad Human Rights. Implementing the United Nations "Protect, respect and remedy" Framework. Disponível 
http://www.ohchr.org/Documents/Publications/GuidingPrinciplesBusinessHR_EN.pdf Acesso em: 01/07/2014.

ONU. ORGANIZAÇÃO DAS NAÇÕES UNIDAS. 2012. Rio + 20 - O futuro que queremos. Disponível em: http://www.onu.org.br/rio20/img/2012/03/Rio+20_Futuro_que_queremos_guia.pdf Acesso em: 05/05/2014.

ONU. ORGANIZAÇÃO DAS NAÇÕES UNIDAS. 2013. Temas mundiales - Medio Ambiente. Disponível em: http://www.un.org/es/globalissues/environment/ Acesso em 20/07/2013.

ONU. ORGANIZAÇÃO DAS NAÇÕES UNIDAS. 2013a. Programa 21, Capítulo 18. Disponível em: http://www.un.org/spanish/esa/sustdev/agenda21/agenda21spchapter18.htm Acesso em: 06/09/2013.

ONU. ORGANIZAÇÃO DAS NAÇÕES UNIDAS. 2013b. Millennium Development Goals. Disponível em: http://www.un.org/millenniumgoals/ Acesso em: 17/09/2013.

ONU. ORGANIZAÇÃO DAS NAÇÕES UNIDAS. 2013c. A ONU e o meio ambiente. Disponível em: http://www.onu.org.br/a-onu-em-acao/a-onu-e-o-meio-ambiente/Acesso em: 18/09/2013.

ONU. ORGANIZAÇÃO DAS NAÇÕES UNIDAS. 2013d. Water for life decade. Disponível em: http://www.un.org/waterforlifedecade/background.shtml Acesso em: 14/10/13.

ORR, S.; CARTWRIGHT, A.,TICKNER, D. 2009. Understanding water risks: A primer on the consequences of water scarcity for government and business. London: WWF-UK. Disponível em: http://assets.wwf.org.uk/downloads/understanding_water_risk.pdf Acesso em: 04/03/2014.

PALHARES, J.C.P. 2011. Pegada hídrica dos suínos abatidos nos Estados da Região CentroSul do Brasil. Acta Scientiarum. Animal Sciences, v. 33., n. 3, p. 309-314.

PEGRAM, G.; ORR, S., WILLIAMS, C. 2009. Investigating shared risk in water: Corporate engagement with the public policy process. Surrey, England: WWF-UK. Disponível em: http://assets.wwf.org.uk/downloads/investigating_shared_risk.pdf Acesso em: 04/03/2014.

PEÑA, C.A.; HUIJBREGTS, M.A.J. 2013.The BlueWater Footprint of Primary Copper Production in Northern Chile. Journal of Industrial Ecology, v. 18, n. 1, p. 49-58.

PERREAUlT, T., WRAIGHT, S., PERREAULT, M. 2012. Environmental injustice in the Onondaga lake waterscape, New York State, USA. Water Alternatives, v. 5, n. 2, p. 485-506.

PERRINI, F., TENCATI, A. 2006. Sustainability and Stakeholder Management: the Need for New Corporate Performance Evaluation and Reporting Systems. Business Strategy and the Environment, v. 15, p. 296-308.

PERRY, C. 2014. Water footprints: Path to enlightenment, or false trail? Agricultural Water Management, v. 134, p. 119-125. 
PHILLIPS, R., FREEMAN, R.E., WICKS, A.C. 2003. What stakeholder theory is not. Business Ethics Quartely, v. 13, n. 4, p. 479-502.

PIMENTEL, A. 2001. O método da análise documental: seu uso numa pesquisa historiográfica. Cadernos de Pesquisa, n. 114, p. 179-195.

PORTER, M. E., LINDE, C. van der. 1995. Toward a new conception of the environmentcompetitiveness relationship. The Journal of Economic Perspectives, v. 9, n. 4, p. 97-118.

POSTlE, M., GEORGE, C., UPSON, S., HESS, T., MORRIS, J. 2011. Assessment of the efficiency of the water footprinting approach and of the agricultural products and foodstuff labelling and certification schemes. Final Report Part A (Asssessment) for European Commission Directorate-General Environment. 198 p.

RAHAMAN, M.M.; VARIS, O.; KAJANDER, T. 2004. EU Water Framework Directive vs. Integrated Water Resources Management: The Seven Mismatches. Water Resources Development, v. 20, n. 4, p. 565-575.

RIBEIRO, W.C. 2008. Geografia Política da Água. Annablume, São Paulo, 162 p.

RIDOUT, B.G., EADY, S.J., SELLAHEWA, J., SIMONS, L., BEKTASH, R. 2009. Water footprinting at the product brand level: case study and future challenges. Journal of Cleaner Production, v. 17, p. 1228-1235.

RUINI, L., MARINO, M., PIGNATElli, S., LAIOC, F., RIDOLfiC, L. 2013. Water footprint of a large-sized food company: The case of Barilla pasta production.Water Resources and Industry, v. 1-2, p. 7-24.

SABMILLER, WWF-UK.2009. Water footprinting: Identifying \& addressing water risks in the value chain, SABMiller, Woking, UK / WWF-UK, Goldalming, UK.

SABMILLER, GTZ, WWF. 2010. Water futures: Working together for a secure water future, SABMiller, Woking, UK / WWF-UK, Goldalming, UK.

SCHNAIBERG, A., PELLOW, D.N., WEINBERG, A. 2000. The treadmill of production and the environmet state. Disponível em: http://www.ipr.northwestern.edu/publications/papers/urban-policy-and-communitydevelopment/docs/schnaiberg/treadmill-of-production.pdf Acesso em: 14/08/2014.

SEBASTIAN, A.G., WARNER, J.F. 2013. Geopolitical drivers of foreign investment in African land and water resources, African Identities. On line first.

SIKIRICA, N. 2011. Water footprint assessment bananas and pineapples, Dole Food Company, Soil \& More International, Driebergen, the Netherlands. Disponível em: http://www.waterfootprint.org/Reports/Soil-and-More-2011-

WaterFootprintBananasPineapplesDole.pdf Acesso em: 25/05/2014.

SILVA, J.S. 2008. Análise das diretrizes do plano nacional de recursos hídricos no contexto internacional de governança da água. Trabalho de conclusão de curso. Universidade Federal de Santa Catarina. 72p. Disponível em: http://www.gthidro.ufsc.br/arquivos/tcc-julia-santossilva.pdf 
SINGH, N., JAIN, S., SHARMA, P. 2014. Determinants of proactive environmental management practices in Indian firms: an empirical study. Journal of Cleaner Production, $\mathrm{v}$. 66, p. 469-478.

SMELSER, N.J., SWEDBERG, R. 2005. Introducing Economic Sociology. In: Smelser, N.J. e Swedberg, R. (Org.) The Handbook of Economic Sociology, 2a ed., Princeton University Press.

SOJAMO, S., LARSON, E.A. 2012. Investigating food and agribusiness corporations as global water security, management and governance agents: The case of Nestlé, Bunge and Cargill. Water Alternatives, v. 5, n. 3, p. 619-635.

SOJAMO, S., KEULERTZ, M., WARNER, J.; ALLAN, J.A. 2012. Virtual water hegemony: the role of agribusiness in global water governance. Water International, v. 37, n. 2, p. 169182.

SOUZA LEÃO, R, FERREIRA, J.G., FRACALANZA, A.P., JACOBI, P.R. 2014. Pegada Hídrica e reforma ambiental - Uma revisão de literatura. Atas do VIII Congresso Português de Sociologia: 40 anos de democracia(s): progressos, contradições e prospetivas. Évora, Portugal.

TADEU, N.D. 2014. A avaliação dos impactos hídricos da monocultura de eucalipto no trecho paulista da bacia hidrográfica do Rio Paraíba do Sul. Dissertação de Mestrado. Programa de Pós Graduação em Ciência Ambiental. Universidade de São Paulo. 176 p.

TADEU, N.D., SINISGALLI, P.A.A. 2013. Impactos hídricos de la producción de madera de eucalipto en area de mata atlântica en la cuenca del rio Paraiba do Sul, São Paulo, Brasil. Anais da VI Jornada de la Asociación Argentino Uruguaya de Economia Ecologica. Salta, 26 a 29/11/2013. Disponível em: http://www.asauee2013.com.ar/asaue/wpcontent/uploads/2013/11/2_10_Tadeu.pdf Acesso em: 20/03/2014.

THE COCA-COLA COMPANY, THE NATURE CONSERVANCY (2010) Product water footprint assessments: Practical application in corporate water stewardship, The Coca-Cola Company, Atlanta, USA / The Nature Conservancy, Arlington, USA.

THOMSON, I., BOUTILIER, R.G., 2011. Modelling and measuring the social license to operate: fruits of a dialogue between theory and practice. Disponível em: http://socialicense.com/publications/Modelling\%20and\%20Measuring\%20the\%20SLO.pdf Acesso em: 11/08/2014.

TINOCO, J. E. P. 2010. Balanço Social e o Relatório da Sustentabilidade (1 ed.). São Paulo: Atlas.

TOKE, D., STRACHAN, P.A. 2006. Ecological Modernization and Wind Power in the UK. European Environment, v. 16, p. 155-166.

UN WATER. UNITED NATIONS WATER. 2013. UN Water 10 years. Disponível em: http://www.unwater.org/downloads/UN-Water_brochure_Oct2013.pdf Acesso em: 15/10/13. 
UNITED NATIONS WATER. 2013a- International Year of Water Cooperation. Disponível em: http://www.unwater.org/water-cooperation-2013/events/closing/fr/ Acesso em: 09/05/2014.

UNEP. UNITED NATIONS ENVIRONMENT PROGRAMME. 2011. Water Footprint and corporate water accounting for resource efficiency. United Nations Global Compact, Pacific Institute. $184 \mathrm{p}$.

UNESCO. Organização das Nações Unidas para a Educação, Ciência e Cultura. 2013. Por que ano internacional de cooperação pela água? Disponível em: http://www.unesco.org/new/fileadmin/MULTIMEDIA/FIELD/Brasilia/pdf/brz_sc_year_wate r_cooperation_presskit_pt_2013-2.pdf Acesso em: 09/05/2014.

UNESCO. ORGANIZAÇÃO DAS NAÇÕES UNIDAS PARA A EDUCAÇÃO, CIÊNCIA E CULTURA. 2014. Dependencias de lós Recursos Hídricos - Sistemas sometidos a estrés y respuestas 2008-2013. sociales Disponível em: http://unesdoc.unesco.org/images/0018/001840/184030s.pdf Acesso em: 24/04/2014.

UNICEF. 2013. Objetivos de Desenvolvimento do Milênio. Disponível em: http://www.unicef.org/brazil/pt/resources_9540.htm Acesso em: 17/09/2013.

UNITED NATIONS GLOBAL COMPACT. 2014. Overview of the UN Global Compact. Disponível em: http://www.unglobalcompact.org/AboutTheGC/index.html Acesso em: $13 / 03 / 2014$.

UNGER, K., ZHANG, G., MATHEWS, R. 2013. Water Footprint Assessment Results and Learning: Tata Chemicals, Tata Motors, Tata Power, Tata Steel, Tata Quality Management Services, International Finance Corporation, Water Footprint Network.

UPM-KYMMENE. 2011. From forest to paper, the story of our water footprint, Helsinki, Finland.

Van OEL, P.R.; HOEKSTRA, AY. 2012. Towards Quantification of the Water Footprint of Paper: A First Estimate of its Consumptive Component. Water Resources Management, v. 26, p. 733-749.

VARGAS, M.C. 2005. O Negócio da Água: riscos e oportunidades das concessões de saneamento à iniciativa privada: estudos de caso no sudoeste brasileiro. São Paulo: Annablume. $270 \mathrm{p}$.

VELÁSQUEZ, E. 2007. Water trade in Andalusia. Virtual water: An alternative way to manage water use. Ecological Economics, v. 63, n. 1, p. 201-208.

VERMA, S., KAMPMAN, D.A., VAN DER ZAAG, P., HOEKSTRA, A.Y. 2009. Going against the flow: A critical analysis of inter-state virtual water trade in the context of India's National River Linking Programme, Physics and Chemistry of the Earth, v. 34, p. 261-269.

VIOLA, E., FRANCHINI, M. 2012. O sistema internacional de hegemonia conservadora: o fracasso da Rio +20 na governança dos limites planetários. Ambiente e Sociedade, v. 15, n. 3, p. 1-18. 
VOIVODIC, M. 2010. Os desafios da legitimidade em sistemas multissetoriais de governança: uma análise do Forest Stewardship Council. Dissertação de Mestrado. Programa de Pós Graduação em Ciência Ambiental. Universidade de São Paulo, São Paulo.

VOIVODIC, M. A., BEDUSCHI FILHO, L.C. 2011. Os desafios de legitimidade em sistemas multissetoriais de governança: uma análise do Forest Stewardship Council. Ambiente e Sociedade, v. 14, n. 1, p. 115-132.

WACKERNAGEL, M.; REES, W 1996. Our ecological footprint: Reducing human impact on the Earth. Gabriola Island, CA: New Society Publishers.

WANG, L., DING, X., WU, X., YU, J. 2013. Textiles industrial water footprint: methodology and study. Journal of Scientific \& Industrial Research, v. 72, p. 710-715.

WANG, L., WU, X., DING, X., NDWIGA, D. 2014. The introduction of water footprint methodology into the textile industry. Industria Textila, v. 65, n. 1, p. 33-36.

WARNER, J.F., SEBASTIAN, A.G., EMPINOTTI, V.L. 2013. Claiming (back) the land: the geopolitics of Egyptian and South African land and water grabs. Ambiente e Sociedade, v. 16, n. 2, p. 1-24.

WBCSD. WORLD BUSINESS COUNCIL FOR SUSTAINABLE DEVELOPMENT. 2013. History. Disponível em: http://www.wbcsd.org/about/history.aspx Acesso em 15/10/2013.

WBCSD WORLD BUSINESS COUNCIL FOR SUSTAINABLE DEVELOPMENT. 2014. Global Water Tool. Disponível em: http://www.wbcsd.org/work-program/sectorprojects/water/global-water-tool.aspx Acesso em: 06/03/2014.

WFN. WATER FOOTPRINT NETWORK. 2014. Sobre Water Footrpint Network. Disponível em: http://www.waterfootprint.org/?page=files/AboutWFN Acesso em: 16/03/2014.

WFN. WATER FOOTPRINT NETWORK. 2014a. About WFN. Disponível em: http://www.waterfootprint.org/?page=files/WFN-mission Acesso em: 25/04/2014.

WFN. WATER FOOTPRINT NETWORK. 2014b. Water Footprint Network. Partners. Disponível em: http://www.waterfootprint.org/?page=files/OverviewPartners Acesso em: 25/04/2014.

WICHELNS, D. 2011. Do the virtual water and water footprint perspectives enhance policy discussions? International Journal of Water Resources Development, v. 27, n. 4, p. 633-645.

WILLAARTS, B.A., GARRIDO, A., LLAMAS, M.R. 2014. Water for food security and well-being in Latin America and Caribean - Social and environmental implications for a globalized economy. New York, Routledge. 432 p.

WILLAARTS, B.A., VOLK, M., AGUILERA, P., 2012. Assessing the ecosystem services supplied by freshwater flows in Mediterranean agroecosystems. Agricultural Water Management, v. 105, p. 21-31. 
WORLD ECONOMIC FORUM. 2014. The Reshaping of the World: Consequences for Society, Politics and Businesshttp. Disponível em: www3.weforum.org/docs/AM14/WEF_AM14_Public_Report.pdf Acesso em: 04/03/2014.

WORLD RESOURCES INSTITUTE. 2014. Water: mapping, measuring and mitigatins gobal water challenges. Disponível em: http://www.wri.org/our-work/topics/water Acesso em: 16/03/2014.

WORLD WATER FORUM, 2012. Forum Syntesis - Time for solutions: Global Water Framework. Dísponível em: http://www.worldwaterforum6.org/fileadmin/user_upload/pdf/publications_elem/publications _global-water-framework_28-08-2012.pdf Acesso em: 05/05/2014.

WORLD WATER WEEK. 2014. About World Water Week in Stockholm. Disponível em: http://www.worldwaterweek.org/about Acesso em: 09/05/2014.

WSSCC. WATER SUPLY \& SANITATION COLLABORATIVE COUNCIL. 2014. Our past, present and future. Disponível em: http://www.wsscc.org/about-us/past-present-future Acesso em: 12/08/2014.

WWAP. WORLD WATER ASSESSMENT PROGRAMME. 2012. The United Nations World Water Development Report 4: Managing Water under Uncertainty and Risk. Paris, UNESCO. Disponível em: http://unesdoc.unesco.org/images/0021/002156/215644e.pdf Acesso em: 23/05/2013.

WWC. WORLD WATER COUNCIL. 2004. Analysis of the $3^{\text {rd }}$ World Water Forum. Disponível em: http://www.worldwatercouncil.org/fileadmin/world_water_council/documents/world_water_f orum_3/3d_World_Water_Forum_analysis.pdf Acesso em: 09/10/2013.

WWC. WORLD WATER COUNCIL, 2009a. Water at a Crossroad. Disponível em: http://www.worldwatercouncil.org/fileadmin/world_water_council/documents_old/World_W ater_Forum/WWF5/Water_at_a_Crossroad.pdf Acesso em: 29/04/2014.

WWC. WORLD WATER COUNCIL, 2009b. V Foro Mundial da Água - Lo más destacado de Estambul. Disponível em: http://www.worldwatercouncil.org/fileadmin/world_water_council/documents_old/World_W ater_Forum/WWF5/5th_Forum_Highlights_Spanish.pdf Acesso em: 29/04/2014.

WWC. WORLD WATER COUNCIL. 2013a. Background. Disponível em: http://www.worldwatercouncil.org/about-us/background/ Acesso em: 09/08/2013.

WWC. WORLD WATER COUNCIL. 2013b. Vision, Mission, Strategy. Disponível em: http://www.worldwatercouncil.org/about-us/vision-mission-strategy/ Acesso em: 09/08/2013.

WWC. WORLD WATER COUNCIL. 2013c. World Water Council - List of Members. Disponível em: http://www.worldwatercouncil.org/fileadmin/world_water_council/documents/wwcmembership/WWC_List-of-Members.pdf Acesso em: 10/09/2013. 
WWC. WORLD WATER COUNCIL. 2013d. $2^{\text {nd }}$ World Water Forum, The Hague, March 2000 - From Vision to Act. Disponível em: http://www.worldwatercouncil.org/forum/thehague-2000/ Acesso em: 16/09/2013.

WWC. WORLD WATER COUNCIL. 2013e. $4^{\text {th }}$ World Water Forum. Disponível em: http://www.worldwatercouncil.org/forum/mexico-2006/ Acesso em: 17/10/2013.

WWC. WORLD WATER COUNCIL. 2014. 5 World Water Forum, Istambul. Disponível em: http://www.worldwatercouncil.org/forum/istanbul-2009/ Acesso em: 28/04/2014.

WWC. WORLD WATER COUNCIL. 2014a. 6 World Water Forum, Marseille. Disponível em: http://www.worldwatercouncil.org/forum/marseille-2012/ Acesso em: 05/05/2014.

YIN, R.K. 2005. Estudo de caso: planejamento e métodos. 3. ed. Porto Alegre: Bookman,

YORK, R., ROSA, E.A. 2003. Key Challenges to Ecological Modernization Theory: Institutional Efficacy, Case Study Evidence, Units of Analysis, and the Pace of EcoEfficiency. Organizational Environment, n. 16, p. 273-288.

ZENG, Z.; LIU, J.; KOENEMAN, P.H.; ZARATE, E.; HOEKSTRA, A.Y. 2012. Assessing water footprint at river basin level: a case study for the Heihe River Basin in northwest China, Hydrology and Earth System Sciences, v.16, n.8p. 2771-2781.

ZHANG, G.P., HOEKSTRA, A.Y., MATHEWS, R.E. 2013. Water Footprint Assessment (WFA) for better water governance and sustainable development. Water Resources and Industry, v. 1-2, p.1-6.

ZHANG, C., ANADON, L. D. 2014. A multi-regional input-output analysis of domestic virtual water trade and provincial water footprint in China. Ecological Economics, v. 100, $159-172$.

ZONDERLAND-THOMASSEN, M.A.,LEDGARD, S.F. 2012. Water footprinting - A comparison of methods using New Zealand dairy farming as a case study. Agricultural Systems, v. 110, p 30-40. 


\section{Apêndice}

Quadro 3. Motivos da utilização da Pegada Hídrica extraídos dos documentos analisados (antes da categorização). Elaborado pela autora.

\begin{tabular}{|c|c|c|c|c|}
\hline \multirow{2}{*}{ Documentos } & \multirow{2}{*}{$\begin{array}{c}\text { Tipo de } \\
\text { documento }\end{array}$} & \multirow[b]{2}{*}{ Setor } & \multicolumn{2}{|c|}{ Por que usou a PH? } \\
\hline & & & $\begin{array}{l}\text { Motivos apontados } \\
\text { antes do estudo }\end{array}$ & $\begin{array}{c}\text { Motivos apontados depois do } \\
\text { estudo }\end{array}$ \\
\hline Ercin et al., 2011 & artigo & bebidas & $\begin{array}{c}\text { método mais } \\
\text { apropriado para } \\
\text { contabilizar água na } \\
\text { cadeia toda }\end{array}$ & $\begin{array}{l}\text { 1) identifica ingredientes que } \\
\text { consomem mais água para serem } \\
\text { produzidos; 2) identifica a pressão } \\
\text { nos locais onde são produzidos; } \\
\text { identifica qual fase do processo } \\
\text { consome mais água; 3) avaliar a } \\
\text { situação hídrica dos locais onde } \\
\text { ingrediente foram produzidos; }\end{array}$ \\
\hline Wang et al., 2013 & artigo & têxtil & $\begin{array}{l}\text { 1) permite conhecer } \\
\text { a pressão causada } \\
\text { aos recursos hídricos } \\
\text { de casa fase do } \\
\text { processo; 2) permite } \\
\text { comunicar } \\
\text { desempenho } \\
\text { ambiental e social } \\
\text { para stakeholders }\end{array}$ & $\begin{array}{l}\text { 1) identificar hotspots onde há } \\
\text { mais consumo de água e poluição } \\
\text { no processo industrial; 2) } \\
\text { identificar tecnologias mais } \\
\text { eficientes; aumenta consciência } \\
\text { quantitativa da pressão sobre água } \\
\text { causada pelo setor; 3) serve como } \\
\text { base para desenvolver estratégias e } \\
\text { priorizar ações para reduzir } \\
\text { consumo; 4) resulta em } \\
\text { informaçõess claras sobre } \\
\text { consumo e poluição da água por } \\
\text { produto, processo e tecnologia } \\
\text { utilizada }\end{array}$ \\
\hline Ene et al., 2013 & artigo & bebidas & $\begin{array}{c}\text { 1) permite } \\
\text { contabilizar } \\
\text { consumo e poluição } \\
\text { na cadeia de valor, } \\
\text { informações } \\
\text { importantes para a } \\
\text { gestão; } 2 \text { ) porque } \\
\text { contribui para } \\
\text { enfrentar melhor os } \\
\text { riscos relacionados à } \\
\text { água (físicos) }\end{array}$ & $\begin{array}{l}\text { 1) identifica hotspots onde há } \\
\text { maior consumo de água na cadeia, } \\
\text { identificando riscos relacionados à } \\
\text { água, permitindo melhorar a } \\
\text { gestão da água ; 2) amplia } \\
\text { conscientização para o setor } \\
\text { privado em relação à água } \\
\text { contribuindo com decisões que } \\
\text { aumentem sustentabilidade } \\
\text { ambiental; 3) ajuda a identificar } \\
\text { possíveis riscos; 4) transparencia } \\
\text { para consumidores 5) redução da } \\
\text { PH = redução de custos com } \\
\text { consumo de água (regulatorio e } \\
\text { financeiro) }\end{array}$ \\
\hline
\end{tabular}


Quadro 3. Motivos da utilização da Pegada Hídrica extraídos dos documentos analisados (antes da categorização). Elaborado pela autora. (continuação)

\begin{tabular}{|c|c|c|c|c|}
\hline \multirow[b]{2}{*}{ Documentos } & \multirow[b]{2}{*}{$\begin{array}{c}\text { Tipo de } \\
\text { documento }\end{array}$} & \multirow[b]{2}{*}{ Setor } & \multicolumn{2}{|c|}{ Por que usou a PH? } \\
\hline & & & $\begin{array}{l}\text { Motivos apontados } \\
\text { antes do estudo }\end{array}$ & $\begin{array}{l}\text { Motivos apontados depois do } \\
\text { estudo }\end{array}$ \\
\hline $\begin{array}{l}\text { Chico et al., } \\
\qquad 2013\end{array}$ & artigo & têxtil & $\begin{array}{c}\text { porque a PH considera a } \\
\text { cadeia toda diferente } \\
\text { dos métodos } \\
\text { tradicionais }\end{array}$ & $\begin{array}{l}\text { 1) identificar fase da cadeia } \\
\text { produtiva que consome mais } \\
\text { água; 2) compreender o impacto } \\
\text { de políticas públicas agrícolas } \\
\text { no uso da terra e água; } 3 \text { ) } \\
\text { estímular a eficiência no uso e } \\
\text { tratamento de efluente, pois PH } \\
\text { varia de acordo com local e } \\
\text { formas de produção }\end{array}$ \\
\hline $\begin{array}{l}\text { Ridout et al., } \\
\quad 2009\end{array}$ & artigo & alimentos & $\begin{array}{l}\text { porque a PH considera a } \\
\text { cadeia toda diferente } \\
\text { dos métodos } \\
\text { tradicionais }\end{array}$ & $\begin{array}{l}\text { 1) identificar fase da cadeia } \\
\text { produtiva que consome mais } \\
\text { água; } 2 \text { ) ter informações para } \\
\text { conversar com stakeholders e } \\
\text { impulsionar melhores práticas } \\
\text { na cadeia; 3) desenvolver } \\
\text { estratégias e priorizar ações para } \\
\text { reduzir consumo de água; 4) } \\
\text { base para avaliação de risco } \\
\text { físico na cadeia; 5) tem } \\
\text { potencial para ser usada como } \\
\text { ferramenta de comunicação 6) } \\
\text { dar visibilidade para a relação } \\
\text { entre uso da água e danos } \\
\text { socioambientais 7) produção e } \\
\text { consumo sustentaveis }\end{array}$ \\
\hline $\begin{array}{c}\text { Jefferies } \boldsymbol{e t} \\
\text { al., } 2012\end{array}$ & artigo & alimentos & $\begin{array}{c}\text { porque permite uma } \\
\text { visão mais ampla do uso } \\
\text { da água na cadeia } \\
\text { produtiva }\end{array}$ & $\begin{array}{l}\text { 1) identificar hotspots na cadeia } \\
\text { produtiva; 2) desenvolver } \\
\text { estrtatégia de resposta para } \\
\text { minimizar impactos de maneira } \\
\text { ampla e integrada; 3) aborda a } \\
\text { natureza temporal e espacial dos } \\
\text { impactos à água; 4) oferece } \\
\text { informação transparente para } \\
\text { melhorar eficiência no uso da } \\
\text { água e formular robustas } \\
\text { estratégias corporativas }\end{array}$ \\
\hline $\begin{array}{l}\text { Herath et al., } \\
\quad 2013\end{array}$ & artigo & bebidas & $\begin{array}{l}\text { 1) porque permite uma } \\
\text { visão mais ampla do uso } \\
\text { da água na cadeia } \\
\text { produtiva; } 2 \text { ) demanda } \\
\text { de consumidores }\end{array}$ & $\begin{array}{l}\text { 1) identificar fase da cadeia } \\
\text { produtiva que consome mais } \\
\text { água; 2) Cores de água: } \\
\text { instrutivas e podem servir como } \\
\text { base para avaliação de impacto } \\
\text { do uso da água na bacia ou } \\
\text { região; }\end{array}$ \\
\hline
\end{tabular}


Quadro 3. Motivos da utilização da Pegada Hídrica extraídos dos documentos analisados (antes da categorização). Elaborado pela autora. (continuação)

\begin{tabular}{|c|c|c|c|c|}
\hline \multirow[b]{2}{*}{ Documentos } & \multirow{2}{*}{$\begin{array}{c}\text { Tipo de } \\
\text { documento }\end{array}$} & \multirow[b]{2}{*}{ Setor } & \multicolumn{2}{|c|}{ Por que usou a PH? } \\
\hline & & & $\begin{array}{l}\text { Motivos apontados } \\
\text { antes do estudo }\end{array}$ & \begin{tabular}{|c|}
$\begin{array}{c}\text { Motivos apontados depois } \\
\text { do estudo }\end{array}$ \\
\end{tabular} \\
\hline $\begin{array}{l}\text { Peña; } \\
\text { Huijbregts, } \\
2013\end{array}$ & artigo & $\begin{array}{l}\text { mineração } \\
\text { (cobre) }\end{array}$ & $\begin{array}{c}\text { Porque permite } \\
\text { quantificar o uso da } \\
\text { água em toda a cadeia } \\
\text { produtiva }\end{array}$ & $\begin{array}{l}\text { 1) identificar fases do } \\
\text { processo produtivo onde } \\
\text { mais se usa água; 2) gerar } \\
\text { informações valiosas para } \\
\text { melhorar eficiência e gestão } \\
\text { da água; }\end{array}$ \\
\hline $\begin{array}{l}\text { Niccolucci } e t \\
\text { al., } 2011\end{array}$ & artigo & bebidas & $\begin{array}{l}\text { 1) porque permite uma } \\
\text { visão mais ampla do } \\
\text { uso da água na cadeia } \\
\text { produtiva; } 2 \text { ) método } \\
\text { bastante utilizado }\end{array}$ & $\begin{array}{l}\text { 1) identificar fases do } \\
\text { processo onde mais se usa } \\
\text { água; 2) estabelecer } \\
\text { relações entre eficiência e } \\
\text { características da empresa; } \\
\text { 3) verificar os efeitos das } \\
\text { políticas de redução de } \\
\text { materiais e energia; 4) } \\
\text { entender a relação água e } \\
\text { energia dentro da empresa; } \\
\text { 5) elaborar estratégias para } \\
\text { reduzir PH }\end{array}$ \\
\hline $\begin{array}{l}\text { Wang et al., } \\
2014\end{array}$ & artigo & têxtil & $\begin{array}{l}\text { 1) revela os impactos à } \\
\text { água causados pelos } \\
\text { processos industriais; } 2 \text { ) } \\
\text { pq permite identificar } \\
\text { etapas onde reduzir } \\
\text { consumo de água; } 3 \text { ) } \\
\text { potencial para apoiar } \\
\text { comunicação com } \\
\text { stakeholders }\end{array}$ & $\begin{array}{l}\text { 1) identifica fase onde há } \\
\text { mais consumo e poluição de } \\
\text { água; 2) efluente impacta } \\
\text { mais que o consumo de } \\
\text { água (PHcinza>PHazul); 3) } \\
\text { tratamento de efluentes } \\
\text { pode reduzir drasticamente } \\
\text { PH cinza }\end{array}$ \\
\hline $\begin{array}{l}\text { Ruini et al., } \\
\qquad 2013\end{array}$ & artigo & alimento & $\begin{array}{l}\text { 1) Riscos físicos, } \\
\text { regulatórios, } \\
\text { reputacionais e } \\
\text { financeiros; } \\
\text { 2) Melhor compreensão } \\
\text { das questões sobre água } \\
\text { e seus impactos; } \\
\text { 3)Produz Informações } \\
\text { úteis para empresas, } \\
\text { cadeia, governos }\end{array}$ & $\begin{array}{l}\text { 1) Identificar fases onde há } \\
\text { maior consumo de água e } \\
\text { onde é possível atuar para } \\
\text { reduzir; } \\
\text { 2) Diferença entre } \\
\text { variedades de trigo no } \\
\text { consumo de água; usar à } \\
\text { mais tolerante a escassez } \\
\text { 3) Identificar locais e } \\
\text { técnicas que influenciam no } \\
\text { consumo de água; } \\
\text { 4) Avaliação da PH ponto } \\
\text { estratégico para uma } \\
\text { empresa }\end{array}$ \\
\hline
\end{tabular}


Quadro 3. Motivos da utilização da Pegada Hídrica extraídos dos documentos analisados (antes da categorização). Elaborado pela autora. (continuação)

\begin{tabular}{|c|c|c|c|c|}
\hline \multirow[b]{2}{*}{ Documentos } & \multirow{2}{*}{$\begin{array}{c}\text { Tipo de } \\
\text { documento }\end{array}$} & \multirow[b]{2}{*}{ Setor } & \multicolumn{2}{|c|}{ Por que usou a PH? } \\
\hline & & & $\begin{array}{l}\text { Motivos apontados } \\
\text { antes do estudo }\end{array}$ & $\begin{array}{c}\text { Motivos apontados depois do } \\
\text { estudo }\end{array}$ \\
\hline $\begin{array}{c}\text { Francke; } \\
\text { Castro, 2013 }\end{array}$ & artigo & cosmético & $\begin{array}{l}\text { 1) Porque a água é uma } \\
\text { questão estratégica; } \\
\text { 2) Porque considera a } \\
\text { cadeia produtiva }\end{array}$ & $\begin{array}{l}\text { 1) Identificar fases onde há maior } \\
\text { consumo de água } \\
\text { 2) Identificar locais onde há maior } \\
\text { consumo de água; } \\
\text { 3) Promover reflexão e } \\
\text { conscientização dentro da empresa } \\
\text { em como abordar a questão da } \\
\text { sustentabilidade do uso da água }\end{array}$ \\
\hline $\begin{array}{l}\text { SABMiller; } \\
\text { WWF, } 2009\end{array}$ & relatório & bebidas & $\begin{array}{l}\text { 1) Compreender riscos } \\
\text { físicos que } \\
\text { comprometam a } \\
\text { empresa; 2) ajudar na } \\
\text { tomada de decisão 3) } \\
\text { ajuda na comunicação e } \\
\text { engajamento de } \\
\text { stakeholders }\end{array}$ & $\begin{array}{l}\text { 1) ampliar entendimento no } \\
\text { consumo de água na cadeia } \\
\text { produtiva; 2) identificar fases e } \\
\text { locais onde há mais consumo de } \\
\text { água; 3) contribuir na avaliação de } \\
\text { riscos físicos e regulatórios, } \\
\text { relacionados a custos e preços } \\
\text { futuros); 4) melhoria da } \\
\text { comunicação entre elos da cadeia e } \\
\text { estabelecimento de parcerias para } \\
\text { solucionar questões. }\end{array}$ \\
\hline $\begin{array}{l}\text { SABMiller; } \\
\text { GTZ; WWF, } \\
2010\end{array}$ & relatório & bebidas & $\begin{array}{l}\text { Compreender melhor as } \\
\text { questões -chave } \\
\text { enfrentadas pelas } \\
\text { plantas industriais do } \\
\text { estudo anterior e Peru, } \\
\text { Tanzânia e Ucrânia - } \\
\text { riscos físicos }\end{array}$ & $\begin{array}{l}\text { 1) Facilitar percepção de em que } \\
\text { fase da cadeia atuar; 2) } \\
\text { Conscientizar; 3) tentar influenciar } \\
\text { decisões em ambiente externo a } \\
\text { empresa para melhorar a gestão da } \\
\text { água }\end{array}$ \\
\hline $\begin{array}{c}\text { Chapagain; } \\
\text { Orr, 2010 }\end{array}$ & relatório & alimento & $\begin{array}{l}\text { 1) para contribuir com o } \\
\text { aprimoramento do } \\
\text { método; 2) Ter base } \\
\text { para melhorar os } \\
\text { impactos ambientais da } \\
\text { cadeia produtiva }\end{array}$ & $\begin{array}{l}\text { 1) identificar fases do processo } \\
\text { onde há maior consumo de água; } 2 \text { ) } \\
\text { identificar regiões onde há ou } \\
\text { haverá riscos de escassez de água; }\end{array}$ \\
\hline $\begin{array}{c}\text { TCCC; TNC, } \\
2010\end{array}$ & relatório & bebidas & $\begin{array}{l}\text { 1) para contribuir com o } \\
\text { aprimoramento do } \\
\text { método; 2) para } \\
\text { identificar em quais } \\
\text { fases da cadeia } \\
\text { produtiva esforços } \\
\text { devem ser direcionados }\end{array}$ & $\begin{array}{l}\text { 1) identificar fases do processo } \\
\text { onde há maior consumo de água; } 2 \text { ) } \\
\text { melhorar o conhecimento interno } \\
\text { sobre uso da água; } 3 \text { ) facilitar } \\
\text { comunicação entre stakeholders } \\
\text { sobre água }\end{array}$ \\
\hline
\end{tabular}


Quadro 3. Motivos da utilização da Pegada Hídrica extraídos dos documentos analisados (antes da categorização). Elaborado pela autora. (continuação)

\begin{tabular}{|c|c|c|c|c|}
\hline \multirow[b]{2}{*}{ Documentos } & \multirow{2}{*}{$\begin{array}{c}\text { Tipo de } \\
\text { documento }\end{array}$} & \multirow[b]{2}{*}{ Setor } & \multicolumn{2}{|c|}{ Por que usou a PH? } \\
\hline & & & $\begin{array}{l}\text { Motivos apontados } \\
\text { antes do estudo }\end{array}$ & $\begin{array}{c}\text { Motivos apontados depois } \\
\text { do estudo }\end{array}$ \\
\hline $\begin{array}{c}\text { IFC; } \\
\text { LimnoTech; } \\
\text { Jain Irrigation } \\
\text { Systems; TNC, } \\
\mathbf{2 0 1 0}\end{array}$ & relatório & alimento & $\begin{array}{l}\text { 1) compreender uso da } \\
\text { água no seu processo } \\
\text { produtivo; } 2 \text { ) enfrentar } \\
\text { riscos de escassez; } 3 \text { ) } \\
\text { ganhar destaque pelo } \\
\text { pioneirismo }\end{array}$ & $\begin{array}{l}\text { 1) identificar fases do } \\
\text { processo onde há maior } \\
\text { consumo de água; 2) } \\
\text { identificar técnica de } \\
\text { irrigação mais eficiente; 3) } \\
\text { identificar consumo de água } \\
\text { por fonte superficial e } \\
\text { subterrânea; }\end{array}$ \\
\hline $\begin{array}{c}\text { UPM- } \\
\text { Kymmene, } \\
2011\end{array}$ & relatório & papel & $\begin{array}{l}\text { 1) para contribuir com o } \\
\text { aprimoramento do } \\
\text { método; 2) para } \\
\text { melhorar a } \\
\text { compreensão sobre } \\
\text { consumo de água na } \\
\text { cadeia produtiva; } 3 \text { ) } \\
\text { melhorar tomada de } \\
\text { decisão }\end{array}$ & $\begin{array}{l}\text { 1) identificar fases do } \\
\text { processo onde há maior } \\
\text { consumo de água; 2) } \\
\text { mapear riscos físicos } \\
\text { relacionados à água e } \\
\text { oportunidades; 3) faciltar } \\
\text { comunicação com } \\
\text { fornecedores para diminuir } \\
\text { consumo de água; }\end{array}$ \\
\hline $\begin{array}{c}\text { Coca Cola } \\
\text { Europe, } 2011\end{array}$ & relatório & bebidas & $\begin{array}{l}\text { extender o olhar em } \\
\text { relação ao uso da água } \\
\text { na cadeia produtiva; } \\
\text { neste caso, calcular a } \\
\text { PH do principal } \\
\text { ingrediente: açucar } \\
\text { (continuando estudo } \\
\text { iniciado em 2010) }\end{array}$ & $\begin{array}{l}\text { 1) colaborar e fortalecer o } \\
\text { engajamento entre } \\
\text { diferentes atores e setores; } \\
\text { 2) permitir visão mais } \\
\text { ampla sobre as questões } \\
\text { relacionadas à água, não } \\
\text { percebidas com o uso do } \\
\text { método tradicional }\end{array}$ \\
\hline Sikirika, 2011 & relatório & alimento & $\begin{array}{l}\text { 1) Obter informações de } \\
\text { consumo de água na } \\
\text { cadeia produtiva }\end{array}$ & $\begin{array}{l}\text { 1) identificar qual produto } \\
\text { consome mais água; } 2 \text { ) } \\
\text { identificar qual sistema de } \\
\text { cultivo é mais intensivo no } \\
\text { consumo da água }\end{array}$ \\
\hline
\end{tabular}


Quadro 3. Motivos da utilização da Pegada Hídrica extraídos dos documentos analisados (antes da categorização). Elaborado pela autora. (continuação)

\begin{tabular}{|c|c|c|c|c|}
\hline \multirow[b]{2}{*}{ Documentos } & \multirow{2}{*}{$\begin{array}{c}\text { Tipo de } \\
\text { documento }\end{array}$} & \multirow[b]{2}{*}{ Setor } & \multicolumn{2}{|c|}{ Por que usou a PH? } \\
\hline & & & $\begin{array}{l}\text { Motivos apontados } \\
\text { antes do estudo }\end{array}$ & $\begin{array}{c}\text { Motivos apontados } \\
\text { depois do estudo }\end{array}$ \\
\hline $\begin{array}{c}\text { Unger et al., } \\
2013\end{array}$ & relatório & $\begin{array}{c}\text { químico, } \\
\text { automobilístico, } \\
\text { siderurgia, } \\
\text { energia }\end{array}$ & $\begin{array}{l}\text { 1) Prover uma análise } \\
\text { detalhada do consumo } \\
\text { e poluição da água na } \\
\text { cadeia produtiva que } \\
\text { outros métodos } \\
\text { tradicionais não } \\
\text { permitem; } 2 \text { ) método } \\
\text { reconhecido; } 3 \text { ) } \\
\text { responder aos desafios } \\
\text { em relação à água: } \\
\text { aumento da demanda, } \\
\text { mudanças climáticas }\end{array}$ & $\begin{array}{l}\text { 1) identificar consumo e } \\
\text { poluição da água em cada } \\
\text { fase do processo } \\
\text { produtivo; 2) } \\
\text { compreender a } \\
\text { vulnerabilidade de cada } \\
\text { planta à escassez de água } \\
\text { e diminuição de sua } \\
\text { qualidade; 3) envolver } \\
\text { funcionários sobre a } \\
\text { questão da água; 4) } \\
\text { identificar prioridades de } \\
\text { redução da PH por meio } \\
\text { de custos da água; 5) } \\
\text { servir como um indicador } \\
\text { de performance para si } \\
\text { mesma; } 6 \text { ) facilitador de } \\
\text { comunicação entre os } \\
\text { elos da cadeia }\end{array}$ \\
\hline $\begin{array}{c}\text { Francke; } \\
\text { Mathews, } \\
\text { 2013a }\end{array}$ & relatório & têxtil & $\begin{array}{l}\text { 1) responder às } \\
\text { preocupações em } \\
\text { relação aos impactos } \\
\text { do setor à água; 2) } \\
\text { compreender consumo } \\
\text { de água na cadeia } \\
\text { produtiva e torná-lo } \\
\text { sustentável; 3) método } \\
\text { internacionalmente } \\
\text { reconhecido }\end{array}$ & $\begin{array}{l}\text { 1) identificar hotspots de } \\
\text { consumo d eágua na } \\
\text { cadeia produtiva (fase da } \\
\text { cadeia e local); 2) } \\
\text { identificar em quais fases } \\
\text { e locais se deve atuar (em } \\
\text { função da situaão hídrica } \\
\text { da região) }\end{array}$ \\
\hline $\begin{array}{c}\text { Francke; } \\
\text { Mathews, } \\
\text { 2013b }\end{array}$ & relatório & têxtil & $\begin{array}{l}\text { 1) continuação do } \\
\text { estudo; } 2 \text { ) entender } \\
\text { impactos em termos de } \\
\text { poluição da água } \\
\text { causados por dois tipos } \\
\text { de cultivo de algodão }\end{array}$ & $\begin{array}{l}\text { identificar qual tipo de } \\
\text { cultivo causa menos } \\
\text { impacto na qualidade da } \\
\text { água (orgânico x } \\
\text { convencional) }\end{array}$ \\
\hline
\end{tabular}

